Historic, archived document

Do not assume content reflects current scientific knowledge, policies, or practices. 






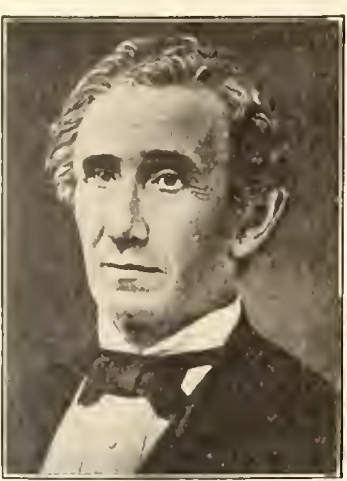

Five Generations

in the Seed

Business

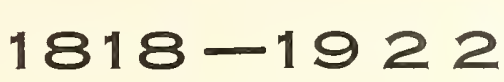

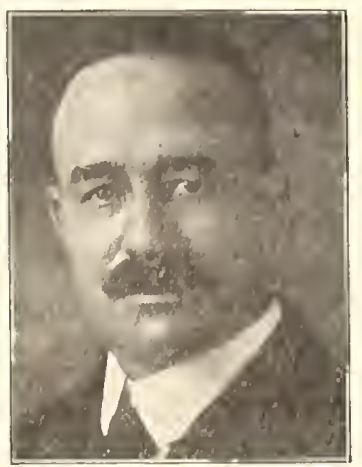

FRANK W. BOIGIANO President

Dear Folks:

In no line of human endeavor is the accumulated experience acquired with the passing years of more value than in the growing and distributing of seeds. It was in 1818 that Samuel Ault, my great grandfather, made his first small beginning in the seed business. After him came John Bolgiano my grandfather and Joseph A. Bolgiano my father, all having one object in life, which was to make the house of Bolgiano the leaders in the seed business. Known from coast to coast, from north to south, in Europe, Africa, Asia and South America and the islands of the sea, the ambition of my forefathers has been realized.

During the war period, my fellow seedsmen urged me to accept the presidency of the American Seed Trade Association which 1 did for two years, feeling that this position was a patriotic duty to my Country. When other businesses were being regulated, the Department of Agriculture, seeing the vast importance of our business, were almost in constant conference with me to stimulate the production and conservation of food. I was requested to act for one dollar per year by the Secretary of Agriculture in an advisory position. Believe me when 1 tell you 1 had all of a man's job. The results speak for themselves.

But I am not willing to stop there. I have devoted a life time to the work, starting as a boy on a farm and continuing through various trials and hardships until the present time, with but one idea always and ever present at all times, Bolgiano's "Seeds that Succeed." I have associated with me, men trained in every department as specialists so as to have their valued advice. Then, 1 have given my son Charles W. Bolgiano, a very special training for the future continuance of the large business already built up; starting at the public school, going to the Agriculture School of Cornell University, spending one season on the Experimental grounds of the Department of Agriculture and then four years on the largest Seed Farms of America, North, East and West.

It is this constant attention which has been spent for five generations and which continues on today with ever increasing vigilance, that recommends Bolgiano"s "Seeds That Succeed" to truckers, market gardeners and home gardeners. Indeed it has not been the ambition of any Bolgiano to make money solely, but rather to select and grow for you the very best. For over one hundred years Grandfathers, Fathers and Sons have planted

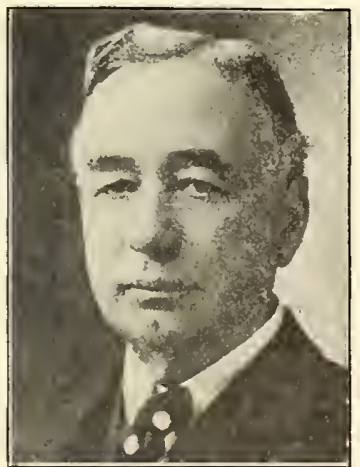

JOSEPH BOIGTANO
Bolgiano's seeds with the very best of success. lt is with this record that we solicit your seed orders for 1922, and we assure you the same careful and prompt attention as if you were here in person giving your order over our counter.

Cordially yours,

FRANK W. BOLGIANO, or Mister B.

P. S.-The only members of the Bolgiano family in the seed business are now located in Washington.

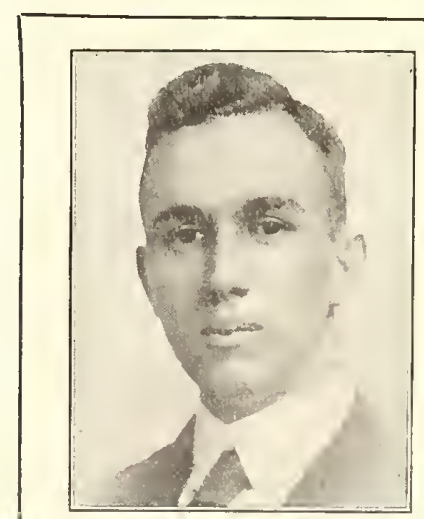

CHAS. W. BOLGIANO Vice-President 


\section{HOW TO ORDER}

FREE DELIVERY. Packets, Ounces, Quarter-Pounds, or pounds, ordered at list prices, will be sent FREE by mail or exuress. This DOES NOT APPLY to Beans, Corn, Peas, Field and Grass Seeds and Seed Potatoes, which will be sent at regular Parcel Post or Express Rates. Orders for greater than one-pound lots will also be delivered at regular parcel post or express rates.

OUR TERMS are always cash with order, or satisfactory New rork, Phildelphia, or Washington reference.

MONEY can be sent at our risk by Post-Office or Express Money Order, New York or Chicago Draft, or by registered letter. We cannot hold ourselres responsible for cash sent loose in letters.

AN ORDER BLANK for your convenience in placing your order will be found on the last page of this catalog.

NAME AND ADDRESS should be witten plainly both on the Order Blank and on the envelope enclosing the order. Names of seeds and plants should be written out in full in plain writing.

EXPRESS or FREIGHT shipments should have the name of the station plainly given where different from the post-office.

GIVE FULL DIRECTIONS almays whether shipment is male by freight, express or Parcel Post.

ORDER EARLY, for although we aim to till all orders within twenty-four hours after receipt, unavoidable circumstances sometimes causes delay.
WE GUARANTEE our seeds, plants, etc., to reach our customer in good condition. We give no warranty, expressed or implied, as to description, purity of productiveness, or any other matter of any seeds, plants or bulbs we send out, and will not be in any way responsible for the crop. If purchaser does not accept the goods on these terms, they are to be returned to once, and the money that has been paid for same will be refunded. There are many reasons why seeds do not always turn out as desired such as sowing too deep or too shallow, in too wet weather, cold weather or too dry soil, or too wet soil, insects which do not only destroy the seeds, but often the young plants, about the time they appear at the surface of the ground. For these causes we cannot guarantee seeds or the crop.

We Will Pay War Tax on Parcel Post Packages. As a courtesy to our customers and as an appreciation of their trade, we will pay the new war tax on all Parcel Post packages ordered from us.

\section{SIZE OF PARCEL THAT CAN BE SENT BY PARCEL POST}

Size of package that can be sent by Parcel Post cannot be over 84 inches in length and girth combined.

The rate of postage on mailable parcels of seeds, cuttings, bulbs, roots and plants weighing 8 ounces or less, shall be 1c for each 2 ounces or fraction thereof, regardless of distance, and on those weighing more than 8 ounces the pound rates shown in table shall apply.

\section{WEIGHTS BY PARCEL POST}

Parcels up to 70 pounds can be sent by Parcel Post in the local, 1st, 2nd and $3 \mathrm{rd}$ zones, and up to 50 pounds in all other zones.

To points further than the 2nd zone on weight of over 10 pounds, the charge by freight or express is usually more economical.

\section{United States Parcel Post Rates-Fourth-Class Matter Seeds, Plants, Bulbs, Roots, Garden, Lawn and Poultry Supplies}

\section{RATE TABLE}

Local Rate Washington and Suburbs only...

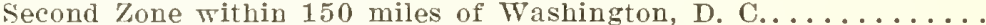

Third Zone within 300 miles of Washington, D. C...........

Fourth Zone within 600 miles of Washington, D. C............

Fifth Zone within 1,000 miles of Washington, D. C............

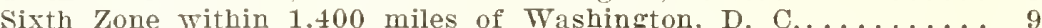

Serenth Zone within 1,800 miles of Washington, D. C.........11c

Eighth Zone all огеr 1,800 miles from Washington, D. C........ 12c
First Zone within 50 miles of Washington, $\mathrm{D} . \mathrm{C} . \ldots \ldots \ldots \ldots \ldots \ldots$

$\begin{array}{cc}\begin{array}{c}\text { First } \\ \text { Lb. or } \\ \text { Fraction }\end{array} & \begin{array}{c}\text { Each addi- } \\ \text { tional lb. or } \\ \text { Fraction }\end{array} \\ 5 c & 1 / 2 \mathrm{c} \\ 5 \mathrm{c} & 1 \mathrm{c} \\ 5 \mathrm{c} & 1 \mathrm{c} \\ 6 \mathrm{c} & 2 \mathrm{c} \\ 7 \mathrm{c} & 4 \mathrm{c} \\ 8 \mathrm{c} & 6 \mathrm{c} \\ 9 \mathrm{c} & 8 \mathrm{c} \\ 11 \mathrm{c} & 10 \mathrm{c} \\ 12 \mathrm{c} & 12 \mathrm{c}\end{array}$

\section{N D E X}

\begin{tabular}{|c|c|c|c|c|}
\hline Page & Page & & Page & \\
\hline VEGETABLES & Chicory ........15 & Iangel-Wurzel ....11 & Salsify . . . . . 35 & Dahlias .....54 \\
\hline 1 Collections .41 & ards $\ldots . . .9 .19$ & $\begin{array}{l}\ldots 26 \\
\ldots 25\end{array}$ & $c_{\ldots} \ldots \ldots \ldots 35$ & Summer Bull \\
\hline . & Corn Salad .......15 & 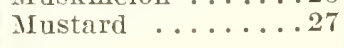 & .11 & Sweet Peas \\
\hline iragus . . & $\begin{array}{l}\text { Cress } \ldots . . . . . \\
\text { Cucumber } \ldots . .\end{array}$ & $\begin{array}{l}\text { Onion } \ldots \ldots \ldots \ldots 27 \\
\text { Okra } \ldots \ldots \ldots \ldots 28\end{array}$ & ${ }_{0} \ldots \ldots \ldots$ & \\
\hline $\begin{array}{l}\text { eans } \ldots \ldots \ldots .7 \\
\text { eets } \ldots .11 \\
\end{array}$ & 21 & Parsley ........2s & $\cdots 40$ & \\
\hline & 19 & .28 & .26 & ( \\
\hline & bs $\ldots$ & $\cdots 28$ & $12-43$ & ERS ...77 \\
\hline age plants.....1 & & & -55 & $5.78-79$ \\
\hline . & & & as & $.66 \cdot 76$ \\
\hline & ce & & turtiums & 5 \\
\hline
\end{tabular}




\section{NOVELTIES AND SPECIALTIES}

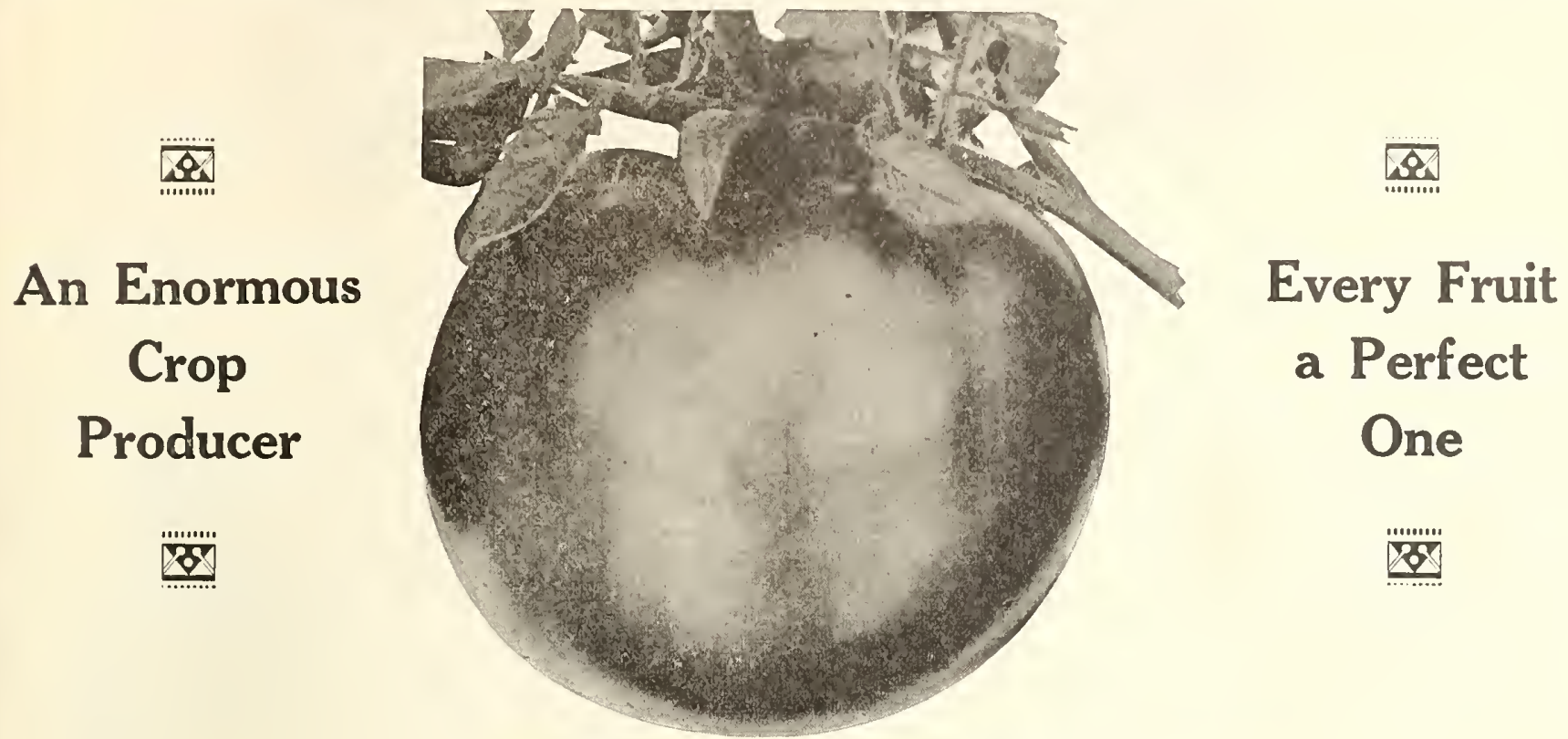

\section{Bolgiano's Capitol Tomato}

In naming the New Tomato we could find no name that would better suggest its leadership.

Has now been tried out by tomato growers in every state in the Union, and many of the foreign countries. The reports we have received have been full of praise and appreciation of its wonderful good qualities. The color is a brilliant red fruit, firm, solid and meaty. Perfectly smooth. Ripens right up to the stem end. Almost as early as the Earliana. Free from core. Flavor mild. Produces heavy crops of fine fruit, when some of the other varieties are complete failures.

We urge you to mail us your order immediately. You will be delighted with your crop and receive big profits.

Pkt. 25 cts.; $1 / 2$ oz. $\$ 1.25 ;$ oz. $\$ 2.25 ; \quad 1 / 4$ lb. $\$ 7.50$; lb. $\$ 25.00$.

\section{Bolgiano's Red Cross Tomato. This Blight re-} sisting Tomato proved to be the best resister from diseases that has been introduced for many years. We worked incessantly to develop and verfect this much-needed variety, and today thousands of tomato growers, market gardeners and home gardeners are unanimous in pronouncing the "Red Cross" a perfect, healthy, vigorous grower all during the season. Vines are just loaded with beautiful deep red solid toma. toes. Perfectly smooth, very small core, flavor mild and refreshing. No watery seed cavities, just a solid mass of meaty flesh. The strong vitality of the plant makes it a heary yielder from early midsummer until late frost. Your harvest will be sure when planting the Red Cross tomato. Order immediately the seed you will need. Pkt. 10 cts.; oz. 75 cts.; $1 / 4$ ib. $\$ 2.75 ;$ ib. $\$ 10.00$.

212. John Baer Tomato. The best early tomato on earth when planted in good rich soil. We have been reselecting our secd from the originator's stock: its earliness and perfectness has been improved and the size is much larger. This perfect solid, meaty, brilliant red tomato has no cripples. No scar on blossom end. No cracks on the high crown stem end. Just one solid perfect fruit. John Baer tomato has a mild sweet flavor, the finest you have ever tasted. Our supply of seed this vear is small. Let us have your order early. Pkt. 10 cts.; oz. 75 cts.; $1 / 4$ lb. $\$ 2.25 ;$ lb. $\$ 8.00$.
67. Bolgiano's "Crimson Cropper" Tomato. We are constantly to bring out better quality and types of vegetables for our customers and friends. We have in the "Crimson Cropper" succeeded in pleasing thousands of growers that have planted this tomato. Its many good qualities combined with earliness have made it a winner. The vigorous growth of vines protects the enormous crop of fruit from sun burns and scores. This large solid beautiful red tomato will please any grower. You must order early to obtain your supply of seed. Pkt. 10 and 25 cts.; oz. $\$ 1.50 ; \quad r / 4$ lb. $\$ 5.00 ; \quad$ lb. $\$ 15.00$.

Bolgiano Tomato. We accept no credit in the creating of this glorious Tomato. Nature with her wonderful activities has produced this wonder of the tomato family. Blossoms continually; every vine is just loaded with perfect red solid tomatoes all during the season. The Bolgiano Tomato is two weeks earlier than Earliana. First fruit just as perfect as the prime fruit of the season. The heavy potato leaf foliage protects the fruit from sun scalds and blisters. The large stem set clusters make it a profitable tomato for the grower. Never have we received such acknowledgments from any of our own creations as we have the "Bolgiano" tomato. Indeed it meets every requirement to make it the best market shipping and canning tomato that has been grown. You must order quick if you want some of this seed. Pkt. 25 cts.; $1 / 2$ oz. \$1.25; oz. $\$ 2.25 ; \quad 1 / 4$ lb. $\$ 7.50 ;$ lb. $\$ 25.00$.

Bolgiano's Glory Tomato. S t a n d s all weather and climate conditions better than most varieties, and has made many friends with the tomato growers, who spenk in the following terms: "No tomato equal to it," "has great values for both market and canning," "outgrows and outsells any tomato on the marliet," "by far the best ever grown," "did best of all," "prefer it to all others," "lives and bears abundantly when other varieties die," "vines keep vigorous and bear beatiful solid red tomatoes until frost.' We cannot say more for the Glory. The growers have given you its true value. Place your order at once for the seed rou will need. Pkt. 10 and 25 cts.; oz. $\$ 1.50 ; \quad 1 / 4$ lb. $\$ 5.00 ; 1 b . \$ 15.00$. 


\section{NOVELTIES AND SPECIALTIES-Continued}

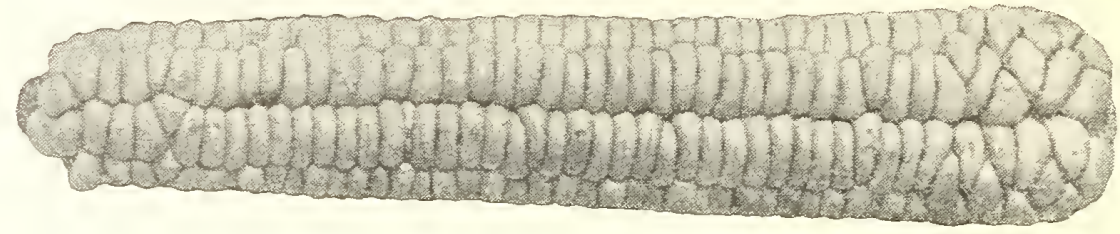

Bolgiano's Extra Early "Harvester" Sugar Corn.

\section{Bolgiano's Extra Early "Harvester" Sugar Corn.}

This is the earliest white Sugar Corn that has erer been placed on the market. For many rears the home gardeners hare been anxious for a White Corn that would be as early and as sweet as the "Golden Bantam." Bolgiano's Extra Early "Harvester" Sugar Coru has been thoroughly tested and tried side by side with all other extra early rarieties. It is several days earlier than the "Golden Bantam." Sweet flaror; ears larger aud pure white in color. Cau be grown in most any section of the United States; rapid grower, enormous vielder. It is a wonderful corn to grow for earls home use. Pkt. 10 cts.; pt. 25 cts.; qt. 45 cts.; peck, $\$ 2.85$; bushel, $\$ 10.50$.

Bolgiano's Extra Early Ideal Sweet Corn. We h a r e out any corn that has giren more satisfaction to the market gardener thau the "Ideal"; it meets his erery demand. Extra early, large ears, 8 to 10 iuches long; has a mild sweet flavor; rery tender; rigorous grower, producing a wonderful crop of corn for the early market. Cau be planted as early as the Extra Early Adams. Thousands of truckers and market gardeners are now using the "Ideal" for their early planting. Pkt. 10 cts.; pt. 20 cts.; qt. 35 cts.; peck, $\$ 1.75$; bushel, $\$ 6.00$.

\section{Bolgiano's French Golden Self-Blanching Celery.}

We hare positively refused to sell any self-blanching celery except oul French grown stock, Which me know is superiol in quality and the most economical to grow. It is a rigorous dwarf grower, compact and self-blanching to a rery remarkable degree. Even the ribs become a handsome. fresh, clear yellow color, with a heart that is large and solid and of a beautiful rich golden yellow. Its crispness and teuderness and its rich nutty flavor makes it the leading variety in the market. We waut you to see with your own ejes, in rour own fields, that Bolgiano's French Golden Self-Blanching Celery is the best. Place your order at once. Pkt. 10 cts.; oz. 70 cts.; I/4 Ib. \$2.25; lb. \$8.00.

\section{Bolgiano's Easy Blanching Celery. This spleudid} excells in quality, in earliuess, in quick blanching. Erer. stalk is solid, crisp, with shallow ribs and excellent flaror: the plant is medium height. rigorous grower. and blanches up with a beautiful golden heart. We advise celery growers to plant Bolgiano's Easy Blanching Celery. It is the longest keeping variety known. Will supply the Thanksgiring table, Christmas and all through the season. Send us jour order for your full supply. Pkt. 5 and 10 cts.; oz. 35 cts.; I/4 lb. $\$ 1.15 ;$ Ib. $\$ 3.50$.

\section{Bolgiano's Early Fortune Cucumber. Is truly a} introduction that has been tried and tested for more than ten years; each sear it has proven to be the best early white spine cucumber the market gardeners and truckers could grow. The dark green color remains fresh looking for dass aftel heing harvested; Haror delicate and refreshing, entirely free from any bitterness; flesh fine grained and compact. crisp and brittle, an ideal sliciug cucumber. As a shipper Early Fortune cannot be surpassed. Our stock is from the best selection. Let us supply you. Pkt. 5 and 10 cts.; 15 cts.; I/4 lb. 30 cts.; lb. $\$ 1.00$.

\section{Bolgiano's Arlington White Spine Cucumber.}

Our selected stock of this famous cucumber is by far the best type that can be grown. We select seed from only perfect cucumbers. Dark, rich green color, uniform in size. firmness, considering erery quality that is necessary to make a profitable cucumber for the gromers. As a shipper it has fer equals and is unsurpassed for home use. The Arlington White Spine is sure to make trade for the market gardener and trucker. We can supply all early orders. Pkt. 5 and 10 cts.; 0 z. 15 cts.; $1 / 4$ lb. 30 cts.; lb. $\$ 1.00$.

\section{Sweet Air Cantaloupe. This Tonderful melon is} that was erer introduced. It is the biggest money make flesh with small seed carities, delicious sweet flaror, perfectly tender; it fairly melts in rour mouth. Just the kind market buyers and shippers will pay the highest prices for. Vigorous grower, rines lieep greeu aud produce big crops of beautiful netted melons. No culls. It will please the most critical grower. Pkt. 5 and 10 cts.; oz. 15 cts.; 1/4 lb. 45 cts.; lb. $\$ 1.50$.

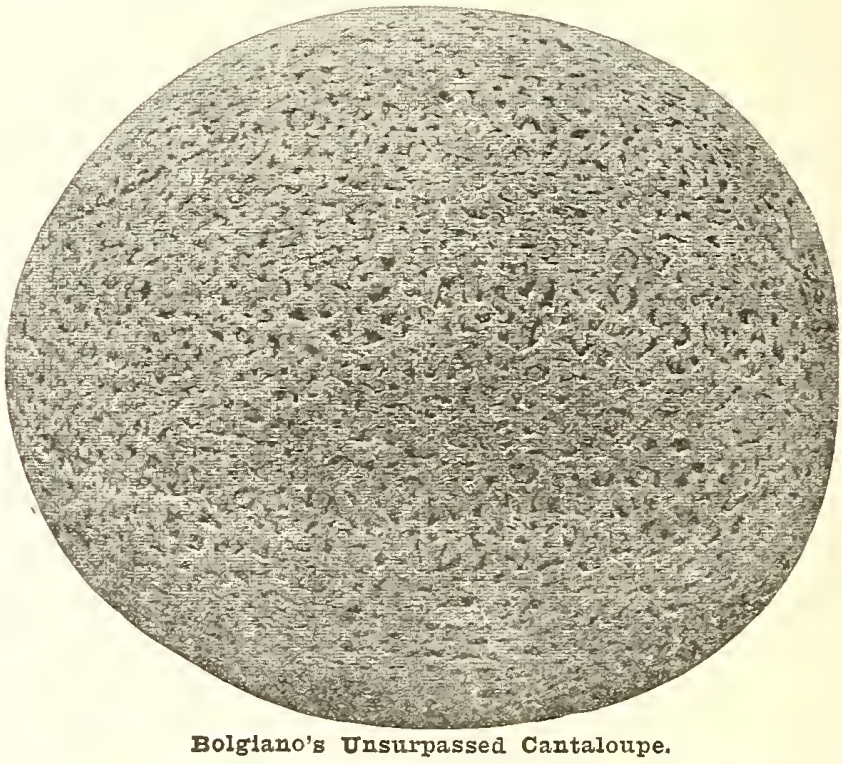

Bolgiano's Unsurpassed Cantaloupe. This melon was o $r$ i g inated in Colorado. the home of Cantaloupe growing, and has nerer been surpassed in quality by any other variety. The largest gromers throughout the country hare selected this melon for their main crop. It is a great money maker. As a shipper it is a wonder, stands long distance hauls, and is in perfect condition when shipped from California to New York. Packs 45 to the crate perfectly. "Solid netted, of a whitish gray color." The meat is a beautiful golden. Tery thick flesh with extremely small seed carities. Tender, a sweet pleasing flavor, one nerer to be forgotten. Vigorous grower. one of the best blight-resisters, producing large crops of eren size melons, absolutely no culls. Be sure and gire it a trial. Pkt. 5 and $10 \mathrm{cts}$; 0z. $30 \mathrm{cts.;}$ I/4 Ib. $\$ 1.00 ;$ ib. $\$ 3.50$. 


\section{NOVELTIES AND SPECIALTIES-Continued}

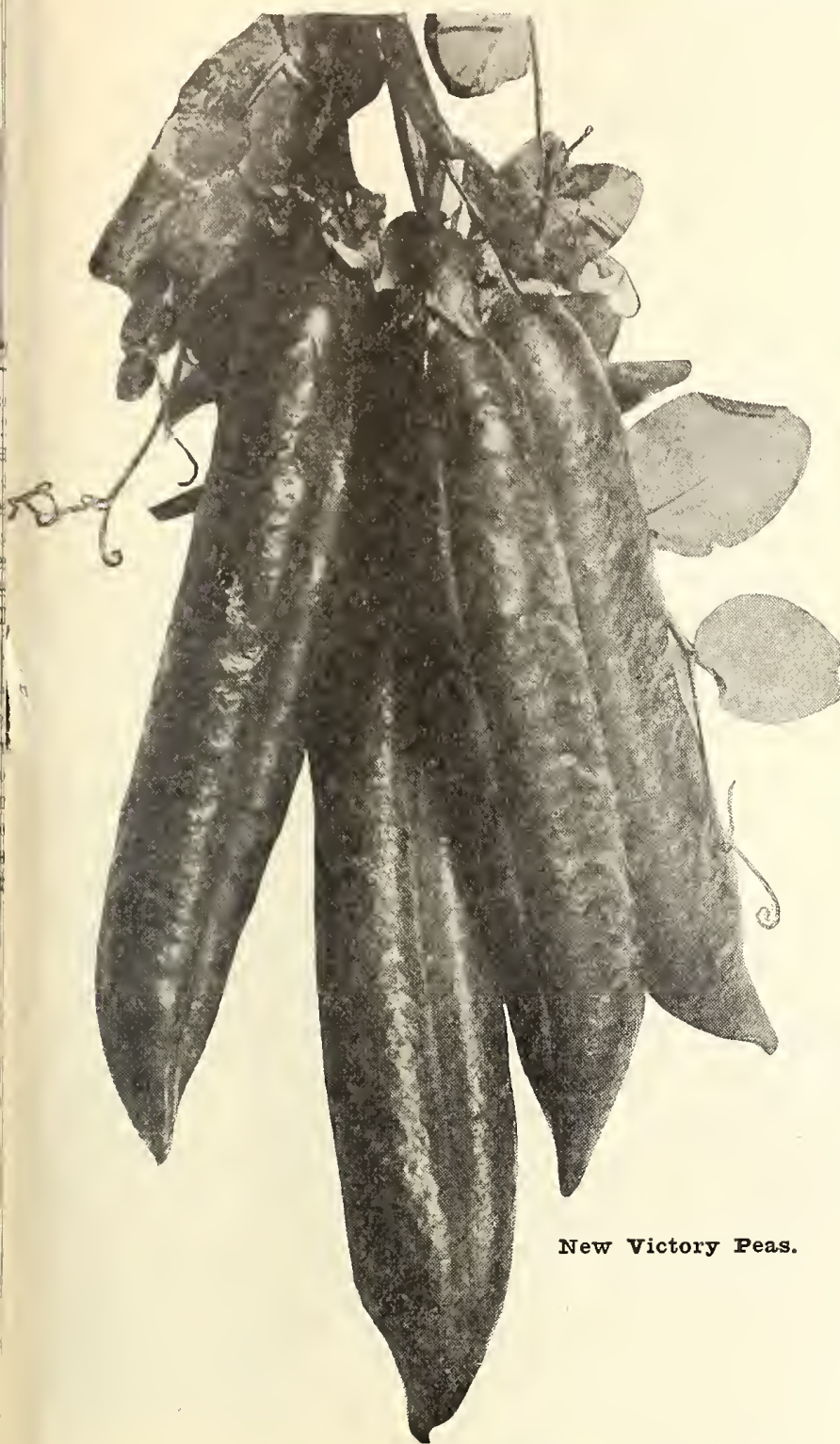

Bolgiano's New Victory Pea. Market gardeners a 11 over the country have been very anxious to obtain a large podded pea that would hold its deep green color several days after picking. Bolgiano's "Victory" Pea has all the good qualities that will meet every demand of the most critical grower and consumer. The healthy vines grow 48 inches high, producing enormous crops of beautiful large dark green pods, 5 to 6 inches long, filled. with large green peas, tender, and the fine delicious flavor makes it a favorite with all growers. We unhesitatingly recommend the "Victory." You should place your order at once. Pkt. 10 cts.; pt. 35 cts.; qt. 60 cts.; peck, $\$ 3.55$; bushel, $\$ 12.50$.

Bolgiano's Earliest Springtime. Is the earliest of all ies. Can be planted the same time as Extra Early Alaska. The pods are 4 to 5 inches long. Peas nearly as large as the Gradus. It is truly a leader in earliness, in flavor, in size of pods, in productiveness of large pods filled full of large and most delicious peas. Its vigor and regularity in growth. Its qualities make it the superior pea for the market gardener, and the pleasure the home gardener antici- pates in supplying his table with the first picking of the most delicious peas is quickly realized after planting the "Springtime." Order early to be certain of securing your supply. Pkt. 10 cts.; pt. 30 cts.; qt. 50 cts.; peck, $\$ 3.50$; bushel, \$12.00.

Bolgiano's "Early Bird"' Pea. This wonderful n e w variety can be planted as soon as the sround They do not rot in the ground like fully wrinkled peas. The dwarf vigorous vines measure 18 inches and carry enormous crops of large beantiful (leep green pods, 4 to 5 inches long, and are filled with 9 to 10 large blue marrow peas of fine flavor. Bolgiano's "Larly Bird" Pea is a profltable variety for the market gardener. For the hame gardener it is unsurpassed. Supply of seed is limited. Send your orders early. Pkt. 10 cts.; pt. 35 cts.; qt. 60 cts.; peck, $\$ 3.50$; bushel, $\$ 12.50$.

Bolgiano's Stringless Green Pod Bean. This superior b e a $n$ h a $s$ been carefully selected and grown to satisfy the most critieal grower. The long round fleshy pods, 5 to 6 inches long, are brittle and tender. Delicious flavor, absolutely stringless. Produces big crops of perfect green pod beans. It is indeed a great pleasure to offer you this wonderful bean. We know it will please you. Let us have your order early. Pkt. 10 cts.; pt. 25 cts.; qt. 40 cts.; pk. \$2.50; bus. \$9.

Bolgiano's New Wax Bean. This new round meaty golden yellow bean is the finest we have ever introduced. The plant is of an erect bushy habit, 18 to 20 inches high. Pods are brittle, absolutely stringless, without fiber, free from rust and blight. Its tender and delicious flavor has attracted not only the market gardener but the home gardener as well. You cannot afford to miss planting some of these beans. Order immediately. Pkt. 10 cts.; pt. 25 cts.; qt. 40 cts.; peck, $\$ 2.50$; bushel, $\$ 9.00$.

45. Wonderful Early Spring Beet. IIas now been given a trial by all the leading market gardeners. They are wild in their praise of its wonderfully good qualities, and speak in the following terms: "Planted side by side with other varieties, same kind of land, pulled early spring, five days before any other," "best early beet known," "perfectly smoucn and tender, delicious sweet flavor, first on the market." We are pleased in getting these reports and want you to profit in growing this beet. Pkt. 5 and $10 \mathrm{cts} . ; 0 z .15 \mathrm{cts}$.; $1 / 4 \mathrm{lb}$. 45 cts.; lb. $\$ 1.50$.

C57. Bolgiano's Extra Early Superb Beet. A splendid ety for market gardeners. The flesh is a rich dark blood red. Small tap root, perfectly smooth, crisp, tender and deliciously sweet. We can certainly recommend it with pleasure as being the most uniform in both color and shape, and it remains nice and tender to the last beet. If you wish to plant a good Beet. try it. Pkt. 5 and 10 cts.; oz. 15 cts.; 1/4 lb. 30 cts.; lb. \$1.00.

Bolgiano's New "Square Deal" Cabbage. Without a ception, Bolgiano's New" "Square Deal" Cabbage is the Biggest Money Making Cabbage ever offered the American Trucker. This is a strong assertion-at least 100,000 people will read it, so you can readily see we could not afford to make such a statement unless we were sure of our ground. The "Square Deal" Cabbage matures immediately after New Leader Cabbage. It is absolutely a "Square Deal," as we have seen ten-acre fields without a single irregular bead. The uniform heads are of excellent size for shipping, larger than the New Leader and yet not so large as to be unwieldy. The color is a fine fresh green and is retained during long shipments. For a fine Solid, Tender, Uniform, Early Flat Cabbage, Bolgiano's New "Square Deal" Cabbage challenges the world: Pkt. 5 and 10 cts.; $0 z .25$ cts.; 1/4 lb. 85 cts.; lb. $\$ 3.00$. 


\section{NOVELTIES AND SPECIALTIES-Continued}

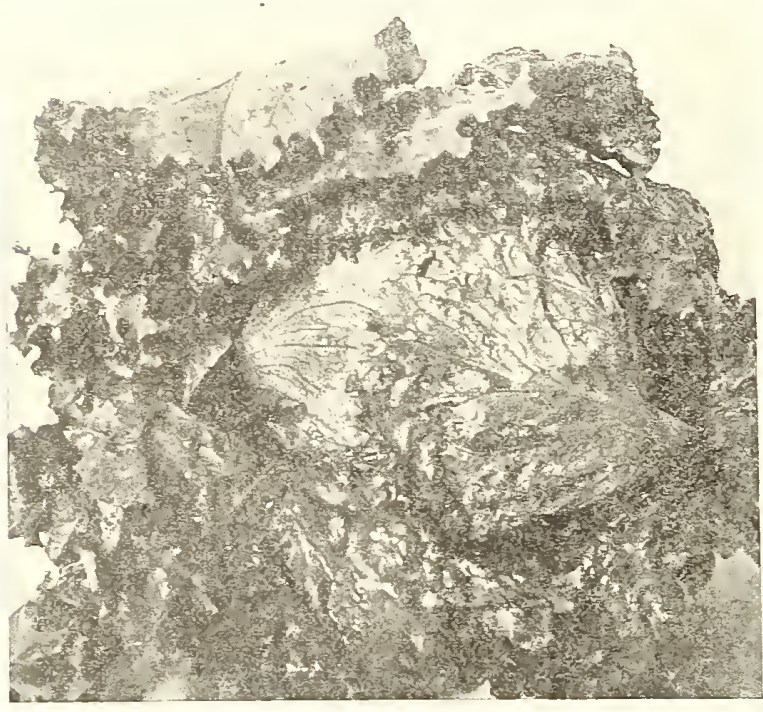

Bolgiano's IIasterpiece Iettuce.

A225. Bolgiano's "Masterpiece" Lettuce. M a r k e t and lettuce growers all orer the country are now growing the "Masterpiece" for their late spring, summer and early fall crops. No matter how hot or how long it remains in the garden it will keep crisp, tender and sweet. No bitterness. It will not go to seed quickly. Sure header, can be grown in open ground after danger of frost is over, all during the summer and early fall. Nerer spots or turns dark in any part. Will stand shipping to ans part of the United States and remain as crisp as ice. Fon will find it a profitable variety to grow. Send sour order to us immediately. Pkt. 5 and 10 cts.; 0z. 45 cts.; $1 / 4$ lb. $\$ 1.35 ; \quad$ lb. $\$ 5.00$.

\section{Big Boston Lettuce, Bolgiano's Selected Stock.}

This special and improred stock is superior in quality to any strain of the Big Boston. Many of the large lettuce growers, market gardeners and truckers are nuw placing their orders with us to cover their full requirements for 1922. It can be grown in the open ground for summer or fall, in frame for spring, or forced cool in green house for winter use, producing under each condition large buttery vellow heads filled with sweet. crisp, tender, beautiful, blanched leares. Our stock of this famous lettuce is the finest in the world. Send us your order at once. Pkt. 5 and $10 \mathrm{cts} . ; \quad 0 z .15 \mathrm{cts}$.; $1 / 4 \mathrm{lb} .45 \mathrm{cts}$.; lb. $\$ 1.50$.

\section{A 181. General Pershing Watermelon. Is the leader}

melons; produces wonderful crops of large, in qualits of size melons. The sparkling red flesh is as sweet as honey, just the pleasing flaror; it fairly melts in sour mouth. It is entirely free from hard center and stringiness, set the flesh is frm and compact; rind thin but tough; will stand long distance shipping better than any melon grown. The color of rind is a light pea green; ripens earlier than the Tom Watson for a home melon. You cannot find anything better; for a shipping melon it surpasses all others. We offer you the best quality seed that can be procured. Place jour order early. Pkt. 5 and 10 cts.; 0z. 20 cts.; lb. 75 cts.; lb. $\$ 2.00$.
Bolgiano's "Excell" Watermelons. Without a single "Excell' has positivels proven in the last two or three sears to be the best green rind melon that can be grown. The watermelon growers in the South claim thes can grow more "Excell" for shipping to the acre than any other green melon. It possesses erery quality that is desired by the grower and the consumer. Tigorous grower, rines keep green; deep red flesh, crisp, tender and sweet; splendid shipper. Indeed it is a profitable melon to grow. Our re-selecting has made it a great one. We want to supply you. Order immediately. Pkt. 5 and 10 cts.; 0z. 15 cts.; $1 / 4$ lb. 30 cts.; lb. $\$ 1.00$.

Bolgiano's "Emerald Isle" Pole Lima Bean. Is th e Pole Lima Bean nature has ever supplied. When we first saw it we knew it was a wonder and re-selected our stock until we have today the largest podded, largest seeded, heariest sielder, and most perfect Pole Lima that is grown. The mammoth pods measure 7 to $\$ 1 / 4$ inches long, and $1 \frac{1}{2}$ to 2 inches in width. The vigorous growth of the rines will train rapidly over an arbor, and it is worth seeing the massire pods hanging in great clusters. You will really enjoy growing the "Emerald Isle"; it is earls, fine flaror, and bears abundantly until killing frost. We want to supply sou with our stock. Order at once. Pkt. 10 crs.; pt. 30 cts.; qt. 50 cts.; peck, $\$ 3.50$; bushel, $\$ 12.00$.

\section{Bolgiano's "Enormous" Early Bush Lima Bean.}

This wonderful improved bush lima has attracted the attention of the market gardener and home gardener. It is the earliest large bush lima ever introduced; yields continually from early June until killing frost. The plant grows upright about 30 inches high, producing great clusters of pods measuring 4 to 5 inches long, filled full of large thick beans; delicious flaror, thin skin and tender. This is a very profitable bean to grow. We can supply all early orders. Pkt. 10 cts.; pt. 35 cts.; qt. 60 cts.; peck, $\$ 3.85$; bus. $\$ 14.50$.

Bolgiano's Evergreen Pole Lima Bean. For sereral hare worked faithfully on a green seeded pole lima bean, and we offer you this sear the "Lrergreen" as the most perfect green bean that we have ever seen. The quality is unsurpassed, fine flaror; tender thin skin, and cooks quickly. Bears continually until frost. The rield is enormous, of large pods hanging in clusters, filled full of the most delicious beans. Really sour home garden will not be complete without the "Evergreen," and it will surels be a profitable bean for the market gardener. We have a limited supply. Place your order at once. Pkt. 10 cts.; pt. 35 cts.; qt. 60 cts.; peck, $\$ 3.75$; bushel, $\$ 14.00$.

82. Farr's Benning White Bush Squash. The earliest squash on the market. The color is a beautiful green tinted white, possessed by no other rariety. Always the first to sell for fancy prices on the market. Tender and an excellent cooker. No fiber or hard substance. Enormously productire; fine flaror; growth is bushy with no runners. It is with satisfaction that we can continue to offer sou this unrivalled squash. Pkt. 10 cts.; oz. 15 cts.; $1 / 4$ lb. 45 cts.; lb. $\$ 1.50$. 


\section{Bolgiano's Tested Vegetable Seeds}

Seeds from the Best Market Gardener's Stocks and of Strong Germination

\section{ASPARAGUS}

One ounce to 50 feet of arill; about 4 pounds to the acre.

CUITURE. Sow the seed thinly in rows 1 foot apart in April or May (4 or 5 pounds to the acre) and keep down all weeds. To secure strong, healthy plants, hin the seedings to 3 or 4 inches in the rows, saving only the strongest. The oneyear-old plants should be set out in spring in rich, sandy loam, dug 18 inches deep, into which has been worked-rotted morked If a stiff clay soil is all that manure. If a stifl clay soil sand can be had, add a plenty of sand and sifted coal ashes to loosen it also see that it is well underdrained. In planting for private use, set out in beds 5 feet wide 3 rows in bed, the outer being each 1 foot from the edge, and allow 18 inches between rows, set the plants rows, set the plants from 4 to 6 inches low the surface. If set out in autumn, topdress with 6 inches of manure. For the market, on a large scale, set out 4 by $1 \frac{1}{2}$ feet. Every fall apply a good manure, after the tops have been cut, and in spring fork in Never cut too closely. The roots need the benefit of some flley will weaken and die. Slugs are easily destroyed by applying air-slacked lime or Paris green.
149. Palmetto. It is very early, large yielder, and very regular and even in growth; average bunches contain $\mathbf{1 5}$ shoots. Its quality is unequalled. Pkt. 5 and 10 cts.; oz. 10 cts.; $1 / 4$ lb. 20 cts.; lb. 50 cts.

\section{Argenteuil, or}

Conover's Colossal. Standard variety, large and very prolific. Pkt. 5 and $10 \mathrm{cts}$; oz. 10 cts.; $\quad 1 / 4$ lb. 20 cts.; b. 50 cts.

\section{Columbian Mam-} moth White. Produces large white $\mathrm{sho}$ ot $\mathrm{s}$ without any blanching. Pkt. 5 and $10 \mathrm{cts}$.; oz. 10 cts.; $\quad \mathrm{t} / 4$ lb. 20 cts.; lb. 50 cts.

\section{Asparagus Roots}

Plant either in spring or fall. By mail, 20 cts. per 100 extra.

Colossal. 2-year-old roots ......\$.40 $\$ \mathbf{\$ 1 . 5 0} \quad \$ \mathbf{\$ 1 0 . 0 0}$

Palmetto. 2-year-old roots $\ldots \ldots . .40 \quad 1.50 \quad 10.00$

Columbian Mammoth White. $\ldots . . .40 \quad 1.50 \quad 10.00$

\section{ARTICHOKE}

One ounce will produce about 500 plants.

CUITURE. Sow seeds in January in the greenhouse or in hotbeds in March. Transpalnt when large enough in rows 3 feet beds in March. Transpalnt when large enough in rows 3 feet and protect the plants in winter by taking them in a cellar or $n$ a cold frame, or they may be left outdoors protected by straw n a climate that is not too severe. Artichokes properly cared for last for several years.

26. Green Globe. Pkt. 5 and 10 cts.; oz. 75 ets.

\section{BEANS}

One quart will plant 100 feet of drill; 1 to 2 bushels to acre. CUITURE. About the first of May, if the ground is perfectly warm, select a warm, dry, sheltered spot; dig and manure slightly; make drills 2 inches deep and 18 inches to 2 feet apart; drop the beans 3 inches apart in the drills and cover not more than 2 inches deep. Hoe well in dry wcather to keep down the weeds. Sow every two weeks for a succession. For mailing see Parcel Post Rates, opposite page 2. One quart welghs about 2 pounds.

\section{Green Pod Bush}

King of the Earliest Bean. The earliest and the hardiest of all green podded varieties. It may be planted from a week to ten days earlier than any other green bean, and is not liable to rot during cold wet weather. It produces freely straight long round light green pods. Equally as desirable for planting as a late crop. Pkt. 10 cts.; pt. 25 cts.; qt. 40 cts.; gallon, $\$ 1.35$; peck, $\$ 2.40$; bushel, $\$ 8.50$.

Bolgiano's Stringless Green Pod. A very superior stringless heavy cropper. See description, page 5 in specialties. Pkt. 10c; pt. 25c; qt. $40 \mathrm{c}$; pk. $\$ 2.50$; bus. $\$ 9.00$.

Bolgiano's "Mighty Nice." This wonderful new bean is an improved stock of the Thoroughbred Hopkins Earliest Red Valentine. We have made test side by side, and the "Mighty Nice" is by far the best bean. Pods round and meaty, delicious flavor, very tender, vigorous grower, producing big crops of salable beans. Pkt. 10 cts.; pt. 25 cts.; qt. 40 cts.; 4 qts. $\$ 1.40$; peck, $\$ 2.50$; bushel, $\$ 9.00$.

Bolgiano's May Queen.

When this new beall was first introduced it was evident it would soon become an indispensable variety; long straight finely shaped tender dark green pods makes it a wonderful shipper, which stands long distance; enormous yielder for both spring and fall planting. Pkt. 10 cts.; pt. 25 cts.; qt. 40 cts.; peck, $\$ 2.50$; bushel, $\$ 9.00$.

\section{Bolgiano's Earliest Red}

Valentine. (Improved Round Podded Strain.) Our stock of this very superior bean has been carefully built up to satisfy a most critical market gardener's trade, which trade we cater to. It is ready for picking in $\mathbf{3 5}$ days from plant. ing-earlier than the ordinary Red Valentine Beans. Pkt. $10 \mathrm{c}$; pt. $25 \mathrm{c} ;$ qt. $40 \mathrm{c}$; peck, $\$ 2.40$; bus. $(60 \mathrm{lbs}),. \$ 8.50$.

Burpee's Stringless Green Pod. There is no other variety so absolutely stringless and of uniformly good quality. Very early and prolific, pods are light green in color, round and of medium length. Has a long bearing season, making it very desirable for the small garden. Seed dark brown. Pkt. 10c; pt. $25 \mathrm{c}$; qt. $40 \mathrm{c}$; peck, $\$ 2.50$; bus. $\$ 9.00$.

Black Valentine. An extremely early, vigerous growing green podded variety, earlier than Red Valentine, very long and slender round pods of exceptional quality. As a variety for very early planting it stands cold and damp soil better than any other sort, absolutely rust proof, seed black. Pkt. $10 \mathrm{c} ;$ pt. $25 \mathrm{c} ;$ qt. $40 \mathrm{c}$; peck, $\$ 2.50$; bus. $\$ 9.00$. 


\section{BEANS-Green Podded Bush (Continued)}

Bolgiano's "Emerald Beauty." Is a flat green podded bush bean. Prolific and continuous bearer from early spring until late fall, it is absolutely stringless, Fery tender delicious flavor. The rich green pods rery uniform in shape, make the Emerald Beauty a fine market bean. Pkt. 10 cts.; pt. 25 cts.; qt. 40 cts.; peck, \$2.50; bushel, $\$ 9.00$.

"Giant Stringless" Green Pod. This is a great improvement on old-time popular favorite Valentine Beans. The pods are fully one-third longer, averaging 5 to 6 inches in length; absolutely stringless, very crisp, round, full and fleshy. It is enormously productive. We confidently recommend it either for the home garden or as a profitable variety to grow for market. Pkt. 10 cts.; pt. 25 cts.; qt. 40 cts.; 4 qts. $\$ 1.40$; peck, $\$ 2.40 ;$ bushel, $\$ 8.50$.

Extra Early Refugee. A very early, green-podded variety, with mediumsized, green, fleshy pods; seed drab, freely spotted with dark purple. The vines are smaller and of more upright growth, and leaves a little longer than the Late Refugee. Pkt. 10 cts.; pt. 25 cts.; qt. 40 cts.; peck, $\$ 2.25 ;$ bus. $\$ 8$.

Longfellow. The handsome long round green pods are tender. brittle and stringless when young. Very early maturing variety, recommended for home and market. Pkt. 10 cts.; pt. 25 cts.; qt. 40 cts.; peck, $\$ 2.25$; bus. $\$ 8.00$.

Early Bountiful. Almost a continuous bearer. The plants are of strong growth and produce abundantly stringless flat tender green pods. Very early. Pkt. 10 cts. pt. 25 cts.; qt. 40 cts.; peck, $\$ 2.50$; bushel, $\$ 9.00$.

Refugee, or 1,000 to 1 . A variety rather later than other green-podded varieties. Vines large, spreading, and verg hardy; pods long and green, becoming white, streaked with purple as they mature. Seed sellowish; hearily splashed with bluish black. Pkt. 10 cts.; pt. 25 cts.; qt. 40 cts.; peck, $\$ 2.50$; bushel, $\$ 9.00$.

Dwarf Horticultural. Very productive, pods of medium length with splashes of red. Always stringless and desirable

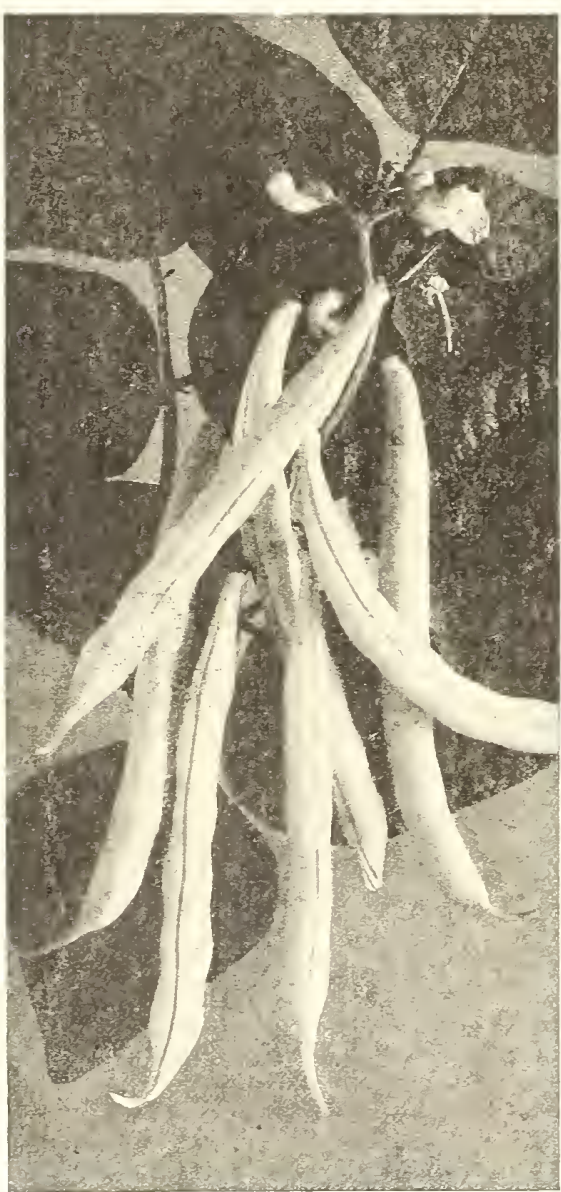

Bolgiano's New Wax. for cooking when young. The green shelled beans are of the finest quality. Pkt. 10 cts.; pt. 25 cts.; qt. 40 cts.; peck, $\$ 2.40$; bushel, $\$ 8.50$.

Boston Pea, or White Navy. The most popular of all the so-called baking beans. Easily grown and very productive. Pkt. 10 cts.; pt. 20 cts.; qt. 35 cts.; peck, $\$ 1.75 ;$ bushel, $\$ 6.00$.

\section{Dwarf Wax Snap}

During the past few years there has been a great improvement in the quality of wax-podded beans. The varieties we offer have all been grown from the finest selected strains and are bound to please the most critical planters. Culture directions same as given for the green-podded Bush Beans.

Bolgiano's New Wax. The pods are round and of a bright golden yellow. Very - productive, bearing pods.in clusters. The medium size, thick fleshed pods are about the size and shape of the Red Valentine. It is free from rust and stringiness. Pkt. $10 \mathrm{c} ;$ pt. $25 \mathrm{c}$; qt. $40 \mathrm{c} ;$ peck, $\$ 2.40$; bushel, $\$ 9.00$.

Improved Rust-Proof Golden Wax. A greatly improved strain; more prolific and superior to the old golden wax. Pkt. 10 cts.; pt. 25 cts.; qt. 40 cts.; peck, $\$ 2.50$; bushel, $\$ 9.00$.

Bolgiano's Best Yet Wax. Among the finest of late introductions. The plant is of an erect and bushy habit, bearing heavily rich lemon yellow, flat pods, brittle and absolutely stringless. Their wonderful yielding qualities recommend them lightly to the home gardener, trucker and canner. You will fall quite in love with their tenderness and delicious flavor, and after growing them once, they will be assured of a permanent place in sour garden. Pkt. 10 cts.; pt. 25 cts.; qt. 45 cts.; peck, $\$ 2.75$; bushel, $\$ 10.00$.

Improved Stringless Refugee Wax. Decided improvement on old Refugee Wax; very desirable for canning. Pkt. 10 cts.; pt. 25 cts. qt. 40 cts.; peck, $\$ 2.50$; bushel, $\$ 9.00$.

Wardwell's Kidney Wax. Very hardy; more robust than any other was bean; very heavy cropper; not liable to rust or blister. The flat pods are 5 inches long and of a rich golden-yellow. Pkt. 10 cts.; pt. 25 cts.; qt. 40 cts.; peck, $\$ 2.50$; bushel, $\$ 9.00$.

Pencil Pod Black Wax. This new bean has been most enthusiastically praised by all who have grown it. Its beautiful yellow pods are straight and from 5 to 7 inches long, well rounded, meaty and deep saddle-backed. They are always solid, brittle and entirely stringless. The plants grow 15 inches high with abundance of large, heary foliage, under which will be found an enormous crop of straight, golden yellow pods. Pkt. 10 cts.; pt. 25 cts.; qt. 40 cts.; peck, $\$ 2.50$; bushel, $\$ 9.00$. 


\section{BEANS}

\section{Dwarf Wax Snap (Continued)}

Bolgiano's New Pearl Wax. Although grown through rainy weather, this bean shows no signs of rust or blight in the worst of weather. It is a sturdy grower with many long pods which though flat are plumper than others of its type, and stringless if picked early. Pkt. 10 cts; pt. 25 cts.; qt. 40 cts.; peck, $\$ 2.50$; bushel, $\$ 9.00$.

Trucker's Reward Wax Bean. This is a synonym for perfection with market gardeners and truckers. The many long flat white pods born ou a plant are all so nearly perfect as to be almost unbelieveable, and they have that exceptional quality of remaining fresh and crisp for a longer time than auy other variety. Pkt. 10 cts.; pt. 25 cts.; qt. 40 cts.; peck, $\$ 2.50$; bushel, $\$ 9.00$.

Hodson Wax. Produces a healthy growth of foliage, resists rust and blight, and is remarkably prolific, with long, straight, thick, handsome, light yellow flai pods. The pods are brittle and tender, of fine texture, and stringless if picked when young. Its remarkable productiveness makes it one of the best late or main crop wax beans for house or market garden. Pkt. 10 cts.; pt. 25 cts.; qt. 40 cts.; peck, $\$ 2.40 ;$ bushel, $\$ 8.50$.

Currie's Rust-Proof Wax. It is hardy and practically rust-proof. Pods grow long, tlat, and are tender and of fine quality. Very early, productive and by far one of the best shipping beans on the market. Pkt. 10 cts.; pt. 25 cts.; qt. 40 cts.; peck, $\$ 2.40 ;$ bushel, $\$ 8.50$.

Davis Kidney Wax. A most popular variety where a hardy wax podded sort is desired. The straight flat pods measure 6 inches long, are of a lich golden yellow, and are tender and of fine flavor if used when the pods are young. Very productive; the white dried beans are desirable for winter use. Pkt. 10 cts.; pt. 25 cts.; qt. 40 cts.; peck, $\$ 2.40$; bushel, $\$ 9.00$.

Sure Crop Stringless Wax. Very prolific and produces pods of the finest quality. The pods are almost round. slightly curved; measure about 7 inches long by $1 / 2$ inch wide, and are always stringless; the meat is very thick. Pkt. 10 cts.; pt. 25 cts.; qt. 40 cts.; peck, $\$ 2.40$; bushel, $\$ 9.00$.

Round Pod Kidney Wax. A strong growing midseason variety, vigorously productive, having round pods about six inclies long, slightly curved, light yellow, wax-like, stringless and of the very best quality. Pkt. 10 cts.; pt. 25 cts.; qt. 40 cts.; peck, $\$ 2.40$; bushel, $\$ 9.00$.

THE COMPLETE VEGETABLE GARDEN COLLECTIONS WILL SAVE YOU MONEY

See page 41.

\section{Climbing, or Pole Beans}

Kentucky Wonder, or Old Homestead. This variety is one of the most desirable and earliest of all the greenpodded running varieties. It is enormously productive, the pods hanging in great clusters from base to top of pole; are of a silvery-green color and entirely stringless; they cook deliciously teuder and melting. Pkt. 10 cts.; pt. 25 cts.; qt. 40 cts.; peck, $\$ 2.50$; bushel, $\$ 9.00$.

Lazy Wife. One of the best for suaps of the later green podded pole beans. The numerous pods, borne in large clusters, are 5 to 7 inches long, broad, thick, fleshy, and entirely stringless. When young they have a lich, buttery flavor, which is retained until they are nearly ripe. The dry beams are excellent for winter use. Seed white. Pkt. 10 cts.; pt. 25 cts.; qt. 45 cts.; peck, $\$ 2.90$; bushel, $\$ 10.50$.

Cherry Pole, or Horticultural. Vines moderately large, light colored leaves; pois short, pale green, but becomingly streaked with bright red; beans large, oval, splashed and spotted with wine-red, and of the highest quality either green or dry. Many people like them better than Limas. Adapted for cool locations and short seasons. Pkt. 10 cts.; pt. 25 cts.; qt. 40 cts.; gallon, $\$ 1.40$; peck, $\$ 2.50$; bushel, \$9.00.

Burger's Stringless Green Pod. White-seeded Kentucky Wonder. The pods average 6 to 8 inches in length, are uniformly straight, of a rich, dark green, and so meaty as to be really saddle-backed. The pods are as entirely stringless as the popular Stringless Green-Pod Bush Bean; they are equally tender and of similar sweet, mild flavor. The dry beans are pure white. Pkt. 10 cts.; pt. 25 cts.; qt.

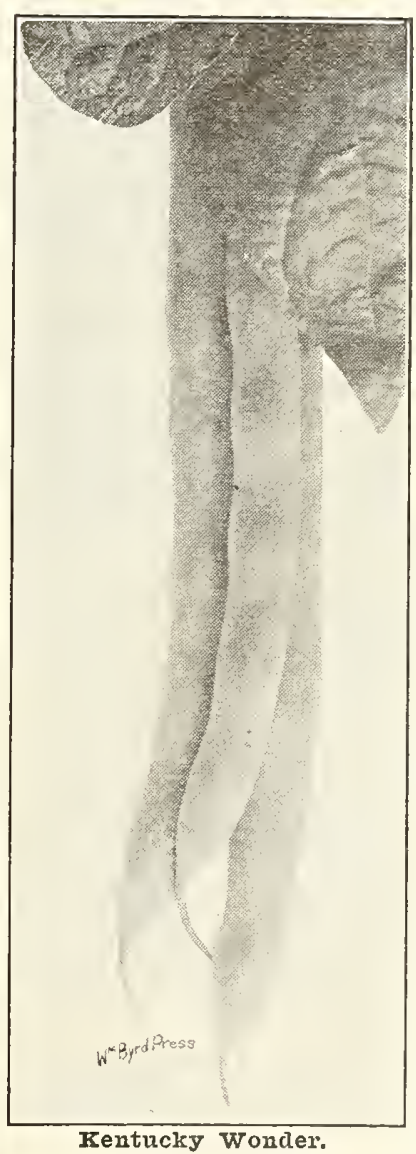
45 cts.; gallon, $\$ 1.60$; peck, $\$ 2.90$; bushel, $\$ 10.50$.

Golden Cluster. $\quad \mathrm{E} \times \mathrm{t}$ r a strong in growth and very productive. The pods are of large size, 7 to 8 inches long by three-quarters of an inch wide. Although fiat, the pods of a rich golden yellow, are stringless and of excellent Havor. The dry seeds are thick and pure white. Pkt. 10 cts.; pt. 35 cts.; qt. 60 cts.; peck, $\$ 3.55$; bushel, $\$ 12.50$.

White Creaseback or Best of All. The best early Stringless Green Podded Pole Bean. Productive. Pkt. 10 cts.; pt. 25 cts.; qt. 45 cts.; peck, $\$ 2.90$; bushel, $\$ 10.50$.

Dutch Caseknife. Early, long, green, flat pods, white seed. Pkt. 10 cts.; pt. 25 cts.; qt. 45 cts.; peck, $\$ 2.90$; bushel, $\$ 10.50$.

Scarlet Runner. In northern locations, where the summers are cool and short, this takes the place of the Large Lima Beans. Plants are of strong, quick growth, bearing large sprays of bright scarlet, pealike flowers. When fully ripened, the dry beans are of bright scarlet, heavily blotched with purple. Pkt. 10 cts.; pt. 30 cts.; qt. 50 cts.; gallon, $\$ 1.85$ 


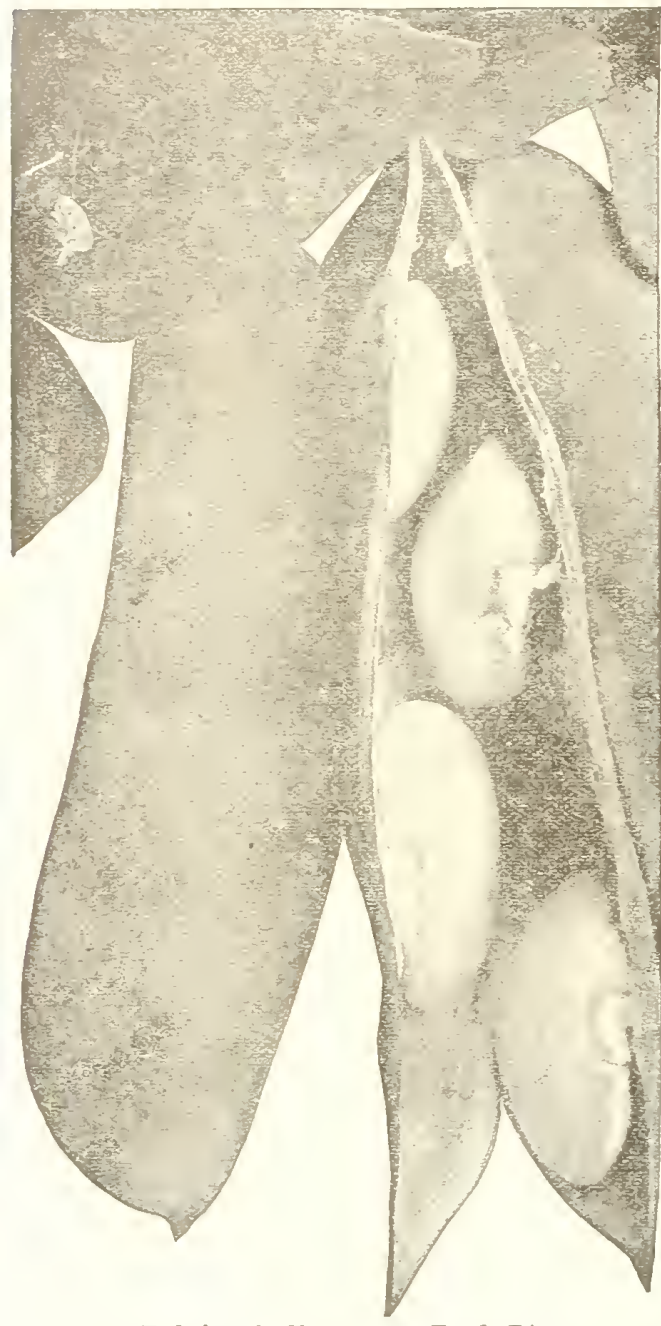

Bolgiano's Fnornous Bush Iima.

\section{BEANS-Bush Lima}

Bolgiano's Enormous Bush Lima. This wonderful Bush Lima is the lorliest, largest and best of all bush chith enormous pods. The delicious green beans are larger than anj other Lima Beans. It yields continuously from June until frost. Both the pods and the Iuscious flarored beans are much larger and considerably thicker than the large bush lima. The seed beans are greenish and rery handsome, while the dried beans of the large bush limas are pure white. Pkt. 10 cts.; pt. 35 cts.; qt. 60 cts.; pk. $\$ 3.85 ;$ bus. $\$ 14.50$.

Fordhook Bush Lima. The Fordhook produces a stiffly erect bush form of growth, and therefore the pods rarely come in contact with the soil, and thus are always clean in appearance. The stalks which produce the blossoms are immense, and pods are almost alwass borne in clusters of from 4 to 6 . The well-filled pods contain from 4 to 6 thick, meaty beans. The shelled beans are of the Potato Lima type and are always of the finest flavor. Our seed has been grown from the finest selected stocks. Pkt. 10 cts.; pt. 35 cts.; qt. 60 cts.; peck, $\$ 3.60$; bushel, $\$ 13.00$.

Improved Large Bush Lima. This bean produces magnificent crops of pods, which measure from 5 to 6 inches long by $11 / 1$ inches wide. As compared with the original Burpee Bush Lima, it is fully a week earlier, and both pods and beans are vers much larger, while the beans, either green or dry, are nearly twice as thick. Pkt. 10 cts.; pt. 40 cts.; qt. 70 cts.; gallon, $\$ 2.00$; peck, $\$ 3.00$; bushel, $\$ 13.00$.

Large Bush Lima. Large pods, well filled with rery large beans, which are identical in size and luscious flavor to the well-known large Pole Limas. Pkt. 10 cts.; pt. 30 cts.; qt. 50 cts.; peck, \$3.50; bushel, $\$ 12.00$.

Henderson's Bush Lima. It has merit in being productive and rery early for family use, and where the trade demands a small-sized bean it has no superior. Makes a delicious dried bean for winter use. Pkt. 10 cts.; pt. 25 cts.; qt. 45 cts.; gallon, $\$ 1.50 ;$ peck, $\$ 2.75$; bushel, $\$ 10.00$.

Wood's Prolific Bush Lima. An "Improred Henderson Bush Lima." Earlier than the Burpee's Bush Lima, but somewhat smaller in size of bean. making a larger growth than others; stems are loaded down with beans in great clusters. Pkt. 10 cts.; pt. 25 cts.; qt. 45 cts.; peck, \$2.90; bushel, $\$ 10.50$.

Dreer's Bush Lima. An excellent rariety that is rery raluable to all on account of its productiveness. The beans grow close together in the pods, are thick, sweet and succulent. Pkt. 10 cts.; pt. 35 cts.; qt. 60 cts.; peck, $\$ 3.85$; bushel, $\$ 14.50$.

\section{Pole Limas one qut. to 150 hilils; 10 to 12 qts. to acre.}

CUITURE. Choose light soil and make small hills 3 feet apart, having previously spaded deeply and fertilized. Plant long pole 2 feet deep in the centel of the hills. Allow 6 beans to each ward. Do not allow more than 3 to climb a pole, but remove extra plants to hills where less than 3 have sprouted. The lima bean is very delicate, and often from slight causes fails to sprout. They should not be planted until the ground is warm.

\section{Bolgiano's New Giant Podded Emerald Isle Pole} Lima. Emerald Isle Pole Limas are the largest podded. largest seeded, heariest cropper of all Limas. They are earlier, more prolific and much larger podded than the King of the Girden. The mammoth pods mensure 7 to $81 / 4$ inches in length and $1 \frac{1}{2}$ to 2 inches in width, and are borne in great clusters. The rines branch or stool out from the main stalk close to the ground, each rine producing 10 to 15 lateral branches. Emerald Isle Pole Lima Beans continue to bear most abundantly until killed by frost. This is the most perfect Pole Lima Bean erer introduced. It grows green, i† dries green, it stays green. Pkt. 10 cts.; pt. 30 cts.; qt. 50 cts.; 4 qts. $\$ 2.00 ;$ peck, $\$ 3.50$; bushel, $\$ 12.00$.

Seibert's Early Lima. In earliness, ease of shelling, size, beanty and quality of the green beans, this rariets leads all other early limas for either the home garden or market. The rines are rigorous and remarkably productire. Pods are medium green, large, flat, about 5 inches long, moderately curred. The green shell beans are rers large, rery tender and of finest quality. Pkt. 10 cts.; pt. 25 cts.; qt. 45 cts.; peck, \$3.00; bushel, $\$ 11.00$.

King of the Garden. Its rine has a luxurious growth, which abounds with large pods, often 6 to $\delta$ inches long, and filled with 5 or 6 perfect beans to a pod. These beans in their green state are large and luscious, but when dry shrink to the ordinary size. It is large, early and prolific and unequalled in quality. Pkt. 10 cts.; pt. 25 cts.; qt. 45 cts.; 4 qts. $\$ 1.75 ;$ peck, $\$ 3.00$; bushel, $\$ 11.00$.

Early Leviathan. One of the newrer rarieties and the best early rariety in cultivation. Vine rery tall and strong; pods long and borne in clusters; beans large and white. It is early, strong-growing and prolific. Pkt. $10 \mathrm{cts.;}$ pt. 25 cts.; qt. 45 cts.; peck, $\$ 2.75$; bushel, $\$ 11.00$.

Carpinteria Pole Lima. A most desirable pole lima for the home and market garden. The rines are strong growing and rigorous, producing an abundance of fine, large, medium green pods, 5 to 6 inches long, usually closely filled with four beans of largest size. much thicker than the average pole lima. The color is distinctive in having a decided greenish tint, an indication of rery finest qualits. Pkt. 10 cts.; pt. 25 cts.; qt. 50 cts.; peck, \$2.75; bushel, \$11.00. 


\section{BEANS-Pole Limas (Continued)}

Bolgiano's Evergreen Pole Lima. The finest variety ever introducer, bearing heavily, large, green tinted, meaty beans. See description, page 6. Pkt. 10 cts.; pt. 35 cts.; qt. 60 cts.; peck, $\$ 3.75$; bushel, $\$ 14.00$.

Improved Challenger. This is one of the leading standard early rarieties that is very popular on account of its productiveness. The quality is exceedingly fine, the beans cooking rich and mealy. Although this is one of the leading varieties for the home or private gardeners, it has become very senerally used by the market gardeners and truckers as well. Pkt. 10 cts.; pt. 30 cts.; qt. 50 cts.; peck, $\$ 3.50 ;$ bushel, $\$ 12.00$.

Jersey Extra Early Lima. Is tell days to two weeks earlier than any other Polc Lima, except the Leviathan. The beans are exceptionally tender and delicious. Pkt. 10 cts.; pt. 25 cts.; qt. 45 cts.; peck, $\$ 3.00$; bushel, $\$ 11.00$.

Carolina or Sieva. Very early and productive. Plump because very popular in the South. Pkt. 10 cts.; pt. 25 cts.; qt. 40 cts.; peck, $\$ 3.00$; bushel, $\$ 11.00$.

\section{MANGEL-WURZEL BEET Cattle Feed Four pounds to Acre.}

97. Improved Sugar Beet. Large growing sort; rich in sugar, hardy and very productive. $1 / 4 \mathrm{lb} .20 \mathrm{cts}$; $\mathrm{lb} .40 \mathrm{cts}$.

53. Golden Tankard Yellow-Flesh Mangel. D e e p yellow-fleshed, of milk-producing quality. $\quad 1 / 4$ lb. 20 cts.; lb. 40 cts.

49. Giant Mangel-Wurzel. The heaviest cropper, of mammoth size; fine quality. r/4 lb. 20 cts.; lb. 50 cts.

New Jumbo Mangel. For milch cows and cattle generally the New Jumbo Mangel has no equal. It is a milkproducer of the highest quality, $1 / 4$ lb. 20 cts.; lb. 50 cts.

Golden Giant Intermediate. Root intermediate between the long and the globe-shaped. Flesh white, firm and sweet, much liked by cattle. $1 / 4$ lb. $20 \mathrm{cts}$.; lb. $40 \mathrm{cts}$.

Klein-Wanzle Bener Elite. This variety at the present time has probable a wider cultivation than any other Sugar Beet. While not as a rule equal to the Vilmorin in saccharine richness, it is considerably more productive. $1 / 4 \mathrm{lb} .20$ cts.; lb. 50 cts.

\section{Bird Seed}

C58. Canary Seed. L.b. 15 cts. Postpaid.

C62. Bird Rape. Lb. 20 cts. Postpaid.

C60. Hemp. Lb. 15 cts. Postpaid.

Sunflower Seed. Lb. 15 cts. Postpaid.

\section{BRUSSELS SPROUTS}

Brussels Sprouts look very much like little heads of Cabbage, and growing closely on the stalk (see illustration) a single plant produces a great many from the ground level to the tip. The plants are very hardy and may remain outdoors during the winter in many locations. The quality and flavor of the sprouts are much improved by frost. Seed should be sown the same as it is customary to sow for late cabbage.

167. Perfection. Grows about $21 \%$ feet high. Very productive. Pkt. 5 and 10 cts.; oz. 25 cts.; 1/4 lb. 75 cts.; lb. 2.50 .

7. Paris Market. This is much dwarfer than the preceding and bears a large crop of handsome sprouts. Pkt. 5 and 10 cts.; oz. 20 cts.; $1 / 4$ lb. 60 cts.; lb. \$2.00.

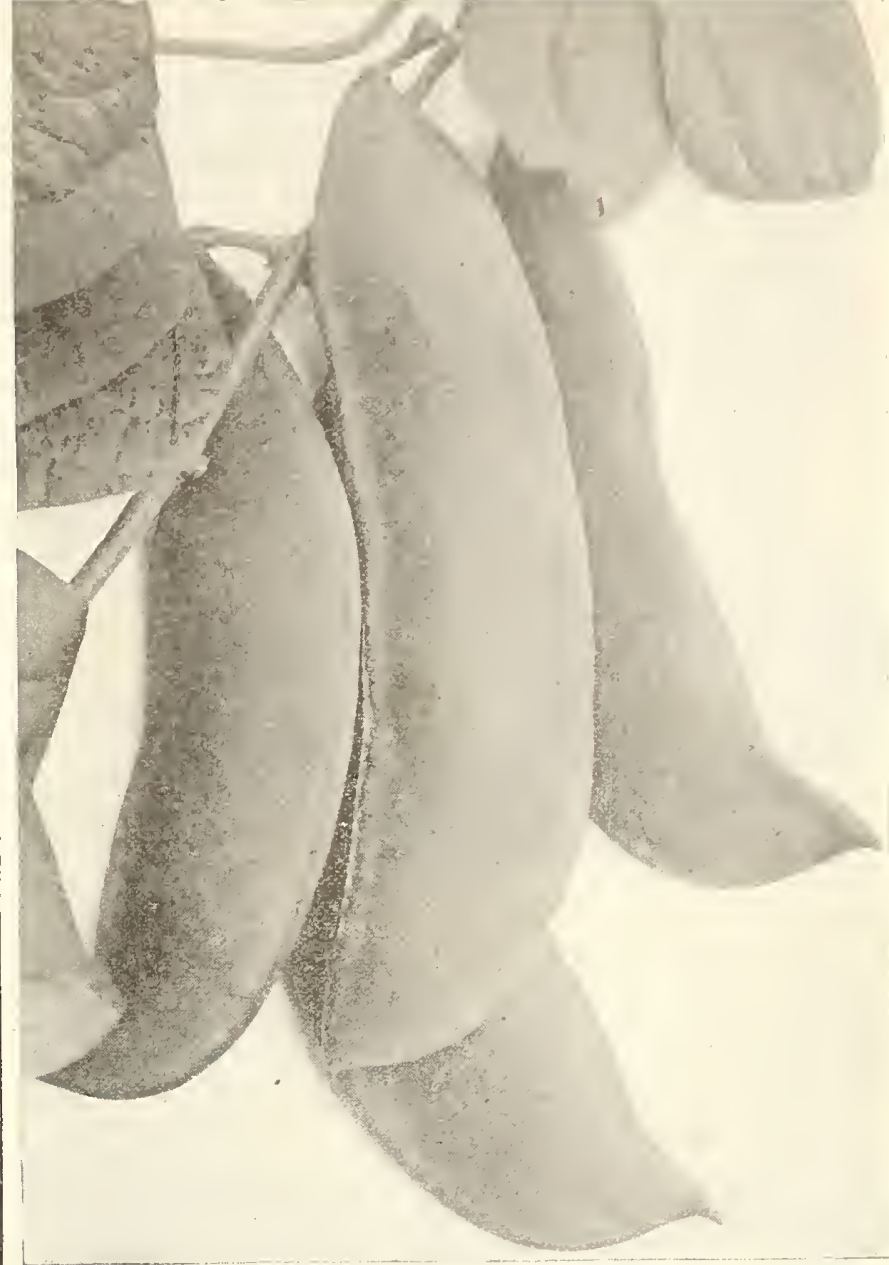

Bolgiano's Evergreen Pole Lima Bean.

\section{SWISS CHARD, or SPINACH BEET}

The rapidly. increasing popularity of this vegetable is well deserved, for not only do the leaves make splendid greens when cooked like Spinach, but the leaf stalks are particularly palatable if prepared in the

same manner as Asparagus, The culture is the same as for Beets, and it can be grown thruout the entire summer.

145 . Large

Ribbed White Produces broad wh it e le a f stalks. Pkt. 5 and 10 cts. oz. 15 cts. r/4 lb. 25 cts.; lb. 75 cts.

\section{Lucullus.}

Plants growing 2 to $2 \frac{1}{2}$ feet tall with many creamy $w$ h i t e curled 1 e a $v$ e s c a rried on broad, $\quad \mathrm{th} \mathrm{i} \mathrm{c} \mathrm{k}$ stalks. Pkt. 5 and $10 \mathrm{cts}$; $0 \mathrm{z}$. 15 cts.; $\quad 1 / 4$ lb. 25 cts. Ib. 75 cts.

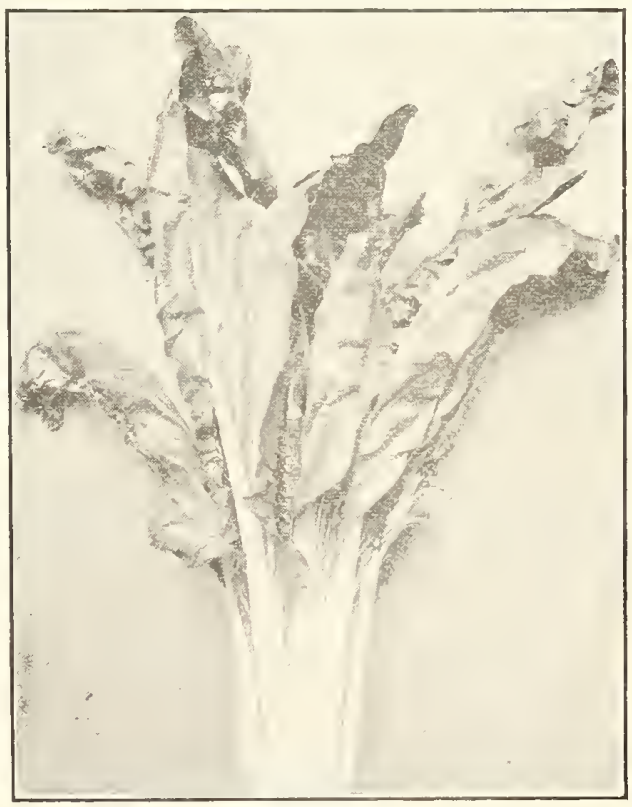

Swiss Chard. 


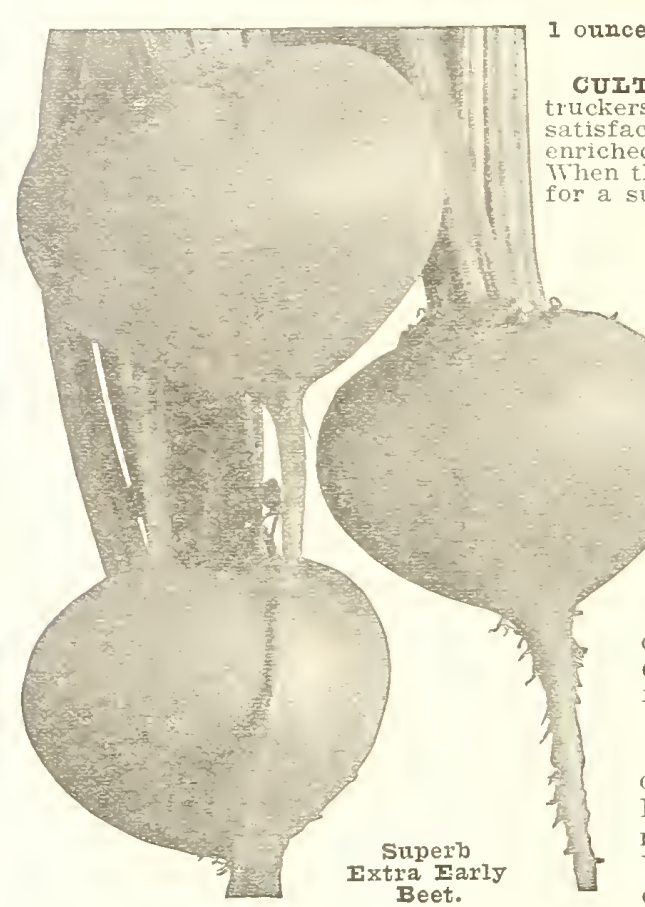

CUITURE. Our best seed is grown from selected transplanted roots and have given truckers and market gardeners, who appreciate a high standard of perfection, the utmost satisfaction. The soil best suited for beet culture is that which is rather light and well nriched. Sow in drills 1 foot a part and 1 inch deep. as early as the ground can be worked. Then the plants are large enough, thin out to stand 6 inches apart in rows; continue sowing

C57. Superb. (See illustration.) Has taken the lead among early turnip-shaped Beets entirely by superior merits of ererything pertaining to a Beet to make a recognized leader. It is very earls, indeed; it is $S$ to 10 dass ahead of any other early sort now offered. The shape is uniformly perfect, being entirely free from fibrous side roots, which are so objectionable; in fact. it is the smoothest Beet within our knowledge. The flesh is a rich, dark blood-red, tender, crisp, and deliciously sweet, besides haring a rery small top: is an ideal rariety for bunching. Will produce a good crop inside of seven weeks from soming. Is excellent as a forcing sort or as a main crop. Pkt. 5 and 10 cts.; 0z. $15 \mathrm{cts}$; I/4 lb. $30 \mathrm{cts.} ;$ Ib. $\$ 1.00$.

45. Wonderful Early Spring. (See page 5.) Extra quick in maturing, or, fin root, small tops, deep dark red Grown in hot beds. cold frames or open ground. Pkt. 5 and 10 cts.; oz. 15 cts.; r/4 lb. 45 ct.s.; lb. $\$ 1.50$.

Bolgiano's Deep Blood Beauty. Otir long experience in the growing of Beets has shown this new strain of Beet to be the Best Extra Earls Deep Blood Turnip Beet. Roots are globular and peculiarly smooth: color is of blood red. rers crisp, tender, fine-grained and sweet, remaining so for a long time. Te believe this excellent new stock will produce a crop more uniform in shape, color and quality than any Beet. Pkt. 5 and 10 cts.; oz. 15 cts.; 1/4 1b. 25 cts.; 1 lb. 75 cts.

108. Bolgiano's Extra Early Eclipse. It is valuable for home gardens and indispensable for market gardens. It is remarkable for rery rapid growth, the perfect flesh, and for its dwarf foliage. Roots bright, glosss red, rery fine grained. Pkt. 5 and $10 \mathrm{cts}$; 0 oz. $15 \mathrm{cts} . ; 1 / 4 \mathrm{lb} .20 \mathrm{cts}$.; lb. $50 \mathrm{cts}$.

142. Crimson Globe. This splendid net rariety is a most raluable introduction. The color is most distinct, being of a rich, deep crimson; in shape tiniformls a perfect globe: the slin is smooth and clean. It is early in maturing. and is proring specially desirable and profitable for market gardeners and truckers. Its attractire appearance, splendid flaror and other fine table qualities make it a farorite. Pkt. 5 and $10 \mathrm{cts}$; 0 z. $15 \mathrm{cts} . ; \mathrm{r} / 4$ lb. $20 \mathrm{cts}$.; lb. $60 \mathrm{cts}$.

125. Crosby Extra Early. A гегy superior strain of blood-red Egyptian, carefulls selected for years br Mr. Crosbr, a noted market gardener, whose aim was to secure a perfect forcing variets. The results obtained were handsome form, good size, few snall tops, rers small tap root, fine qualits, and, above all, quick, rapid gromth. The shape is rery desirable, not flat like the ordinars Egrptian, nor so round as Eclipse. Pkt. 5 and 10 cts.; 0z. 15 cts.; 1/4 lb. 20 cts.; lb. $60 \mathrm{cts}$.

Extra Early Dark Red Egyptian. The best variety for forcing. Excellent for first earls out-of-door crop, being the rers first to produce. The roots are vers dark and moderately thick and little romnded on top growing to a good arerage size. The flesh is dark purplish red, firm, crisp and tender. Pkt. 5 and $10 \mathrm{cts}$; 0z. $15 \mathrm{cts}$.; 1/4 lb. $20 \mathrm{cts}$.; lb. $50 \mathrm{cts}$.

Lentz Extra Early. Color a deep blood red, tender and sweet at all stages of its growth. Has small top and can be used six weeks from sowing. Ters productire. a splendid keeper and shipper. Pkt. 5 and 10 cts.; 0 z. 15 cts.; 1/4 lb. 30 cts.; lb. $\$ 1.00$.

133. Dewing's Blood Turnip. Tops medium size and veins dark red; leares creen; roots dark red, turnip-shaped, with large top; flesh carmine red, zoned with lighter shade; tender, sweet and a rers good keeper. Pkt. 5 and 10 cts.; $15 \mathrm{cts}$; $1 / 4$ lb. 20 cts.; 1b. $60 \mathrm{cts}$.
122. Edmands Blood Turnip. The flesh is deep bloodred in color and exceedingly street and tender in qualits. It is round and smooth in shape and of good marliet size. It has a small top. Pkt. 5 and 10 cts.; $0 z .15$ cts.; $1 / 4$ lb. 20 cts.; lb. 60 cts.

153. Half Long Blood. We recommend this beet to be of great ralue. Its roots are of an attractive shape, its flesh is dark red and rery tender and sweet. As a fall and winter beet it has few eruals. Pkt. 5 and 10 cts. 0 z. 15 cts.; 1/4 lb. 25 cts.; lb. 65 cts.

93. Extra Early Bassano. This Beet is sometimes called Philadelphia Sugar Beet. Root large, turnip shaped; come very early. and are rery sweet and tender: flesh bright light red. Pkt. 5 and $10 \mathrm{cts}$; 0z. $15 \mathrm{cts}$; 1/4 lb. $20 \mathrm{cts}$; $1 \mathrm{~b} .60 \mathrm{cts}$.

103. Detroit Dark Red Turnip. One of the best deep red Turnip Beets for market gardeners or home use. Its small u p r i g h tg row ing tops, ea r l. maturing, and fine globular shape and color of the roots make it rer's popular with етеrs one who plants it. Pkt. 5 and 10 cts.; $0 z$. 15 cts.; $1 / 4$ lb. 20 cts.; lb. 60 cts.

\section{Bastian's} Early Blood Turnip. A bright red medium early beet of rers good quality for home or garden use. Pkt. 5 and 10 cts.; 0z. 15 cts.; r/4 lb. 20 cts.; lb. 65 cts.

\section{Long}

Smooth Blood. Pkt. 5 and 10 cts.; oz. $15 \mathrm{cts}$; $1 / 4 \mathrm{lb}$. $20 \mathrm{cts}$.; lb. $60 \mathrm{cts}$. 


\section{CABBAGE}

One ounce of seed produces about 2,500 plants. Four ounces will grow enough plants to set an acre.

CUITURE, For very early use sow in January or February in hotbeds: put out when the plants are strong enough into other hotbeds, or sow in cold frames in March; transplant, when danger from killing frost is past, to open ground in rows 2 feet apart and 18 inches in the row. For a succession sow in the open ground the last of March or early in April. The autumn and winter varicties sow in April or early in May, in shallow drills, 3 or 4 inehes apart; transplant early in July in rows $2 \frac{1}{2}$ feet apart and 2 feet in the row. Cabbage sueeeeds best in fresh, rieh soil, well manured and deeply dug or plowed.

\section{Extra Early Varieties}

80. Select Jersey Wakefield. Heads pointed at top, and plants produce but few outside leaves. Our seed has been most carefully selecterl. Pkt. 5 and 10 cts.; oz. 25 cts.; 1/4 lb. 75 cts.; lb. $\$ 2.50$.

Big Winner Wakefield. No other cabbage of which we have knowledge has aroused such enthusiasm among cabbage growers as has our "Big Winner." It has the same general characteristics of other Wakefield Cabbages, the head being conical with a rounded or blunt point. It is, however, far superior to other strains of Wakefield Cabbage, being nearly double the size and better quality, and at the same time is fully as early. It has few outer leaves, permitting close plantings. Pkt. 5 and 10 cts.; 0z. 25 cts.; I $/ 4$ lb. 80 cts.; lb. $\$ 2.75$.

105. Large Charleston Wakefield. True Long Island grown. About 5 to $\mathbf{1 0}$ days later than Early Jersey Wakefield; the heads are fully one-half larger and can easily be planted 20 inches in the rows. Pkt. 5 and 10 cts.; oz. 25 cts.; $1 / 4$ lb. 75 cts.; lb. $\$ 2.50$.

A80. Bolgiano's Early Large York. This is a very valuable early variety, and follows the Express in heading. The heads are round, heart-shaped, and very firm. Pkt. 5 and 10 cts.; 0 . 25 cts.; $1 / 4$ lb. 75 cts.; lb. $\$ 2.50$.

Extra Early Express. This, the earliest of all cabbages, has produced marketable heads in 80 days from the sowing of the seed. It can be planted close and yields large, early, paying crops. Pkt. 5 and $10 \mathrm{cts}$.; $0 z .25 \mathrm{cts}$.; $\mathrm{I} / 4 \mathrm{lb}$. $80 \mathrm{cts}$; lb. $\$ 2.75$.

New Leader. As early as Wakefield, yields 12,000 heads, one-third more per acre than any other extra early cabbage. The lieads are compact and solid from the time a head is formed and keeps so until thoroughly matured, thus enabling extremely early cutting of small, hard heads, or later when the Wakefield comes in, of large, thoroumhly matured, solid, round, flat beads. Pkt. 5 and 10 cts.; oz. 25 cts.; I/4 lb. 80 cts.; lb. $\$ 2.75$.

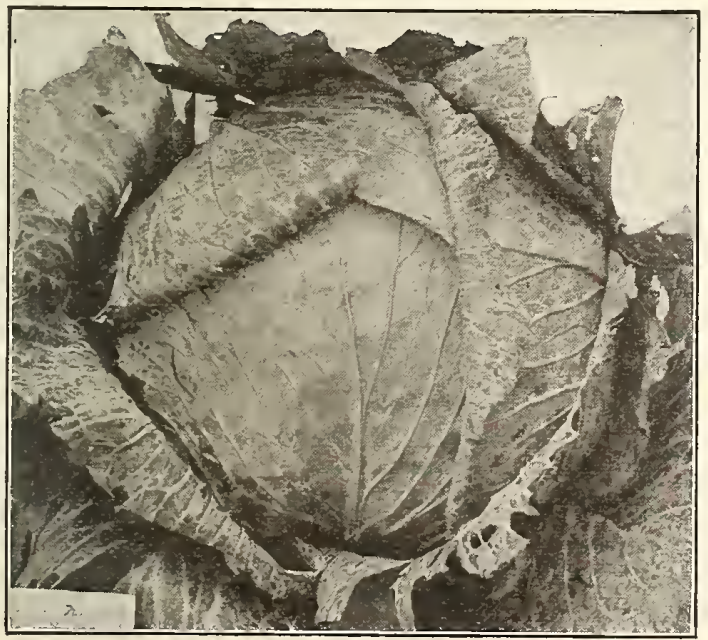

New Early Cabbage.

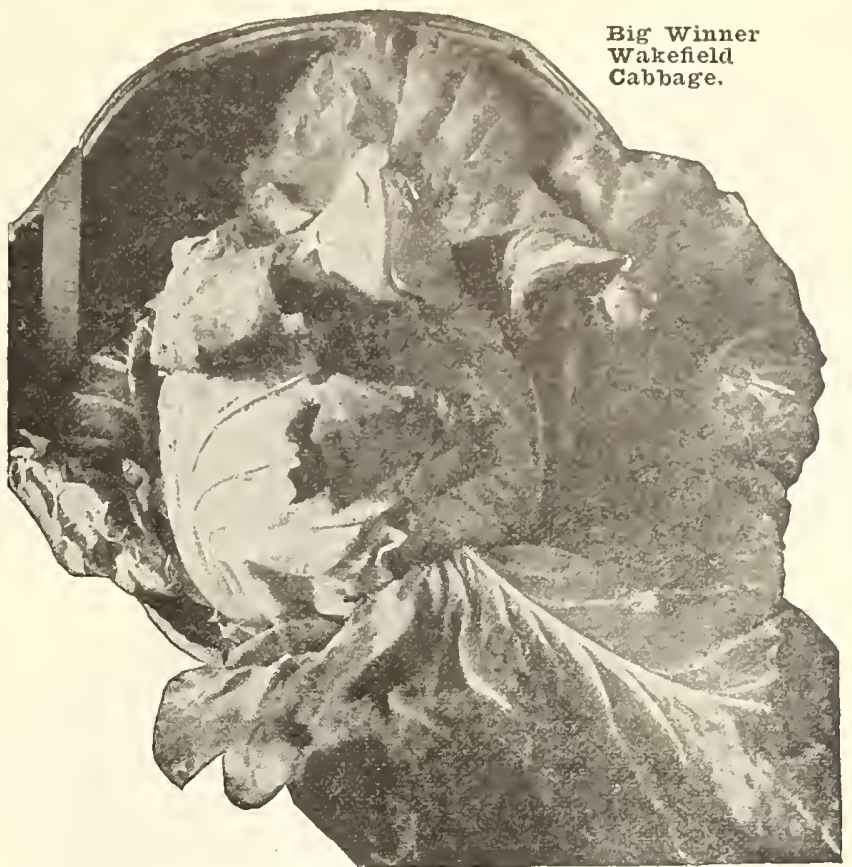

213. Early Winnigstaat. A standard second-early rariety; very hard heads. Pkt. 5 and 10 cts.; 0z. 25 cts.; I/4 lb. 75 cts.; lb. $\$ 2.50$.

\section{Early Varieties}

Bolgiano's Early "Square Deal." For a fine, solid t e $n d$ e r, uniform early, flat cabbage, Bolgiano"s "New Square Deal" Cabbage challenges all other types. The demand for a cabbage of this character led us, by the most rigid and careful selection during the past five years, to mature this cabbage, which we are confident will give all our friends and customers a "Square Deal" every time. Pkt. 5 and $10 \mathrm{cts}$; 0z. $25 \mathrm{cts}$.; I/4 lb. 85 cts.; lb. $\$ 3.00$.

210. Copenhagen Market. Undoubtedly the finest large, round-headed early Cabbage. The heads average about 10 pounds each in weight, are rery solid and of fine quality. It matures as early as Charleston Wakefield, and will give a hearier yield per acre than that well-known variety. The plant is short-stemmed, the leares always tightly folded. Pkt. 5 and $10 \mathrm{cts}$.; 0z. $25 \mathrm{cts}$; $1 / 4 \mathrm{lb} .85$ cts.; Ib. $\$ 3.00$.

223. Allhead Early. 'Ihis famous Cabbage is consider ably larger than Early Summer Cabbage that is equally as early. The deep flat heads are remarkably solid and the most uniform in color, form and size. The hard heads grow so free from spreading leares that fully one thousand more heads than usual with large Cabbage can be obtained to the acre. It is really an all-the-yenr-round Cabbage, being equally good for winter if seed is sown about August. Pkt. 5 and 10 cts.; 0z. 25 cts.; I/4 Ib. 75 cts.; lb. $\$ 2.50$.

160. Bolgiano's Early Flat Dutch. The heads are large and solid. Pkt. 5 and $10 \mathrm{cts}$.; $0 \mathrm{z} .25 \mathrm{cts} . ; \mathrm{I} / 4 \mathrm{lb}$. 75 cts.; lb. $\$ 2.50$.

C2 1. Enkhuizen's Glory. This Cabbage from Holland is a good early sort making fine, large, tender and fine grained heads, Pkt. 5 and $10 \mathrm{cts}$; 0z. $25 \mathrm{cts}$; I/4 Ib. 85 cts.; lb. $\$ 3.00$.

117. Bolgiano's New Early. This is the finest, large very early cabbage. Forms solid, compact heads, and the leaves grow close to the head, thus allowing many more cabbage to be grown on the acre than other sort. Its earliness is one of its remarkable features. Pkt. 5 and 10 cts.; oz. 25 cts.; $1 / 4$ lb. 75 cts.; lb. $\$ 2.50$. 


\section{CABBAGE-Early Varieties (Continued)}

I 15. Succession. True American grown. Matures ten days later than Early summer and larger in growth. Pkt. 5 and 10 cts.; oz. 25 cts.; $1 / 4$ lb. 75 cts.; $1 \mathrm{~b} . \$ 2.50$.

101. Improved Early Summer. A superior secondtarls sort; produces large and solid heads of finest quality; popular in the South. Selected stock. Pkt, 10 cts.; oz. 25 cts.; $1 / 4$ lb. 75 cts.; lb. $\$ 2.50$.

43. All Season. Will do to plant at an season of the year, with assurance that the crop will be fine, large heads. and in erery respect gire satisfaction. It grows large. Pkt. 5 and $10 \mathrm{cts}$.; $0 \mathrm{z} .25 \mathrm{cts}$. $1 / 4$ lb. $75 \mathrm{cts}$. $1 \mathrm{~b} . \$ 2.50$.

\section{Late, Fall and Winter Varieties}

The possibility of having green iood during the snowy months s realized by growing fall cabbage and storing it for winter use the varieties which we list below produce hard heads that will seep well when properly stored.

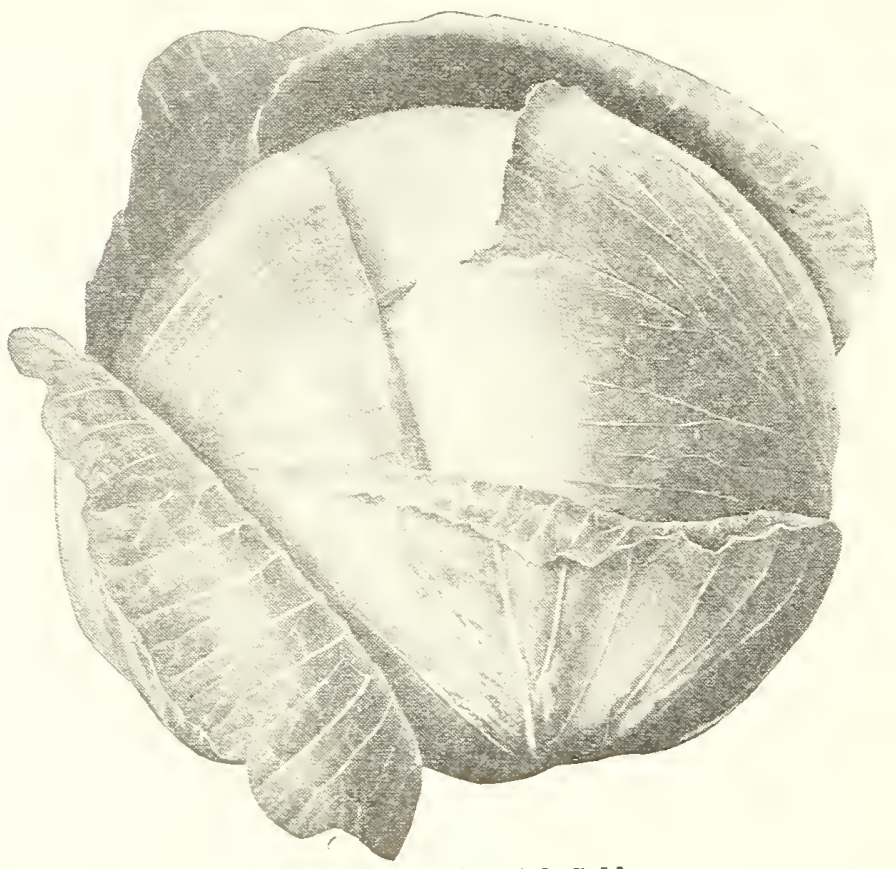

Extra Iarge Flat Dutch Cabbage.

89. Extra Large Flat Dutch. Fills a long-felt want of our Cabbage growers. They anxiously look for a variety which includes large size, solidity, uniformity, good keeping qualities and quick derelopment. so that by planting later than was necessary with the old Flat Dutch ther could aroid the cabbage morm and yet mature their crop. Matures in three weeks less time than the Late Flat Dutch. Pkt. 5 and $10 \mathrm{cts.} ;$ oz. 25 cts.; $1 / 4$ lb. 75 cts.; lb. $\$ 2.50$.

\section{Bolgiano's Superior Stock}

Large Late Drum-Head. This splendid Cabbage produces tnormous heads and is an all-head Cabbage. Its good keeping quality makes it a first-class sort to carry orer winter or for long distance shipping. Pkt. 5 and 10 cts. oz. 25 its.; $1 / 4$ lb. 75 cts.; lb. $\$ 2.50$.

192. Autumn King. The plant is of extra-strong growth *ith dark green leares growing closely about the large flatcened heads. In sood soil it will produce heads of enormous size. but, of course. requires a longer season for growth than do the smaller varieties. Seed somn the first of June will oroduce fine heads in time to put away for the winter. Pkt. 5 and 10 cts.; oz. 25 cts.; 1/4 lb. 75 cts.; lb. $\$ 2.50$.

The Lupton. Pkt. 5 and $10 \mathrm{cts}$; 0z. $25 \mathrm{cts}$; 1/4 lb. 75 cts.; lb. $\$ 2.50$.

Bolgiano's Ringleader. Pkt. 5 and 10 cts.; oz. 25 cts.; lb. 85 cts.; lb. $\$ 3.00$.
206. Danish Roundhead. A late rariety, but matures earlier than the Danish Ball Head. The heads are round and have a short stalk, and for solidits is ahead of all others. The interior leares are pure white and of sweet flavor. It is a healthy variety and able to stand hot weather and resist disease. Danish grown. Pkt. 5 and $10 \mathrm{cts}$; 0z. $25 \mathrm{cts}$; I/4 lb. 85 cts.; lb. $\$ 3.00$.

\section{Improved Perfection Drumhead Savoy} (True American). There are many rarieties of Saroy Cabbage. but there is one variety. "Bolgiano's Perfection," that surpasses them all for uniformity of heads, beauty of curl, extra large size and superior heeping qualities. Pkt. 5 and 10 cts.; 0z. 25 cts.; 1/4 lb. 75 cts.; lb. $\$ 2.50$.

129. Premium Flat Dutch. This is an old farorite and standard with many truckers and much improred by careful selection. Pkt. 5 and 10 cts.; oz. 25 cts.; 1/4 lb. 75 cts.; Ib. $\$ 2.50$.

C25. Volga. This variety is of recent introduction and has much merit, and makes large, round heads which are rery solid. It is hardy and will do well in erery section where Cabbage is grown. Pkt. 5 and 10 cts.; oz. 25 cts.; $1 / 4$ lb. 75 cts.; lb. $\$ 2.50$.

32. Mammoth Red Dutch. The largest red Cabbage and heads vers solid, and is deep red color to the very center. No Cabbage is better for boiling or for slaw, and is beautiful red color specially fits it for pickling. Pkt. $\overline{5}$ and $\mathbf{1 0}$ cts.; oz. 30 cts.; 1/4 lb. $\$ 1.00 ;$ lb. $\$ 3.50$.

\section{Pe-Tsai, Chinese or Celery Cabbage}

This Chinese vege-

table has become

many large cities.

The Chinese Cab-

bage is very easily

brown, and in fairly

rich soil quickly

produces handsome h eads resembling apt to bolt to seed during hot weather, therefore best results are obtained by sowing seed the latter part of the summer (August 1st to 15 th) and having plants stand about 15 inches apart in the l'ows. Heads are easily blanched and may be used as a salad or boiled like cabbage. Plants are rather tender and will not stand frost.

C55. Pe-Tsai, Chinese or Celery Cabbage. Pkt. 5 and $10 \mathrm{cts.;}$ oz. $25 \mathrm{cts}$.; $1 / 4 \mathrm{lb} .85$ cts.; lb. \$3.00.

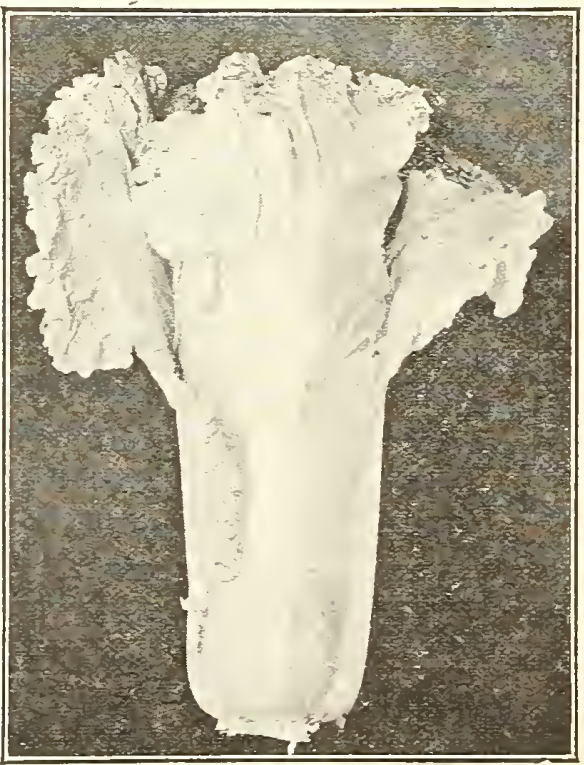

Pe-Tsai, or Chinese Cabbage. 


\section{CAULIFLOWER}

Cauliflower, although one of the most delicions vegetables, is but little grown except by professioual gardeners because of the erroneous notion that it is so diflicult to grow that only the slibled gardeuers can produce it. Any one will be reason ably sure of success with this most desirable vegetable if the culture directions given below are carefully followed.

CUITURE. Sow the seed in a hotbed in January r. Feruary, and when the plants are large enough transplant threc inches apart in boxes or in other hotbeds until time to plant out. If hardened off they hotbeds until time to plant out. If hardenca off they ground ean be properly prepared, $21 / 2$ feet apart each way. Keep them well hoed and bring the earth gradually up to their stems, watering freely in dry weather and especially when they begin to head. Cauliflower suceeeds best when planted in frames at the crinter and brought to maturity before the close of winter and brough to maturity before in the autumn and are sown and managed similar in the autumn and

3. The Twentieth Century. Where other Cauliflower fails, gardeners should try this strain. The heads are all large, aud every plant will make a head when the conditions are right. In Long Island, $N$. Y., this strain has given the best satisfaction. The heads are large, compact and white. weighing more than any other sort. The outside leaves are smaller than any other variety; for this reason it can be planted closer, thereby getting a greater number of heads to the acre. It is the earliest and makes big money for the grower. Pkt. 10 and 15 cts.; $1 / 2$ oz. $\$ 1.40 ; \quad$ oz. $\$ 2.25$; I/4 lb. $\$ 8.00$.

33. The Success. Having received many inquiries for a satisfactory variety to produce heads late in the season, we were much pleased when our attention was called to The Success. With the introduction of The Success we feel many gardeners may now prolong their growing season. It forms firm large curds or heads, pure and white in color. and always solid and firm. Pkt. 10 and $15 \mathrm{cts}$.; $1 / 2 \mathrm{oz}$. $\$ 1.25 ; \quad$ oz. $\$ 2.00 ; \quad 1 / 4$ lb. $\$ 7.50$.

24. Early Snowball. Our seed this season is as usual from selected stock, and we go to the grower knowing that we give them seed that has been grown for us by the best grower in Europe. It grows dwarf, with large, white heads. and very early. Our sales have increased each year in the sale of Cauliflower, and we have spared no expense in perfecting this fine strain. We feel sure that if you once try this seed you will have no other, because it is the best. As a profitable crop there are few that equal it, and anyone who gets our seed should make a success and money. Good Cauliflowers always sell. Pkt. 10 and 15 cts.; $1 / 2$ oz. $\$ 1.25$; oz. $\$ 2.00 ; \quad 1 / 4$ lb. $\$ 7.50$.

\section{Danish Giant, or New Dry Weather Cauliflower.} Will produce splendid crops in very dry locations. Pkt. 10 and 15 cts.; $1 / 2$ oz. 50 cts.; oz. 75 cts.; 1/4 lb. $\$ 2.70$; lb. $\$ 10.00$.

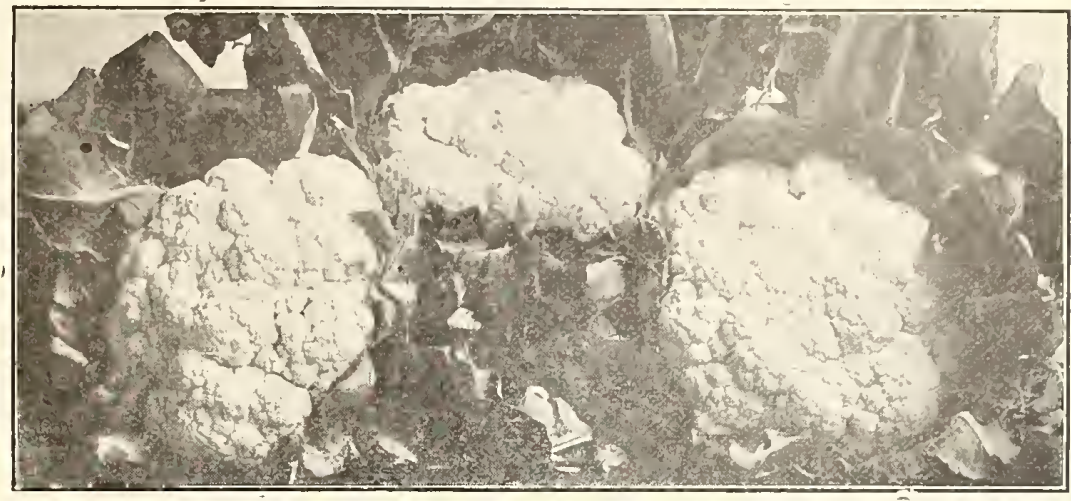

The Twentieth Century Cauliflower.

Extra Early Dwarf Erfurt. A remarkably sure heading early Cauliflower. It is of dwarf habit with short outsidt leaves similar in most respects to Farly Snowball, and near. ly as early. The heads when ready for market are medium to large size. The curcl is white, exceptionally deep and of finest quality. It will give excellent results either in tht home garden or for market use. Pkt. 10 and $15 \mathrm{cts}$.; 1/2 oz. $\$ 1.40 ; \quad$ oz. $\$ 2.25 ; \quad 1 / 4 \mathrm{lb}$. $\$ 8.00$.

166. Veitch's Autumn Giant. This is known on the Pacific Coast under the name of California Wonder. It is very late in maturing and heads or curds are not so wel formed nor so tight as those of the earlier varieties. Pkt. 10 and 15 cts.; $1 / 2$ oz. 50 cts.; 0z. 75 cts.; $1 / 4$ lb. $\$ 2.70$ : lb. $\$ 10.00$.

\section{CHICORY}

22. Witloof (French Endive). Witloof Chicory is used principally as a winter salad. The seed should be sown ir the open ground not later than June. The plants form large parsnip shaped roots which are lifted in the fall, trimmed of leaves and stored in soil in a cool place until wanted for forcing. The roots can be forced in any warm cellar or room, requiring about one month to make edible sprouts. Pkt. 10 cts.; 0z. 20 cts.; I/4 lb. 60 cts.; lb. $\$ 2.00$.

\section{CORN SALAD}

One ounce will sow about 18 square feet and six pounds will sow an acre.

112. Broad Leaved (Large Seeded). Delicious salao used during the winter and spring months as a substitute for lettuce, and is also cooked and used like Spinach. Sow in spring in drills 1 foot apart. It will mature in six weeks For early spring use sow in September and winter over likt Spinach. Pkt. 5 and $10 \mathrm{cts}$.; 0z. $15 \mathrm{cts}$.; $1 / 4 \mathrm{lb} .30 \mathrm{cts}$. lb. $\$ 1.00$.

\section{FROST PROOF CABBAGE PLANTS}

\section{READY FOR IMMEDIATE DELIVERY}

Mature Heads Two to Three Weeks Earlier Than Your Home Grown Plants-Will Double Your Profits. EARLY JERSEY WAKEFIELD, CHARLESTON LARGE TYPE WAKEFIELD, SUCCESSION, EARLY FLAT DUTCH

Prices by parcel post, postage prepaid: 100 to 400 plants at 50 cts. per $100 ; 500$ for $\$ 1.75 ; 1,000$ or more for $\$ 3.25$ per 1,000 plants.

Prices by express, buyer paying charges: 1,000 to 4,000 at $\$ 2.25$ per 1,000 plants; 5,000 to 8,000 at $\$ 2$ per 1,000 . Plants are packed for parcel post shipment-100, 200, 300, 400,500 or 1,000 plants to the package; for express shipment-1,000 or 2,000 plants to the package. Order only in these quantities. We pack only one variety to the package.
They weigh about 20 pounds per thousand plants, packec for shipment.

TERMS: Cash with order. No plants slipped C. O. D We advise that you have all shipments of one thousano plants or less sent by parcel post. They make quicker timt and are delivered direct to you by the mail carrier. On larger lots inquire of your express agent what the charges will be. To a great many points the parcel post rates are as low as express rates. When rates are near the same always order by parcel post, as time and service are better. 


\section{TABLE CARROTS}

Arrange for an ample supply of Carrots, as they are highly mutritious, and if sowings are frequently made it is possible to maintain a supply of roots the year round.

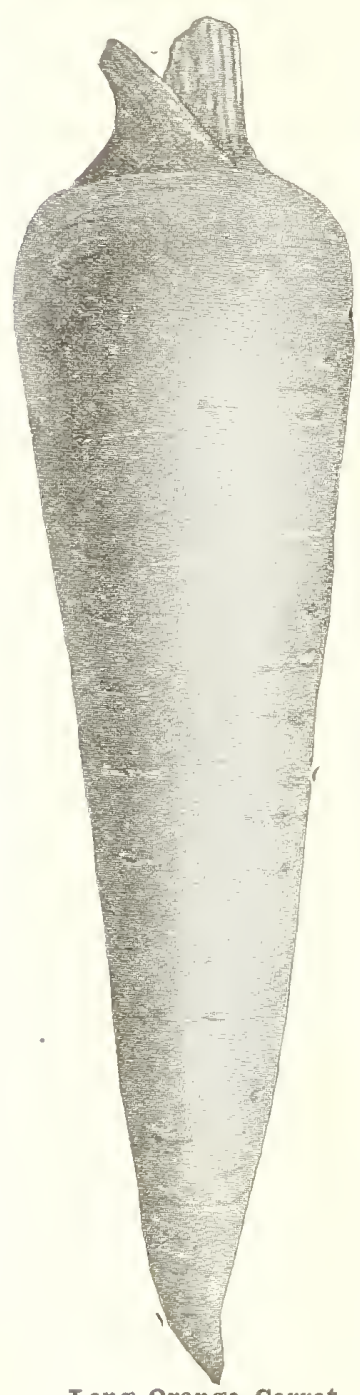

CUITURE. Carrots, to grow to perfection, require a deep, rich, sandy loam, well pulverized and deeply cultivated. For an early crop sow in May and June in drills about 1 foot apart. thinning out to 4 inches in the row; sow for winter crop in June and July. It is very important to tread the rows firmly after sowing the seed.

\section{Early Golden Ball, or}

French Forcing. A very desirable variety for forcing and also supply ing early roots for open ground. The small round roots $m$ eas u re about $1 \frac{1}{2}$ inches in diameter, are smooth, tender and of good flavor. Pkt. 5 and 10 cts.; oz. 15 cts.; I/4 lb. 30 cts.; lb. $\$ 1.00$, postpaid.

\section{Danver's Half Long}

Orange. A handsome cylindricalshaped carrot of good size. It is of rich, dark orange color, grows to a large size, is smooth and the flesh very close in texture, with little core. It is a first-class carrot for all soils, and it is claimed that under good cultivation it will yield the greatest weight per acre with the smallest length of root of any now grown. Pkt. 5 and $10 \mathrm{cts}$.; oz. 15 cts.; I/4 lb. 25 cts.; lb. 75 cts.

AC61. Chantenay, or Model.

Broad stump roots measure 5 inches long and 3 inches in diameter at shoulder. Roots are smooth, flesh teuder and fine grained; color deep orange. A most popular variety in all markets. Pkt. 5 and 10 cts.; oz. 15 cts.; I/4 lb. 25 cts.; lb. 75 cts., by mail postpaid.

134. Ox-Heart Selected Stock A thick carrot, 5 inches long and very blunt at the lower extremity. It grows very rapidly and the roots attain a weight of more than a pound. It is tender, and of a deep red color, and is a variety we can recommend to all market gardeners. Pkt. 5 and $10 \mathrm{cts}$; 0 z. $15 \mathrm{cts}$.; $1 / 4$ lb. $25 \mathrm{cts}$; lb. $75 \mathrm{cts}$.

161. Half Long Stump-Rooted Nantes Strain. One of the most popular sorts. The half-long roots measure 6 inches long by $1 \frac{1 / 2}{2}$ inches in diameter. Flesh tender and sweet; color rich orange. Pkt. 5c and 10c; oz. 15c; 1/4lb. 25c; lb. 75c.

A87. Half Long Pointed. A well-known strain; productive. Pkt. 5 and $10 \mathrm{cts}$; $0 \mathrm{z} .15 \mathrm{c}$; I/4 lb. 25c; lb. $75 \mathrm{c}$.

AC5. Pride of the Market. This beautiful, $\mathrm{m}$ e d i u $\mathrm{m}$ size, pointed-root carrot is just what gardeners want for an early crop. In color, earliness, size, form and shape it excels all uther sol's. Pkt. 5 and 10 cts.; oz. 15 cts.; I/4 lb. $30 \mathrm{cts}$.; lb. $90 \mathrm{cts}$.

C61. Early Rubicon. A half long Orange, s t u m prooted Carrot, of a beautiful, deep-red orange color. It is earlier than Danvers, about the same length, but heavier and thicker at the shoulder, making it more productive. It is a wonderfully heavy cropper, producing 3 to 4 tons to the acre under good culture. Pkt. 5 and 10 cts.; oz. 15 cts.; I/4 lb. 25 cts.; lb. 75 cts.

Three Ounces of Seed to 100 Yards; Four Pounds to the Acre.

\section{Nichol's Long} Orange Improved. One of the most desirable either for grarden or field culture. It grows to large size, fair specimens average 12 ins in length and 3 inches in diameter at the top. All who have cat t I e should raise a surplus of this carrot for feeding milch cows during the winter. Pkt. 5 and 10 cts.; $0 z$. 15 cts.; I/4 lb. 25 cts.; lb. $75 \mathrm{cts}$.

\section{C5. Henderson's}

Intermediate. One of the best main crop carrots. It is noted for its smoothness of shape, its tenderness of flesh and beauty of color. It is free from any coarse, rank flavor. Pkt. 5 and 10 cts.; oz. 15 cts.; $1 / 4$ lb. 25 cts.; lb. 75 cts.

\section{Early Scarlet, or} Dutch Horn. An excellent table variety, for planting out of doors, with orange red roots about three inche oz. $15 \mathrm{cts}$.; I/4 lb. $30 \mathrm{cts}$.;

lb. $90 \mathrm{cts}$

Early Sunbeam. Bolgiano's New, Extremely E a r ly Carrot. This beautiful, delicious, exceptionally early forcing Carrot comes at the time of the rear when new vegetables are most appreciated and enjoyed. Be sure to plant some. Pkt. 5 and 10 cts.; oz. 15 cts.; I/4 lb. 30 cts.; lb. 90 cts.

Scarlet Beauty Carrot. A handsome and prolific Carrot. Rich deep scarlet in color. In length, between Long and Half Long Orange. Very straight roots. Very little foliage for size of roots, Delicious flavor. Heavy yielder. Uniform size. Often $2 \frac{1}{2}$ to 3 inches at the top, and 10 to 12 inches long, Pkt. 5 and 10 cts.; oz. 15 cts.; I/4 lb. 30 cts.; lb. 90 cts.

\section{St. Valery, Long Red.}

Color, orange-red. Roots larce and handsome, intermediate in $\mathrm{s}$ h a p e between Danvers and long $\mathrm{Or}$ a $\mathrm{n} \mathrm{g} \mathrm{e}$. Pkt. 5 and $10 c$; oz. $15 \mathrm{c} ; \mathrm{I} / 4 \mathrm{lb}$. $25 \mathrm{c}$; Ib. $75 \mathrm{c}$.

\section{Large, White Belgian Carrot.} Produces 1 a r ge roots 4 inches in diameter at $\mathrm{t} \mathrm{h} e$ top and 10 ins. in length. It has a white skin a $n d$ flesh. These Carrots a re grown for feeding stock during the winter; they $\mathrm{k}$ e e $\mathrm{p}$ stock in fine condition. Pkt. 5c; oz. $10 c ; \quad \mathrm{r} / 4 \mathrm{lb}$. $20 \mathrm{c} ; 1 \mathrm{lb} .60 \mathrm{c}$.

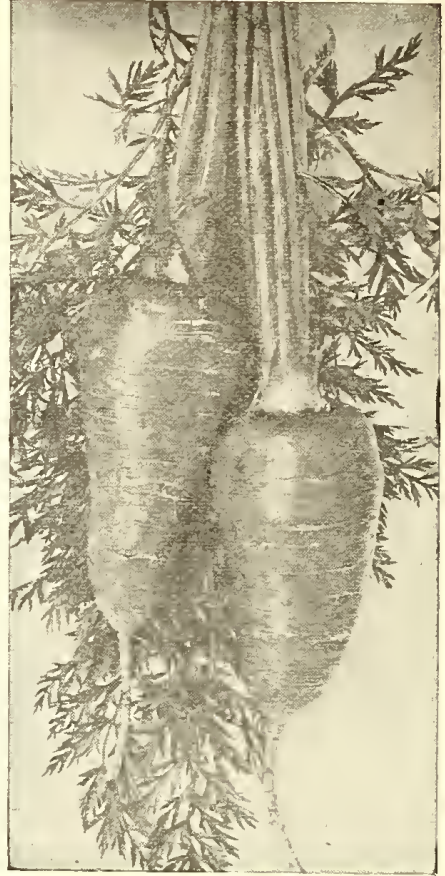

Danver's Half Iong Carrot.

Pkt. 5 and 10 cts.; 


\section{CELERY}

One Ounce Will Produce About 3000 Plants, and Sow About 200 Feot of Row.

CULTURE. Sow the last of March or early in April in an open border, in rich, mellow ground, in shallow drills, watering freely in dry weather. Cut the tops off once or twice before planting out to make them stoeky. Wher the plants are $5 \mathrm{ol}^{\circ} 6$ inches high transplant the dwarf varieties 5 feet and taller sorts 4 feet between rows; plant 6 inehes apart in the row. Cultivate well, and when lalge enough blanch by earthing up. The first operation is that of "handling" generally done the beginning of September. After the soi that of handing generally done the beginning of september a plant by hand as to keep the leaves firm in an upright position and prevent spreading. When the plants have beeome "set" in an up
for early use, they should be "banked."

\section{French Golden Self-Blanching. This is the best early celery in cultivation. Since its intro} duction, in 18\$4, it has been steadily increasing in sales, until now it is the main early celery raised by market gardeners. The beautiful appearance of the plant, with its close habit, compact growth and straight, vigorous stalks, is faithfully shown in the illustration. The ribs are perfectly solid, crisp, brittle and of delicious flavor. It is self-blanching to a very remarkable degree, for without banking up or any covering whatever. even the outer ribs become a handsome, fresh, yellowish white color. The heart is large and solid and of a beautiful, rich, golden yellow color. Pkt. 5 and 10 cts.; oz. 60 cts.; 1/4 lb. \$2.25; lb. \$8.00.

Golden Self-Blanching. American grown. Pkt. 5 and 10 cts.; oz. 30 cts.; $1 / 4$ lb. $\$ 1.00 ;$ lb. $\$ 3.50$.

185. Easy Blanching. This splendid new variety is dwarf and compact in habit; light-green foliage. It is very easily blanched and might be termed second early, following Golden SelfBlanching. For winter and spring use, it is a splendid keeper. The flavor is first class, while the stalks are pure white, heavy and crisp. Pkt. 5 and 10 cts.; oz. 30 cts.; $1 / 4$ lb. $\$ 1.00 ;$ lb. $\$ 3.50$.

71. White Plume. While very early and easy to blanch will not keep long after taken from the trenches. As the stalks become ready for use they take on a pure white, even though not earthed up. The hearts are better if the stalks are slightly earthed up. Pkt. 5 and 10 cts.; oz. 15 cts.; I $/ 4$ lb. 50 cts.; lb. $\$ 1.75$.

Bolgiano's Sweet Nut Celery. For home gardens and nearby markets Bolgiano's New Celery, "Sweet Nut," is the most delicious, sweet, nutty, crisp celery that has ever been offered to the public. It is absolutely solid, a most excellent winter keeper, of vigorous, sturds growth, making fine, large, solid stalks, with a large, full, creamy-yellow heart. Pkt. 5 and 10 cts.; oz. 15 cts.; $1 / 4$ lb. 50 cts.; lb. $\$ 1.75$.

135. Bolgiano's Golden Heart. This is the old standard sort which has satisfied gardeners these many years. It is crisp, solid. handsome, the most excellent flavor, with a beautiful golden heart. Pkt. 5 and 10 cts.; oz. 15 cts.; I/4 lb. 50 cts.; lb. $\$ 1.75$.

C11. The Shumacher. The stalks of this splendid variety grow to an immense size, and are perfectly solid and crisp. It has a firm and beautiful golden heart, and the flavor is first class. Pkt. 5 and 10 cts.; oz. $15 \mathrm{cts}$.; 1/4 lb. 50 cts.; lb. $\$ 1.75$.

46. Winter Queen. Beautiful in appearance, of close habit and compact growth, and blanches to an attractive cream white. Ribs perfectly solid, crisp, and of a delicious nutty flavor. Pkt. 5 and 10 cts.; oz. 20 cts.; $1 / 4$ lb. 60 cts.; lb. $\$ 2.00$.

15. Giant Pascal. The stalks are very large, thick, solid, crisp and a rich nutty flavor, free from any taste of bitterness. Blanches very easily and quickly and retains its freshness a long time after being marketed. The heart is a golden yellow, very full and attractive. Pkt. 5 and 10 cts.; oz. 15 cts.; $1 / 4$ lb. 35 cts.; lb. $\$ 1.25$.

20. Boston Market. Forms a cluster of heads and should be blanched by earthing up. A popular market garden variety. Pkt. 5 and 10 cts.; oz. 15 cts.; $1 / 4$ lb. 50 cts.; lb. $\$ 1.50$.

29. Hartwell's Perfection. Magnificent, large, goldenyellow heart, of superior quality, excellent winter market sort. Pkt. 5 and $10 \mathrm{cts}$; 0 z. 15 cts.; $1 / 4 \mathrm{lb} .40 \mathrm{cts}$.; $1 \mathrm{~b} . \$ 1.25$.

67. Flavoring Celery. Cannot be used for growing purposes, but is an excellent spice for soups, salads, etc. 2 ozs. $10 \mathrm{cts}$; $\mathrm{r} / 4 \mathrm{lb} .20 \mathrm{cts}$; lb. $50 \mathrm{cts}$.

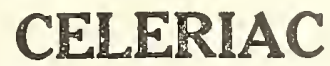

(Turnip=Rooted Celery)

CUITURs. Sow the seed the same season as eelery. Transplant young plants to moist, rich soil in rows 2 feet and 6 inehes apart in the row.

23. Large Smooth Prague. A new and quite distinct sort, the roots being very smooth, large, round. Of a very distinctive flavor; roots may be boiled or used in flavoring other dishes. Pkt. 5 and 10 cts.; oz. $15 \mathrm{cts}$.; 1/4 lb. $50 \mathrm{cts.;}$ lb. $\$ 1.75$.

Giant French. Pkt. 5 and $10 \mathrm{cts}$.; $0 \mathrm{z} .20 \mathrm{cts}$.; $\mathrm{I} / 4 \mathrm{lb}$. $60 \mathrm{cts}$.; Ib. $\$ 2.00$.

\section{CRESS}

CUITURב. Sow thiekly in shallow drills every 2 or 3 weeks, It should be cut often, and it will eontinue to grow. It is useful not only for salad, but for the breakfast table and for garnishing. True Water Cress should be sown in damp soil; or if a stream of water can be utilized they will be much finer. They will also
thrive well in damp hotbeds. Rightly managed, their culture is very profitable. To obtain early salad, it is a good plan to sow with Water Cress seed a strip 4 inehes wide on the outer margin of a hotbed, inside the frame, where it is always cool.

21. True Water. It thrives when its roots and stems are submerged in water. It is one of the most delicious of small salads. Pkt. 5 and 10 cts.; 0z. 35 cts.; 1/4 lb. \$1.15; lb. $\$ 4.00$.

215. Wild Garden. Largely used for pork salad; has a delicious pungent taste. Pkt. 5 and 10 cts.; 0 z. 15 cts.; $1 / 4$ lb. 45 cts.; lb. $\$ 1.50$.

Pepper Grass. The seed should be sown in drills about 16 inches apart on very rich ground, and the plants well cultivated. Pkt. 5 cts.; oz. 10 cts.; $1 / 4$ lb. $25 \mathrm{c} ; 1 \mathrm{lb} .75 \mathrm{c}$. 
ALL OF OLR CORN IS EASTERN GROWN

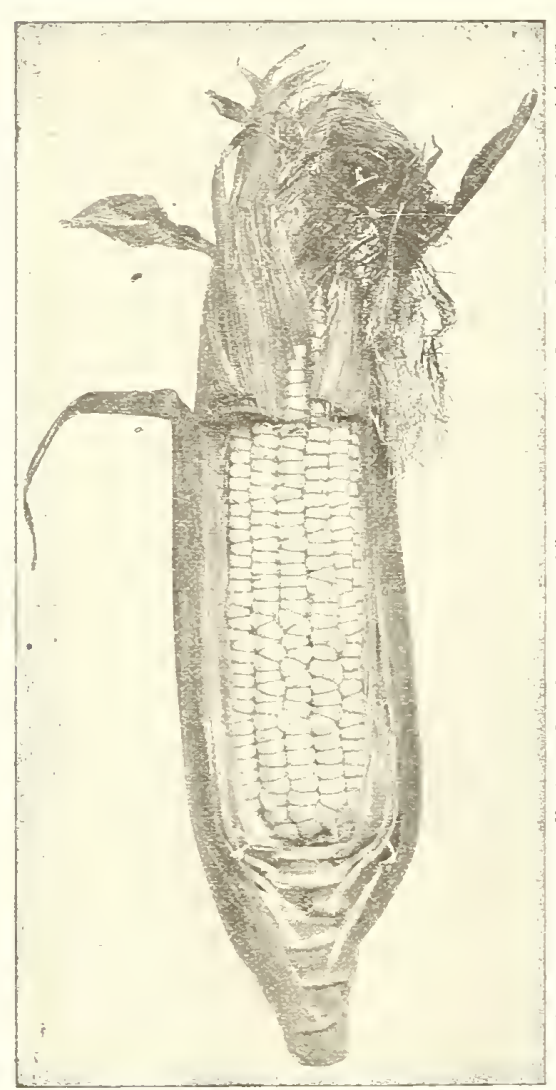

Extra Early Ideal Sweet Corn.

\section{Extra Early Varieties}

Extra Early Ideal. The earliest. best, most profitable - corn erer iutroduced. Large ears, sweet. delicious flaror, tender and extremely early. See also page 4. Pkt. 10 cts.; pt. 20 cts.; qt. 35 cts.; gal. \$1.00; peck, \$1.75; bushel, \$6.00.

Bolgiano's Extra Early Harvester. This is the best Sugar Corn that has erer been placed on the market. It is sereral dars earlier than the "Golden Bantam," sweeter faror, ears larger and pure white in color. It is a rapid grower, medium in height, large rielder, 3 to 4 ears to the stalk. 6 to 7 inches long. A wonderful corn for early home use. See page 4. Pkt. 10 cts.; pt. 25 cts.; qt. 45 cts.; peck, $\$ 2.85$; bushel, $\$ 10.50$.

Bolgiano's New "Cream and Honey" Sweet Corn. Extremely earls, most delicious flaror, exceptionally fine qualits. Should be tried by every wide-awake market gardener and in home garden where the "best" of erersthing is enjored. Pkt. 10 cts.; pt. 20 cts.; qt. 35 cts.; peck, $\$ 1.75$; bushel, $\$ 6.00$.

\section{California Golden Country} Gentleman Corn. This is a wonderful combination of "Cream and Honey" Sugar Corn and the wellknown "Country Gentleman" Sugar Corn. Could rou possibly think of auything more delicious than the good points of these two corns combined into one? Don't take chances of forgetting it-send in your order today certain. Pkt. 10c; pt. 25c; ct. $40 \mathrm{c}$; peck $\$ 2.15 ;$ bushel $\$ 7.50$.

\section{SWEET CORN}

\author{
ALL OF OUR CORN IS \\ EASTERN GROWN
}

\section{Golden Bantam.}

One of the sweetest corns grown. It ity. In all in raliety of exceptionally good qualspects it is a gem-iu size of plant, ear and account of its sinall sell adapted to small gardens on of its excessire cropping ability on a giren area, and to all because of its superb quality and luscious satisfing flaror. Pkt. 10 cts.; pt. 20 cts.; qt. 35 cts.; gal. $\$ 1.00$; peck, $\$ 1.75 ;$ bushel, $\$ 6.00$.

Adams' Extra Early. Largel grown for earls market. Pkt. 10 cts.; pt. 15 cts.; qt. 25 cts.; peck, $\$ 1.60$; bushel $\$ 5.50$. Ears, 75 cts. per dozen.

Second Early Adams' Corn. Ears are all larger and later thau Adams' Extra Early. Pkt. 10 cts.; pt. 15 cts.; qte. 25 cts.; peck, $\$ 1.40$; bushel, $\$ 4.50$. Ears, 75 cts. doz.

Premo. Extra early : rery large ears ; fiue qualits. Pkt. 10 cts.; pt. 15 cts.; qt. 25 cts.; gal. 70 cts.; peck $\$ 1.60$; bushei, $\$ 5.50$.

Mammoth White Cory. Stalks grow four feet high, geuerally bearing two large, finels shaped ears, fit for use in about serenty dars. Ears are twelre rowed, 6 to 7 inches loug. rers srmmetrical and handsome. Pkt. 10 cts.; pt. 15 cts.; qt. 25 cts.; 4 qts. 90 cts.; peck, $\$ 1.60 ;$ bus. $\$ 5.50$.

Golden Evergreen. A splendid rariets to follow Bantam. The ears are larger and better filled. Pkt. 10 cts.; pt. 25 cts.; qt. 40 cts; gal. $\$ 1.25 ;$ peck, $\$ 2 ;$ bus. $\$ 7.00$.

Howling Mob. This splendid flarored sweet corn grows 4 to 5 feet high, producing two good ears to the stalk, which measures 7 to 9 inches in length. In season this corn ripens about 4 to 6 dass later than White Cory. Its unusual name arose from the fact that the Market Gardener who origiuated this strain had so many people crowded about his stand that it was realls a mob calling loudly for his corn. Pkt. 10 cts.; pt. 15 cts.; qt. 25 cts.; pk. $\$ 1.60$; bus. $\$ 5.50$.

\section{Second Early Varieties}

Peep-o-Day. The two points of this remarkable Corn are its extraordinars earliness and unparalelled sweetness. So marked is its sweetness and delicacy of flavor that many of our customers plant Peep-o-Day exclusirely, arranging the plantings a few days apart so as to have this delicious Corn throughout the season. The stalks bear from 3 to 5 ears each, and the growth being dwarf-about 4 feet. Pkt. 10 cts.; pt. 20 cts.; qt. 35 cts.; gal. \$1.00; peck, \$1.75; bushel, $\$ 6.00$.

Extra Early Evergreen. Ripens about 10 days earlier and is equally as good. It is a splendid variety to come in between the early and late sorts, and is destined to become popular. Pkt. 10 cts.; pt. 15 cts.; qt. 25 cts.; gal. 90 cts.; peck, $\$ 1.60 ;$ bushel, $\$ 5.50$. Ears, $\$ 1.00$ per dozen.

Early Mammoth Sugar. Sweet, delicate flaror, producing a large ear and a small sized cob. which fills out to the end perfectly. Pkt. 10 cts.; pt. 15 cts.; qt. 25 cts.; gallon, 90 cts.; peck, $\$ 1.60$; bushel, $\$ 5.50$.

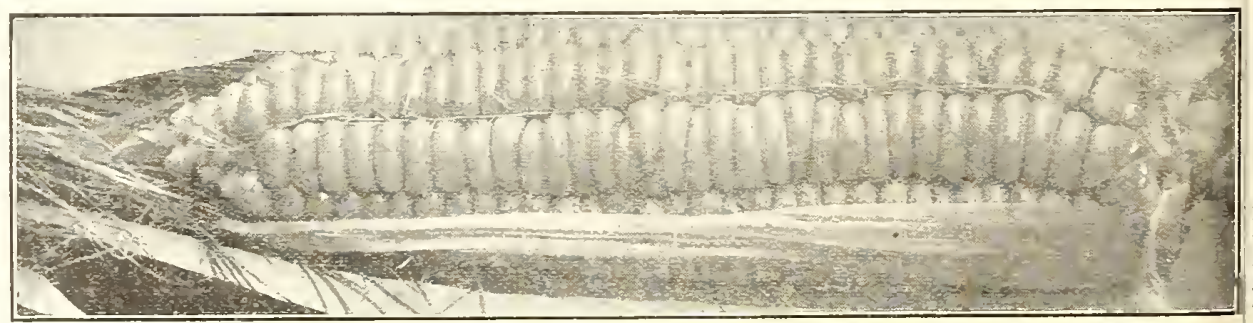

Golden Bantam. 


\section{GENERAL AND LATE CROP SUGAR CORN}

\section{Snow White Evergreen.}

The most valuable sweet corn for main (rop. It has the ideal qualities of the Stowell's Hvergreen Corn, only it is pure white, making it the most desirable late corn for market and home gardencrs. Pkt. 10 cts.; pt. 15 cts.; qt. 25 cts.; gal. 90 cts.; peck, $\$ 1.60$; bushel, $\$ 5.50$.

Stowell's Evergreen. This is not only the most celebrated, but the most popular of all the varieties, although not an early sort. It is, without exception, the best for table use of the en-

tire lot, although quite late.

Some may observe they have tried it and found it not equal to the ordinary sugar. To such we say you have not had the pure stock, as no variety degenerates so quickly, unless the grower is exceedingly careful. Pkt. 10 cts.; pt. 15 cts.; qt. 25 cts.; gal. 85 cts.; peck, $\$ 1.50 ;$ bushel, $\$ 5.00$. Ears, $\$ 1.00$ per dozen.

Shoe Peg, or Ne Plus Ultra. An old standard favorite, of fine flavor, deep grains, and good production. Pkt. 10 cts.; pt. 20 cts.; qt. 35 cts.; gal. $\$ 1.00 ;$ peck, $\$ 2.75$; bushel, $\$ 7.00$.

Late Mammoth. A late sort on account of its immense size, producing the largest ears of any variety. These measure up to 14 inches in length, and are well filled with large, broad, white kernels, which are sweet, tender and delicious. Usually there are 16 to 18 rows to the ear. The stalls are very large, about 8 feet high, and productive. Pkt. 10 cts.; pt. 20 cts.; qt. 35 cts.; 4 qts. $\$ 1.00$; peck $\$ 2.00$; bushel $\$ 6.00$. Ears, $\$ 1.00$ per dozen.

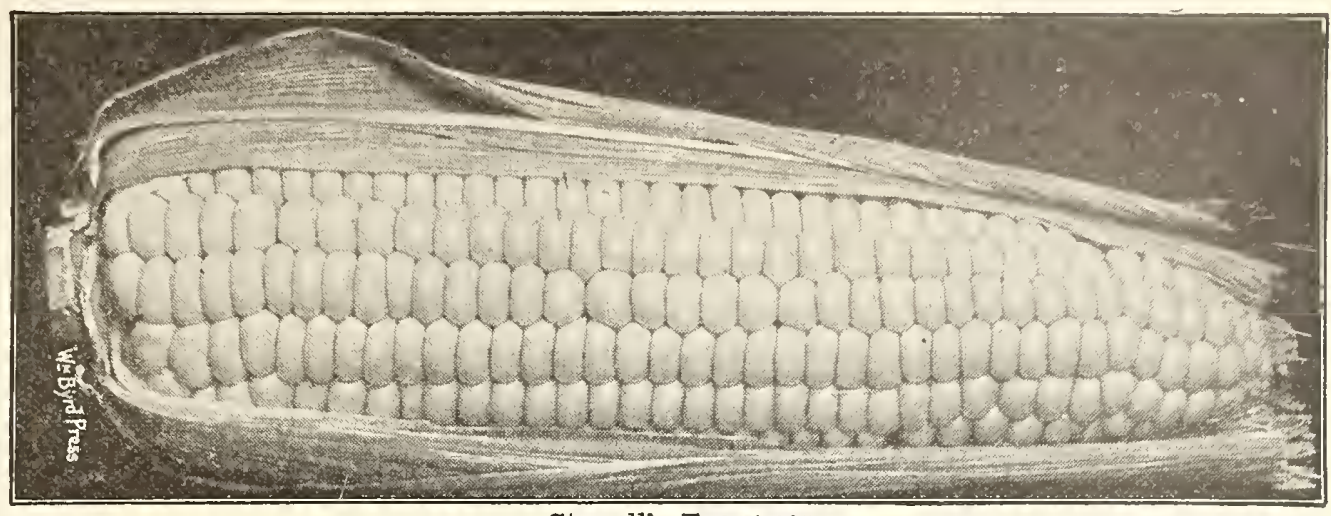

Stowell's Evergreen.
Country Gentleman. The deep shoe - peg kernels art placed irregularly, but compactly, upon the cob. It is ver? prolific, generally bearing 3 to 5 ears to the stalk, and ma. tures a little before Stowell's Evergreen, being sweeter anc more sugary to the taste even than that well known stand. ard of quality. Pkt. 10 cts.; pt. 20 cts.; qt. 35 cts.; gal $\$ 1.00$; peck, $\$ 1.75$; bushel, $\$ 6.00$. Ears, $\$ 1.25$ per doz

Hickox Improved. Handsome ears, very white and $o^{*}$ very rich flavor. Pkt. 10 cts.; pt. 15 cts.; qt. 25 cts. peck, $\$ 1.60$; bushel, $\$ 5.50$.

Black Mexican Sugar. Very sweet and tender wnes ready for table; grain is black. Pkt. $10 \mathrm{cts}$.; pt. $25 \mathrm{cts}$. qt. 40 cts.; gallon, $\$ 1.25$; peck, $\$ 2.00$; bushel, $\$ 7.00$.

202. Rice Pop Corn for Popping or Seed. A v e r r handsome variety; ear's short; kernels long, pointed; ver? prolific; no variety of pop corn is superior to this for poy ping. 15 cts. per Ib.; if by mail, 20 cts. per Ib., postpaid ail orders for Corn unless shipped by express.

\section{ENDIVE}

One Ounce Will Sow 150 Feet of Row.

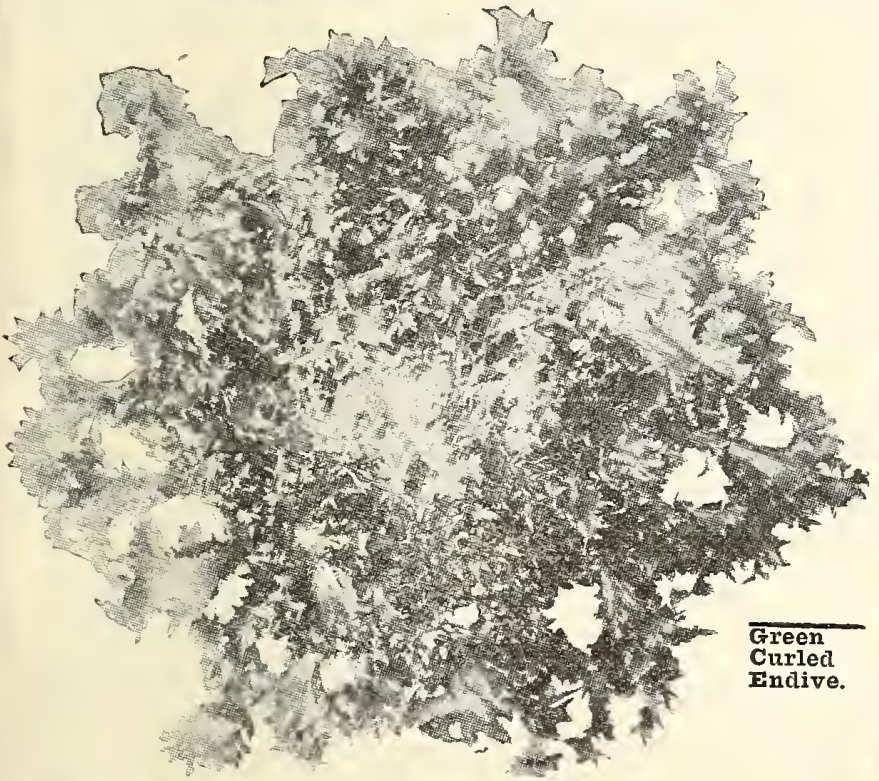

Endive is one of the best salads for fall and winter use. Sow for an early supply about the middle of April. As it is used mostly in the fall months, the main sowings are made in June and July. Plant one foot apart each way. When the plant has attained its full size gather up the leaves and tie them by their tips in a conical form. This excludes the light and air from the inner leaves until blanched.
43. Green Curled.

vation. Much more beautiful and sort. Pkt. 5 and $10 \mathrm{cts}$; 0z. $15 \mathrm{cts}$.; 1/4 lb. $30 \mathrm{cts}$; $1 \mathrm{lb} . \$ 1$.

162. White Curled. As the color of the leaves is a ligh golden yellow, little or no blanching is required. Very easily grown, and plants may be gathered for use at any time Pkt. 5 and 10 cts.; oz. 15 cts.; $1 / 4$ lb. $35 \mathrm{cts}$.; lb. $\$ 1.25$.

C37. Escarole, or Broad-Leaved Batavian. Leaves : pale green; requires very little blanching. More productivt than green curled. Forms large heads of broad thick leaves Pkt. 5 and 10 cts.; 0z. 15 cts.; I/4 lb. $30 \mathrm{cts}$.; lb. $\$ 1.00$.

\section{COLLARDS}

A great many people look upon the lowly collard, or "Georgia Cabbage," as some jokingly refer to it, as some. thing not worth while growing. Now there are thousands of collard patches scattered over the South, and most South. ern people like them. The collard is an old-time favorite. adapted to all parts of the South, and as a producer of "greens" for boiling in winter and spring it has no equal. It will pay you to have a collard patch just to give you cows an occasional taste of "green stuff." Sow any time up to September 1 st.

C50. Southern, or Georgia. This variety is the old. time favorite. Stands all sorts of adverse conditions with. out injury. It is very hardy, standing winters as far north as Atlanta. In many places where the soil is too poor to grow cabbage, the collard grows easily and makes a good substitute for cabbage. Pkt. $5 \mathrm{cts}$; oz. $10 \mathrm{cts}$; $1 / 4 \mathrm{lb}$ 20 cts.; lb. $50 \mathrm{cts}$. 


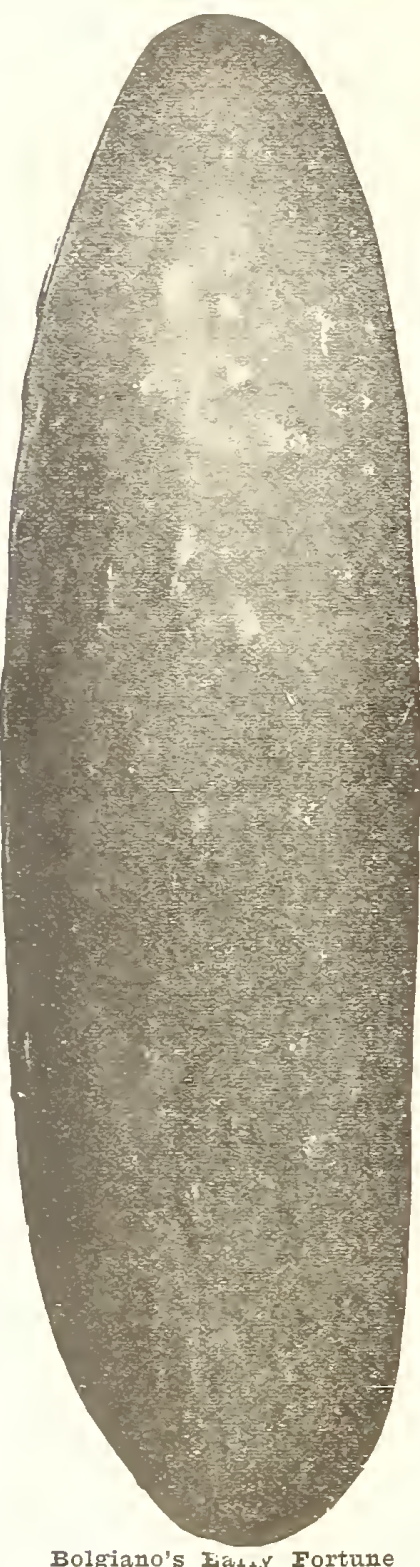

Bolgiano's Eansy Fortune

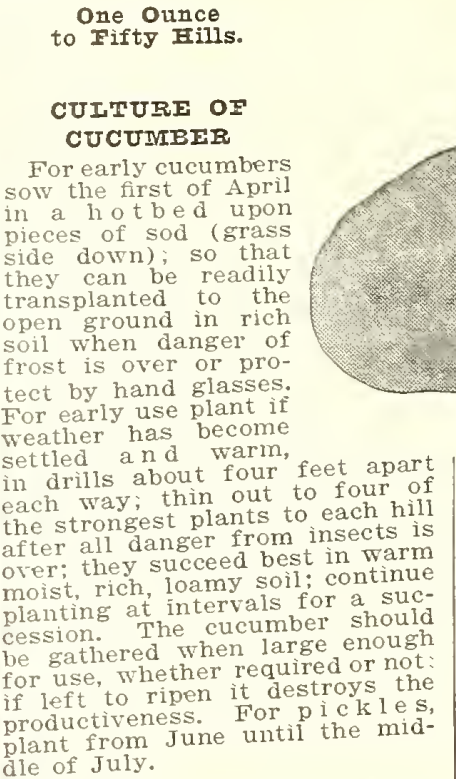

Bolgiano's Early Fortune.

By far the earliest and best cucumber for table, market or shipping purposes. In color, Eatrly Fortune is rich, attractive, deep green, which is retained during a much longer period of growth than any other variety. Its form is so resular and the size of all the fruits so nearly the same that growers marvel at the purity and trueness of her stalk. The flarol is delicately refreshing, entirely free from bitterness, exceedingly crisp and brittle. making it an ideal slicing cucumber. Pkt. 5 and 10 cts.; oz. 15 cts.; $1 / 4$ lb. 30 cts.; lb. $\$ 1.00$.

Bolgiano's Crystal Springs Cucumber. Pkt. 5 a n d 10 cts.; oz. 15 cts.; $1 / 4$ lb. 30 cts.; lb. $\$ 1.00$.

Bolgiano's Prosperity. Iutense, rich, deep green color retained longer tha ans other cucumber; the flesh sparkling white. The earliest white spine cucumber. Most refreshing aud delightful flavor. Uuiformly large, symmetrical fruit. Burs no culls. Tines are vigorous, healthy and mildew-proof. Pkt. 5 and 10 cts.; oz. $15 \mathrm{cts}$; $1 / 4 \mathrm{lb}$. 30 cts.; lb. $\$ 1.00$.

73. Arlington White Spine. Our selected strain of this far the best type on this or any other market. We have this seasou gromn only from seed produced from cucumbers that Were simpli pelfect in eTery respect. Dark, rich green color and holding its color long after other sorts hare gone rellow and become unsuited for the market. A crop of our stock of Arlington White suine is sure to make trade for any market garden, and for home use it surpasses all other kinds. As a shipper it has few equals. Pkt. 5 and 10 cts.; $0 z .15$ cts.; I/4 lb. $30 \mathrm{cts}$; lb. $\$ 1.00$.

109. Davis Perfect. Daris Perfect Cucumber resembles a hot-house cucumber so closely that it is difficult for some dealers to tell the difference. Equally good for hot-house or outdoor culture. It is ideal in shape, rich, dark green color, uniform and regular in size. Pkt. $\mathbf{5}$ and $\mathbf{1 0}$ cts.; 0z. 15 cts.; I/4 lb. 30 cts.; lb. $\$ 1.00$.

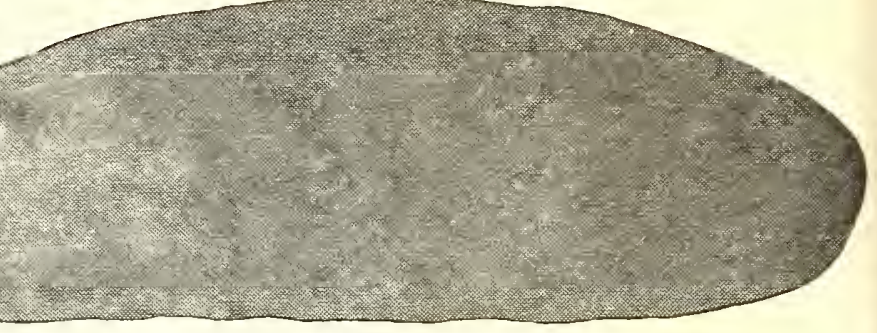

Bolgiano's Prosperity Cucumber.

186. Klondike. This valuable rariety is one of the best for slicing, and will produce cucumbers similar in appearance to the hot-house grown specimen. The color is rich dark green, aud the fruits grow to a uniform size, measuring about 7 inches in length and 2 iuches thick when in good condition for use. It matures early. Pkt. 5 and 10 cts.; 0z. 15 cts.; I/4 lb. 30 cts.; lb. $\$ 1.00$.

86. White Spine Extra Early. Au extra-early strain of the popular White Spine. Pkt. 5 and 10 cts.; oz. 15 cts.; I/4 lb. $30 \mathrm{cts}$.; lb. $\$ 1.00$.

A86. Evergreen. Tery early and prolific; deep green color. Pkt. 5 and 10 cts.; oz. 15 cts.; $1 / 4$ lb. 30 cts.; lb. $\$ 1.00$.

Henderson's Perfection White Spine. This cucumber is rery much the same type as the Early Fortune. Has great quautities of extra fancy dark green fruit. Pkt. 5 and 10 cts.; 0z. 15 cts.; $\quad 1 / 4$ lb. 35 cts.; lb. $\$ 1.00$.

The Wonderful New Lemon Cucumber. We are safe to predict that the Lemou Cucumber will become a great farorite as a table delicacy. It is an excellent shipper, and pickled as a gherkin it is delicious. Pkt. 5 and $\mathbf{1 0}$ cts.; oz. 15 cts.; $1 / 4$ lb. 45 cts.; lb. $\$ 1.50$.

156. Long Green. It is rigorous aud productive. The mature fruit is almost 12 inches long. The skin is a deep green, and the flesh is solid, crisp aud of fine quality. Especially recommended for pickling. Pkt. 5 and 10 cts.; oz. 15 cts.; $1 / 4$ lb. 35 cts.; lb. $\$ 1.25$.

Early Green Cluster Cucumber. This is an extra early pickling or frame variety, being the earliest cucumber of practical use. They will produce fruits ten days earlier than the earliest slicing varieties. Pkt. 5 and $10 \mathrm{cts.;}$ oz. 15 cts.; I/4 lb. $30 \mathrm{cts}$.; lb. $90 \mathrm{cts}$.

Early Frame, or Early Short Green. Desirable for producing pickles of medium size and fine quality. Pkt. 5 and 10 cts.; oz. 15 cts.; $1 / 4$ lb. 35 cts.; lb. $\$ 1.00$.

Japanese Climbing. Used as a beautiful viue and also for its fruit. Pkt. 5 and 10 cts.; oz. 15 cts.; 1/4 lb. 45 cts.; lb. $\$ 1.50$.

107. Jersey Pickle. Fine green color. Used for pickling almost entirely. Pkt. 5 and $10 \mathrm{cts.;} 0$. $15 \mathrm{cts}$.; 1/4 lb. 30 cts.; lb. 90 cts.

190. Snow's Pickling. An early maturing, гегy small, dark green cucumber, cylindrical, square ended, and very popular with growers of small pickles. Meets in all respects the requirements of those who want an ideal bottle pickle. Pkt. 5 and 10 cts.; oz. 15 cts.; I/4 lb. 35 cts.; lb. $\$ 1.00$.

Pittsburgh Famous Pickling. Bred to order by one of the most expert plant breeders for a concern who uses thousands of acres yearly. Pkt. 5 and 10 cts.; oz, 15 cts.; I/4 lb. 35 cts.; lb. $\$ 1.00$.

2. Gherkin, or Small Bur. Grown exclusively for pickling. Alrays pick when young and tender. Seed slow to germinate, requiring from 10 to 12 days. Pkt. 5 and 10 cts.; oz. 20 cts.; $\mathrm{r} / 4$ lb. 45 cts.; lb. $\$ 1.50$. 


\section{EGG PLANT}

One Ounce Egg-Plant Seed Will Produce About 500 Plants.

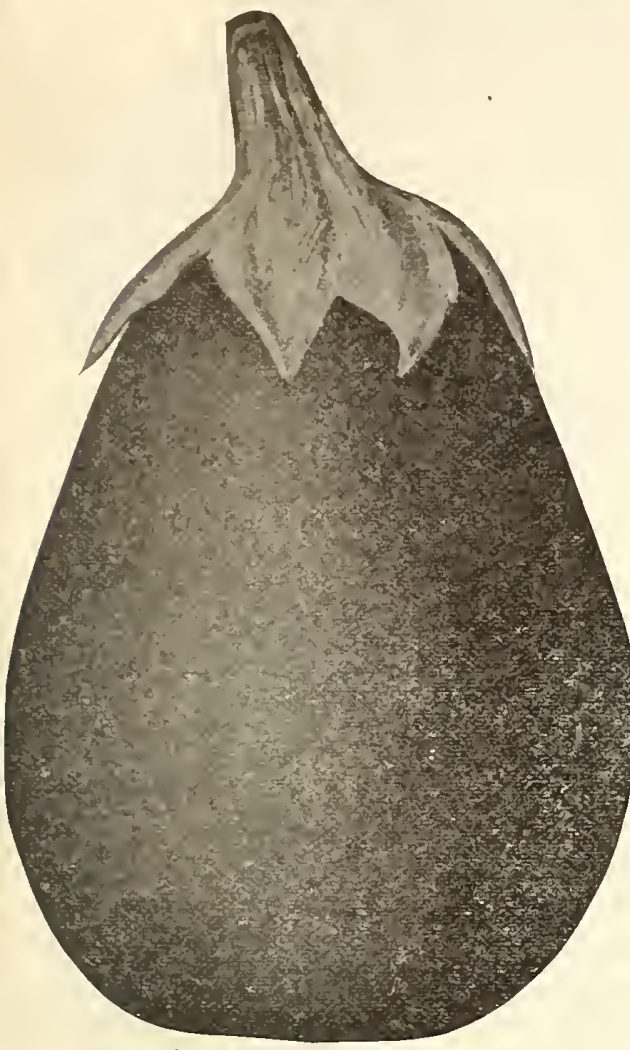

Florida Figh busn Egg-Plant.

fruits ale thick of most attractive form purplist-black-the satin gloss and rich coloring adding greatly to its beauty. The intensely brilliant coloring is uniform over the whole fruit and does not fade or change to a lighter color. Pkt. 5 and 10 cts.; oz. 45 cts.; I $/ 4$ lb. $\$ 1.35 ;$ lb. $\$ 5.00$.

216 . Forida High Bush. IIas proved of the greatest value to the Southern truckers and shippers. It is remarkable for its rigorous growth and productiveness; very hardy and will stand more cold weather than the New York Improved. The hot sun does not blight the blossoms. It grows from 3 to 4 feet high, erect and sturdy, free from thorns. Fruit is large, oblong in shape and purple; keeps its freshness and condition much longer than any other variety. Pkt. 5 and 10 cts.; 0z. $40 \mathrm{cts}$; $1 / 4$ lb. $\$ 1.25 ; \mathrm{lb}$. $\$ 4.50$.

\section{New York Improved Large Purple Thornless.}

In shape, color and size this Egg Plant is perfection; its rich, glossy, dark purple color, its beautiful form and large size make it most attractive for the markets and for shipping. Pkt. 5 and 10 cts.; 0z. 45 cts.; $1 / 4$ lb. $\$ 1.35 ;$ lb. $\$ 5$.

Bolgiano's Improved Large Purple Egg Plant. Perfect stock of improved Large Purple Egg Plant-purer, truer and better than has ever been offered before. It has a handsome shape, a fine, dark purple color, beautiful form, large size, and is uniform, making it attractive for shipping and market use. Pkt. 5 and 10 cts.; oz. 15 cts.; $1 / 4$ Ib. $\$ 1.35$; Ib. $\$ 5.00$.

California Tree Egg Plant. This variety is of medium size and extremely good shape. It resists drought and bad weather to a wonderful degree, partly on account of its strong, upright growth. It bears its fruit sometimes one or two feet above the ground, thus escaping liability to rot. Pkt. 5 and 10 cts.; oz. 50 cts.; I/4 lb. $\$ 1.85 ;$ Ib. $\$ 7.00$.

\section{KALE, or BORECOLE}

One Ounce Will Sow 200 Feet of Drill; 11/2 Pounds to the Acre. CULTUR. Kales are more hardy than cabbage, and make exeellent greens for winter and spring use, bcing improved by frost. Sow from May to June and cultivate same as eabbage.

121. Extra Dwarf Green Curled Scotch, or Norfolk. This is one of the best kales for spring sowing in the South for Northern markets. It is hardy and will remain over winter in any place where the temperature does not go below zero. The habit is very dwarf and spreading, and will rarely exceed 18 inches in height. 'The leaves are of dark green color, beantifully curled and produced in great abundanre. Pkt. 5 and $10 \mathrm{cts}$; 0 z. $15 \mathrm{cts.;} \mathrm{T/4} \mathrm{lb.} 30 \mathrm{cts}$; lb. \$1.

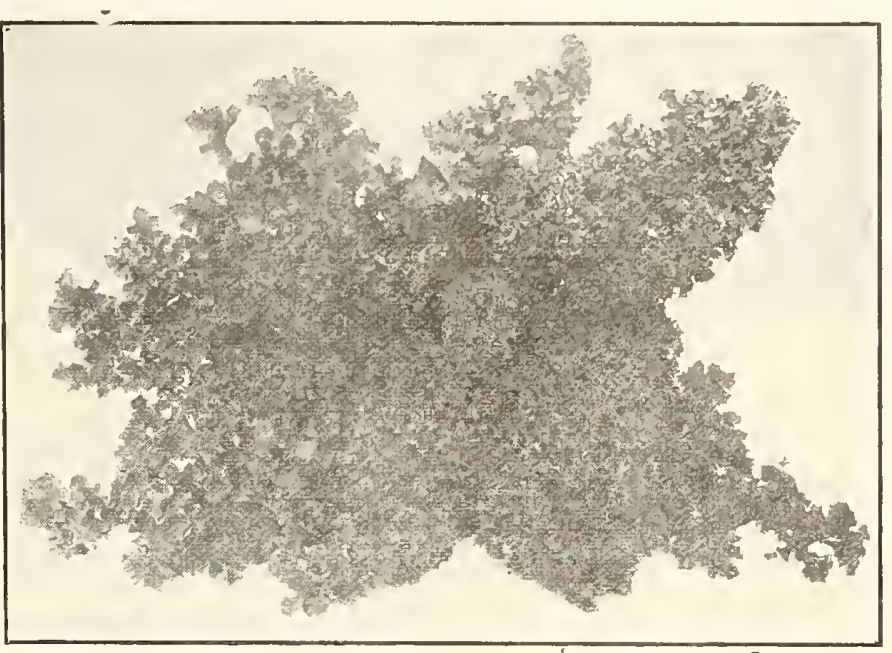

Dwarf Curlea Norfoli Kale.

66. Imperial Curly Long-Standing. A beautiful curled and crimped sort, of strong, vigorous habit; perfectly hardy, bright green color, and very attractive in appearance. It will stand longer without shooting to seed than any other variety. Pkt. 5c and 10c; oz. 15c; I/4 lb. 35c; lb. \$1.00.

69. Tall Scotch. Grows about two feet high with abundant dark green very curly leaves. Very hardy. Pkt. 5 and $10 \mathrm{cts}$; Oz. $15 \mathrm{cts}$; $1 / 4$ lb. 45 cts.; Ib. $\$ 1.50$.

Siberian Curled Kale. The green leaves are very large heavy curled on the edge, a fast grower, extremely hardy. Will stand until late spring without bolting. Pkt. 5 and 10 cts.; oz. 15 cts.; $1 / 4$ lb. 20 cts.; lb. 50 cts.

Curled Dwarf Green. Hardy; stands the frosts of our severest winter's, grows rapidly, dwarf habit, and is beautifully curled. Pkt. 5c and 10c; 0z. 15c; 1/4 lb. 25c; lb. $75 \mathrm{c}$.

New American Long Standing Extra Curled Kale. Beautiful green color, perfectly hardy. Will stand the coldest winter's. Very tender and can be cut for the market from early spring until late in season. Pkt. 5 and $10 \mathrm{cts}$.; oz. $15 \mathrm{cts}$.; I/4 lb. $30 \mathrm{cts}$.; lb. $\$ 1.00$.

\section{KOHL-RABI, or TURNIP- ROOTED CABBAGE \\ One Ounce Sows 300 Feet of Drill.}

CULTURE. Sow in spring, in rows 18 inehes apart, afterwar thinning the plants to 8 or 10 inches. If the weather is suitab!e the thinning may be planted, but it is considered difficul transplant. Keep the weeds down, and when the thickened stem. transplant. Keep the weeds down, and when the thickened stems above ground are 2 or 3 inches through they are fit to
should be used at once, being tough when old. Cook like

187. Early White Vienna. Then young and tender. and properly prepared for the table, it is almost erfuil to cauliflower. Besides, it is a certain crop, requiring no more care or cultivation than a crop of cabbage. For a fall crop sow in June. Pkt. 5c and 10c; 0z. 20c; 1/4lb. 65c; Ib. \$2.25 


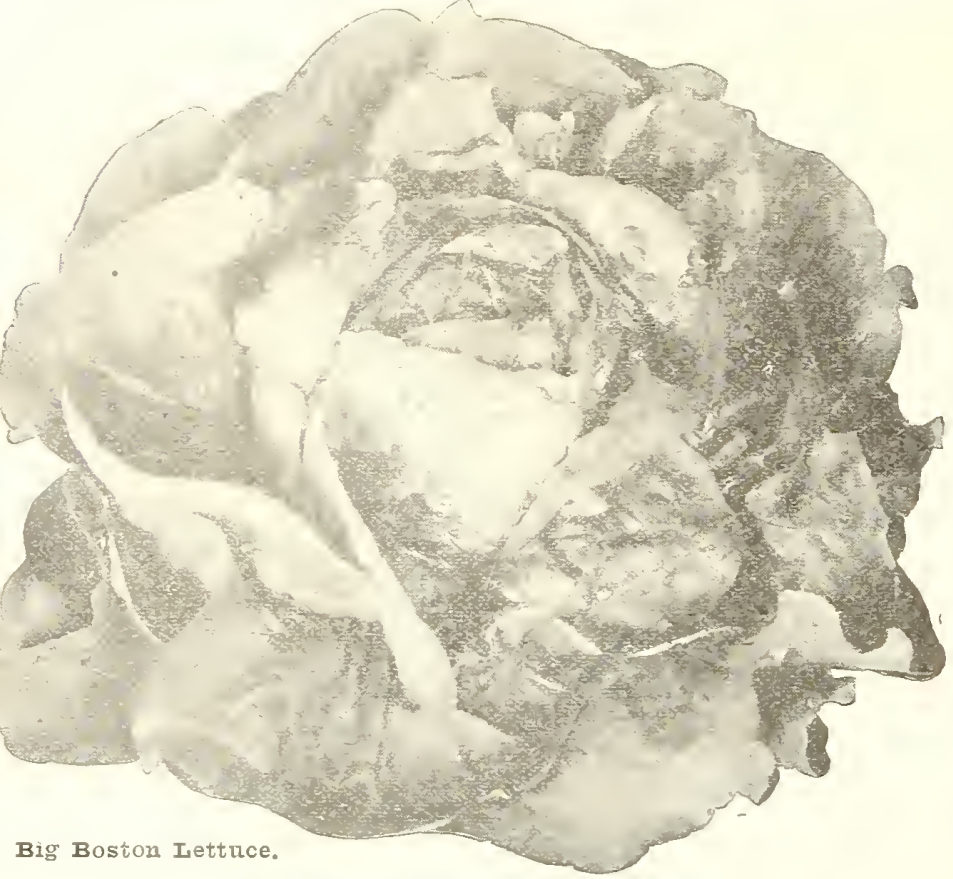

58. Big Boston (Special Stock). Big, compact, tender a $n$ d cris p creams-white heads. Whether grown in the open ground for summer and fall use, or in frames for spring. it invariably gives both grower and user the utmost satisfaction. producing during all seasons, under ordinary farorable conditions. splendid. large, bnttery-rellow heads, packed with thoronghly blanched leares, crisp. tender and sweet. Although "Bic Boston is one of the best large-heading mid-summer Lettuces, it is also peculiarly adapted for late fall culture. Pkt. 5 and 10 cts.; 0z. 15 cts.; I/4 lb. 45 cts.; lb. \$1.50.

146. Golden Queen. One of the best first extra early head Lettnce for eitlier open ground or frame culture, and a good forcer: medium size. solid, solden rellow heads, crisp and tender. Pkt. 5 and $10 \mathrm{cts.;} 0$ z. $15 \mathrm{cts}$; 1/4 lb. $45 \mathrm{cts}$.; Ib. $\$ 1.50$.

219. Earliest Wayahead. Shows a remarkable combination of earliness, firm heading character, handsome appearance and fine quality. Both in cold frames early in the spling and in the open ground-in spring, summer and early fall months - it has proved to be not only the vers earliest and surest heading of all early lettuces erer grown, but also of the rerr timest quality at all seasons. Nayahead is not only earlier than "MIaT Ising" and other choice extra early rarieties, but the heads are larger and more tightls folded. Outer leares are light green. inner leares nicely blanched to a ricl butterp-rellow tint: stands a long time before running to seerl. Pkt. 5 and $10 \mathrm{cts}$.; 0 z. $15 \mathrm{cts}$; $1 / 4 \mathrm{lb} .45$ cts.; lb. $\$ 1.50$.

198. Bolgiano's Golden Heart. There has alrays been a demand for a Big Boston Lettuce without the brown tinge. This Lettuce is black seeded Big Boston with less brown tinge. It will stand longer without going to seed and has a fine large heart, lisht color, and is crisp and tender. Pkt. 5 and $10 \mathrm{cts}$; $\quad 0 z .15 \mathrm{cts}$; $1 / 4$ lb. $45 \mathrm{cts}$; $1 \mathrm{~b} . \$ 1.50$, by mail postpaid.

Dutch Speckled Butter. Produces firm, small heads of excellent quality. Pkt. 5 and $10 \mathrm{cts.}$; 0 z. $15 \mathrm{cts} . ; 1 / 4 \mathbf{l b}$. 35 cts.; 1b. $\$ 1.00$.

Boston Market, or White-Seeded Tennis Ball. While of little or no ralue for outdoor planting, it is a splendid sort for gerring under glass. Small hard heads. Pkt. 5 and 10 cts.; 0z. 15 cts.; $1 / 4$ lb. 35 cts.; lb. $\$ 1.25$.

\section{LETTUCE-Early Varieties}

\author{
One Ounce Will Sow 200 Feet of Drill.
}

Lettuce in certain localities mas be produced in a satisfactory way "the sear round." As all know, lettuce makes one of our most appetizing and delicious salads. There are many rarieties of lettnce, and in order to assist the planter we have carefully classified them, thus making it an easy matter to select the kinds desired.

CULTURE. Sow the seed in hotbeds in February or March, transplant into a sheltering border with a southern exposure. For successive crops sowing may be made in the open ground as early as the spring opens and continuing until July. Always thin out well, or the plants will not be strong. When wanted as a cut salad, sow seed thickly in rows or broadcast.

98. Early May King. I'lants are of quick growth, practically all head and extremely handsome. From early' spring plantings in the open ground they grow quickly to a diameter of 6 to 7 inches, with the broad. light-green outer leares folding closely abont the round solid head: in cool weather the edges of these outer leares are lightly tinged with brown. The inner leares (practically the entire head) are blanched into a rich golden sellow and have a specially fine, rich, bntters flaror. The ronnd solid heals are so firmly folded that ther can be shipped to distant markets and arrire in good condition. We recommend repeated plantings of this fine early variety ir the spring. and again dning Angust and September for fall nse. Pkt. 5 and $10 \mathrm{cts.;} 0 \mathrm{z} .15 \mathrm{cts}$.; 1/4 lb. $45 \mathrm{cts}$.; lb. $\$ 1.50$.

Long Lost Lettuce. Produces large solid compact head. It is a sure header and is rery hards. Will winter eren better than the Big Boston, nerer spots or shows brown in any part of the head. Sweet, crisp and tender. The leading market gardeners say the Long Lost is a profitable Lettuce. Pkt. $10 \mathrm{cts}$; oz. $45 \mathrm{cts} ; \quad 1 / 4$ lb. $\$ 1.35 ; \quad$ lb. $\$ 5.00$.

Millionaire Lettuce. This is a raluable lettuce for the gardeners; will stand much damp cold weather. Quick grower, prodncing large ronnd compact heads, crisp, tender, and has a delicious rich buttery flaror. Pkt. 5 and $10 \mathrm{cts}$.; oz. 25 cts.; $1 / 4$ lb. 60 cts.; lb. $\$ 2.00$.

209. Early Prize-Head. A crisp head sort. Produces a large head of curly leares with edges hearily shaded with brown. Ters popnlar for summer use. Pkt. 5 and 10 cts.; oz. $20 \mathrm{cts} . ; \quad \mathrm{y} / 4$ lb. $60 \mathrm{cts}$.; lb. $\$ 2.00$.

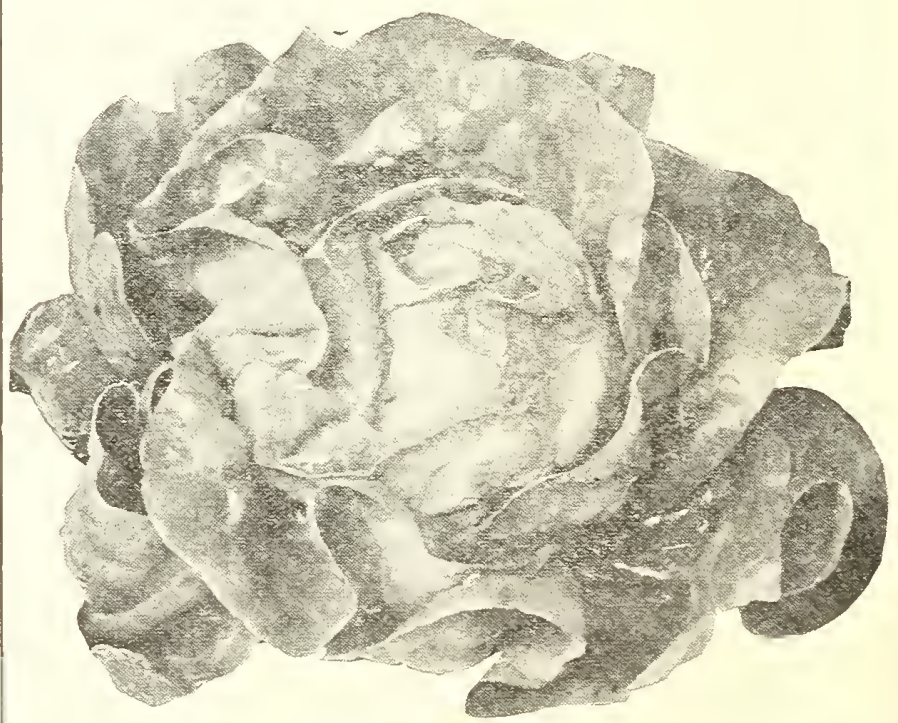

Iong Iost Iettuce. 


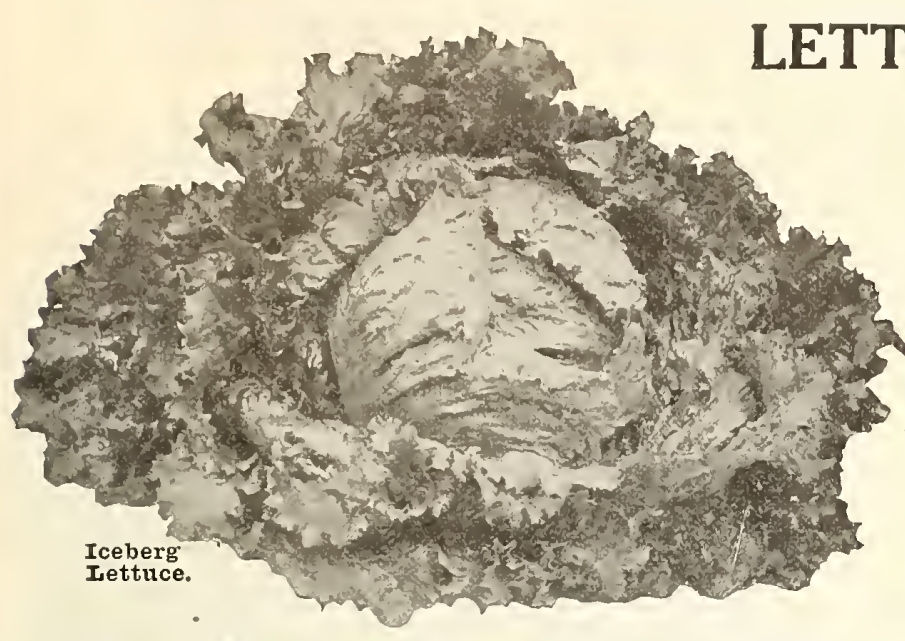

Bolgiano's Masterpiece Lettuce. This wonderful letand tested by thousands of gardeners and lettuce growers, pronouncing the Masterpiece to be the best late spring, summer and early fall lettuce they had ever grown. Sweet, tender and crisp. No bitterness, never spots or turns dark in any part. Just one big head of good solid eating lettuce. Pkt. 5 and 10 cts.; 0z. 45 cts.; $1 / 4$ lb. $\$ 1.35 ; \quad l b . \$ 5.00$.

Brittle Ice. Large, brittle, mild flavored, crisp heading variety. It makes heads 6 to $S$ inches in diameter. Pkt. 5 and 10 cts.; oz. 15 cts.; $1 / 4$ lb. 45 cts.; lb. $\$ 1.50$.
225. New York, or Wonderful. The plints are extra large and produce heads of immense size with the leaves closely folded; inner portion blanches easily, and leaves are always crisp and tender. Pkt. 5 and $10 \mathrm{cts}$; 0 z. $20 \mathrm{cts}$; $1 / 4$ lb. 65 cts.; lb. $\$ 2.00$.

Los Angeles. For many years the Wastern gardeners were confident the Los Angeles lettuce was nothing more than the Iceburg, but they conld never grow the same large solid head today. Most of the lettuce growers linow the value of the Los Angeles. Heads are large, crisp and tender. Pkt. 5 and 10 cts.; oz. 25 cts.; $1 / 4$ lb. 75 cts.; lb. $\$ 2.50$.

Hanson Improved. Is uniformly sure heading; grows to a large size, and the heads blanch easily and are always solid; leaves crisp, mild and tender. One of the best to grow for the summer markets. Pkt. 5 and $10 \mathrm{cts}$; 0 . $15 \mathrm{cts}$.; I/4 lb. 35 cts.; lb. $\$ 1.25$.

C54. Bolgiano's New Wonder. 'Whis new lettuce has solid round beads between 6 and 7 inches in diameter. It is hardy and very early or quick in maturing. The onter leaves are tinged with brown, but not to the extent that Big Boston is. Pkt. 5 and 10 cts.; oz. $25 \mathrm{cts} . ; \quad 1 / 4 \quad 1 b .75 \mathrm{cts}$.; lb. $\$ 2.50$.

191. Iceberg. This is adapted for sowing for either spring or summer use, and no matter the season the leaves are always tender. The Iceberg lettuce has become most popular in tamily gardens. Pkt. 5 and $10 \mathrm{cts}$; 0 z. $15 \mathrm{cts}$.; I/4 Ib. 45 cts.; lb. $\$ 1.50$.

\section{Cabbage, or Butter Head Varieties}

60. Bolgiano's Black Seed Summer. A perfect heading outdoor lettuce, especially during our dry, hot summer, because it is long standing and always tender and pleasant to the taste. It does equally well for forcing under glass in hot beds, cold frames, greenhouses and for outdoor cultivation. Pkt. 5 and 10 cts.; oz. 15 cts.; $1 / 4$ lb. 35 cts.; lb. $\$ 1.25$.

Farmer's Pride. We recommend this Lettuce, feeling that it will give the utmost satisfaction. It forms a large, solid head, slow to seed and early in forming. Its large golden heart with crumpled leaves of bright green makes it pleasing to the eye. Pkt. 5 and $10 \mathrm{cts}$.; oz. $15 \mathrm{cts}$.; 1/4 lb. 35 cts.; lb. \$1.25.

195. Improved Salamander. Especially desirable for late spring sowing. Medium sized, tender heads. Pkt. 5 and $10 \mathrm{cts}$; $0 z .15$ cts.; $1 / 4$ lb. 30 cts.; lb. $\$ 1.00$.

C39. Big Head. Produces exceedingly large heads of the finest quality for summer use. Pkt. 5 and 10 cts.; oz. 15 cts.; 1/4 lb. 35 cts.; lb. \$1.25.

A98. Summer King. It produces immense heads, often 15 and 16 inches across, and heavy in weight. The interior is beautifully blanched, creamy-white, crisp, tender, and delicious, being absolutely free from any trace of bitterness. It is a very large, robust growing variety, rooting deeply, resisting hot dry weather, very slow to seed, and a sure header under trying conditions. Pkt. 5 and $10 \mathrm{cts}$; oz. 15 cts.; $1 / 4$ lb. 30 cts.; lb. $\$ 1.00$.

102. Bolgiano's White Loaf. Gilt edge stock for careful growers. The most experienced truckers pronounce our White Loaf Lettuce the best they ever grew. Lettuce in frames and outdoor is a most important item with our large truckers. 'To suit their purpose a Lettuce must form a reliable head, be crisp and with pleasant flavor. These qualities they find in our White Loaf, which is used in large quantities for fall and spring sowing, and makes a paying crop. Pkt. 5 and 10 cts.; oz. 15 cts.; $1 / 4$ lb. 30 cts.;
11. Mammoth Black Seed Butter. In a trial of several hundrea Lettuces we were impressed with this kind for summer use. It makes a large, light green head; the leaves are slightly crumpled like our White Leaf. It withstands the summer heat. Pkt. 5 and $10 \mathrm{cts}$; 0z. $15 \mathrm{cts}$; $1 / 4 \mathrm{lb}$. 30 cts.; lb. $\$ 1.00$.

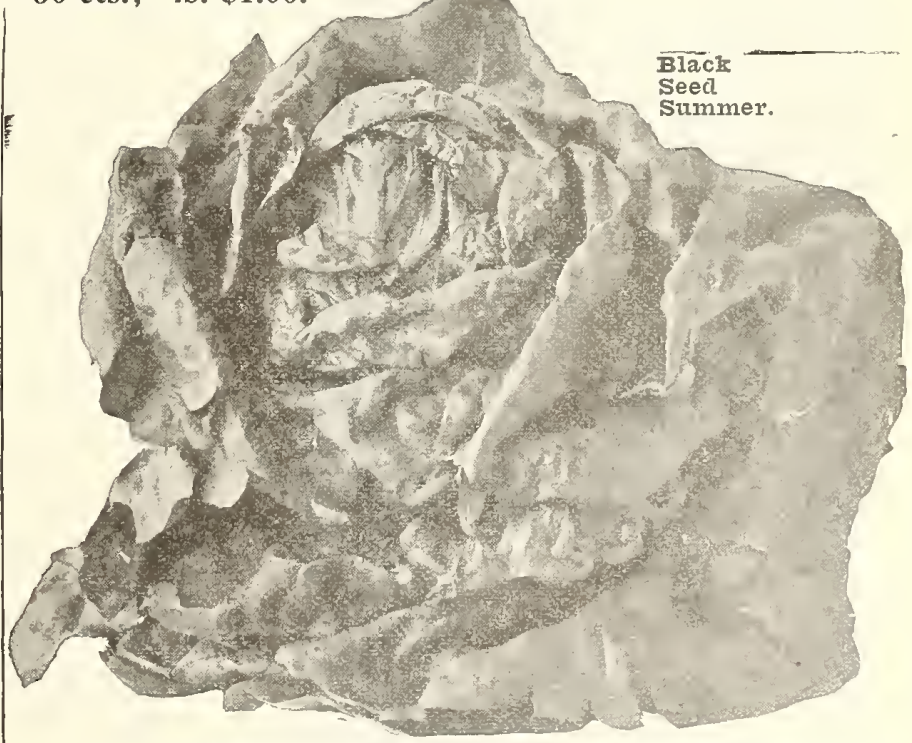

C4. California Cream Butter. A fine variety for growing in the South for shipping North during the winter. The beautiful large heads blanch to an attractive white color; the outer foliage is dark green marked with small brown spots. Pkt. 5 and $10 \mathrm{cts}$; 0 z. $15 \mathrm{cts}$; $1 / 4 \quad \mathrm{lb} .30 \mathrm{cts}$; lb. $\$ 1.00$.

176. Deacon. One of the best to withstand hot weather. Produces fine large heads of delicious flavor. Pkt. 5 and 10 cts.; oz. 15 cts.; 1/4 lb. 35 cts.; lb. $\$ 1.25$. 


\section{LETTUCE-Cabbage Head Varieties (Continued)}

C30. Bolgiano's White Seed Summer. Splendid hard herding Lettuce that will stand the heat and make at the same time a large head with a golden heart, free from a bitter taste. Pkt. 5 and $10 \mathrm{cts.;}$ oz. $15 \mathrm{cts}$.; 1/4 lb. $30 \mathrm{cts}$; lb. $\$ 1.00$.

132. Hubivard Market. One of the rers best Lettuce for planting in the fall to stand over winter. either in cold frames or outside. Mrakes a large, solif head, with outside leares a delicate green, and inside head a fine light color of superior qualits. Pkt, 5 and $10 \mathrm{cts}$.; oz. $15 \mathrm{cts}$; $1 / 4 \mathrm{lb}$. 30 cts.; lb. \$1.00.

\section{Loosehead, Cutting Varieties}

227. Grand Rapids. This does not form heads. but makes large compact bunches of light leares with fringed edges. Its delicious quality and handsome appenrance make it most popular in winter markets of many Western cities. It is useful also for outdoor planting during spring and fall, Our stock is the best it is possible to produce. Pkt. 5 and $10 \mathrm{cts}$; 0z. $15 \mathrm{cts}$; I/4 lb. $45 \mathrm{cts}$.; Ib. $\$ 1.50$.

C38. Early Curled Simpson, or Silesia. A standard old farorite. Produces early custers of crisp golden leares of fine quality. Pkt. 5 and $10 \mathrm{cts}$; 0 oz, $15 \mathrm{cts}$; $1 / 4 \mathrm{lb}$. 30 cts.; lb. $\$ 1.00$.

174. Black-Seeded Simpson. Recommended both for home and market gardens. The golden sellow curly leares are crisp, tender and mild. Pkt, 5 and $\mathbf{1 0}$ cts.; 0 z. 15 cts.; I/4 lb. $30 \mathrm{cts}$; 1b. $\$ 1.00$.

\section{LETTUCE, COS, or CELERY}

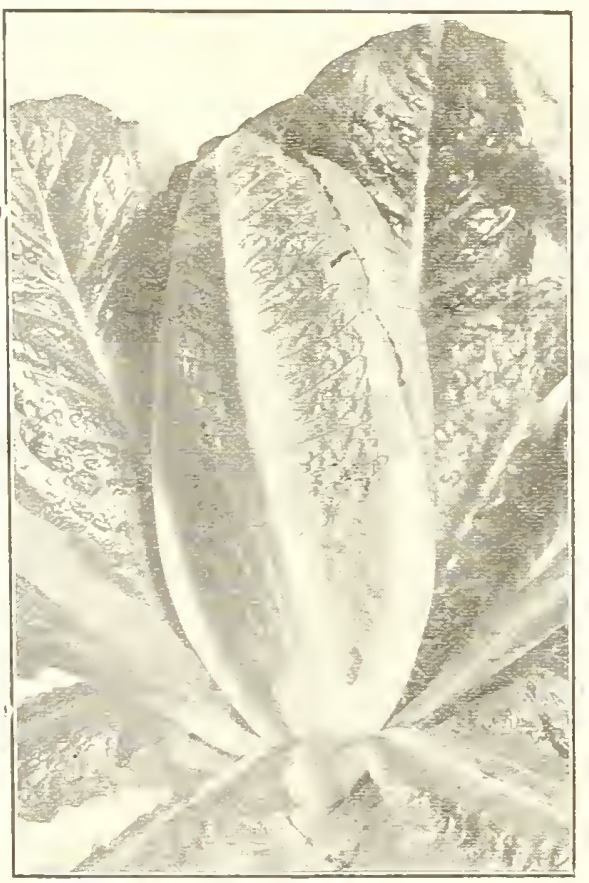

Cos Iettuce.

\section{(ROMAINE)}

Cos Lettuce, or Romaine, as it is frequently called on some markets, is not so generally grown as it should be in the United States.

In the $\mathrm{S}$ o u t $\mathrm{h}$, C os Lettuce succeeds best during the early spring months. or late in the fall.

\section{Eclipse,} or Express. Very earls. The plants are of stiff, erect, compact growth, and attain beight of about 6 inches. The leares fold so neatly and tightly as to make tying up u n n e cessary. The head blanches to an almost pure wh ite, and the leares are almars mild in flaror. Pkt. 5 and 10 cts.; oz. 15 cts.; $x / 4$ Ib. 35 cts.; lb. \$1.25.

C23. Trianon (Paris Self-Folding White). Of rather tall growth and produces large conical shape heads. The long leares blanch an almost snowr white, and are usually eaten like celerr. hence it is sometimes called Celery LetPkt. 5 cts.; oz. 15 cts.; I/4 rb. 35 cts.; 1b. \$1.25.

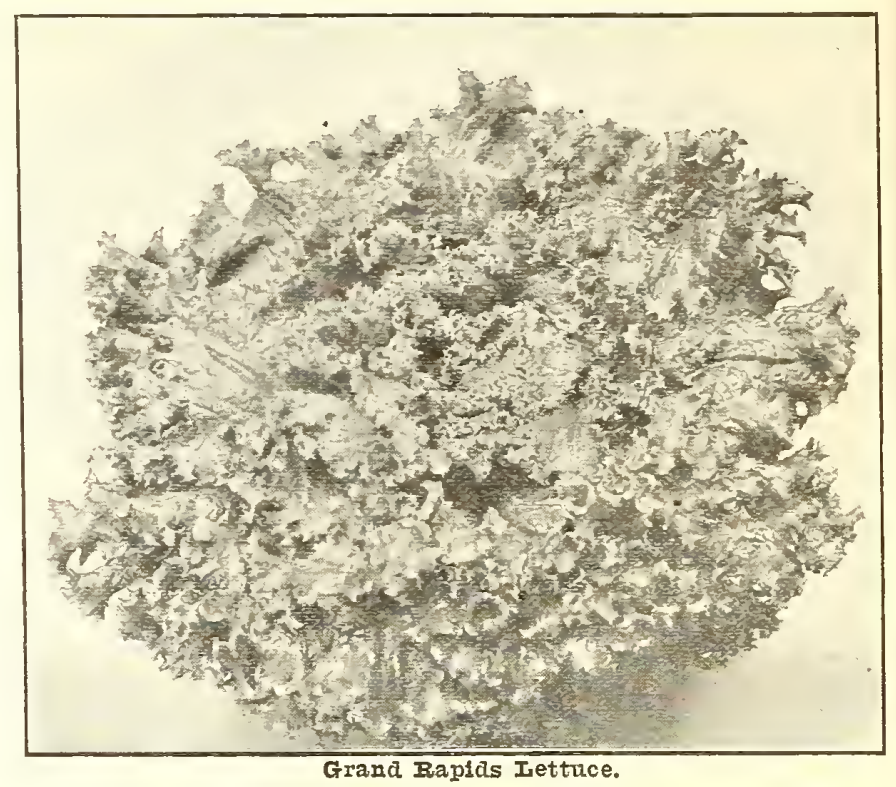

1. Bolgiano's Oak Leaf. 'This is rerr desirable for summer use, withstanding extreme heat much better than many other sorts. Pkt. 5 and $10 \mathrm{cts}$; $0 z .15$ cts.; $1 / 4 \mathrm{lb} .30 \mathrm{cts}$; 1b. $\$ 1.00$.

\section{LEEK}

One ounce to sow a Drill of 100 feet CUITURE. The Leek is very hardy, of easy culture, and succeeds best in a light soil. Sow early in April in drills 1 foot apart and 1 inch deep. Tinen theot apart and 1 inch deep. transplant in a deep, rich soil in rows 12 ins, apart and 6 ins. in the rows, as deep as possible, so that the nech may be covered and blanched; draw the earth to them as they grow. The seed may also be sown in August or September, and the young plants transplanted in the spring.

50. Extra Large Leek. It is the best. This mammoth leek is not to be compared with the old kinds. It grows much larger and is rers handsome. Pkt. $\mathbf{5}$ and 10 cts.; oz. 20 cts.; 1/4 lb. $60 \mathrm{cts}$.; lb. $\$ 2.00$.

\section{Broad London, or Large} American Flag. A rery strong growing rariety with large thick stems of fine sweet flaror. One of the most popular rarieties with large planters. Pkt. 5 and $\mathbf{1 0}$ cts.; 0z. 25 cts.; I/4 lb. 70 cts.; lb. $\$ 2.25$.

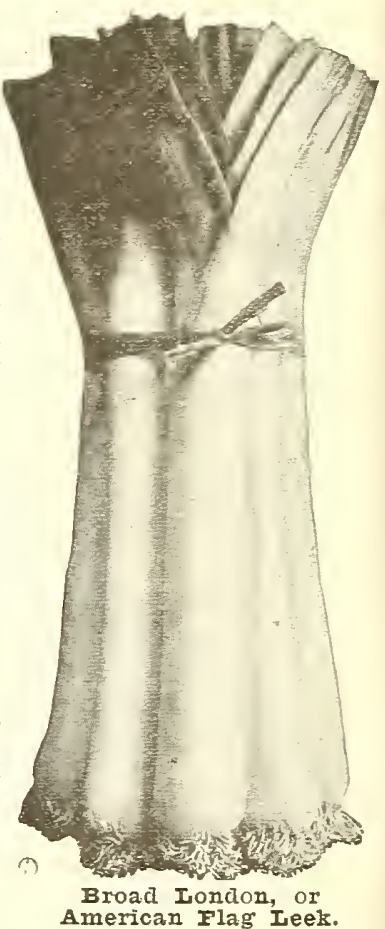

\section{SAVE MONEY BY ORDERING ONE OF THE COMPLETE}

VEGETABLE GARDEN COLLECTIONS

See page 41. 


\section{MUSKMELON, or CANTALOUPE}

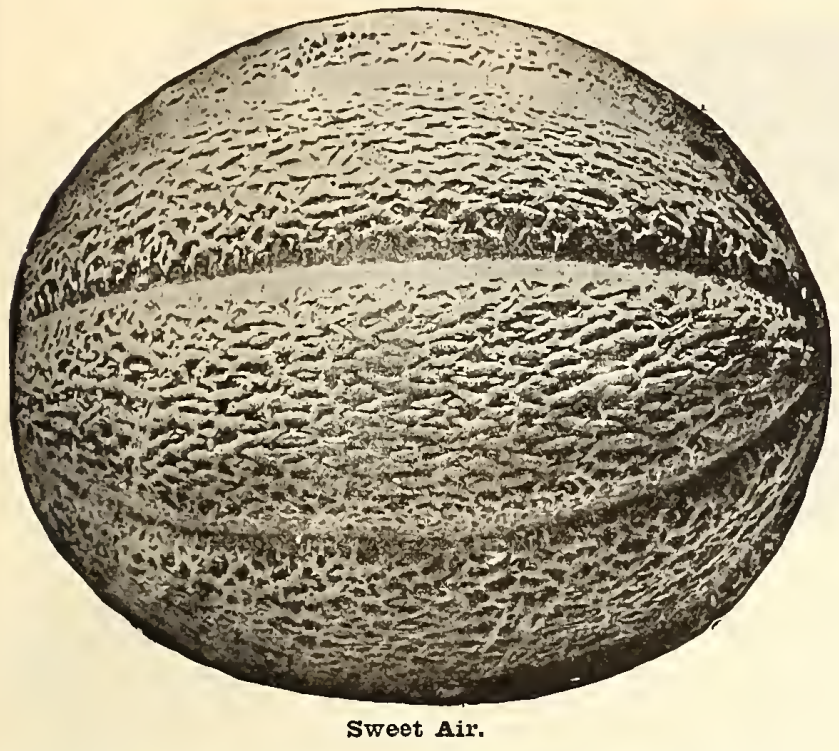

CUITURE. Melons thrive best in a rich, light soil. Plant early in May, when the ground has become warm and dry, in hills six feet apart each way for muskmelons, eight feet for watermelons. Previous to sowing the seed, mix a few shovelfuls of well-rotted manure in each hill, and plant in each 12 to 15 seed; after all danger of the bugs is over, thin out to three plants per hill. When about one foot long, pinch off the tips to make them branch, as it strengthens the growth of the vines and makes the fruit mature earlier. Give plenty of water and feed liquid manure occasionally. A few hills for early use may be had by sowing on pieces of sod in a hotbed, and when warm enough transplant to open ground.

\section{Green Flesh Varieties}

41. Sweet Air. A splendid Melon for all purposes. Be 4. Pkt. 5 and 10 cts.; oz. 25 cts.; $1 / 4$ lb. 75 cts.; lb. $\$ 1.50$.

Jr. Rocky Ford. Two weeks earlier, a little larger and twice as productive as the Rocky Ford, one of the best rust and blight resisters. Vigorous grower, vines keep green and produce big crops of fine market melons. Its netting is close and deep, sweet flavor, thick green flesh with small seed cavities, make a very fine shipping melon. Pkt. 5 and 10 cts.; oz. 25 cts.; 1/4 lb. 60 cts.; lb. $\$ 2.50$.

C32. Knight. It is not liable to blight, considerably earlier in maturing and nearly, if not quite, as large as the Sweet Air. The flavor is equal to the best on the market. The melons are firmly netted, uniform in size, and the thick green flesh is most delicious in flavor. Pkt. 5 and 10 cts.; oz. 15 cts.; $1 / 4$ lb. 35 cts.; Ib. $\$ 1.25$, by mail postpaid.

A48. Eden Gem. A medium-sized melon, nearly round in shape, very heavily netted and very slightly ribbed. The flesh is extremely thick, the seed cavity very small. It is medium early and very prolific. The vine is vigorous and will resist blight. Pkt. 5 and 10 cts.; oz. 15 cts.; 1/4 lb. 30 cts.; lb. \$1.00.

39. Rocky Ford, or Netted Gem. One of the bestknown cantaloupes in the world. When this melon was first placed on the market it made a name and a place for itself. Its fine flavor, bright green, very deep meaty flesh, make it a popular variety. Pkt. 5 and 10 cts.; oz. 15 cts.; 1/4 lb. 30 cts.; lb. $\$ 1.00$.

48. Pollock's Netted Rock, or Money-Maker. Growers in Rocky Ford have been trying to get a RUST-PROOF and BLIGIIT-PROOF MELON, It is distinct in its markings, being almost entirely covered with netting, slightly larger than the Rocky Ford; very delicious in the spicy sweet cantaloupe flavor. Nearly rust-proof and blight-proof. Pkt. 5 and 10 cts.; oz. 15 cts.; 1/4 lb. 30 cts.; lb. $\$ 1.00$.
81. Bolgiano's Baltimore Nutmeg. Our seed this season has been grown from the old original stock seed. The Baltimore Nutmeg is a large green-flesh variety, swcet as sugar. Pkt. 5 and 10 cts.; oz. 15 cts.; $1 / 4 \mathrm{lb} .35 \mathrm{cts}$; lb. $\$ 1.00$.

Watter's Improved. One of the earliest, it is the most valuable sort to plant where first in the market is of grcat importance. Light green flesh. Sweet and tender. The heavy netting makes it a successful melon for both gardens and shippers. Pkt. 5 and $10 \mathrm{cts}$; oz. $15 \mathrm{cts}$; $1 / 4 \mathrm{lb} .35$ cts.; Ib. \$1.25.

C27. Jenny Lind. Small-fruited green-fleshed variety of finest flavor. Early and productive. Pkt. $\overline{5}$ and $10 \mathrm{cts}$.; oz. 15 cts.; 1/4 lb. 35 cts.; lb. $\$ 1.00$.

AC32. Maryland The vines are of a strong, healthy growth, branch freely, setting a large number of fruits close to the hill. Regular in size and form, and very closely netted. Flesh bright green, luscious in flavor. Pkt. 5 and $\mathbf{1 0}$ cts.; oz. 15 cts.; 1/4 lb. 30 cts.; lb. $\$ 1.00$.

224. Extra Early Hackensack. Thick green flesh, is of fine flavor. Pkt. 5 and $10 \mathrm{cts}$; oz. $15 \mathrm{cts}$; 1/4 lb. $30 \mathrm{cts}$; lb. $\$ 1.00$.

C49. Honey Dew Melon. Has a peculiar sweet pleaswish his capacity was unlimited. It must be dead ripe before being prepared for the table. Pkt. 5 and 10 cts.; oz. 15 cts.; 1/4 lb. 45 cts.; ib. $\$ 1.50$.

\section{Salmon Flesh Varieties}

Bolgiano's Unsurpassed. Specialty, see page 4. Enorsolid netted. Orange colored mous producer, best shipper, sweet flavor. Fairly melts in your mouth. Pkt. 5 and 10 cts.; oz. 35 cts.; $1 / 4$ lb. 85 cts.; lb. $\$ 3.50$.

180. Golden Sugar. It is a pleasure for us to offer again this salmon flesh melon which has given such universal satisfaction to those who have grown it. This sweet, deep-fleshed melon has a flavor that invites all who taste, while its regularity of size and tough rind recommend it to shippers. Pkt. 5 and $10 \mathrm{cts.;}$ oz. $15 \mathrm{cts}$; 1/4 lb. $45 \mathrm{cts}$; Ib. $\$ 1.50$.

99. Burrell Gem. Another desirable salmon-fleshed variety. Melons about same size as preceding, but they are more oval in shape, and are well ribbed. The flesh is thick and of delicious flavor. Pkt. 5 and 10 cts.; oz. 15 cts.; 1/4 lb. 30 cts.; lb. $\$ 1.00$.

77. Paul Rose. Slightly oval in shape with deep orange flesh. Pkt. 5 and 10 cts.; oz. 15 cts.; 1/4 lb. 30 cts.; 1b. $\$ 1$.

C8. Emerald Gem. Tho melons weigh about $11 \frac{1}{2}$ lbs. and are somewhat flat at stem and blossom ends. The skin is smooth and free from netting, and is ribbed. Seed cavity small and the salmon flesh is thick and of finest flavor. Highly recommended for nearby markets and home gardens. Pkt. 5 and $10 \mathrm{cts}$; oz. $15 \mathrm{cts}$; $1 / 4 \mathrm{lb} .30 \mathrm{cts}$; 1 lb. $\$ 1.00$.

54. “Tip Top." Sweet, juicy, finest flavored, firm (but not hard) 1leshed. Pkt. 5 and $10 \mathrm{cts}$; oz. $15 \mathrm{cts}$; 1/4 lb. 30 cts.; lb. $\$ 1.00$.

Banana Cantaloupe. Deep golden flesh, exquisite flavor. Pkt. 5 and 10 cts.; oz. 15 cts.; I/4 lb. 45 cts.; lb. $\$ 1.50$.

Extra Early Osage Gem. Delicious sweet flavor; tender; extremely prolific. Pkt. 5 and 10 cts.; oz. 15 cts.; I/4 Ib. 30 cts.; Ib. $\$ 1.00$.

10-25. Cantaloupe. A re-selection of the Pollock Sal= mon Tint, No. 25 Strain, which in the last few year's has become very popular among market gardeners. Orange flesh. tender, sweet flavor, without strings or toughness; excellent shipper, good seller. Pkt. 5 and $10 \mathrm{cts.;} \mathrm{oz.} 20 \mathrm{cts}$; 1/4 lb. lb. 60 cts.; lb. $\$ 2.00$. 


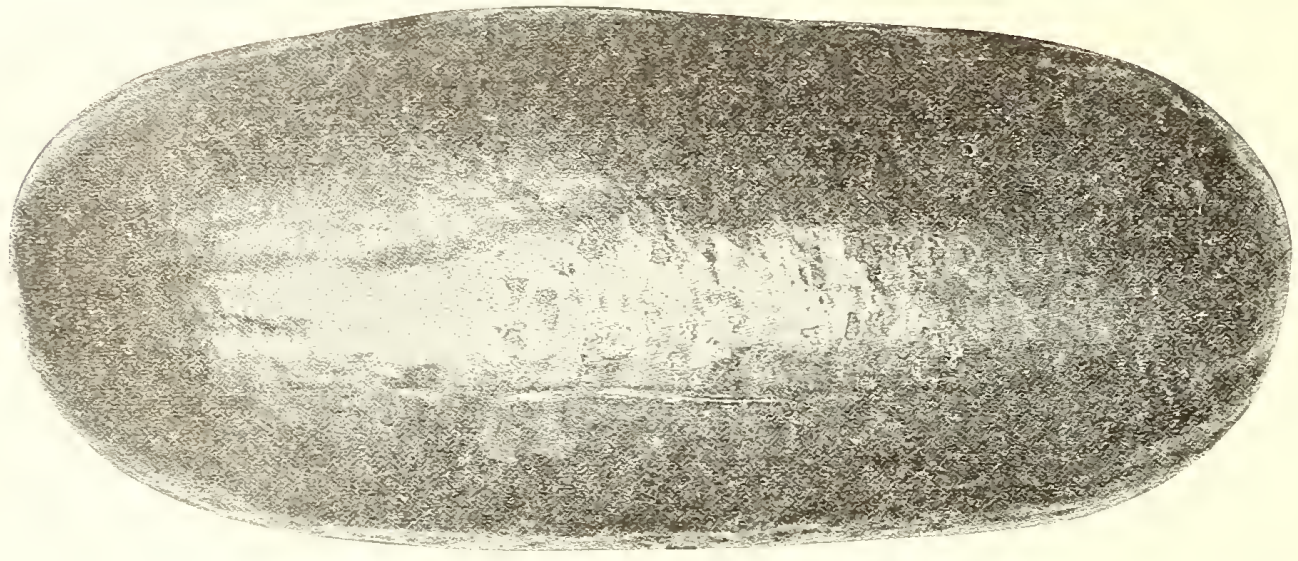

In the planning of sour garden be snre and include a few hills of Watermelon. These do not require any great effort to produce a satisfactors crop. See cultural directions on page 25 for Cantalonpes.

There is nothing more deli. cious on a red-hot summer das than a well-chilled Watermelon.

General Pershing Watermelon. The finest melon ever

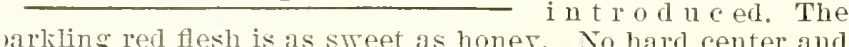
stringless. Flesh firm and compact. Mind tough: will stand shipping from Florida to Canada in perfect condition. Vigorous grotrer. Tines keep sreen and produce enormous crop of first-grade melons meighing 35 to 51 pounds each. Pkt. 5 and 10 cts.; oz. 20 cts.; I/4 lb. 60 cts.; lb. \$2.00.

64. Tom Watson. This old favorite is an extra long melon of attractive appearance, uniform in shape and quality; the lnscious crimson flesh is "as street as honer," melting and of superb flaror. The arerage melon will weigh 35 to 40 pounds and measure 25 inches long and about 12 inches in diameter. As a shipping melon, it has held first place and is also quite popular for home use. Pkt. 5 cts.; oz. $10 \mathrm{cts.;}$ I/4 lb. $20 \mathrm{cts}$; Ib. $60 \mathrm{cts}$.

181. Irish Grey. The rare combination of tempting sweet flaror and a tough rind make this melon one of such superior merit that it mell deserres the popularity that it has been receiring among growers for shipping and home use. One feels a little disappointed at the first sight of the light green rind, but the riew and taste of the delicious interior makes fast friends. Pkt. 5 and 10 cts.; oz. 15 cts.; I/4 lb. $25 \mathrm{cts}$; 1b. $75 \mathrm{cts}$.

Bolgiano's Indion Chief. Is entirely distinct from all other rarieties. It is a large, oblong, dark green melon; the rind is thin, but tough, which makes it a first-class shipping melon. Flesh bright red; delicious street flaror: prodnces big crops, all select size. Our demand for seed each rear increases. Pkt. 5 and $10 \mathrm{c} ; 0 z .15 \mathrm{c} ; \mathrm{r} / 4$ lb. 30c; lb. $\$ 1.00$.

144. Improved Florida Favorite (White Seeded). Early. Fine quality; medium size; flesh deep red. Pkt. 5 cts.; 0z. 10 cts.; I/4 lb. 20 cts.; 1b. 50 cts.

C48. Kileckley Sweet, or Monte Cristo. A fine melon for home groming and table use. Vines are strong, rigorous and the fruits grow to large size, 18 to 20 inches long and 12 inches in diameter. Skin is a rich. dark green; flesh bright scarlet, ripening close to the rind. Which is but half an inch thick. so that shipping it long distances is not practicable. Crisp, sugary, melting and entirely free from stringiness. Pkt. 5 cts.; oz. $10 \mathrm{cts}$; 1/4 lb. $20 \mathrm{cts}$; lb. $60 \mathrm{cts}$.

150. Triumph. It is a cross between Duke Jones and Kolb's Gem. Has the handsome appearance and dark green color of the former and the shipping qnalities of the Gem; medium season. Fers prolific, deliciously sweet and of enormous size. Pkt. 5 cts.; oz. 10 cts.; I/4 lb. 20 cts.; lb. 50 c.

179. Halbert Honey. A rers street, long, dark green rarietr. Fruits a rerage 18 to 20 inches long, has a thin rind and deep red meat of delightfully delicious flaror: pulp entirely free from stringiness; seed white. Pkt. 5 cts.; oz. 10 cts.; I/4 lb. 25 cts.; lb. 60 cts.
Excell-the New Watermelon. A long green melon, Handsome in appearance and far surpasses the Tom Tratson both as a shipper and for the table. Pkt. 5 and $10 \mathrm{cts}$.; 0z. 15 cts.; 1/4 lb. 30 cts.; lb. $\$ 1.00$.

63. Round Light Icing. Round : pink flesh of fine qualits. Pkt. 5 cts.; oz. 10 cts; 1/4 lb. 20 cts.; lb. 50 cts.

70. Jordan's Gray Monarch. Large melons ; crimson flesh; late. Pkt. 5 cts.; oz. 10 cts.; $1 / 4$ lb. 25 c; lb. 60 c.

221. Cuban Queen. Solid and hears, finest quality. Pkt. $5 \mathrm{cts}$.; oz. $10 \mathrm{cts}$; 1/4 lb. $20 \mathrm{cts}$.; lb. $50 \mathrm{cts}$.

197. Ice Cream, or Peerless. Terr early; r e d flesh. Pki. 5 cts.; oz. 10 cts.; $1 / 4$ lb. 20 cts.; lb. 40 cts.

88. Kolb Gem. Large; good shipper; bright red flesh: intermediate. Pkt. 5 cts; oz. 10 cts.; I/4 lb. 20c; lb. $50 c$.

C14. Georgia Rattlesnake. Oblong, dark and striped; bright red flesh; late. Pkt. 5 cts.; oz. 10 cts.; $1 / 4$ Ib. 20 cts.; lb. 50 cts.

120. Sweetheart. Tery large: fine quality. Pkt. 5 cts.; oz. 10 cts.; $\quad \mathrm{T} / 4$ lb. $20 \mathrm{cts}$; 1b. $50 \mathrm{cts}$.

220. Preserving Citron. Medinm size, uniformly round, used only for preserves or pickles. Color dark green. distinctls striped and marbled with light gleen. Flesh white and solid. but not at all suitable for eating raw. Seed red. Pkt. 5 and $10 \mathrm{cts}$; 0z. $15 \mathrm{cts}$; $1 / 4 \mathrm{lb} .25 \mathrm{cts}$.; lb. $75 \mathrm{cts}$.

\section{MUSHROOMI SPAWN}

II : shrooms may be grown in cellars, under benches or greenhouses or in sheds, wherever the temperature of 50 deorees can be kept up through the winter. The beds should be made from November to February, according to the time the IIushrooms are wanted, and it requires about two months for them to begin bearing. Secure fresh horse manure, free from straw and litter, and mix an cqual bulk of loam from an old pasture with it. Keep this under cover, taking care to turn it every day to prerent heating, until the pile is large enough to make a bed the required size. Three or four feet wide, 8 inches deep and any required size. Three or four feet wide, $\delta$ inches deep and any may be raried. Prepare the mixture of loam and manure, makof the spade. Leave this to heat through for a few days, and as soon as the heat subsides to 90 degrees make holes in the bed about a foot apart eacin way, into which put pieces of the spawn 2 or 3 inches in diameter: fill up the holes with the compost, and at the expiration of a week or ten days the spawn "will have thoroughly diffused itself through the bed. Spread a layer of fresh soll over the heap to the depth of 2 inches and cover with fresh soll over the heap to the depth of 2 inches and cover with see that it does not get dry. Take special care, however, when water is given that it be at a temperature of about 100 degrees.

American Spawn. In bricks. Per brick, 25 cts.; 10 bricks, $\$ 2.25$; per 100 bricks, $\$ 20.00$.

If requested, with each one dollar order for Mushroom bricks, we will send a book on Culture. Books alone, $10 \mathrm{c}$. 
One Ounce Will Sow 100 Eeet of Drill.

\section{ONION}

Six Pounds

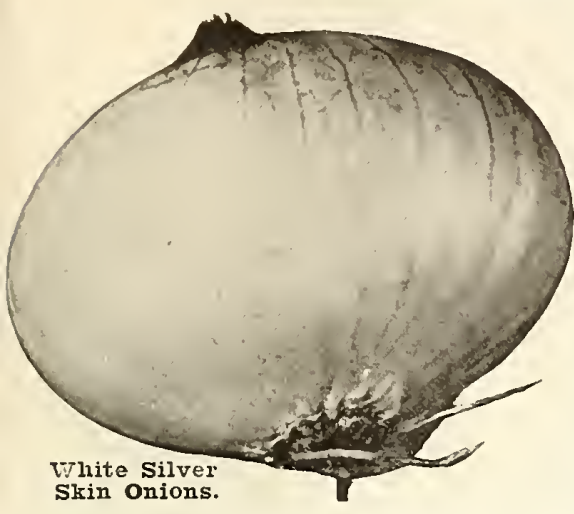

CUITURE. For sets sow the seed carly as possible in the spring. very thiclily in drills. As soon as the tops die off in summer remove then to a dry, airy place, and early in the following spring replant by placing the sels in shallow drills. 12 inches apart, and about 4 inches apart in the drills. The onions obtancd by that process are of a large size carly in the season. May also be grown to full size during the first season by sowing thinly in drills 1 foot apart and about $1 / 4$ inch deep in March or carly Skin onions. in April, in strong land, well manured, and thinning them out to
3 to 4 inches apart in dills. They delight in a strong, rich, deep, loamy soil, and succeed well if glown successive years on the same ground. By sowing onion seed in frames in February and obtained. For this purpose Prize-Taker succeeds best.

85. White Silver Skin. This famous onion retains its great popularity. Its delicate and mild flavor, its shapely form and size, and its pure white color make it a most desirable variety for the table, for the market and for shipping. Onion sets are extensively grown from this sort, and from these sets full-size onions are grown as early as June and July. The onion sets and large onions are used for fickling purposes because of their clean, silvery white color. Pkt. 5 and 10 cts.; oz. 20 cts.; 1/4 lb. 60 cts.; lb. $\$ 2.00$.

C13. Australian Brown. It is of medium size and of good quality, very early, rather flattened in shape, brown in color, and wonderfully hard and solid. It begins to form a bulb at an early period of its growth, when only a few inches high, and quickly reaches maturity. Its leading and most valuable feature, aside from its appearance and quality, is its long-keeping quality. It will literally keep for a year or more. Pkt. 5 and 10 cts.; oz. 15 cts.; $1 / 4$ lb. 45 cts.; lb. $\$ 1.50$.

\section{Yellow Globe Danvers. A popular variety of} fine flavor and a splendid producer. Pkt. 5 and 10 cts.; 02. 15 cts.; 1/4 lb. 35 cts.; lb. $\$ 1.25$.

C40. Southport Yellow Globe. Some gardeners claim the Eastern-grown seed produces a more solid onion than the western-grown. Pkt. 5 and 10 cts.; oz. 15 cts.; 1/4 lb. 45 cts.; lb. $\$ 1.50$.

36. Danver's Fine Yellow. Color brownish - yellow; bulbs quite round and of good size. This is one of the varieties grown for sets, thousands of bushels of which are annually shipped from this market to different parts of the United States. They are more hardy than the whites, and keep better through the winter. Pkt. 5 and $10 \mathrm{cts}$; oz. 15 cts.; $1 / 4$ lb. 35 cts.; lb. $\$ 1.25$.

C63. Mammoth Prize-Taker. This onion is seen on fruit stands in the fall and is the largest and handsomest. onion in cultivation, and can be grown full size from seed. It keeps well, has white flesh, and mild, delicate flavor. Pkt. 5 and 10 cts.; oz. 15 cts.; $1 / 4$ lb. 45 cts.; lb. $\$ 1.50$.

C45. Large Red Wethersfield. P r o d u c es beautiful thick flat-shaped, rich, purplish-crimson colored solid bulbs. It always commands a good price in the market. It is a good keeper and of excellent quality. Pkt. 5 and 10 cts.; oz. 25 cts.; 1/4 lb. 75 cts.; lb. $\$ 2.75$.

C64. Southport White Globe. of all our American varieties of market onions, this generally commands the highest price. Of true globe form, the onions are 2 to $2 \frac{1 / 2}{2}$ inches in diameter, with a thin, delicate skin of purest paper whiteness. The flesh is crisp, fine grained, snowy white in color and very mild flavor. The bulbs should be stored in a cool, dark loft or shed to dry as soon as they are ripe enough to harvest. Pkt. 5 and $10 \mathrm{cts}$; oz. $20 \mathrm{cts}$; 1/4 lb. 60 cts.; lb. $\$ 2.00$.

A85. White Portugal. Fine color; mild flavor; pure white. Fine for onion sets and pickles; will grow to large size if sown thinly and kept worked. Pkt. 5 and 10 cts.; oz. 20 cts.; $1 / 4$ lb. 60 cts.; lb. $\$ 2.00$.

Yellow Bermuda Onion Teneriffe. It is oval in shape, white, very early, mild llavor, and will produce full grown onions from seed the sime season, in the Southern States. Seed grown in early fall will produce larese onions for the market in early spring. Pkt. 5 and $10 \mathrm{cts}$; oz. 20 cts.; $\bar{i} / 4$ lb. 60 cts.; lb. $\$ 2.50$.

Crystal Wax-Onion Teneriffe. The very best onion produced in Teneriffe. Pure crystal white, extra early, mild flavor and will demand the highest market prices. Pkt. 5 and $10 \mathrm{cts}$; oz, $25 \mathrm{cts}$.; $1 / 4 \mathrm{lb} .85 \mathrm{cts}$; lb. $\$ 3.50$.

Red Bermuda Onion Teneriffe. Shape and size similar to white. differing only in color. A most desirable sort to grow. Pkt. 5 and $10 \mathrm{cts}$; 0 oz. $20 \mathrm{cts}$; $1 / 4 \mathrm{lb} .60 \mathrm{cts}$.; lb. $\$ 2.50$.

\section{ONION SETS}

For years we have made Onion Sets one of our specialties. and this season our stock is larger and finer than ever. We are prepared to offer Onion Sets in any quantity, from one bushel to a carload.

White Silver Skin. Per bushel. . . .\$3.00

Yellow Danvers. Per bushel. $\$ 2.75$

Red: Weathersfield. Per bushel. . . . \$2.75

Prices subject to market changes.

Onion Sets by Mail. We will send by mail postpaid either Yellow or White Onion Sets at $15 \mathrm{cts}$. per $1 / 2 \mathrm{lb}$. (about one pint), or 25 cts. per lb. (about one quart), s a f el $y$ packed.

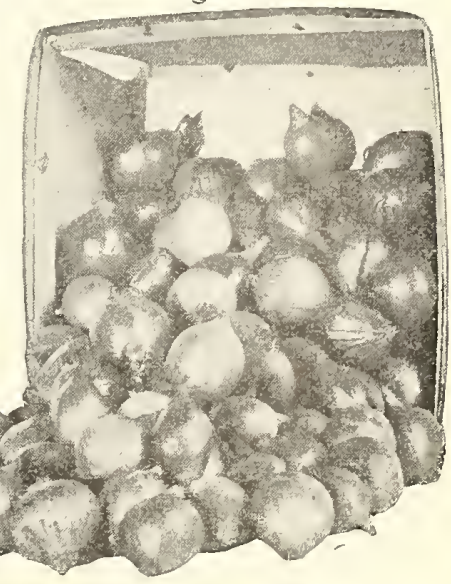

Onion Sets.

\section{MUSTARD}

One Ounce of Seed Will Sow 50 Feet of Drill.

Mustard is one of the best greens, and a supply may easily be obtained throughout the entire season if succession sowings are made Try Mustard cooked like Spinach. It is very easly grown and will thrive in any part of the garden. For late spring use sow in February. March or April; for fall use sow in August and September. Sow the seed in rows 8 to 10 inches apart. One and september. Sow the sect 100 feet of drill; about 5 lbs, is required ounce will sow about 100 feet
for an acre if sown broadcast.

\section{C6. Southern Giant Curled.} that can be desired. Ilant in fall for early spring salad. A popular variety. Pkt. 5 and $10 \mathrm{cts}$; $0 \mathrm{z} .15 \mathrm{cts} . ; \mathrm{r} / 4 \mathrm{lb}$. 20 cts.; lb. $60 \mathrm{cts}$.

C9. Chinese. Differs from the preceding in that the large, broad leaves are smooth and flat. The plants produce a large quantity of leaves which are delicious when cooked and served like Spinach. Pkt. 5 and 10 cts.; oz. 15 cts.; r $/ 4$ lb. 20 cts.; lb. $60 \mathrm{cts}$.

Ostrich Plume Mustard. The plants are of vigorous growth; dark green leaves curve outward like a fine ostrich plume. Fine flower, one of the best for early salad. Pkt. 5 and $10 \mathrm{cts}$.; oz. $15 \mathrm{cts}$; $1 / 4 \mathrm{lb} .25 \mathrm{cts}$.; $1 \mathrm{lb} .75 \mathrm{cts}$. 


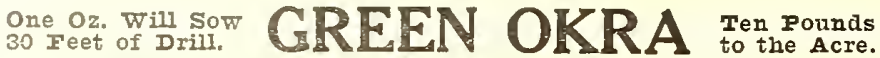

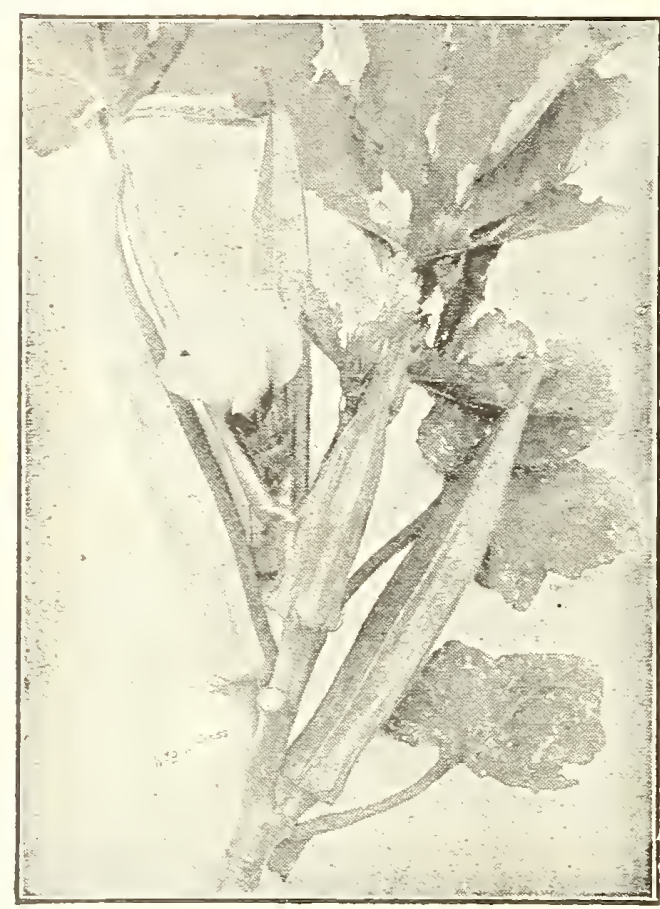

Improved Loug Green Okra.

C U I T U R This vegetable is ext ensively green pods. in soups, stews, etc., to which rich flavor, and a $r$ e considered a $r$ e considered
nutritious. Sow seed thickly in rich ground about the middle of May, or w h e $\mathrm{n}$ ground has become warm, in drills inch deep: thin to $10 \mathrm{ins}$. apart in drills.

\section{Dwarf} Green

Prolific.

The pods impart fine fla ror a n d consistencr to soups and stews, besides being reris palatable when stewed and ser red like a dish of Asparagus. Its which are used pods can be easily dried for winter. So delicious is the flavor that when once used it will be grown every year in Northern as in Southern gardens. Pkt. 5 and 10 cts.; oz. 15 cts.; $1 / 4$ lb. 20 cts.; lb. 50 cts.

C28. Improved Long Green. A rery desirable sort for market gardeners; of medium height: vers handsome: bears long pods, which remain tender a long time and are free from hard ridges. Pkt. 5 and 10 cts.; oz. 15 cts.; T/4 lb. 20 cts.; lb. 50 cts.

White Velvet. A popular new rariety with white pods. Pkt. 5 and $10 \mathrm{cts}$; 0z. $15 \mathrm{cts}$; $1 / 4$ lb. $20 \mathrm{cts}$; lb. $60 \mathrm{cts}$.

Perkin's Mammoth Long-Podded. Pods shoot out from the stalk within three inches of the ground and the whole plant is corered with them to its extreme height. Pods are an intense green color. 9 to 10 inches long, rery slim and do not get hard. Pkt. 5 and 10 cts.; oz. 15 cts.; I/4 lb. 20 cts.; lb. 60 cts.

\section{One Ounce Will Sow D
I00 Feet of Dilli.}

Six Pounds to the Acre.

CULTUİ. Succeds best in a mellow, rich soil. Sow thickly in April in lows $1 \mathrm{ft}$ apart and $1 / 2$ inch deep; thin out the plants to stand 6 ins, apart in the rows. The seed is slow of germination, taking from 3 to 4 weeks to make its appearance, and often failing to come un in dry weather. To assist its coming up raicker soak the seed a few hours in To assist its coming up damp earth and sow when it swells or bursts. For winter use damp earth and sow when it swells or bursts. For winter use six-inch flower pots or small boxes and place in kitcher

106. Market Gardener's Best Triple-Curled. The plant is of a rery robust and free growth, and it is improved by severe cutting. The leares are very large and beautifull curled, and of a rery dark green. It will stand the heat, drought and cold better than many other varieties. Pkt. 5 and $10 \mathrm{cts.;}$ oz. $15 \mathrm{cts}$.; T/4 lb. $30 \mathrm{cts}$; $1 \mathrm{lb} .90 \mathrm{cts}$.

C33. Emerald, or Dwarf Extra Curled. Leares are tender, beautifully curled; handsome, bright green color; rery pretty; makes long stems. Pkt. 5 and 10 cts.; oz. 15 I/4 lb. 25 cts.; lb. 75 cts.
A 106. Green Mountain.

Hardy, immensely productive, $d$ e e $p$ relvet green. The leares are d e n s el $y$ curled and borne in abundance. Is exceedingly eas 5 to grow, and with very little care any one can hare the finest parsley in cultivation. If you have but a few square feet of garden, you can easily raise enough parsley to sup ply sour table. Pkt. 5 and 10 cts.; oz. 15 cts.; $1 / 4$ lb. 30 cts.; lb. $\$ 1.00$.

218 . Plain, or Single. Leares flat, deeply cut, but not curled, and rers dark green. Plant vers hard. One of the most popular rarieties for Southern culture. A good producer of excellent quality garnish. Pkt. 5 and 10 cts.; oz. 15 cts.; $1 / 4$ lb. 25 cts.; lb. 75 cts.

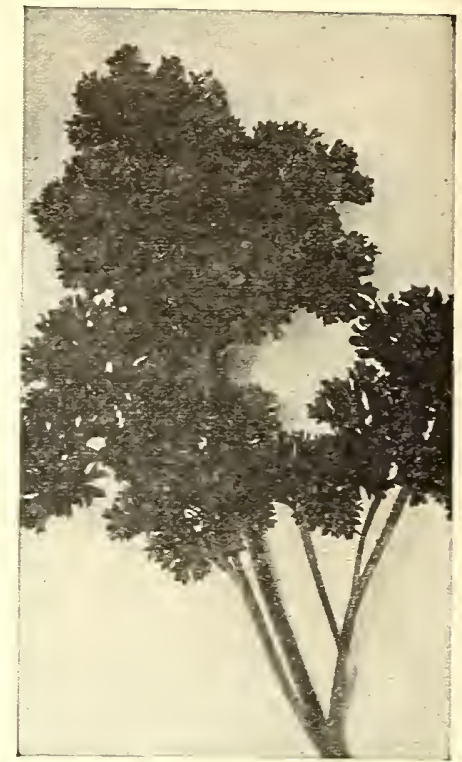

One Ounce Will Sow PAPSP For an Acre.
200 Feet of Dill.

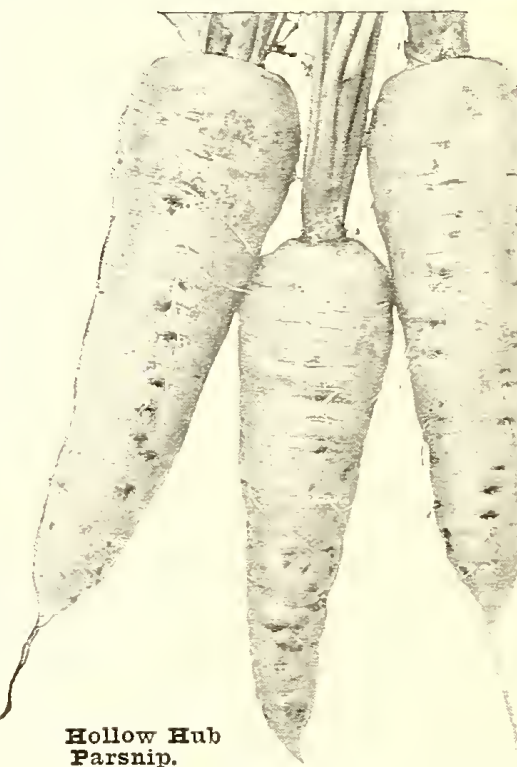

CUITURE. Sow as early in the spring as weather will permit in drills 15 inches apart in rows. The quality of the roots is improved by leaving them in the ground over winter for spring use. Secure nough in pits or cellars for immediate needs. Valuable for feeding as well as for table use.

\section{Hollow Crown} Sugar. Parsnip, or Hollow Hub. The best and handsomest parsnip. Half long, wedgeshaped, hollow crowned. and rel'y broad at the shoulders, easily taken out of the ground, and producing more tons to the acre than the longer and thin rarieties. Pkt. 5 and 10 cts.; 0z. 15 cts.; $1 / 2$ lb. 40 cts.; lb. 75 cts.

Guernsey. A greatly improved strain. Hollow crown. rery smooth. Pkt. 5 and $10 \mathrm{cts}$; 0z. $15 \mathrm{cts} . ; 1 / 4$ lb. 25 cts.; lb. 75 cts.

\section{FREE DELIVERY}

Packets, Ounces, Quarter=Pounds, of all seeds ex= cepting Beans, Corn, and Peas ordered at list prices, will be sent Free by Mail or Express.

Los Angeles, Cal., April 7, 1921.

F. W. BOLGIANO \& CO.

Washington, D. C.

Dear Sirs,--Just to thank you for the seeds and Lilly Pips. Some of the seed are up and the Lillies are doing fine.

Next year I hope to get a good many seed from you. Yours truly, MRS. GRACE VAYO. 

One and One-Half Bushels
to the Acre.

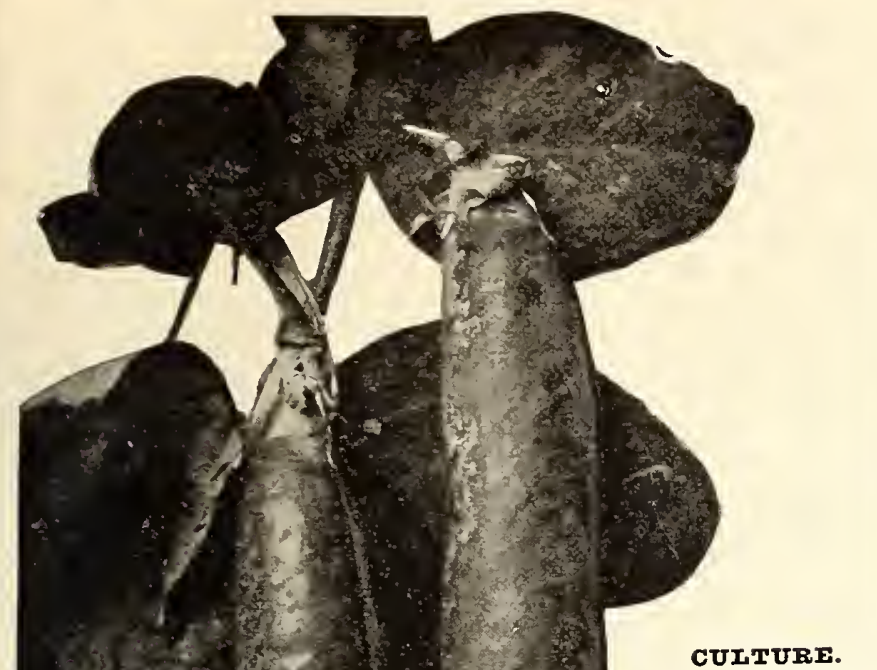

CUITURE.

$P$ e a s mature earliest in light, rich soil. For general c r op
use a rich, deep use a rich, deep ing to clay is bes $t$. Whe $n$ grown in garden sow in double rows 6 to 8 ins. apart; the rows 2 to 4 commence sowing the extra early $v$ a $r$ i t ies as e a r ly as the ground can be worked in. Feb-

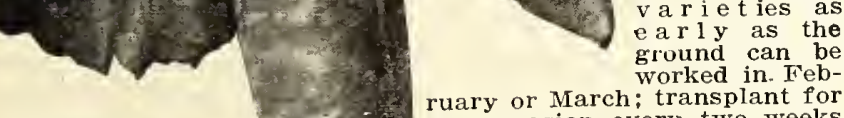
Early Bird Peas.
Bolgiano's $100 \%$ Profit Peas. Only grows 1 foot high, but quickly produces an abundance of immense beautiful deep green pods, filled with large delicious peas. "100\% Profit" Peas are much earlier, dwarfer, more prolific, deeper green color, and more delicious in flavor than either the Thomas Laxton or the Gradus Pea. Will make a lot of money quickly for the market gardener and shippers to Northern markets. As a pea for the home garden it is beyond description. Pkt. 10 cts.; pt. 25 cts.; qt. 45 cts.; peck, $\$ 2.85$; bushel, $\$ 10.50$.

Nott's Excelsior. Pkt. 10 cts.; pt. 25 cts.; qt. 45 cts.; peck, $\$ 2.75$; bushel, $\$ 10.00$.

Premium Gem. This variety is nearly as early as the American Wonder, and the vine is decidedly larger, growing from 12 to 16 inches, and bearing an immense crop of peas which are larger and invariably filled with peas of best quality. Pkt. 10 cts.; pt. 25 cts.; qt. 40 cts.; peck, $\$ 2.60$; bushel, $\$ 9.50$.

American Wonder. This variety stands unrivaled in point of productiveness, flavor and quality, and is without exception the earliest wrinkled pea in cultivation. It is of dwarf and robust habit, growing from 10 to 15 inches high, and produces a profusion of good-sized and well-filled pods of finest flavor. Pkt. 10 cts.; pt. 25 cts.; qt. 40 cts.; peck, $\$ 2.60$; bushel, $\$ 9.50$.

McLean's Little Gem. Very early, prolific, delicious flavor. Height $1 \frac{1}{4}$ feet. Pkt. 10 cts.; pt. 25 cts.; qt. 45 cts.; peck, $\$ 2.75 ;$ bushel, $\$ 10.00$.

\section{Extra Early Varieties}

Early Springtime Peas. Introduced by us four years ago. It is long podded with large peas, fine quality, abundant cropper. Full description on page 5 of this catalogue. Pkt. 10 cts.; pt. 30 cts.; qt. 50 cts.; peck, $\$ 3.50$; bushel, $\$ 12.00$.

Extremely Early Long-Podded Alaska. an entirely new, vigorous, handsome, long-podded, delicious flavored Alaska pea. Bound to become extremely popular, for it has all the good qualities of our Famous Extra Early Alaska Pea, and in addition it has a well-filled long pod, which will fill the basket quickly, and while it is not a distinctly sugar pea, yet it has a much sweeter flavor than the Alaska. It is abundant yielder. Pkt. 10 cts.; pt. 25 cts.; qt. 40 cts.; 4 qts. $\$ 1.40$; peck, $\$ 2.60$; bushel, $\$ 9.50$.

Extra Early Alaska. The earliest of all smooth green peas, having the best color when shelled and the best quality when cooked. The dark green color of the pods make it extremely desirable, as it can be carried long distances without losing its color, which quality, combined with its earliness and uniformity of ripening, make it one of the best early peas for market gardeners. Pkt, 10 cts.; pt. 25 cts.; qt. 40 cts.; peck, $\$ 2.25$; bushel, $\$ 8.00$.

Bolgiano's Extra Early Triumph. The earliest of all; uniform and productive. The success of our Extra Early Triumph Peas has been surprising. Large truckers hate found it most satisfactory. Pkt. 10 cts.; pt. 25 cts.; qt. 40 cts.; peck, $\$ 2.40$; bushel, $\$ 8.50$.

Prolific Early Market. Not quite so early as the Pedigree, but much more productive. Beautiful large pods, fine quality, one of the best peas ever introduced. Height $2 \frac{1}{2}$ feet. Pkt. 10 cts.; pt. 25 cts.; qt. 40 cts.; peck, $\$ 2.25$; bushel, $\$ 8.00$.

Wonderful Extra Early. This pea has proven itself to be a decided acquisition to the list of peas. It is as early as the Alaska; bears long, well-filled pods. While not a wrinkled pea, it takes somewhat of the character of these. It can be planted as early as the Alaska-vines grow stiff and upright. Pkt. 10 cts.; pt. 25 cts.; qt. 40 cts.; peck, $\$ 2.60$; bushel, $\$ 9.00$. 


\section{PEAS-Extra Early Varieties}

Pilot Peas.

As early as the best selected, small. and smooth seeded extra early rarieties. Pods and peas are nearly as large as those of the riradus and produreed three d a 5 (arlier. Pkt. 10 cts. pt. 25 cts.; qt. 45 cts.; peck, \$2.85; bushel, $\$ 10.50$.

Extra Early Gradus. or PROS= PERITY. The rery best extra early wrinkled pea erer" introduced, It produces pods equal in $\therefore i z$ e to the rellkil o mn Teiephone. Quality and productiveness e q u a l to $\mathrm{t}$ h a $\mathrm{t}$ well - known
rariets. The Fines are of rigorons, robust growth, about 216 feet high, thick stems and Iuxuriant toliage; bears large, handsome pods with i $\mathrm{m} \mathrm{m}$ e nse luscious peas, $r$ e m a i $n$ ing sweet and tender Inng time after thes are fit to pick. Pkt. 10 cts.; pt. 25 cts.; qt. 45 cts.; gallon, $\$ 1.50$; peck, $\$ 2.85$; bushel, \$10.50.

\section{Eytra Early}

Thomas Laxton.

An extra early win kled marrom of excellent quality, and a valuable addition to the rely early rarieties. It is three feet high and somewhat more rigorous in habit than Pros-

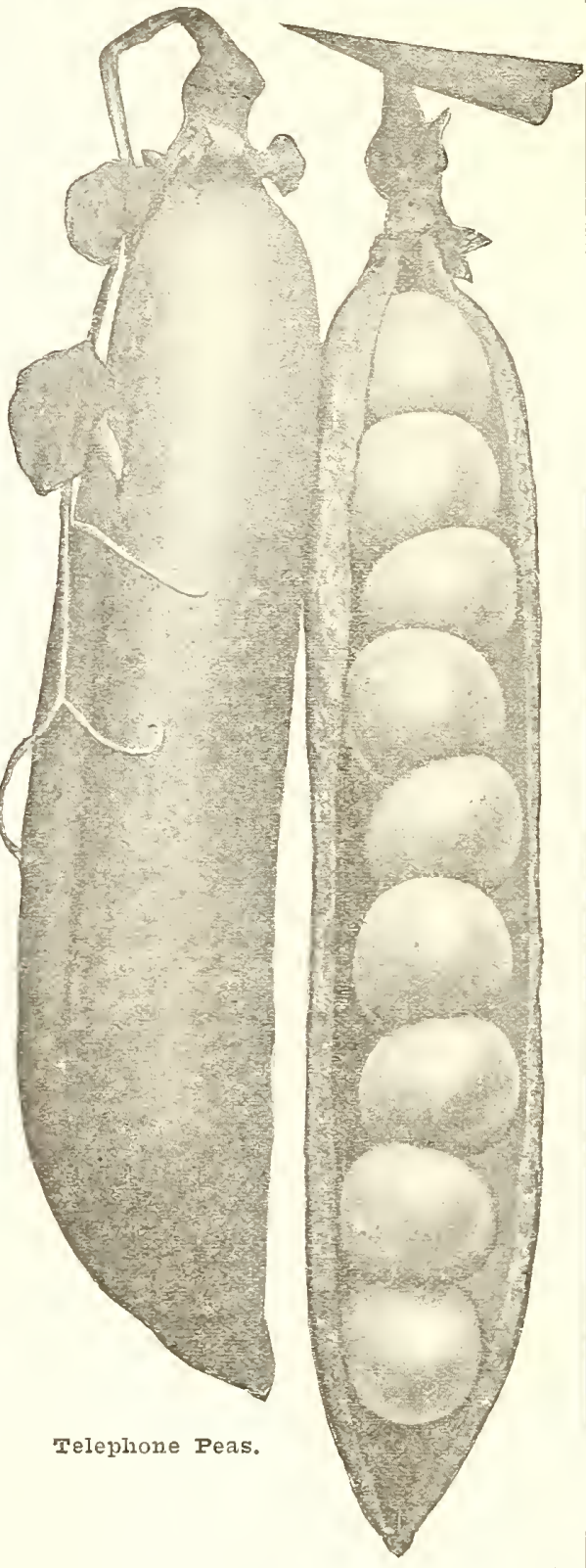

perity. The pods are medium to large. blunt-ended and filled to the tip with large veas of true, rich "marrow" flarol. Its strong rine and hears cropping character make it very suitable for an early crop in the prirate garden. It mar be used to great adrantage as an immediate successor to Gradus. If somn together. Thomas Laston will be in full production just as the crop of Gradus is diminishing. Pkt. 10 cts.; pt. 25 cts.; qt. 45 cts.; gallon, $\$ 1.50$; peck, $\$ 2.85 ;$ bushel, $\$ 10.50$.

First and Best. Pkt. 10 cts.; pt. 25 cts.; qt. 40 cts.; peck, $\$ 2.25$; bushel, $\$ 8.00$,

Ameer. Fine podded Extra Early; prolific. Pkt. 10 cts.; pt. 25 cts.; qt. 40 cts.; peck, $\$ 2.60 ;$ bushel, $\$ 9.00$.

Bountiful. Bear's an abundance of beautiful green pods, crowded with delicious peas. Extremely earls. Height $2 \frac{1}{2}$ feet. Pkt. $10 \mathrm{cts}$; pt. 25 cts.; qt. 40 cts.; peck, $\$ 2.50$; bushel, $\$ 9.00$.

\section{Second Early or General Crop}

Bolgiano's New Victory Pea. When we first obtained this remarkable pea we had only a few rines with which to start, and we saw at once it was the pea marliet gardeners are longing for. The rines are deep dark sreen in color. rery luxuriant in appearance. Pods $5 \frac{1}{2}$ to 6 inches long, filled with beatifnI deep dark green peas of large size and most delicious flaror. The pods retain their deep dark green color long after picking. Its heartiness and fine delicious flaror will make it a farorite with the home gardeners. See pagè う. Pkt. 10 cts.; pt. 30 cts.; qt. 50 cts.; peck, $\$ 3.50$; busnel, $\$ 12.50$.

Telephone. A rrinkled rariet. of rery robust habit and a sreat bearer. A single rine produces from $\&$ to 10 unusually long. Well-filled pods of largest size, containing 10 to 11 peas. It is rerr prodnctire, of fine flaror and an excellent table rariet. Height about 4 feet. Pkt. 10 cts.; pt. 25 cts.; qt. 45 cts.; gal. \$1.60; pk. \$3.00; bus. \$11.

Cracker Jack Pea. A wonderfuI rielder with robust. hards rines that - withstand the summer heat Iong after other rarieties are dried up. It has an abundance of large dark green pods. Ready for the market just as Wonder Worker is over. As a good heat resister it is the pea that market gardeners hare been looking for. and is truly a "Crackel' Jack." Pkt. 10 cts.; pt. 30 cts.; qt. 50 cts.; peck, \$3.50; bushel, \$12.00.

Horsford's Market-Garden. Verr prolific. Pt. 25 cts.; qt. 40 cts.; peck, $\$ 2.35$; bushel, $\$ 8.50$.

Champion of England. A rell-known standard. Pt. 25 cts.; qt. 40 cts.; peck, $\$ 2.50$; bushel, $\$ 9.00$.

Alderman. Tall, rigorousls productice. Pt. 25 cts.; qt. 45 cts.; peck, $\$ 3.00$; bushel, $\$ 11.00$.

Duke of Albany. One of the largest podded peas; vers productire. Pt. $25 \mathrm{cts}$; qt. $45 \mathrm{cts}$; pk. $\$ 2.85$; bus. $\$ 10.50$.

Juno (Dwarf Champion). Late: laire pods: prolifie. Pt. 25 cts.; qt. 45 cts.; peck, $\$ 2.40$; bushel, $\$ 9.50$.

Each of the five varieties above, $10 \mathrm{cts}$. per pkt.

Improved Stratagem. The pods are of immense size and uniformly filled with rery large. dark green peas of the finest quality. All the good qualities of the old stratagem are highly dereloped, and it is superior to the stock now generally sold as Stratagem. Tine medium height, but rery stock. with rery broad. light green leares and bearing an abondance of large, handsome pods. Pkt. 10 cts.; pt. 25 cts.; qt. 45 cts.; peck, $\$ 2.75$; bushel, $\$ 10.00$.

\section{Wonder Worker (Bolgiano's Earliest Wrinkled Pea).} The most delicions pea fou hate erer eaten. Six weeks from planting. this wonderful large wrinkled pea can be maketed. In earliness. great size and excellent flaror it is unequalled. The rines grow $21 / 2$ feet high, and are rery hardy. resisting pests and cold weather. It bears an abundance of large, eren. deep green pods. Pkt. 10 cts.; pt. 25 cts.; qt. 45 cts.; peck, $\$ 3.00 ;$ bushel, $\$ 11.00$.

Early Morning Star. Ters ealy: fine crop. Pkt. 10 cts.; pt. 25 cts.; qt. 40 cts.; peck, $\$ 2.25$; bushel, $\$ 8.50$.

Pedigree Extra Early. Select of First and Best. Pkt. 10 cts.; pt. 25 cts.; qt. 45 cts.; pk. $\$ 2.25$; bus. $\$ 8.50$.

Everbearing. A long time in benring. Peas large, pods long; 11/2 feet high. Pkt. 10 cts.; pt. 25 cts.; qt. 45 cts.; peck, \$2.75; bushel, \$10.00.

\section{PEAS_-Edible-Podded or Sugar}

Melting Sugar. Grows to height of 5 feet; bears a profnsion of large. broad pods. which are so brittle they snap withont any string. Should be used in mnch the same way as a wax bean. Lods when cooked are rers sweet and tender. Pkt. 10 cts.; pt. 25 cts.; qt. 45 cts.; gallon, $\$ 1.50$; peck, $\$ 2.75$. 


\section{PEPPER}

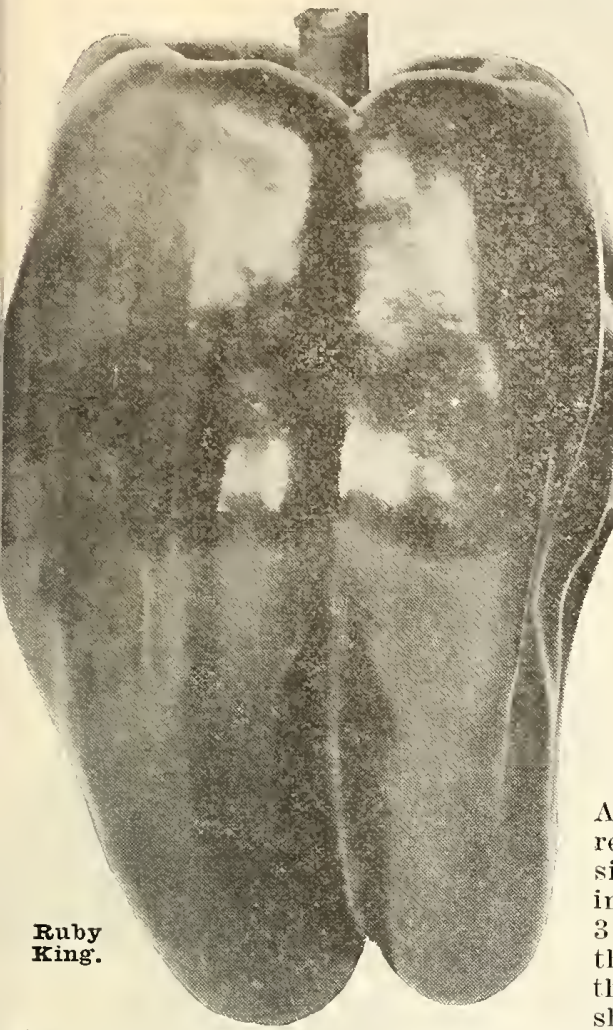

One Ounce Will Produce

About 1,500 Plants.

35. Royal King. An improved liuby Kinc, foul lobed, bright color, mild and sweet. This variety, to our minds. far surpasses any recent types on the mirket. Pkt. 5 and 10 cts.; oz. 40 cts.; $1 / 4$ lb. $\$ 1.25 ; 1$ lb. $\$ 4.50$.

14. Chinese Giant. This monstrous fruiting variety averages 12 to 15 inches in circumference and, notwithstanding its immense size, it is very early and prolific. The stocky, well-branched plants, about 2 feet lich, carry so many peppers that in places they seem bunched together. The flesh is thick, tender, mikl, sweet and mexcelled when sliced or for stuffing for "mangoes.' When ripe the surface is of a brilliant, varnished scarlet. Pkt. 5 and 10 cts.; oz. 45 cts.; I/4 lb. $\$ 1.50 ;$ lb. $\$ 5.50$.

25. Bell, or Bull Nose. Produces a very large - sized pepper, which is highly esteement for pickling. Flesh is sometimes quite hot in flavor. Pkt. 5 and 10 cts.; oz. 35 cts.; $\quad 1 / 4$ lb. $\$ 1.15 ; \quad$ lb. $\$ 4.00$.

"Scarlet Mammoth" Pepper. The largest, earliest maturing and most productive, very large, sweet Pepper. The plant is vigorous and upright, growing larger than that of the Chinese Giant and produces much more fruit. The fruits ripen earlier than any of the very large sorts on the market, and average heavier, as the flesh is unusually thick. Color deep crimson when matured; flavor very mild. Pkt. 5 and 10 cts.; oz. 45 cts.; $1 / 4$ lb. $\$ 1.50 ;$ lb. $\$ 5.50$.

183. Pimento. Undoubtedly the thickest fleshed of all peppers. The peppers are of just the right size, measuring about $31 / 2$ inches long by $2 \frac{1}{4}$ inches across the stem, being decidedly conical in shape, and are of a rich bright scarlet color. The meat or flesh is tender and sweet. Pkt. 5 and 10 cts.; oz. 35 cts.; $1 / 4$ lb. $\$ 1.15 ;$ lb. $\$ 4.00$.

4. Long Red Cayenne. A long red variety, very hot, and is generally used for seasoning soups. Pkt. 5 and 10 cts.; oz. 35 cts.; 1/4 lb. $\$ 1.15 ;$ lb. $\$ 4.00$.

17. Red Chili. They are pointed like the Cayenne, but not so long nor so thick, and are exceedingly pungent when ripe. Requires a long, warm season. The plants should be started early in a hotbed. Pkt. 5 and $10 \mathrm{cts}$.; oz. $40 \mathrm{cts}$.; I/4 Ib. $\$ 1.25 ;$ lb. $\$ 4.50$.

size. It is rery bright colored and the flesh is sweet an $\$ 1.25 ; \quad$ Ib. $\$ 4.50$.

12. Sweet Mountain. Fruit sweet and very large, often 6 inches or more in length by 2 inches in diameter; very smooth. Pkt. 5 and $10 \mathrm{cts} . ;$ oz. $40 \mathrm{cts}$; $1 / 4$ lb. \$1.25; lb. $\$ 4.50$.

Hills, Eight
Feet Apart.

C59. Small Sugar. A very handsome little pumpkin with deep orange-colored skin and flesh of usually fine, sugary flavor; fine-grained, very productive, and keeps well. Pkt. 5 and 10 cts.; oz. 15 cts.; 1/4 lb. 25 cts.; lb. 85 cts.

126. Large Sweet Cheese. A most popular variety ; fruit flattened; skin mottled light green and yellow, changing to rich cream color as it matures. Flesh yellow, thick and tender. Pkt. 5 and $10 \mathrm{cts} . ;$ oz. $15 \mathrm{cts}$; $1 / 4$ lb. 25 cts.; lb. 85 cts.

C36. Sweet Potato. The finest variety for table use. Pkt. 5 and $10 \mathrm{cts}$; 0 . $15 \mathrm{cts}$; $1 / 4$ lb. $30 \mathrm{cts}$; $1 \mathrm{lb} .75 \mathrm{cts}$. 158. Connecticut Field, or Large Yellow. The common field variety. Excellent for feeding. Pkt. 5 and 10 cts.; oz. 15 cts.; 1/4 lb. 25 cts.; lb. 75 cts.

Kentucky Large Field. Flat, fine for pumplin pies, winter, etc. Pkt. 5 cts.; oz. 10 cts.; 1/4 lb. 20 cts.; Ib. 60 c.

75. Yellow Winter Crookneck. Fruits are about $2 \mathrm{ft}$. long, with solid, meaty, curvy neck. Seed located in bulblike end; color solid yellow. Pkt. 5 and 10 cts.; $0 z .15$ cts.; $1 / 4$ lb. 35 cts.; lb. $\$ 1.25$.

C20. Green Striped Cushaw. Fruits very large, with crooked neck. Color creamy white, irregularly striped or traced with green. Flesh light yellow, very thick, rather coarse but sweet. 'This sort is rery productive and popular in some sections. Pkt. 5 and $10 \mathrm{cts.;}$ oz. $15 \mathrm{cts}$; 1/4 lb. 35 cts.; lb. $\$ 1.25$.
CUITURE: May be planted middle of spring, among the Indian corn or in the field or garden, in hills 8 to 10 feet apart each way, four seeds in a hill. In other respects they are cultivated in the same manner as melons and cucumnear other varieties.

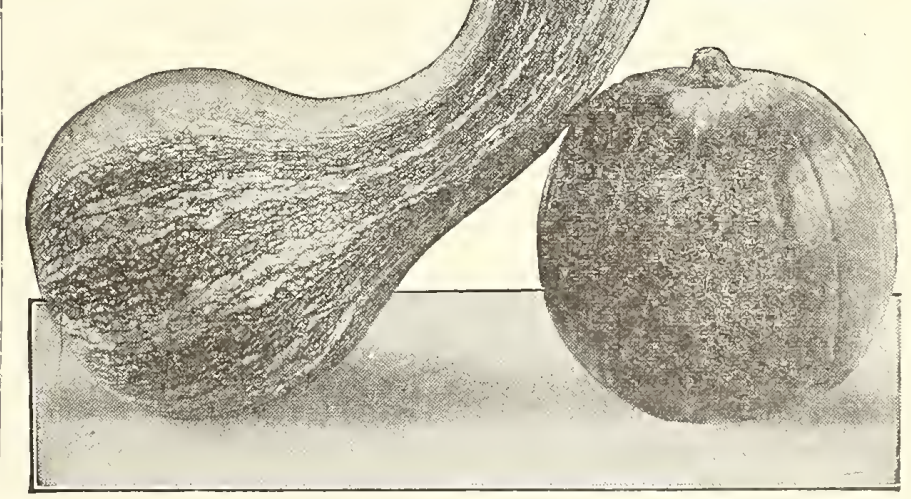

King of the Mammoth, or True Potiron. T h e great prize pumplin growing the largest of all, from 100 to 200 pounds in weight, hright yellow, tender, excellent. Pkt. 5 and $10 \mathrm{cts}$; $0 \mathrm{z} .15 \mathrm{cts} . ; \quad 1 / 4 \mathrm{lb} .30 \mathrm{cts}$; Ib. $\$ 1.00$. 


\section{MAINE SEED POTATOES}

The HOULTON (MAINE) SEED POTATOES аге universally acknowledged to be the best; grown in the cold North, where Nature conspires against all but the strongest. we. get our best seed. For earliness and productireness we are convinced that Maine-grown seed are the best, and, in the long run, cheapest. Why not take the same care in selecting your seed potatoes as you would your cabbage? Our stocks hare been grown for seed purposes, and are carefully selected for yield and purity. Get our prices before rou buy. Several hare told us that see gotten from our house vields from $20 \%$ to 25 ? more than seed sared by themselves.

If shipments are requested during serere cold weather, the tubers trafel solely at mrchaser's risk.

Trust Buster (Bolgiano's new extra early seed potato). The great success of this new potato is assured from the wonderful reports we have received the last few rears. It is not only early, but it is a heary producer of potatwes of the very finest texture and quality. These potatoes are uniform in size, color, and fine flavor. They are quickly prepared for cooking, as the skin peals readily and they cook dry and mealy. Peck, $\$ 1.00$; bushel, $\$ 3.40$; barrel, $\$ 8.50$.

Irish Cobbler. The most popular of the early rarieties. Of handsome cream white color and of excellent quality, making it most desirable for the best trade. It is a vigorous grower, ripens uniformls, and is a good keeper. Peck, \$1.00; bushel, \$3.25; barrel, \$8.00.

Houlton Early Rose. This is a popular potato; rery early: fine quality, and rery productive. Peck, $\$ 1.00$; bushel, $\$ 3.25$; barrel, $\$ 8.00$.

XX Early, or Early Ohio. This is a potato that comes to us rery highly recommended-one of the finest, practically free from blight; rose color; productive. Peck, $\$ 1.00$; bushel, $\$ 3.25$; barrel, $\$ 8.00$.

Red Bliss Triumph, or Improved Red Bermuda. One of the earliest varieties grown; its great productiveness, handsome color and resistance to disease make it most popular. Peck, \$1.00; bushel, \$3.25; barrel, $\$ 8.00$.

"Prosperity" (the best second early and main crop potato). Yields great crops of eren, fine, smooth, large potatoes, eren under the most unfarorable circumstances, and can be relied upon to bring in good money. The flesh is as white as snow, and cooks dry and mealy. The eyes are eren with the surface, the skin white, with rich, rellowishcreamy cast, and considerably ruffled or netted. Peck, $\$ 1.00$; bushel, $\$ 3.40$; barrel, $\$ 8.50$.

Green Mountain, or State of Maine. The best main crop potato now on the market; fine sielder; fine flaror; fine appearance. Free from blight and rot. Keeps well, and is always ready for the table. Peck, \$1.00; bushel, \$3.25; barrel, $\$ 8.00$.

Spalding. Earliest Rose White in the world; good cropper; fine appearance. Peck, \$1.00; bushel, \$3.25; bbl. \$8.

American Giants. One of the most popular of the new heavy yielding potatoes. Pk. $\$ 1$; bus. $\$ 3.25$; bbl. $\$ 8$.

Burbank Seeding. An old standard, popular on account of its fine eating quality. Pk. $\$ 1$; bus. $\$ 3.25$; bbl. $\$ 8$.

Early Round Six Weeks. Ready for table in six weeks. Peck, $\$ 1.00$; bushel, $\$ 3.25$; barrel, $\$ 8.00$.

Ensign Bagley, or White Rose. An excellent cropper, smooth, not susceptible to disease. Peck, $\$ 1.00$; bushel, $\$ 3.25$; barrel, $\$ 8.00$.

\section{ALL PRICES SUBJECT TO MARKET CHANGES}

Plucky Balumore. Snowy white, about the size and shape of the Houlton Early Rose. They are enormously productire, rielding as much as 250 to 350 bushels per acre of most attractire, marketable potatoes. Peck, $\$ \mathbf{1 . 0 0}$; bushel, $\$ 3.40$; barrel, $\$ 8.50$.

Gray's Mortgage Lifter. It is an early variety, pure white, large handsome size, distinctire in shape, being long, well filled and tapering at both ends. Eyes are strong and well set, not too deeply, howerer. It certainly is a beauty. Peck, $\$ 1.00$; bushel, $\$ 3.40$; barrel, $\$ 8.50$.

McCormick. Should be planted in July and early in August. It is one of the heariest sielders. Peck, 85 cts.; bushel, $\$ 3.00 ;$ barrel, $\$ 7.00$.

\section{SWEET POTATO ROOTS}

CUITURE. Don't wait for a rain or a "season" to set out sweet potato plants. Harrow your ground well before laying it off, then throw up the ridges higher than you want them, and if the soil is very dry allow 2 to 3 days for the moisture to rise; then knock off the top of the ridge just ahead of planting; make a mud batter with water and clay loam, or, better, with the addition of fresh cow dung, about as thick as cream; dip the plants, in hands of about 20 ,

Big Stem Sweet Potatoes. They are of fine size, and the yield has astonished our most critical trade. They make only a very few, and in some cases no small roots. The quality is tirst-class.

Jersey Sweet Potatoes. Are too well known to require any description. We get these from reliable growers in New Jersey.

Sweet Potato Plants. Rooted slips ready in May. The young plants should be set in May and June. 
6 Ounces of Seed will

Plant 100 - Yard Row.
RADISH

Eight to Twelve

Radishes are one of the most popular spring and summer vegetables, and it is easy by successive sowings to have a generous supply throughout the entire season.

We have divided the varieties into four classes, and call attention especially to the long-rooted sorts which remain in condition a long time before becoming pithy.

Suggest that you try the White Chinese Winter, sowing the seed the same time as recommended for turnips.

Scarlet Globe Radish.

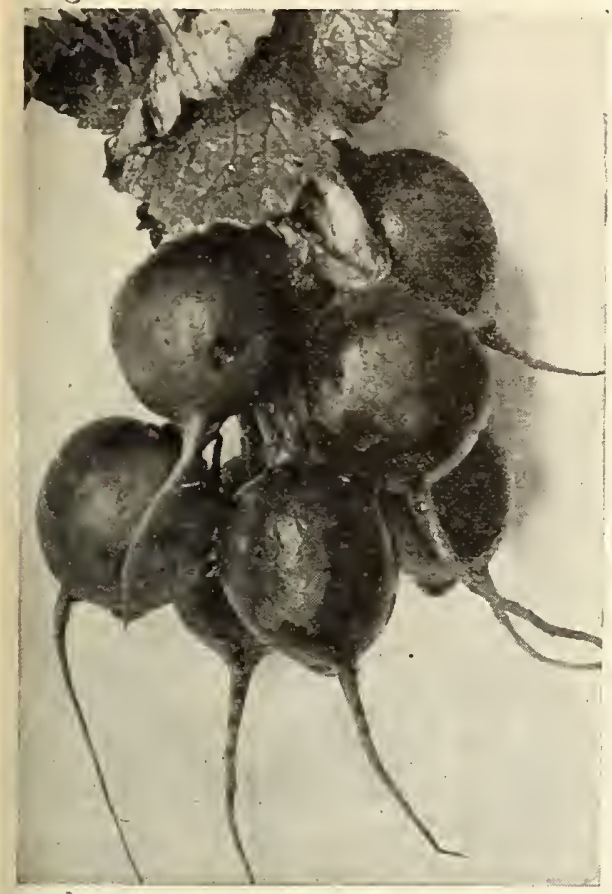

\section{CUITURE.}

Radishes th $\mathrm{r}$ ive Radishes th rive best in a light, rich, mellow soil, and to qualities they must make quick and tender growth. Sow for very early use in hotbeds during the winter and ear 1 y spring or later on in in sheltered borders in el - inanured, leeply-dug and niney-raked soil. If not well stimulated into a rapid growth they become fibrous and tough. Sow in drills 10 inches apart and the rows. Sow at intervals of 2 or 3 tervals of 2 or ber for a ber for a succession. So w winter varieties in July and August. Like the turnips, they make the besi growth in the autumn, and $\mathrm{must}$ be taken out before severe frost and stored a w a in a cool cellar in sand they will keep tender and crisp all the winter. Before using $\mathrm{put}$ in cold water. which adds to their freshness.

\section{Extra Early Round Varieties}

79. Bolgiano's No. 2 Scarlet Globe Radish. Is the very best in every way. It is handsome in form and color, beautiful oval and rich scarlet. The amount of its foliage is small, compared with other varieties, and small for the size of the radish. The peculiar merit of this variety as a forcing radish is that it will bear the heat requisite for forcing without becoming pithy or spongy. The flesh is tender, juicy and mild. It is equally as good for open garden as for forcing, and therefore it commends itself equally to the amateur and market gardener. Pkt. 5 and 10 cts.; oz. 15 cts.; $1 / 4$ lb. 30 cts.; lb. 90 cts.

37. Vick's Scarlet Globe. A forcing radish. Small foliage; quick in growth; fine color and remains solid under all conditions. Pkt. 5 and 10 cts.; oz. $15 \mathrm{cts}$.; $1 / 4$ lb. 25 cts.; lb. 75 cts.

188. Model White Box. An early variety, very popular with market gardeners. Radishes grow 1 and $1 \frac{1}{2}$ inches in diameter, with pure paper-white skin; crisp, mild flesh. Largely planted in the field for the earliest market crop. Pkt. 5 and 10 cts.; oz. 15 cts.; $1 / 4$ Ib. 25 cts.; Ib. 75 cts.

"Strawberry" Radish. A delicious, crisp, brilliant red radish. The very earliest, often ready for market in less than three weeks. It is a perfect globe shape, and so uniform that all the radishes look like they have been made in the same mold. If you have a home garden or if you grow for market, nothing will please you more or give you quicker returns for your efforts than this beautiful radish. Pkt. 5 and $10 \mathrm{cts} . ; \quad 0 z .15 \mathrm{cts}$.; $1 / 4 \mathrm{lb} .30 \mathrm{cts}$.: lb. $90 \mathrm{cts}$.
91. Scarlet Turnip White-Tip Radish. Nature almost exhausted itself in making this beatiful radish to ornament the private table and embellish the market stall. It has been b r $\circ$ ug h t to our market two weeks after planting, and always is a very ea r l y crop for frames a $\mathrm{n}$ f $\mathrm{fo}$ open ground culture. Some gardener's use it in 100 -pound lots. It is annually grown more and more, a $n d$ in demand everywhere. Pkt. 5 and 10 cts.; oz. 15 cts.; $1 / 4$ lb. 25 cts.; lb. 75 cts.

\section{Crimson}

Giant. This new radish is an entirely new type and differs radically from all the

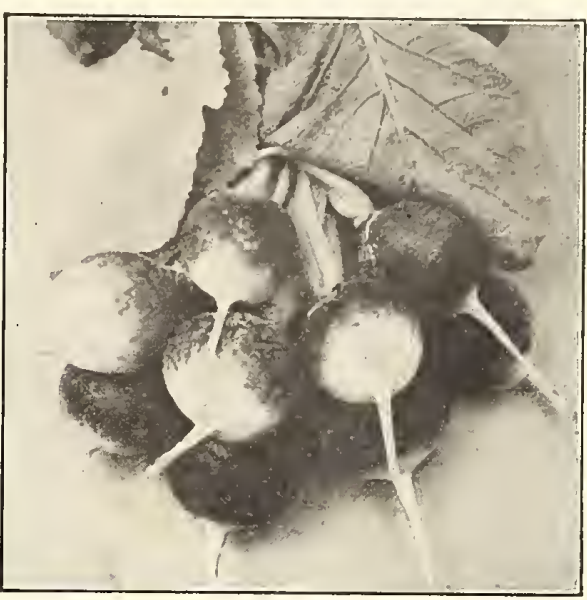

Scarlet Turnip White Tip Radish. valieties hitherto in cultivation, in so far as its roots attain more than double the size of those of other turnip varieties, without getting pithy or hollow. This giant radish develops roots of 6 to 7 inches in circumference and over an ounce in weight, their pure white flesh remaining firm and crisp and of the mildest flavor, but notwithstanding the extraordinary size and weight of the roots. The seed should be sown very thinly to permit full development of the roots. Pkt. 5 and 10 cts.; oz. 15 cts.; I/4 lb. 25 cts.; lb. 75 cts.

Rosy Gem. Everybody wants this pretty, crisp, tast little French radish, so showy with its brilliant cardinal red. contrasted with its immaculate white. Pkt. 5 and $10 \mathrm{cts.;}$ oz. 15 cts.; r/4 lb. 30 cts.; lb. $90 \mathrm{cts}$.

Bolgiano's Round Scarlet Globe Radish. Rich scarlet color, faultless shape, matures in 20 days. Pkt. 5 and 10 cts.; oz. 15 cts.; 1/4 lb. 30 cts.; lb. 90 cts.

10. Scarlet Olive-Shaped. This radish, olive shaped, has a distinct, bright-scarlet color. The whole crop maturing at one time makes it very desirable. It is among the best shippers. Pkt. 5 and 10 cts.; oz. 15 cts.; $1 / 4$ Ib. 25 cts.; lb. 75 cts.

C47. French Breakfast. Elongated olive-shaped roots; color bright carmine with base of root and top root clear white. Pkt. 5 and 10 cts.; oz. 15 cts.; 1/4 lb. 30 cts.; Ib. 90 cts.

\section{Early Long Varieties}

74. Bolgiano's Early Long Red Glass. Quick growth, small top, bright color. The best forcing radish. This brilliant, uniform radish is not so large as the Long Scarlet Radish, but is similar in form and holds its size without losing its nice proportion. Market gardeners find it satisfies the market demands, and sells better than many other long radishes. Pkt. 5 and $10 \mathrm{cts}$; oz. $15 \mathrm{cts}$; $1 / 4 \mathrm{lb} .30 \mathrm{cts}$.; lb. 90 cts.

95. Long Bright Scarlet, or Cardinal. Extra early, the roots being fit for use about 25 days after sowing; very bright color; quite unique; being the most fiery scarlet in any kind of radish. It is very slightly tipped with white, the flesh is crisp and tender. Pkt. 5 and 10 cts.; oz. 15 cts.; $1 / 4$ Ib. 25 cts.; Ib. 75 cts. 


\section{RADISH}

\section{Early Long Varieties}

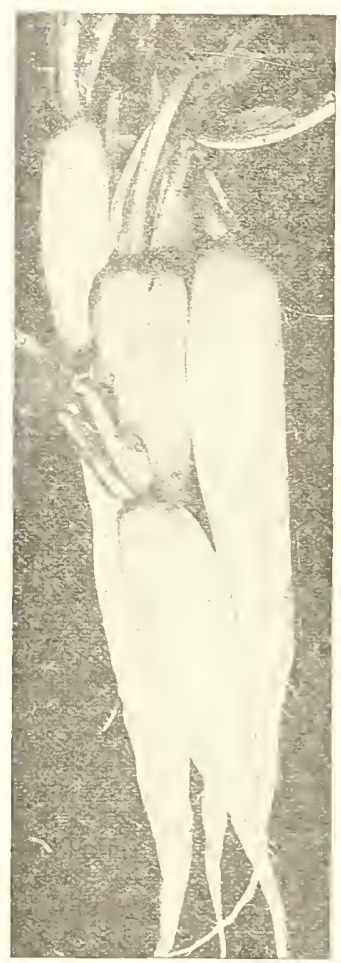

White Icicle Radish.

137. White Icicle. ib. $75 \mathrm{cts}$. A long radish, transparent white, small top, allowing close planting, and are very crisp and brittle. The Radishes remain in good condition for a long time while seowing, allowing continuons use from one planting. Pkt. 5 and 10 cts.; oz. 15 cts.; I/4 lb. 25 cts.;

\section{Improved Early Long} Scarlet Shor: Top. This improved strain of the Long Scarlet Radish is resarded by our most extensive gardeners to be the finest stock srown: for earliness, brillianey of color and shortness of top, it cannot be surpassed, and it is the most profitable one to grow for an early crop. Pkt. 5 and $10 \mathrm{cts}$; 0z. 15 cts.; I/4 lb. $30 \mathrm{cts}$; lb. $90 \mathrm{cts}$.

59. Cincinnati Market. This fine strain of the Long scarlet Short-Top Radish has been selected for thirty years. The tops are so small that the radishes may stand touching each other in the rows. They grow perfectly straight and smooth and from 6 to 7 inches in lensth; and the flesh crisp and brittle and of delightfully pungent flavor. Equally as good for the open ground. Pkt. 5 and 10 cts.; 0z. 15 lb. $75 \mathrm{cts}$.

104. White Vienna, or Lady Finger. A fine $10 \mathrm{ng}$ white viriety. The flasor is mild and sweet. Pkt. 5 and 10 cts.; oz. 15 cts.; 1/4 lb. 25 cts.; lb. 75 cts.

\section{Summer and Autumn Varieties}

These summer radishes at tain a larger size and remain in sood condition for a longer length of time than do any of the earlier round and long varieties.

\section{White Strasburg.}

uf handsome oblong shape tapering beautifully to a point Both shin and flesh are pure w h it e, almost transparent. very tender and of a delightful, pungent taste. It can be pulled five weeks from time of sowing the seed, yet it will continue to grow without los ing its fine quality, and re mains in a tender condition longer than any other summer sort. Pkt. 5 and 10 cts.; oz. 15 cts.; T/4 lb. 25 cts.; lb. $75 \mathrm{cts}$.

\section{Chartier. Long red} radish with a mhite tip. Beautiful for bunching. Pkt. 5 and 10 cts.; oz. $15 \mathrm{cts}$.; $1 / 4 \mathrm{lb}$. 25 cts.; lb. 75 cts.

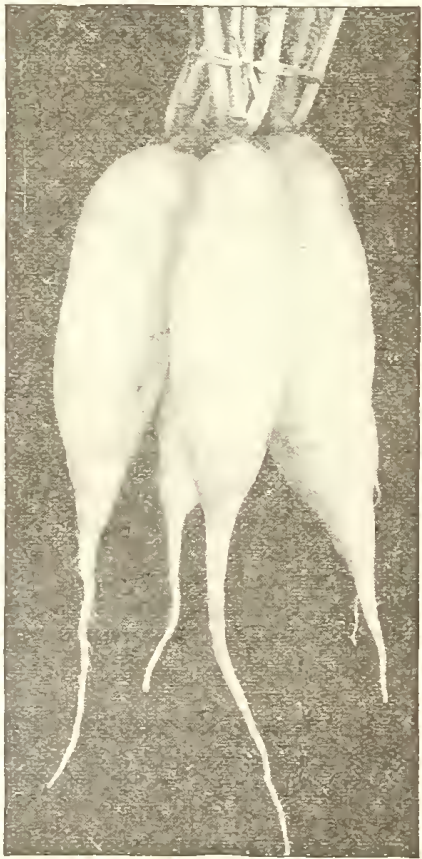

White Strasburg Radish.

\section{Summer and Autumn Varieties}

114. Golden Globe Summer. of globular form and yellow color. A splendid addition to the radish family. Pkt. 5 and $10 \mathrm{cts}$; $0 z .15 \mathrm{cts} . ; \quad \mathrm{I} / 4 \mathrm{lb} .25 \mathrm{cts}$; $1 \mathrm{~b} .75 \mathrm{cts}$.

\section{Winser Varieties}

The seed should not be sown until about July 1st, and if the lows are kept well cultivated the roots continue to make growth until eary in the fall.

78. White Chinese, cr California Mammoth. As solid and juicy as an apple, pure white flesh and delicious flavor -a very choice variety. S h o uld be sown in June and .Tuly, and is ready for use when 3 ins. Iong, and continues to grow until it is 0 ins, long. A firstclass winter radish and always attracts favorable comment at the table or on the $\mathrm{m}$ a r ket stall. Pki. 5 and 10 cts.; $0 z, 15 \mathrm{cts}$.; $1 / 4 \mathrm{lb}$ 30 cts.; lb. 90 cts.

\section{Round Black} Spanish. Roots are ro u $\mathrm{n} \mathrm{d}$, sometimes top-shaped. Go od keeper. Pkt. 5 and 10 cts.; oz. 15 cts.; I/4 lb. 30 cts.; Ib. $90 \mathrm{cts}$.

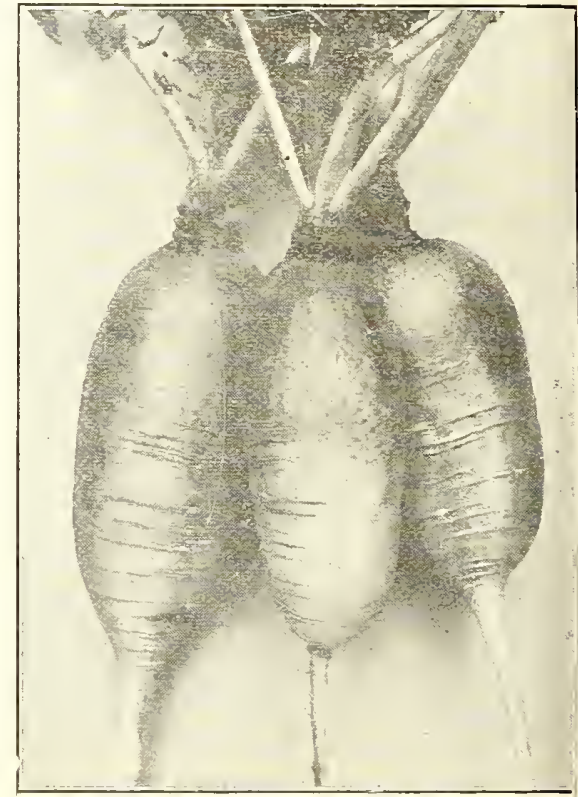

China Rose Radish.
C29. Long Black Spanish. One of the latest and hardiest radishes. Pkt. 5 and $10 \mathrm{cts}$; 0z. $15 \mathrm{cts}$; $1 / 4 \mathrm{lb} .30$ cts.; lb. 90 cts.

157. China Rose, or Scarlet China. One of the most popular fall and winter sorts. Iloots abont 6 inches long. Skin smooth and of a bright rose color. Flesh very firm and crisp. Pkt. 5 and $10 \mathrm{cts}$; 0z. 15 cts.; 1/4 lb. 30 cts.; lb. 90 cts.

\section{RHUBARB}

\section{One Ounce of Seed Produces 500 Plants.}

C42. Victoria. Very familiarly known as the Pie Plant. The foot stalk is the portion that is used and is the first regetable of the season from the garden: cultivated to a great extent and is indispensable wherever it is known. Sow the seen earty in the spring in rows 1 foot apart on rich ground: the second year after planting they can be remored in antumn to the permanent spot allotted to thens: plant the roots 2 feet apart each way in ground that is well enriched. at least 2 feet deep. Pkt. 5 and 10 cts.; oz. 15 cts.; 1/4 lb. 30 cts.; lb. $\$ 1.00$. Roots, $\$ 1.00$ per dozen-add 25 cts. per dozen if sent́ by mail; $\$ 7.00$ per 100 .

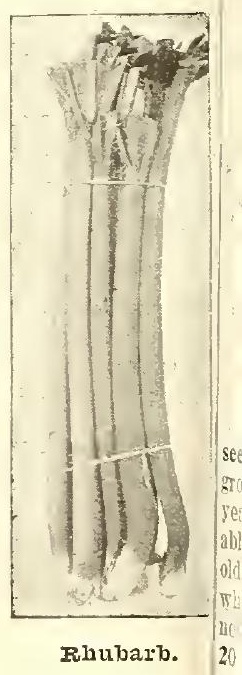




\section{SALSIFY, or OYSTER PLANT}

One Ounce for 50 Feet of Drill; 10 Pounds to an Acre.

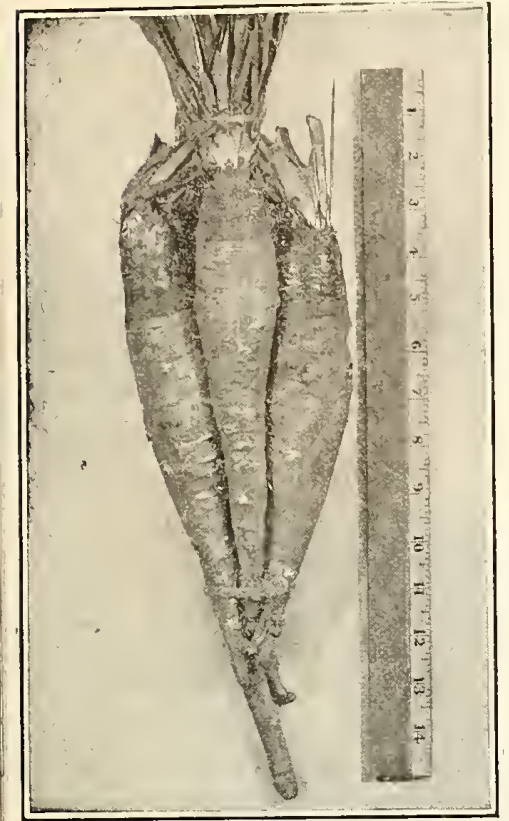

Salsify or Vegrevable Oyster.

CUITURE. A fine vegetable, used the same as carrots or, having been boiled, made into cakes and fried like oysters, which they resemble in flavor. Cultivate the same as carrots and the same as carrots and parsnips. It is hardy, can remain in tho ground all winter for early spring use, but should be taken up be fore it starts growng, take up a supply for use during $\mathrm{n}$ a light, well-enriched, the spring in drills 15 ins. tho spring in druls 15 ins. 6 inches in the rows.

\section{Sandwich Island} Mammoth. One of the most delicious of winter vegetables, and also one of the most nutritious; the flavor is sweet and highly esteemed. This variety. where known, is entirely superseding the old tyve, as it produces roots nearly double the size and weight, and of equally the winter. Succeeds best good quality. Pkt. 5 and $10 \mathrm{cts}$; oz. $20 \mathrm{cts}$; $\quad \mathrm{T} / 4$ lb. $60 \mathrm{cts}$; lb. $\$ 2.00$.

Bolgiano's Great Giant. By far the largest, smoothest, most tender salsify ever sold to the trucker. Its delicious flavor and attractive appearance bring the buyers and holds their trade. It easily outsells every other salsify, and ond tields all other varieties. Truckers who have tried the "Great Giant" say it is ideal. Pkt. 5 and 10 cts.; oz. $20 \mathrm{cts} . ; \mathrm{I} / 4$ lb. $60 \mathrm{cts}$; lb. $\$ 2.00$.

\section{5 to 20 Ibs. ${ }_{4}$ in \\ Drills an Acre. \\ SPINACH}

Two Ounces for

CULTURE. This is an important market gardener's crop, of easy culture. For spring and summer use sow either broadcas or in drills 1 foot apart and 1 inch deep as early as the ground. can be worked, and every two weeks for a succession. For winter and early spring use sow in September in well-manured ground; cover with straw on the approach of severe cold weather. The ground cannot be too rich; the stronger the ground the more delicate and succulent will be the leaves.

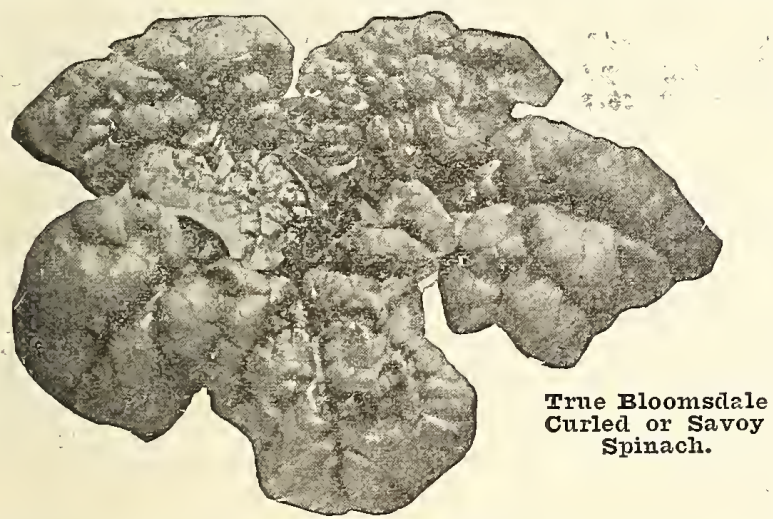

Bolgiano's Selected Bloomsdale Savoy. A mammoth seeded selection that possesses a vitality and, vigor of growth and far outyields any other variety. After many years of tireless effort at breeding we are pleased to be able to offer a limited quantity of this improvement on the old standby. So we would advise your early orders, for when our stock gives out, fou will have to wait until our new crop is harvested. Pkt. 5 cts.; oz. 10 cts.; 1/4 lb. 20 cts.; lb. 50 cts.

\section{SPINACH}

Curled Long Season. A spinach that is curled like the old standard sort, the Bloomsdale Savoy Spinach, yet much more vigorous in growth, large and very handsome. It stands the hot summer heat, and yet has tender leaves. It is positively the best spinach to be grown in the spring and summer. Pkt. 5 cts.; oz. 10 cts.; 1/4 lb. 15 cts.; lb. 35 c.

True Bloomsdale Curled Savoy. Its growth is rapid and leaf is properly curled, which gives it a very attractive appearance. It is the favorite with the largest growers. Pkt. 5 and $10 \mathrm{cts}$.; $1 / 4 \mathrm{lb} .15 \mathrm{cts}$; lb. $35 \mathrm{cts}$.

Improved Curled Long-Standing. The fol $\mathrm{i}$ a $\mathrm{g} \mathrm{e}$ is heary, the broad, dark green leaves are of the finest quality. It is in prime condition from two weeks to three weeks after other varieties of spinach have run to seed. Pkt. 5 cts.; oz. $10 \mathrm{cts}$.; I/4 lb. $15 \mathrm{cts}$; $1 \mathrm{~b} .35 \mathrm{cts}$.

Monstrous, or Viroflay. A valuable variety; has large, round, thick leaves. Pkt. 5 cts.; oz. 10 cts.; $1 / 4$ lb. 15 cts.; !b. 35 cts.

New Victoria Spinach. The foliage is heavy, the broad dark green leaves al'e of the very finest quality. Pkt. 5 cts.; oz. 10 cts.; I/4 1b. 15 cts.; lb. 35 cts.

\section{Spring Spinach。}

The most valuable for spring sowing. its long - standing quality makes it the best for that purpose. The foliage is very attrac tive h e a v y dark gre e $n$, c url ed leaves, of the true Savoy appearance. It will stand from 2 to 3 weels after other varieties of spinach have shot to seed. It can be planted all spring and summer with surety of making a crop. Pkt. 5 cts. oz. $10 \mathrm{cts}$; $1 / 4 \mathrm{Ib}$. $15 \mathrm{cts}$.; $1 \mathrm{~b} .35 \mathrm{cts}$.

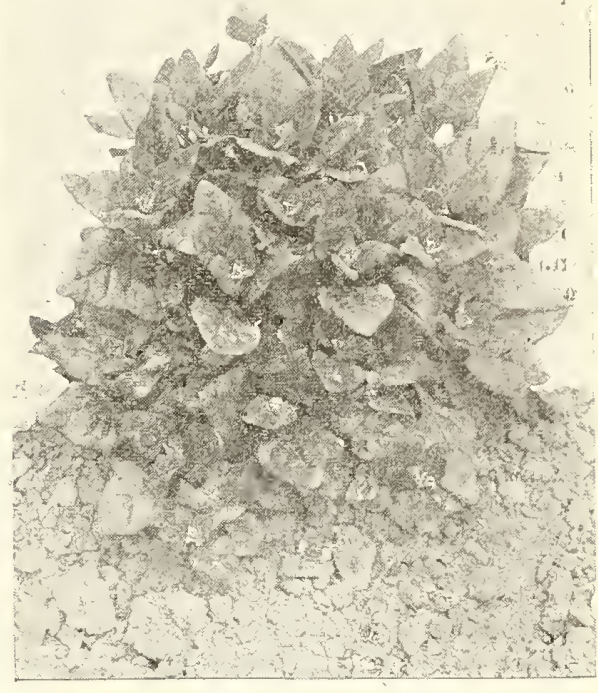

New Zealand Spinach.
C5 1. New Zealand (Tetragonia expansa). Th is is very different in character of growth, and when startèd ealty in the spring the plants will resist hot weather aud prodtee right up until hard freezing weather sets in an abundance of thick, fleshy succulent leares. Pkt. 5 and 10 cts.; oz. 15 cts.; 1/4 lb. 25 cis.; 1b. 75 cts.

\section{TOBACCO}

\section{Choice Selected Seed}

6. CONNECTICUT SEED LEAF. Well-known standard variety. Pkt, 10 cts.; oz. 50 cts.; $r / 4$ lb." $\$ 1.65$; lb. $\$ 6.00$.

184. HAVANA. Grown from imported seed. Pkt. 10 cts.; oz. $50 \mathrm{cts}$; $\quad \mathrm{r} / 4 \mathrm{lb}$. $\$ 1.75 ; \mathrm{lb}$. $\$ 6.50$.

169. IMPROVED WHITE BURLEY. A most popular va riety: Pkt. $10 \mathrm{cts}$; oz. 45 cts.; $1 / 4$ lb. $\$ 1.35 ;-1 b . \$ 5.00$.

182. PENNSYLVANIA SEED LEAF. The variety which is so largely planted in Lancaster Comnty, Pennsylvanias. Pkt. 5 cts.; oz. 40 cts.; $1 / 4$ lb. $\$ 1.10 ; 1 \mathrm{lb} . \$ 4.00$. 
To the Acre: 2 to 3 lbs., Iarge Seeded kinds. Bush kinds, 3 to 4 lbs.

\section{SQUASH}

1 oz. Bush Varieties for 40 Hills. Large Seeded Varieties, 1 oz. 15 Hills.
CUITURF. Sow in hills in the same manner and at the same time as cucumbers and melons, the bush varieties 3 to 4 feet apart, and the running kinds from 6 to 9 feet apart.

There are two kinds of squashes-one for summer use for cooking in the tender green state, and the other for storing for winter use.

Owing to the high cost of meat, one should arrange for a bountiful supply of both the summer and Winter varieties, as the former may be fried and served like egg-plant and the latter are very palatable when stewed and served alone or made into pies.

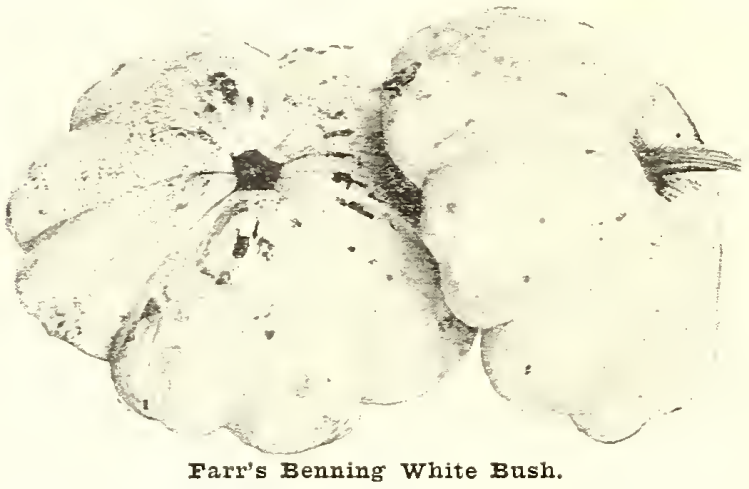

82. Farr's Benning White Bush. It is with great satisfaction that we can continue to offer this unriraled squash. For the past twentr-fire sears this stock has furnished the earliest squash to come on our market. In productireness also it excells other varieties, being an exceptionally hears cropper. The color is a beautiful green tinted white possessed by no other rariety. The flaror is delicious, haring few small seeds and is an excellent cooker. The strain which we offer is that originated br Mr. N. E. Farr and has been grown under our own superrision so as to constantly maintain and improve the qualits. Pkt. 5 and 10 cts.; oz. 15 cts.; I/4 lb. 45 cts.; lb. $\$ 1.50$.

208. Bolgiano's Extra Early Dawn. It is earlier than the majority of the other stocks of Thite Bush Squash, and commands the first Fancs Prices of the earliest market. It is vers productive, and the clear white color is entirely free from any green cast. Fruits are solid and hears, with small seed carits, making excellent shipper. Pkt. 5 and 10 cts.; oz. 15 cts.; I/4 lb. 30 cts.; lb. $\$ 1.00$.

New Extra Early Jersey White Bush. An extra early strain of the Wrhite Bush. Pkt. 5 and 10 cts.; oz. 15 cts.; I/4 lb. 25 cts.; lb. 85 cts.

Golden Custard, or Yellow Bush Mammoth. A rery earls, flat. scalloped variety of largest size: skin a deep orange; flesh pale sellow and well flarored. Pkt. 5 and 10 cts.; 0z. 15 cts.; $1 / 4$ lb. 30 cts.; lb. $\$ 1.00$.

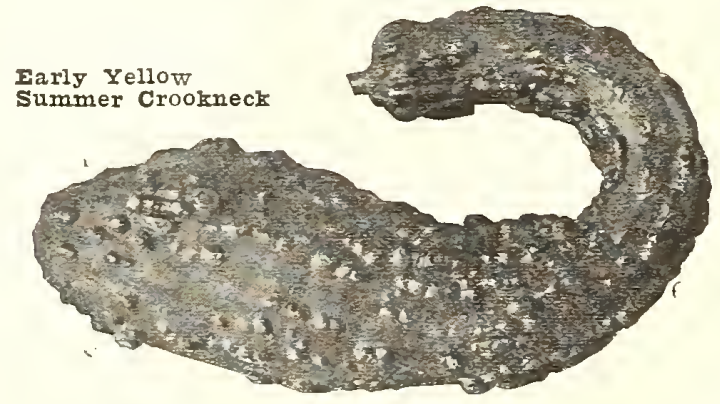

159. Early Yellow Summer Crookneck. A desirable table sort, rery early and productive-fruits when matured small crooknecked and covered with warty excrescences. Pkt. 5 and 10 cts.; oz. 15 cts.; I/4 lb. 30 cts.; lb. $\$ 1.00$.
111. Early White Bush Scalloped, or Patty Pan. This is the earliest: grown almost exclusirely for the first crop. The rind is hard texture, which makes it suitable for shipping and it is exclusicely grown in the South for that purpose. Pkt. 5 and 10 cts.; oz. 15 cts.; 1/4 lb. 25 cts.; lb. $85 \mathrm{cts}$.

O16. Italian Vegetable Marrow. Fine grained flesh of excellent flaror. Fruits large, oblong shaped, dark green at first, but as they mature become maroled with yellow and lighter green stripes. The soung fruits may be fried in oil. Fine grained, tender and of excellent flaror. Pkt. 5 and 10 cts.; oz. 20 cts.; 1/4 lb. 60 cts.; lb. $\$ 2.00$, postpaid.

\section{Winter Squash}

40. Early Prolific Orange Marrow. A comparatively new fall or winter rariety. It is shaped somewhat like the Boston Marrow, but it is a decided improvement on it, being much earlier and more productire. These characteristics will commend this rariets to market gardeners while its brilliant orange-red color and fine keeping and cooking qualities make it popular with the customer. The rind is very hard, but thin, and the flesh deep, fine grained, and of delicato quality. Pkt. 5 and 10 cts.; $0 z .15$ cts.; $1 / 4$ lb. 25 cts.; 1b. $80 \mathrm{cts}$.

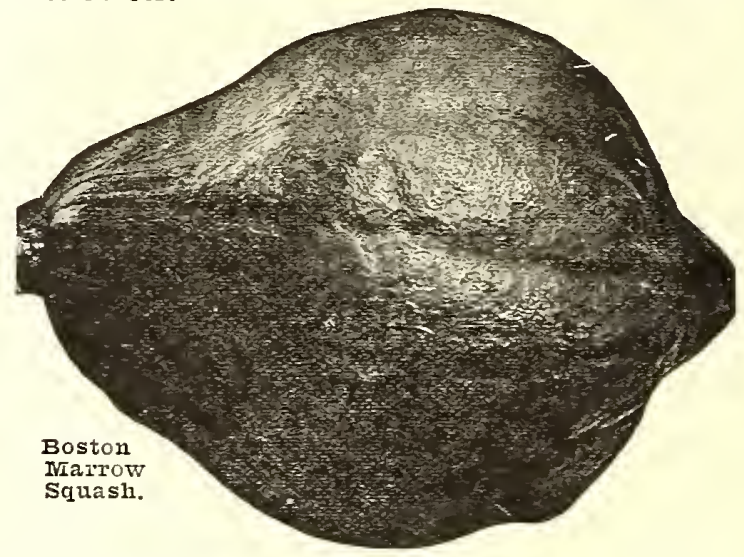

203. Fordhook. This may be grown for summer or Winter use. It is of strong, vigorous growth and extremely productive. The fruits measure 8 to 10 inches long, hare ridged smooth thin brownish-yellow skin; flesh is thick and of a light yellow color. Pkt. 5 and 10 cts.; oz. 15 cts.; 1/4 lb. 30 cts.; lb. $\$ 1.00$.

Chicago Warted Hubbard. A superior strain of mammoth size with skin hearils warted. Pkt. 5 and 10 cts.; oz. 15 cts.; $\quad 1 / 4$ lb. 45 cts.; lb. $\$ 1.50$.

152. Hubbard. A superior rariety and one of the best winter keepers; flesh bright orange-sellow, fine grained, rery drs, sweet and rich flarored. Bakes rery drs, equally as dry as the Sreet Potato. Our stock is the rery best, and we don't hesitate to recommend it to the most critical planter. Pkt. 5 and 10 cts.; 0 . 15 cts.; $\mathrm{I} / 4$ lb. 30 cts.; lb. $\$ 1.00$.

75. Winter Crookneck. Flesh red, fine flavor, largely grown for winter use. Pkt. 5 and 10 cts.; oz. 15 cts.; $1 / 4$ lb. 30 cts.; lb. $\$ 1.00$.

96. Boston Marrow. A splendid winter squash of good keeping qualities. Flesh bright orange, fine grain, and unsurpassed. It is oral-shaped, and thin skin of bright orange color. For pies it is equal to the best pumpkins. Pkt. 5 and 10 cts.; oz. 15 cts.; $1 / 4$ lb. 25 cts.; lb. $80 \mathrm{cts}$. 
Tomatoes represent another important member of the vegetable family. Every garden should have at least one dozen plants, and more if space will allow, as any surplus fruit may easily be canned. Do not overlook the smallfruited sorts-these make delicious tomato butter.

CULTURE. The secd may be started in hotbed in March, or sufficient plants for family use can be grown in pots or boxes indoors with very little trouble. Be particular to give plants the benefit of fresh air and sun whenever judicious, for the purpose of hardening them, and cover with mats when necessary to prevent them from frosting. The two extremes of heat and cold are equally injurious. It is customary with the best ardeners to remove the plants from hotbeds to the cold frames, allowing to remove the plants from hotbeds to the cold frames, allowing a distance of several inches betwcen the plants. In May select and prepare the soil and set the plants will be small. Have the soil very rich. For general erop sow from the middle of April or during May, in the open air, selectng good soil in a location much exposed to the sun and sheltered by a hill or woods on the north.

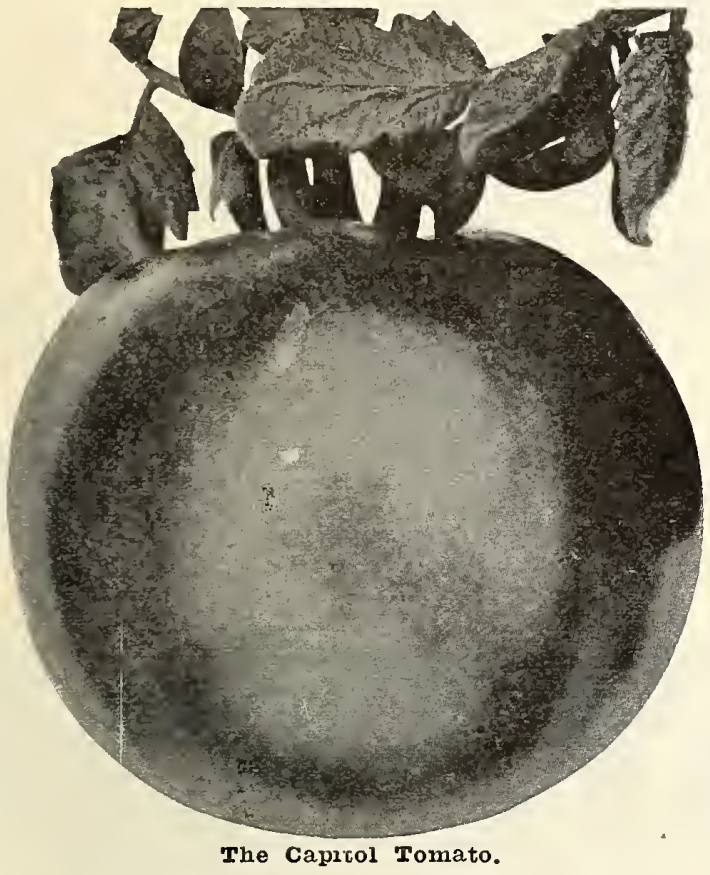

\section{Red Tomatoes}

A67. Bolgiano's Capitol Tomato. The finest introduction since John Baer. Early, heavy producer of deep red perfect fruit. See description on page 3 . Pkt. 25 cts.; 1/2 oz. $\$ 1.25 ; \quad$ oz. $\$ 2.25 ; \quad 1 / 4$ lb. $\$ 7.50 ;$ lb. $\$ 25.00$.

Bolgiano's "Glory" Tomato. Outyields and outsells any Tomato on the market. The yield of "Glory" Tomato is marvelous. Produces at every joint large clusters of good size, smooth, firm, beautifully shaped fruits, uniform in shape, color and size. At times the vines are so full that they can hardly hold all the fruit that they produce. They ripen evenly and color up well. Keep vigorous and green until frost and are then full of fruit. Pkt. 10 and 15 cts.; oz. $\$ 1.50 ; 1 / 4$ Ib. $\$ 5.00 ; 1 b . \$ 15.00$.

155. "Bonny Best" Early. For ten years it has been selected for earliness, solidity, smoothness and evenness of ripening up to stem. 15 days earlier than the Beauty Tomato, and nearly as early as the Earliana. Vigorous grower; bright red color, enormously productive, with a vigorous growth of foliage which protects the fruit from being scalded by the direct sun. Pkt. 5 and $10 \mathrm{cts}$.; oz. $35 \mathrm{cts}$.; $1 / 4 \mathrm{lb}$. $\$ 1.15 ; 16 . \$ 4.00$.

I. X. L. Bolgiano's Extremely Early Tomato. Early, largest, most prolific. Pkt. 5 and $10 \mathrm{cts.;}$ oz. $40 \mathrm{cts}$.; I/4 Ib. $\$ 1.25$; Ib. $\$ 4.50$.

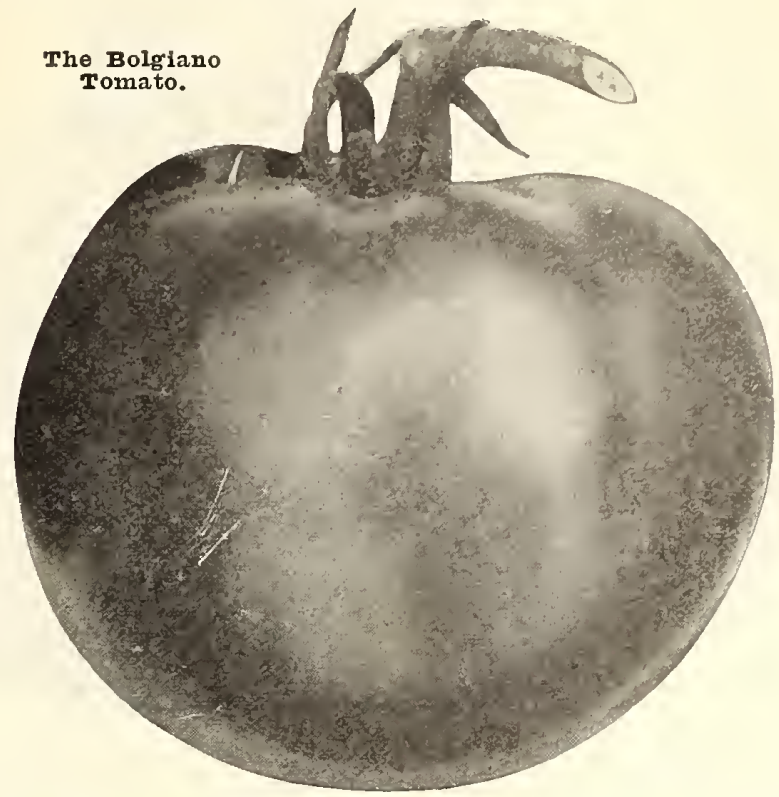

The Bolgiano Tomato. The most wonderful yielder ever known, two weeks earlier than the Earliana. First fruit as good as the prime of the season. A solid mass of red, meaty flesh. Skin tongh, flesh tender and swreet. Stands long-distance shipping perfectly. See description on page 3. Pkt. 25 cts.; 1/2 oz. $\$ 1.25 ;$ oz. $\$ 2.25 ; 1 / 4 \mathrm{lb}$. $\$ 7.50 ; \quad 1 b . \$ 25.00$.

168. Red Cross Blight Resistant Tomato. Its chief advantage is that the vines are resistant to both rust and wilt to a remarkable degree. It has very strong, healthy vines. Thus it becomes a more prolific bearer than other varieties, and the rich scarlet fruit continue to be borne throughout a longer season. Its beautifully shaped fruit and regularity of size particularly recommend it for the most particular narket trade, while its thick, juicy meat and small sparsely seeded cavities will please the most particular appetite. As a variety for both home and commercial use, we feel it has no peer. It is medium in its season. Pkt. 10 cts.; oz. 75 cts.; 1/4 lb. $\$ 2.75 ; \quad$ lb. $\$ 10.00$.

212. John Baer Tomato. (SPECIALTY, see page 3.) "John Baer" Tomato produces perfect, solid, high crown, beautiful brilliant red shipping Tomatoes in thirty days from strong plants grown in veneer bands or from potted plants if the roots are undisturbed when set out. Pkt. 5 and 10 cts.; oz. 70 cts.; I/4 Ib. $\$ 2.25$; lb. $\$ 8.00$.

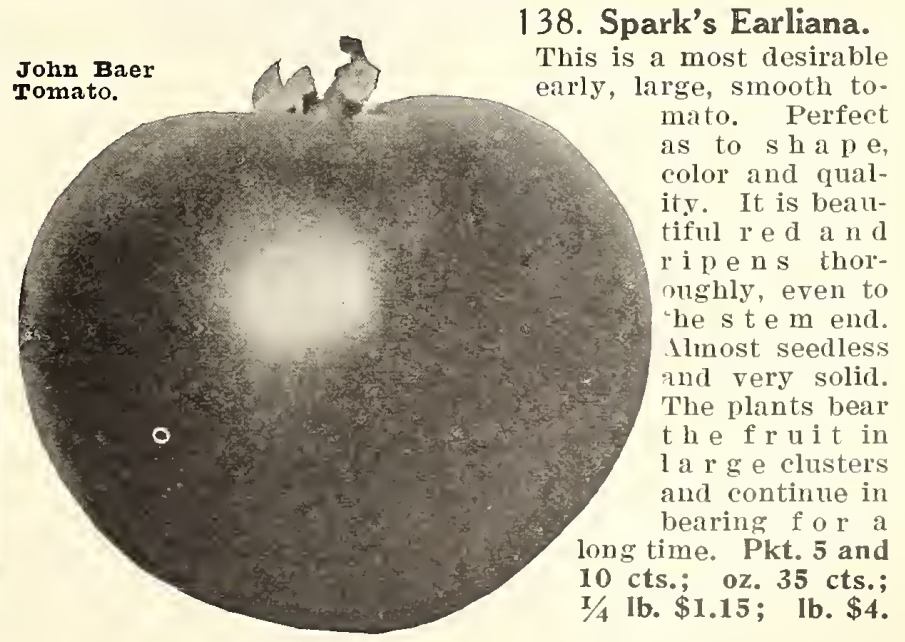




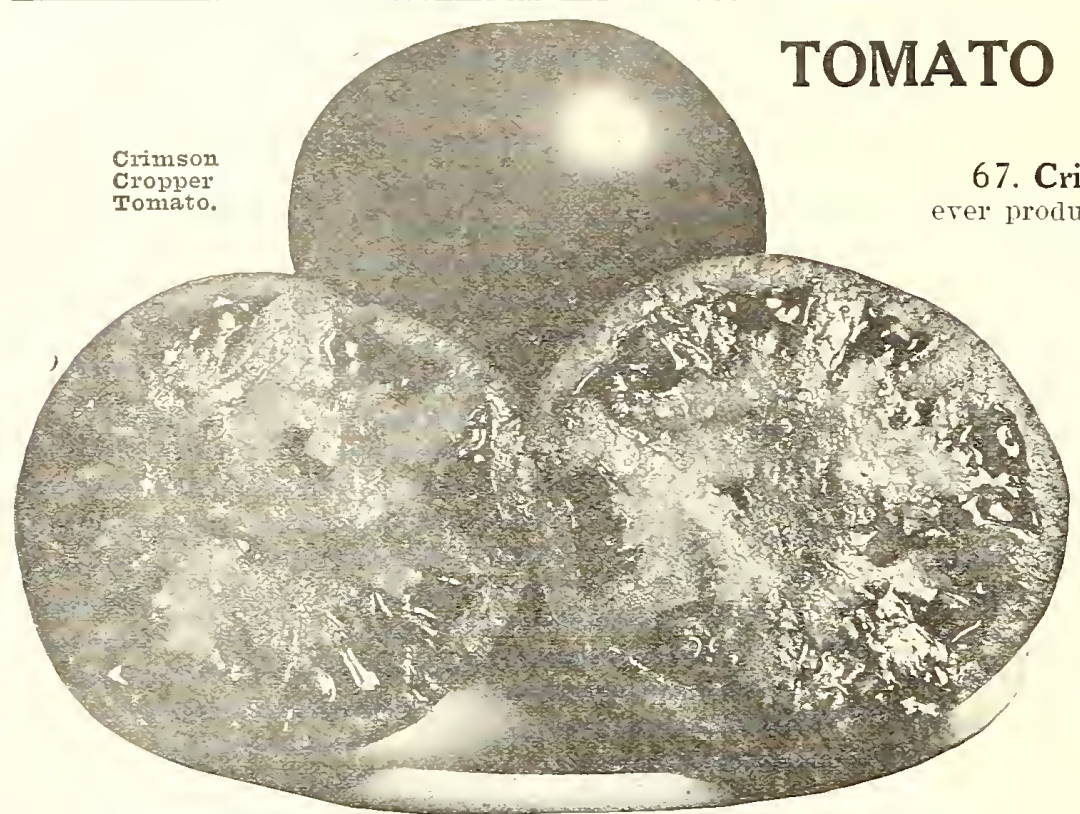

\section{Red Tomatoes}

Prosperity. The Wonder among new early tomatoes. The earliest of all tomatoes, a brilliant red. an enormons sielder. Grown and dereloped from single plant, selections covering a period of fire rears. filled full of strong. sturds. healthy, new blood. Pkt. 5 and $10 \mathrm{cts}$; $0 z .45 \mathrm{cts}$; $1 / 4 \mathrm{lb}$. $\$ 1.35 ; \quad$ lb. $\$ 5.00$.

Trophy. Tery large, solid, extra selected; free from roughness of the old strains. Pkt. 5 and 10 cts.; oz. 35 cts.; $x / 4$ lb. $\$ 1.15 ;$ lb. $\$ 4.00$.

217. Chalk's Early Jewel. One of the best early rarieties with vigorous rines producing many deep scarlet, smooth fruits of large size and excellent quality. They ripen early and the pickings continue through a long season. One of the best second early sorts, and on account of its large size, splendid quality and productireness, very satisfactory for the home garden. Pkt. 5 and 10 cts.; oz. 35 cts.; $\quad \mathrm{T} / 4$ lb. $\$ 1.15 ;$ lb. $\$ 4.00$.

My Maryland. A wonderful "Double Yielding" Tomato. entirely distinct. Nerer before has there been a regetable so remarkable. It is simple startling in its immense püuductireness. Pkr. 5 and $10 \mathrm{cts}$; $0 z .50 \mathrm{cts}$.; I/4 lb. $\$ 1.65$ lb. $\$ 6.00$.

C17. Livingston's Favorite. As the name implies, this rariety has long been a farorite with canners and the home trade. Farorite is one of the best shaped. large, bright red tomatoes. The fruit ripens erentr, is almars smooth and holds its size to the end of the season. Flesn is of good flaror and rerr solid. Pkt. 5 and 10 cts.; oz. 35 cts.; $x / 4$ lb. $\$ 1.15 ;$ ib. $\$ 4.00$.

King of the Earlies Tomato. Large and productive: rert early. Pkt. 5 and 10 cts.; oz. 40 cts.; I/4 lb. $\$ 1.25$; Ib. $\$ 4.50$.

Livingston's Paragon. Bright red, round: rery proluctive. Pkt. 5 and 10 cts.; 0z. 35 cts.; 1/4 lb. $\$ 1.15$; lb. $\$ 4.00$.

8. Matchless. Flesh verp solid, deep red eolor: uniform size. Pkt. 5 and 10 cts.; oz. 35 cts.; $1 / 4$ lb. $\$ 1.15 ;$ lb. $\$ 4$.

Great Falls, s. C.. April 25. 1921.

F. TI. BOLGIANO \& CO.

Washington. D. C.

Gentlemen,-Please send me two large packages of rour Red Cross Tomato Seed. I sure do like rour Red Cross Tomato. I think it is the finest of all.

Fours respectully, MRS. R. E. BOWERS. cts.; T/4 1b. $\$ 1.15 ;$ lb. $\$ 4.00$.

72. Bolgiano's "Greater Baltimore." This tomato is the greatest success in growing tomatoes in late 5 ears. It is better than the "Stone" erer" was. It has double the rield of many of the best cropping tomatoes you have ever grown. smooth, Well formed and deep from stem to blossom. Tert hears, dne to its extreme firmness and great meatiness. Ripens evenly to the rerr stem: free from ridges and cracks. Fruit is large and grows in clusters. Vine sturdy in growth. Brilliant red color: the handsomest fruit possible to get. It matures as a main crop tomato. and continues to bear through the season. Pkt. 5 and 10 cts.; oz. 45 cts.; 1/4 lb. $\$ 1.35 ; 1$ lb. $\$ 5.00$.

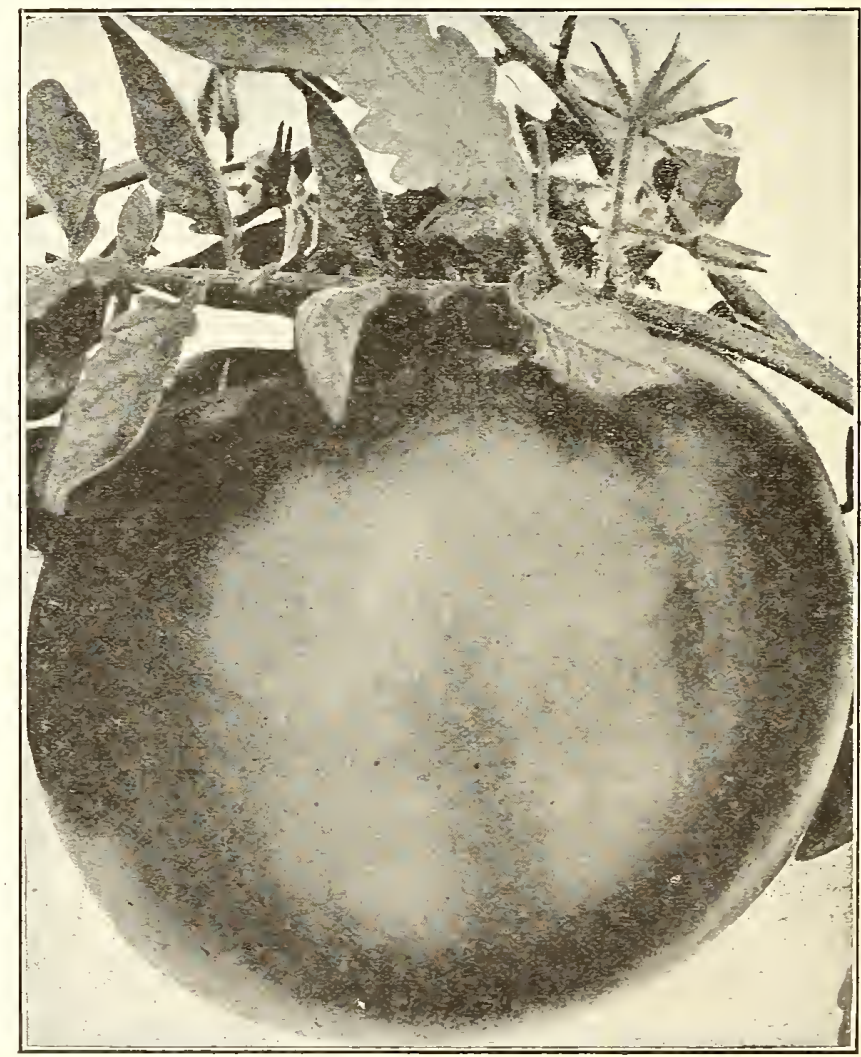

Greater Baltimore Tomato. 


\section{TOMATO}

\section{Red Tomatoes}

Bolgiano's "Florida Special" Tomato. Not a single grower of Tomatoes in Florida or in any locality where blight has injured the tomato crops, should go through this season without trying this most excellent new tomato. We call it "Florida Special," for it has been most carefully bred up to resist the ravages of bliwht which has been so discourla ging to o $13 \mathrm{r}^{\circ}$ Florida customers. It is red in color, large in size, fine flat vored, firm and meaty, very prolific, a n d about as early as the Larliana a nd a mos t excellent shipper. Pkt. 5 and 10 cts.; $0 z$. 40 cts.; $1 / 4$ lb. $\$ 1.25 ; 1 b . \$ 4.50$.

\section{Kelly Red, or} Wade Tomato.

This splendid Red To m ato originated in Anne Arundel County, MId., and mrough its superior qualities it has become the tomato most largely used in that section. It is large, meaty, and an abundant yielder, and withstands unfavorable conditions remarkably well. Pkt. 5 and 10 cts.; $0 z .35$ cts.; $x / 4$ lb. $\$ 1.15 ; 1 b . \$ 4.00$.

141. Bolgiano's Best, The Great B. B. It has every good quality pertaining to the Tomato, and avoids all faults of other sorts. One of the smoothest, most solid, heaviest and most handsome tomatoes grown. The B. B. is as solid as an apple, has no core, and the flavor is excellent. It weighs more pounds per bushel than other sorts, which proves its solidity; it has a beautiful red color: the fruits are quite large. Used successfully for early and late crops. Pkt. 5 and 10 cts.; oz. 35 cts.; 1/4 lb. \$1.15; lb.\$4.00.

136. New Century Tomato. The size, sield and productiveness of this tomato is beyond question a mark that has few equals in tomatoes. It will carry for two weeks without harming its red beauty or eracking. It maintains its wonderfnl size during the entire season. Pkt. 5 and 10 cts.; oz. 35 cts.; 1/4 lb. $\$ 1.15 ;$ lb. $\$ 4.00$.

222. Red Rock. One of the standard varieties of average to late season. It is one of the best croppers, producing many fruit of even size. It is remarkably smooth and has a splendid texture. Pkt. 5 and 10 cts.; 0z. 35 cts.; $1 / 4 \mathrm{lb}$. $\$ 1.15 ;$ lb. $\$ 4.00$.

\section{Pink Tomatoes}

44. June Pink Tomato. The pleasing color, with its splendid large size and firmness, is all that can be expected. We get our seed each season from the originator, knowing as we do that he who introduced it will take best care to see that his seed is as nearly perfeet as possible. Pkt. 5 and 10 cts.; oz. 35 cts.; 1/4 lb. $\$ 1.15 ;$ id. $\$ 4.00$.

28. Livingston's Globe. We can hardly speak too well for this tomato; introduced in Ohio, it has gradually increased in demand until now it is one of the leaders. Large, purplish-pink, solid; comes immediately after the earliest sorts. Enormously produetive. Pkt. 5 and 10 cts.; oz. 45. cts.; $x / 4 \mathrm{lb} . \$ 1.35 ;$ lb. $\$ 5.00$.
47. Bolgiano's Grand.

hitro taken as well as this Gew introdnctions of late years finit a standard main crop tomato. The lange, smooth, pink finit inakes it the finest tomato that has come to the Washington market the past three seasons. We are sure that wherever it has once been used it will be used again. Pkt. 5 and 10 cts.; oz. 40 cts.; 1/4 lb. $\$ 1.25 ; \quad$ th. $\$ 4.50$.

90. Bolgiano's Prize-Taker. Its beautiful, glossy purylish-pink color, combined with its large size, smoothness, solidity, weight and productiveness, make it the most profitable tomato grown by the market gurdener. It can be picked before it is ripe, and will ripen finely, making it one of the best shippers. Pkt. 5 and 10 cts.; 0z. 35 cts.; 1/4 lb. $\$ 1.15 ;$ lb. $\$ 4.00$.

52. Livingston's Beauty. Fine, large, purplish pink, Pkt. 5 and 10 cts.; 0z. 35 cts.; $1 / 4 \mathrm{lb} . \$ 1.15 ; \mathrm{lb}$. $\$ 4.00$.

C24. Ponderosa. Largest tomato that grows; a de (idedly family favorite; less acid than others. Pkt. 5 and 10 cts.; oz. 45 cts.; 1// lb. $\$ 1.35 ;$ lb. $\$ 5.00$.

\section{C22. Trucker's Favorite.} free from erack or rot Pkt. 5 and large, purple tomato, $1 / 4$ lb. $\$ 1.15 ;$ lb. $\$ 4.00$.

151. Acme. Very early; good size; purple in color; good bearer. Pkt. 5 and 10 cts.; 0z. 35 cts.; I/4 lb. \$1.15; Ib. $\$ 4.00$.

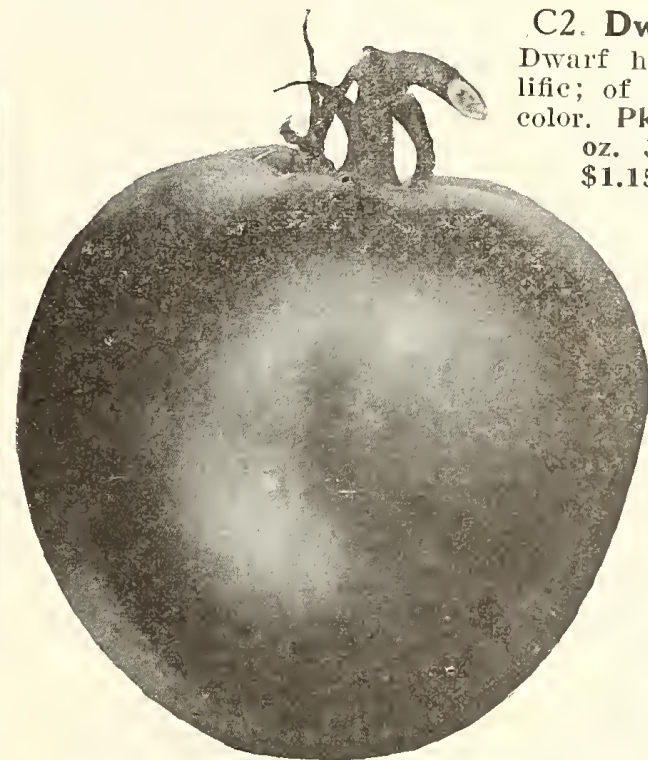

C2. Dwarf Champion. Dwarf habit, early, proific; of a pink - purplish Pkt. 5 and 10 cts.; $\$ 1.15 ;$ ib. $\$ 4.00$.

New Splendid. A good second e a r l y tomato While not quite as early as the June Pink, yet it li a $s$ good character a $\mathrm{n} d$ is $\mathrm{pr}^{\circ}$ o ductive. The $\mathrm{fru}$ it is large and continues to bear well for a long t i m e. Pkt. 5 and $10 \mathrm{cts.}$; oz. $45 \mathrm{cts}$; $\mathrm{x} / 4 \mathrm{lb}$. $\$ 1.35 ; 1 \mathrm{lb}, \$ 5$.

Improved Iivingsion's Globe Tomato.

\section{Yellow Tomatoes}

C10. Golden Queen. Large, solid, bright yellow; farorite with home gardeners; delicious flavor. Pkt. 5 and 10 cts.; oz. 35 cts.; $1 / 4$ lb. $\$ 1.15 ;$ lb. $\$ 4.00$.

C3. Pear-Shaped Yellow. Bright yellow, used for preserves. Pkt. 5 and 10 cts.; oz. 35 cts.; $x / 4$ lb. \$1.15; Ib. $\$ 4.00$.

C35. Plum-Shaped Yellow. Bright yellow, used for preserves. Pkt. 5 and 10 cts.; oz. 35 cts.; 1/4 lb. \$1.15; lb. $\$ 4.00$.

207. Red Cherry. Iittle fruits; bright red. Pkt. 5 and 10 cts.; oz, 40 cts.; $x / 4 \mathrm{lb}$. \$1.15. 


\section{Oz. for 200 Feet Drill.}

\section{TURNIPS}

2 Ibs. for the Acre.

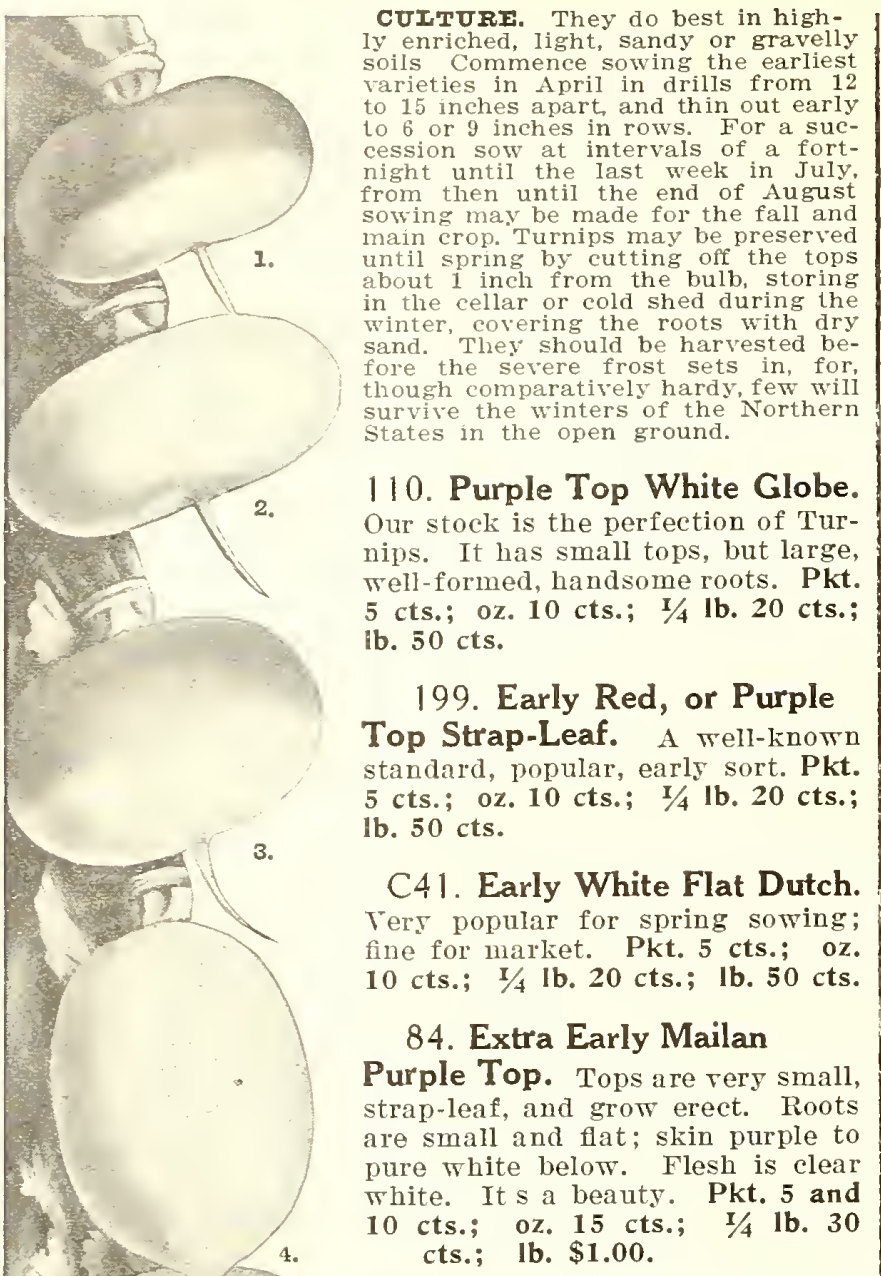

C18. Extra Early White

Milan. Pkt. 5 and 10 cts.; oz. 15 cts.; $1 / 4$ lb. 30 cts.; lb. $\$ 1.00$.

\section{White Egg. Is very} handsome; pure white; excellent for early or late. Pkt. 5 and 10 cts.; oz. 15 cts.; $1 / 4$ lb. 20 cts.; lb. $60 \mathrm{cts}$.

\section{C16. Golden Ball, or}

Orange Jelly. $\mathrm{o}$ e of $t \mathrm{~h}$ e sweetest flesh yellow Turnips yet introduced; not of large size, but firm, hard, and of excellent flavor; good keeper and superior table variety; of bright golden orange color. Pkt. 5 cts.; oz. 10 cts.; $1 / 4$ lb. 20 cts.; lb. 50 cts.

1. EarIy Milan Parple Top.

2. Early white Flat Dutch.

3. Purple Top Strap Ieaf.

4. White Fgg.

. Golden Ball

Purple Top White Globe. Globe. Tigorous grower; fine keeper. A rery desirable variety, attaining large size. The roots are rather oral-shaped, Iflesh orange-yellow. Pkt. 5 cts.; 0z. 10 cts.; r/4 lb. 20 cts.; lb. 50 cts.
139. Yellow Aberdeen. Fine for table or cattle. Pkt. 5 cts.; oz. 10 cts.; I/4 lb. 20 cts.; lb. $50 \mathrm{cts}$.

C15. Seven Top. Very hardy: grown for leares, which are used for salads. Pkt. 5 cts.; oz. 10 cts.; 1/4 lb. $20 \mathrm{cts}$; lb. 50 cts.

Southern Prize, or Dixie. Makes large, round, white Turnips in addition to salad: hardy and needs no protection, the most popular winter and spring salad grown. Pkt. 5 cts.; 0z. $10 \mathrm{cts}$.; $1 / 4$ lb. $20 \mathrm{cts}$; lb. $60 \mathrm{cts}$.

Ruta Baga, Long Island Special. This selection produces little or almost no neck at all, making it an ideal for the trucker. Excellent rariety for table use. Flesh golden; very sweet, not the least bit stringy or tough. Far superior to any of the other varieties, and much nicer than the Swede Turnip. Solid and crisp until spring. Nerer gets pethy. Pkt. 5 and 10 cts.; $0 z .15$ cts.; $1 / 4$ lb. 25 cts.; lb. 75 cts.

148. Improved Purple Top Yellow Ruta-Baga. Finely bred strain. Pkt. 5 cts.; oz. 10 cts.; 1/4 lb. 20 cts.; Ib. $50 \mathrm{cts}$.

C19. Long Cow Horn, or White French. A heary cropper, best for stockmen. Pkt. 5 and 10 cts.; oz. 15 cts.; I/4 lb. 25 cts.; lb. 75 cts.

Large White Norfolk. It is allowed to stand out during the winter in the South. Pkt. 5 cts.; oz. 10 cts.; 1/4 lb. 20 cts.; lb. $60 \mathrm{cts}$.

Pomeranian White Globe. Good either for table or stock; very productive. Pkt. 5 cts.; oz. 10 cts.; I/4 lb. 20 cts.; lb. 60 cts.

\section{HERBS}

All gardens should have some space deroted to the more important Pot Herbs. A few varieties are grown solely for the seed produced, which is used for flavoring cakes, bread, confectionery, etc. The young stems and leares of the plants used for flavoring may be gathered in the green state, or in the fall the entire plant may be pulled up and carefully placed in a dry room, and thus assure a winter's supply.

163. ANISE. Seeds used for flaror.

$$
\text { Pkt. Oz. } 1 / 4 \text { lb. Lb. }
$$

5. B A S I L SWEET. Culinary herb u s ed for flavoring soups, etc...........5c \& 10 c 30c 85c 3.00

164. CARAWAY. Cultirated for its seeds ..............5c \& 10c 15c 40c 1.50

16. CATNIP. Leares are used for seasoning ...........5 \& 10c 30c 85c 3.00

165. CORIANDER. Seeds are used for flavoring.........5c \& $10 \mathrm{c} \quad 15 \mathrm{c} \quad 40 \mathrm{c} \quad \mathbf{1 . 5 0}$

13. DILL. Mammoth. For sowing. Seeds u s ed for flaroring rinegar ............5 \& 10c 15c 40c 1.50

16. FENNELL FLORENCE. Grown for the enlarged leaf stalks ............. $\mathrm{c}$ \& $10 \mathrm{c} \quad 25 \mathrm{c} \quad 85 \mathrm{c} \quad 3.00$

16. FENNELL SWEET. Leares used in sauces.........5 \& $\& 10 \mathrm{c} \quad 25 \mathrm{c} \quad 85 \mathrm{c} \quad 3.00$

30. LAVENDER. True. For oil

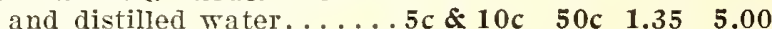

9. MARJORAM. Sweet. Is used for seasoning.........5 $\mathrm{c} \& 10 \mathrm{c} \quad 50 \mathrm{c} \quad \mathbf{1 . 3 5} \quad \mathbf{5 . 0 0}$
31. SAGE. Broad=leaf. A culinary herb; also used in medicine.5c \& $10 \mathrm{c} \quad 50 \mathrm{c} \quad 1.35 \quad 5.00$

19. SUMMER SAVORY ......5c \& $10 \mathrm{c} \quad 25 \mathrm{c} \quad 85 \mathrm{c} \quad 3.00$

18. THYME. Broad-leared English. Is used as a seasoning...............5 \& 10 c 50c $1.35 \quad 5.00$ 


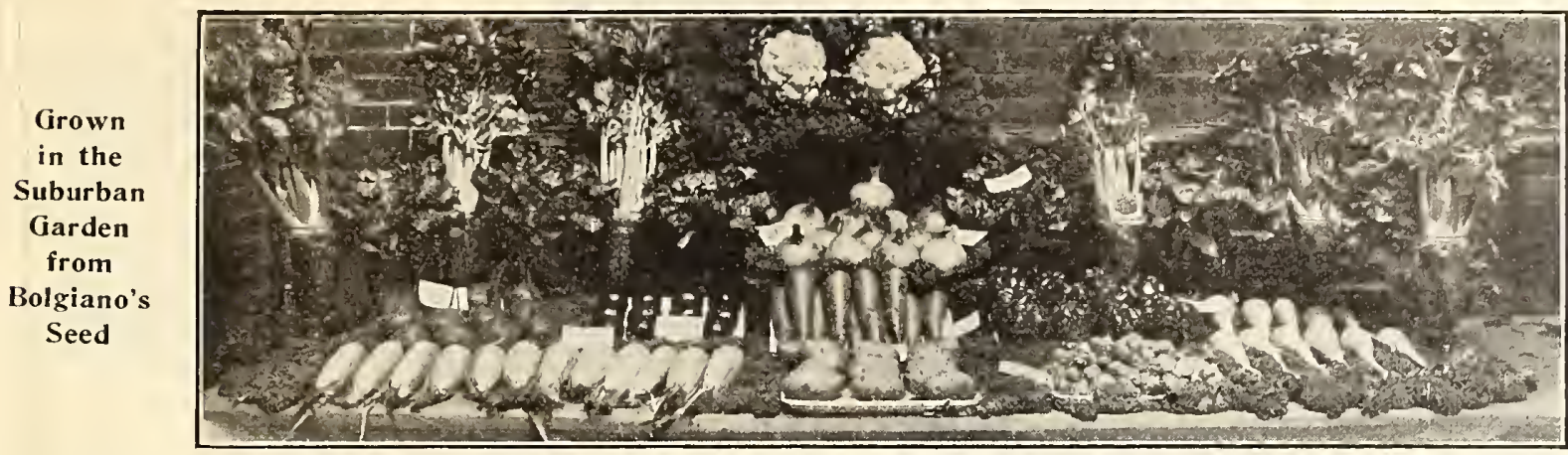

Grown

in the

Suburban

Garden

from

Bolgiano's

Seed

\section{Bolgiano's Small Back Yard Garden Collection}

It is surprising to know the large quantity of vegetables you can grow in your back yard. Spend your spare moments growing your own delicious vegetables. They are better than money can buy.

1 oz. Bolgiano's Superb Beet

1 pkt. Swiss Chard White Ribbed $\ldots \ldots \ldots \ldots \ldots \ldots \ldots \ldots \ldots \ldots$

1 pkt. Big Boston Lettuce $\ldots$

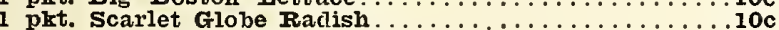

1 pkt. Green Mountain Parsley.......................

1 pkt. New Spring spinach.................

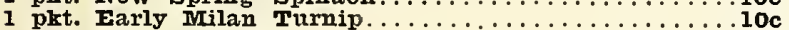

1 pkt. Capitol Tomato

1 pkt. Southport white Giobe onion..................

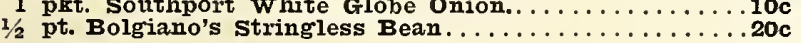

$\overline{\$ 1.25}$

Eleven different varieties cost buying separately $\$ 1.25$. We will mail this collection to your address for $\$ 1.00$, postpaid.

\section{Bolgiano's Suburban Garden Collection}

If you have a suburban home, a garden will profit you, alvays supplying plenty of fine fresh vegetables. Nothing will add to health more than working each day in your own garden -takes all the business cares away and rests the mind. Say. it is real manual exercise. It is a treat to have a garden.

1 pt. Bolgiano's Stringless Bean..............30c

1 pt. Bolgiano's New Wax Bean .....................

1 pt. Bolgiano's Emerald Isle Pole Iima................

1 oz. Bolgiano's superb Beet.....................

1 oz. Detroit Dark Red Beet......................

1 oz. Detroiano's Extra Early Harvester corn $\ldots \ldots \ldots \ldots$ 15c

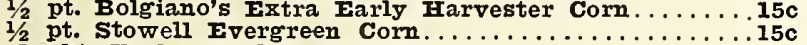

1 pkt. Farly scarlet Frorn Carrot...................

1 pkt. Danver Half Iong Carrot..................

1 pkt. All Fead Farly Cabbage................

1 pkt. Late Flat Dutch Cabbage...............

1 oz. Swiss

1 pkt. Brussell sprouts Paris Market..............

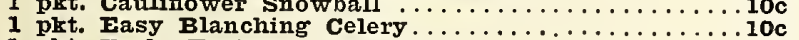

1 pkt. Farly Fortune Cucumber.....................

1 pkt. Snow Pickling Cucumber. $\ldots \ldots \ldots \ldots \ldots \ldots \ldots \ldots \ldots \ldots \ldots \ldots \ldots$

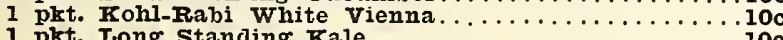

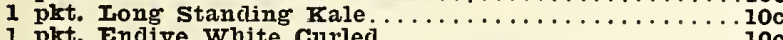

1 pkt. Endive white Curled..................

1 pkt. Big Boston Lettuce.................

1 pkt. Bolgiano's Masterpiece Lettuce.............

1 pkt. Prize Taker Onion ......................

1 pkt. Southport White Globe onion..................

1 pkt. Mustard ostrich Plume......................

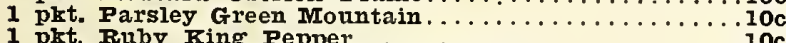

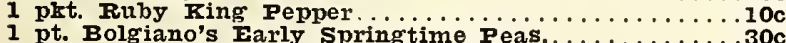

1 pt. Bolgiano's Early Bird Peas . Peas...........30c

1 pt. American Wonder Peas..........................

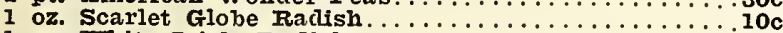

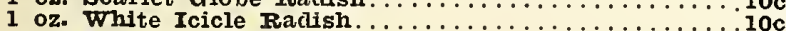

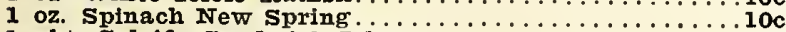

1 pkt. Salsify Sandwich Island..................

1 pkt. Farr's Benning Squash..................

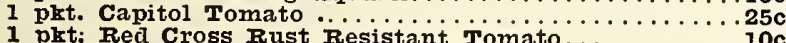

1 pkt. Early Milan Turnip

1 pkt. Purple Top White Globe Turnip.............

This is an ideal collection-39 varieties-plenty of seed to plant all during the season. We will mail this collection for $\$ 5.00$, postpaid. You save $10 \%$ ordering this way.

\section{Bolgiano's Country Garden Collection}

Many Country Gardens fail to grow the quantity and quality of vegetables they should, due often times to inferior seed.

We offer you in this collection all selected stocks that should please the most critical grower both in quality and yield.

1 qt. Bolgiano's Stringless Green Beans $35 \mathrm{c}$

qt Bolgiano's New Wax Beans.

1 qt. Bolgiano's Enormous Bush Lima

1 qt. Bolgiano's Emerala Isle Pole Lima.

1 pt. Kentucky Wonder Pole Beans

1 oz. Swiss chard Iucullus.

1 oz. Brussell sprouts Perfection.

1 oz. Bolgiano's Superb Beet

1 oz. Crosby Egyptian Beet.

1 oz. Detroit Dark Red Beet.

1 oz. New Farly Cabbage

1 oz. Late Flat Dutch Cabbage

1 pkt. Snowball Cauliflower.

1 pkt. Ox-Heart Carrot

1 pkt. Danver Half Long Orange Carrot.

1 pkt. French Golden Self-Blanching Celery

1 pkt. Easy Blanching Celery.

1 pt. Bolgiano's Extra Early Farvester Corn.......25c

1 pt. Stowell Evergreen Corn

1 oz. Early Fortune Cucumber

1 oz. Snow's Pickling Cucumber.

1 pkt. Black Beauty Egg Plant.

1 pkt. Endive White Curled.

1 pkt. Kale Long Standing.

1 oz. Big Boston Iettuce

1 oz. Bolgiano's Masterpiece Lettuce ..............50

1 oz. Bolgiano's Sweet Air Cantaloupe.......... 25c

1 pkt. Kleckley Sweet watermelon ...............

1 pkt. General Pershing watermelon ..................

1 oz. Prizetaker Onion ........................

1 oz. White Silver Skin Onion. .........

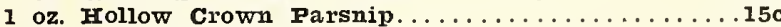

1 pkt. Parsley Green Mountain. ..................

1 pkt. Sweet MIountain Peppers ...............

1 qt. Bolgiano's Farly Springtime Peas ..........500

1 qt. Bolgiano's Early Bird Peas . . . . . . . . . . . 600

1 qt. American wonder Peas .................

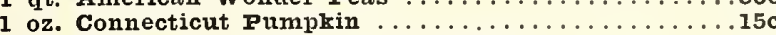

1 oz. Bolgiano's Scarlet Globe Radish..........15c

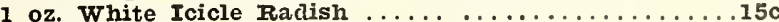

1 pkt. Salsify Sandwich Island ..............10c

$1 / 4$ lb. spinach Early spring ..........................

1 oz. Farr's Benning Squash $\ldots \ldots \ldots \ldots \ldots \ldots \ldots \ldots \ldots \ldots \ldots \ldots \ldots \ldots$

1 oz. Boston Marrow Squash ..................

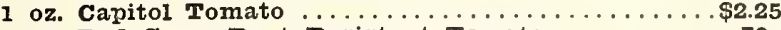

1 oz. Red Cross Rust Resistant Tomato..........70c

1 oz. Extra Early IMilan Turnip ..................

1 oz. Purple Top White Globe Turnip ...........10c

This wonderful collection of 47 different varieties produces continuous supply of good things all during the season-buying separately would cost you $\$ 12.80$. We will mail it to your address for $\$ \mathbf{1 0 . 0 0}$. You are really buying at wholesale prices in this way, delivered. 


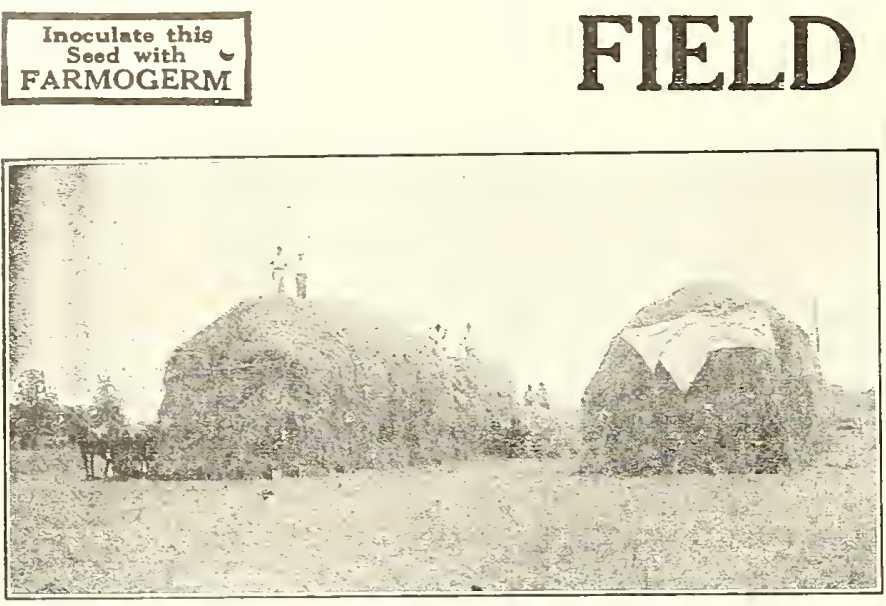

Bolgiano's Capitol Grass and Clover Seed.

Medium Red, or June (Trifolium pratense). This is reMarturage and hay. clover adds greatly to the fertility of the land on which it is grown. It does not exhaust the soil, but enriches it. It makes som for hay, The iast crop may be harvested for seed, cut for som for hay. The last crop may be harvested for seed, cut for particularly well adapted for sowing with Orchard grass and Timothy, as it ripens at the same time, and sowing these three grasses together will give larger yields and better quality hay than sowing either alone. It is also largely sown with other grasses, both for hay and pasturage. Sow in Spring or Fall, and if no other is required on old, stiff soils than on nev and lighter 5 1bs. $28 \mathrm{cts}$. per 1b.; 10 lbs. $26 \mathrm{cts}$. per 1b.; bus. \$14.40.

Mammoth, or Sapling (Trifolium pratense perenne). Is ance of seeds and habits of growth. the difference being larger growth and later maturing. It is often used for hog pastures. As a soil inmprover to plow under it is considered superior on account of its extra growth. It is a good variety for thin soils or to seed with Timothy, Mreadow Fescue, Herd's Grass or Red 10 to $12 \mathrm{lbs}$, to the acre when sown alone. When sown with acre. 5 lbs. 30 cts. per lb.; $10 \mathrm{lbs}$. $28 \mathrm{cts}$. per 1b.; bus. $\$ 15.00$.

Alsike, or Hybrid (Trifolium hybridum). Alsike Clover than Red Clover, making better hay and probably more and better grazing. It is also hardier, resisting extremes of heat and drought and also severely cold weather to a remarkable extent. It is perennial and does not Winter kill. It succeds on a valands. It will do better on moist land than any other Clover. It is surer to give a good stand and make good crops than either the Red or Mammoth Clover, and in sections where these Clovers have been uncertain Alsike is superseding them altogether. When sown with other grasses it forms a quick undergrowth and greatly increases the yield. Sow 8 pounds to the
27 cts. per 1b.; 10 lbs. 25 cts. per 1b.; bus. $\$ 13.80$.

Alfalfa, or Lucerene (Medicago sativa). Requires deep, root descends often to a depth of 10 to 15 feet in loose soil. It is, consequently, capable of resisting great droughts. It should be sown alone (about same time as oats are sown in this section) in thorougly prepared, deeply plowed soil, at the rate of 20 to 25 pounds to the acre. It may also be sown as late as
August and up to the middle of - September in more southerly localities. The crop should be cut when the plant is coming into bloom. In suitable soil it is perennial, and several crops may be cut every year. Height, 1 to
$10 \mathrm{lbs} .28 \mathrm{cts}$. per $1 \mathrm{~b}$; ; bus. $\$ 15.00$

Crimson, or Scarlet (Trifolium incarnatum). New Crop, best crop for hay, soiling and green manuring. Fall, Winter and Spring pasturing. Crimson Clover furnishes an abundance of nutritive forage at seasons when pastures are dead. It is an unfailing supply of manure. It solves the problem of cheap manuring. It is a great nitrogen gatherer and economizer in the use of fertilizers. Valuable for planting in orchards, berry patches and for sowing among cultivated crops, such as Cabbage, Corn, Tomatoes, Cotton, Tobacco. Improves poor land, restores to fertility those that have been worn down by excessive crop-
ping. May be planted in the Spring. Summer or Fall. Splendid
reseeding Red Clover that has been . Winter killed. Sow 15 lbs. to the acre. 5 lbs. 16 cts. per 1b.; 10 lbs. 14 cts. per 1b.; bus
SEEDS

Inoculate this

FARMOGERM

White Clover (Trifolium repens). Some White Clover is It makes an excellent turf that stands constant trampling. is of dwarf habit, spreads rapidly and is very hardy. It is valuis of dwarf habit, spreads rapidly and is very hardy. It is valu-
able in permanent patsures, being sweet and nutritious. Sow in able in permanent patsures, being sweet and nutritious. Sow in
Spring. In mixtures, 1 or 2 pounds; if alone, 8 or 10 pounds to the acre. 5 lbs. 60 cts. per 1b.; $101 \mathrm{lbs}$. 55 cts.

White Sweet Clover (Melilotus alba). Valuable sort of Grows from 3 to 5 feet high; sown in rich soil, may be cut three times; lasts for years if cut before flowering. Ten pounds to the acre. 5 lbs. 16 cts. per 1b.; 10 lbs. 14 cts. per $1 \mathrm{~b}$.

Timothy (Phleum pratense). The most valuable of all Thrives best on moist. loamy soils of medium tenacity. It should be cut just when the blossom falls. Sow early in the spring or fall, at the rate of 12 pounds per acre, with Clover Timothy, 6 lbs. Clover (either IIammotl Clover are Alsike Clover preferred, as they mature at the same time as Timothy), 6 lbs
Fancy Red Top, $1 / 2$ bushel Meadow Fescue. Together these will produce most excellent hay, also nutritious and abundant pasture
in good loany clay or low ground soils. 5 lbs. $12 \mathrm{cts}$. per $1 \mathrm{~b}$. in good loany elay or low ground
10 lbs. 10 cts. per 1b.; bus. \$3.50.

Red Top (Agrostis vulgaris). In Pennsylvania and States name applied in New England and New York to Timothy. It is good, permanent grass, standing our climate well, and makes good pasture when grazed close. Is valuable for low, wet meadows, producing a large return in good hay. When sown spring or fall, 5 lbs. 30 cts. per 1b.; 10 lbs. 28 cts. per lb. bus. \$7.50.

Orchard Grass (Dactylis glomerata). Desirable on acaftermath. It is ready for grazing in spring two weeks sooner than most grasses, and when fed off is again ready for grazing than most grasses, and when fed off is again ready for grazing in a week, and will continue green when other grasses are stock eat it greedily when green. A tendency to grow in tufts unfits it for lawns. It does better if sown with clover, and as it ripens at the same time, the mixed hay is of the best quality.
If sown alone, about 28 pounds are required per acre; if sown If sown alone, about 28 pounds are required per acre; if sown vears, 5 lbs. 25 cts. per 1b.; 10 ibs. 23 cts. per 1b.; bus. $\$ 3.00$.

Kentucky Blue Grass (Poa pratensis). This grass is not but makes the sweetest and most nutritious pasture for all kinds of stock. Kentucky has long been famous for its high bred horses and its Blue Grass pastures. It is now possible to establish on most any farm a Blue Grass pasture of greenest verdue which will give very profitable returns. This Grass is the first to start up in the Spring and remains green until snow flies in the Fall. It is very hardy and is uninjured by cold or dry weather, hot sun or tramping of hoofs. The roots are so thick and stout that they form a tough sod. Blue Grass requires ahout two years to get well started and for that reason it is almost any land, but does best on well drained clay land. Sow in the Fail or Spring at the rate of two or three bushels per

Tennessee Cultivated Golden Millet. This variety is throughout the United States, as they find it more nutritious in value for feeding. It is grown at the same time and at the same rate per acre as the common Mrillet Growers once using the Tennessee Cultivated Millet will never plant any other kind. Grows more vigorous, gives a much larger yield of hay. 5 lbs.
$10 \mathrm{cts}$. per $1 \mathrm{~b}$.; $10 \mathrm{lbs} .8 \mathrm{cts}$. per 1b.; bus. $\$ 2.50$.

Perennial Rye Grass (Lolium perenne). A very valuable ceeds well on almost any soil, but is particularly adapted to moderately moist or irrigated lands. Sow 30 to 40 pounds per
acre in spring. 5 lbs. 15 cts. per 1 b.; 10 1bs. 12 cts. per lb.

Sudan Grass. It is a tall annual Grass reaching a height allowed to mature for 7 to 9 feet when planted in rows and bloom for hay, about 4 feet. The results have been so satisfactory that it is now established one of our permanent forage crops. It is easily cured and handled as hay crop. Stock of all kinds eat it readily and will leave any other hay for it. The food value is second only to Alfalfa. Should not be planted until the soil becomes warm in the Spring. Two to four cuttings per year can be obtained when sown broadcast for hay; the number of cuttings secured depends upon the length of the season and the moisture. The first crop will mature in from 50 to 60 days, and the second crop is ready for harvesting in from 20 to 30 days. Three tons of cured hay per cutting per acre has been secured and three cuttings made. It is a great drought resister and is particularly adapted to semi-arid regions. It is an annual and must be seeded each Spring. When seeded in rows 18 to 20 per acre. 5 lbs. 12 cts. per $1 \mathrm{~b}$; $10 \mathrm{lbs}$. 10 cts. per $1 \mathrm{~b}$. 


\section{FIELD SEEDS--Continued}

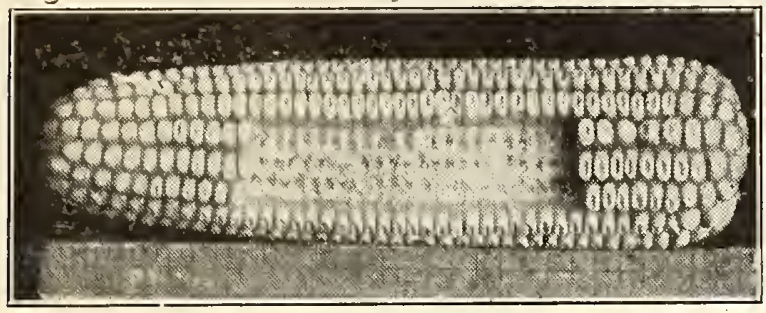

Bolgiano's Prosperity Yellow Corn.

\section{YELLOW CORN}

Bolgiano's Prosperity Corn. If you really want to growYellow Dent Corn this year, just take our advice and plant Bol. giano's "Prosperity" Corn. The fine, large, stately ears are 12 to 14 inches long, 8 to 11 inches in circumference and have from 20 to 24 uniforn rows of long, large kernels, well developed over tip and butt. It is a luxuriant grower, from 12 to 15 feet high, and if planted during the first half of May, will matur before the $20 \mathrm{th}$ of september. For more than a score of years "Prosperity Corn" has been under the most watchful breeding and selection. Peck, 85 cts.; bushel, $\$ 3.00$.

Reid's Yellow Dent. This is a splendid Yellow Dent vaon an ear. The cob is small and red and the grains are very close together, so there is scarcely any room between the rows. Reid's Yellow Dent has been awarded more prizes at Corn shows than any other variety except "Prosperity." The ears average

Improved Leaming Corn. Its extreme earliness and fine opular with the farmers, and especially with those in the localities where the seasons are short. It produces from 65 to 90 bushels to the acre, in accordance with the quality of the soil. The ears and grains are of medium size. Pk. 75 cts.; bus. $\$ 2.50$.

Mammoth Golden Beauty Corn. Has the largest ears It outyields many other corns. The increased yields repay the seeds many times over. Growers should make sure of getting the largest yield and most handsome grain to meet competition and secure the highest prices. Ears usually average from 9 to 12 inches long and from 20 to 30 rows on the cob, some of th
stalks bearing from 2 to 3 ears. Peck, 75 cts.; bushel, $\mathbf{2 . 5 0}$.

\section{WHITE CORN}

Boone County White (Pedigreed Stock). A nure whitc white cob. Very deep grain, not overly wide. Rows generally 20 , sometimes 22 to 24 . A perfect shape. That is the striking thin about it-big, long ears, beautiful shape,, perfect butts and tips, and deep grains. We believe this to be the best all-around thips, Corn in existence. It is a heavy yielder; has small cob and pro duces good-sized fodder, free from barren stalks. Matures in 110 days. Peck, 75 cts.; bushel, $\$ 2.50$.

"Hickory King" White Corn. So large are the grains on an ear broken in half a single grain will almost cover the col section. Of a strong growth, the stalks take a firm hold in thi ground and siand upright. It yields splendid crops on light soils, and is undoubtedly the best and most productive White Field Corn for the South. Peck, 75 cts.; bushel, $\$ 2.50$.

Eureka Ensilage Corn. The very best silo Corn on the used great care in the selection of our seed, which will give large amount of fodder 3 or 4 long, slender ears of Corn to the stalk. Grows to a height of 15 feet. Can'be sown in hills ol planted in checked rows. It is a very rapid grower and can bo grown throughout the United States with wonderful success. Growers should not miss planting this special variety of ours or their silo Corn. Peck, 75 cts.; bushel, \$2.50.

Choice White Dent. Long narrow grain; large fodder; The stalks grow 7 to 8 feet high and set the ears about 31 cob. 4 feet from the ground. Peck, 75 cts.; bushel, $\$ 2.50$.

Evergreen Broom Corn. Improved. An excellent valength, fine, straight and has a green appearance when ripe, and sells at the highest market price. Sow in drills 3 feet apart and thin out to 3 inches. Sow 5 pounds per acre. $10 \mathrm{lbs}$., $10 \mathrm{cts}$. per 1b.; 20 lbs., 9 cts. per 1b.; 50 lbs., 8 cts. jer lb.

White Kaffir Corn. Makes nutritious food for stock and years has been generally sown with Kaffir Corn in the last few rate of a peck of Kaffir Corn to a bushel of Cow Peas per acre $10 \mathrm{lbs}$., $10 \mathrm{cts}$. per 1b.; $20 \mathrm{lbs}$., 9 cts. per $1 \mathrm{~b}$.; $50 \mathrm{lbs}$., $8 \mathrm{cts}$. per lb.

\section{COW PEAS, SOJA BEANS AND FORAGE CROPS}

The Soil Improvers-Make Poor Iand Rich-A Splendid Hay Crop Whippoorwill Cow Peas. is casy to harvest. We sell more of this variety than any other,
and consider it the best for general purposes. Pk. 85 cts.; bus. $\$ 3$.

Black Cow Peas. 85 cts.; bushel, $\$ 3.50$.

Clay Peas. Sceds medium sized and cream colored. Vines Peck, 85 cts.; bushel, $\$ 3.00$.

Shinney Pea. Ver'y popular, seed large, mottled white and 85 cts.; bushel, $\$ 3.00$.

Mixed Cow Peas. We strongly recommend sowing Mixed The upright growing varieties holding up the vining varieties, they will make a much better growth and give more satisfactory lesults. Peck, 75 cts.; bushel, $\$ 2.75$.

Black Eye. Vines erect. Seeds mediun sized and white

Canada Field Peas. Here is a crop which is not only land the much needed nitrogen. Peas are second only to clover in theil soil enriching properties and can be grown under almost any condition of soil or climate. There is always a ready market for Peas, or they can be profitably ground and fed to the stock.
The vines make rich, nutritious hay. Peck, \$1.15; bushel, \$4.25.

Mammoth Yellow Soja. The largest growing and most purposes, although a little later in maturing than other varieties.

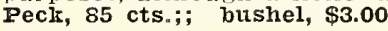

Tar-Heel or Mammoth Black Soja. Slightly e a r 1 i e r low and produces about same amount forage. Peck, 85c; bus. $\$ 3$.

Mammoth Brown Soja. Matures slightly earlier than the about one-third more forage. Peck, 85 cts.; bushel, $\$ 3.00$.

Wilson Black Soja. Very small seed, matures in about Northern States where an early variety is desired. Peck $\$ 1.00$; bushel, \$3.50.

Hairy Vetch (Vicia villosa). This is a very valuable try aro learning more of its great value farmers of this counvaluable as a winter cover crop to prevent leaching, and for forage and fertilizing purposes. It is an annual. It succeeds well on nearly all soils and thrives surprisingly on poor, light rought, heat and cold. It improves the soil, being a great nitrogen gatherer. The roots bear innumerable rodules or nitrogen-gathering bacteria. These take the nitrogen from the air and restore it to the soil, where it is so much needed. It belongs to the Pea family, but the vines are much longer and the foliage is more abundant. It may be sown either in the spring or fall with about half. a bushel of Rye or Oats for support. It grows rapidy and is particularly valuable in sections where clover does not thrive. In the North it reearly pasturing. Not only does it produce an enormous amount of very valuable feed, but it at the same time restores to the soil a great amount of fertility, which is so much needed., 50 to 60 pounds of seed required to the acre. 5 lbs.- 15 cts. per $1 b$.; $10 \mathrm{lbs}$., $14 \mathrm{cts}$. per 1b.; $100 \mathrm{lbs}$., $13 \mathrm{cts}$. per $1 \mathrm{~b}$.

Spring Vetches or Tares. Closely associated with Peas same purpose as Hairy Vetch, but must be planted in the spring wherever the winters are severe, as this variety is not so hardy as Hairy Vetch. Highly valuable for soiling or for green manuring. Sometimes grown with Oats for mowing and feeding to pounds of Vetch and 40 pounds of Oats. 5 lbs. $10 \mathrm{cts}$, per $1 \mathrm{~b}$.;

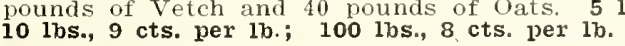

Dwarf Essex Rape. It is an annual, bearing a close reKale, but both leaves and stallss are more numerous in the Rape plant, and of a taller habit of growth. It is a pasture plant which may be eaten off by any kind of live stock, but it is swine. Under favorable conditions Rape is ready for pasturing sheep or cattle within six weeks from the time of sowing. 5 lbs., 15 cts. per lb.; 10 lbs., 14 cts. per $1 \mathrm{~b}$.; $100 \mathrm{lbs}$., $12 \mathrm{cts}$.' $1 \mathrm{~b}$. 


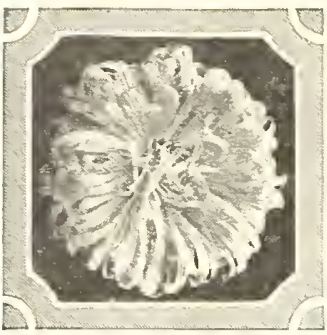

Five Cents a Paper.

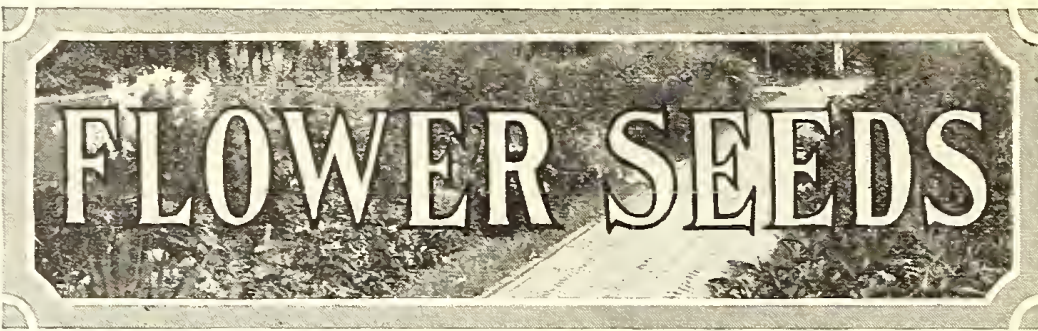

Tested and Reliable.

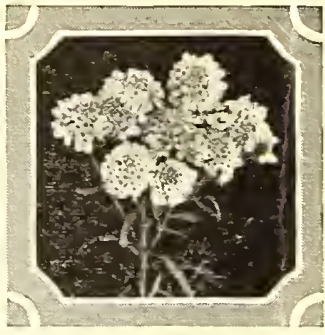

Postage Paid.
We are in position to offer to our trade Flower Seeds that have few equals and no superiors. Our selections have been made from the best American growers. The preparation of the soil is of vast importance with Flower Seeds, and provided there has been care taken in these respects we feel assured that our seed will give entire satisfaction. Much care must be used in sowing fine Flower Seed. so many times they are buried instead olanted. Most Flower seeds do best if sown in boxes and transplanted. Cale should always be taken not to plant too deep. and at the same time see that the soil may come in contact with the seed. It is well to cover the soll with moss or new grass to keep the soil moist and in condition until the germination of the seed is assuled, then remove the covering with care, and not during the sunny part of the day, but

\section{AMERICAN ASTERS}

Annuals. Attain full growth, flower and die in one year.

Biennials. Grow from seed one year, bloom and die tlue next. though some varieties bloom the first season when sown early.

Perennials. Last for several years, blooming annually after he first season, though some varieties will bloom the first seaon if sown early.

A-Signifies Amnual. B-Biennial. $\mathbf{P}$-Perennial.

ASTERS (A) are one of the most popular annuals and do well everywhere. Seed may either be planted early indoors or later in the open border. We suggest that sou include some of the named varieties in your order.

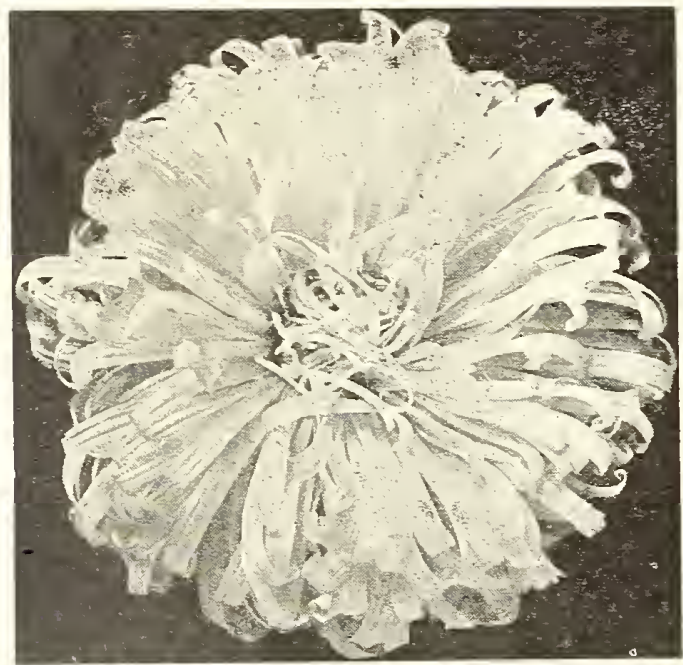

Featherbloom Asters.

\section{BOLGIANO'S FEATHERBLOOM ASTERS}

N56. FEATHERBLOOM WHITE. White flowers with petals resembling those of a Chrysanthemum. Pkt. 5 cts.; I/4 oz. 35 cts.; oz. $\$ 1.25$.

N9. FEATHERBLOOM PINK. Beautiful shell pink. Pkt. 5 cts.; $1 / 4$ oz. 35 cts.; oz. $\$ 1.25$.

36. FEATHERBLOOM LAVENDER. A beautiful pure lavender, fine form and size. Pkt. 5 cts.; 1/4 oz. 35 cts.; oz. $\$ 1.25$.

32. FEATHERBLOOM AZURE BLUE. A fine shade of vender blue. Pkt, 5 cts.; I/4 oz. 35 cts.; oz. \$1.25.
N4. FEATHERBLOOM PURPLE. Very rich in color. Pkt. 5 cts.; $1 / 4$ oz. 35 cts.; oz. \$1.25.

N2. FEATHERBLOOM MIXED. A mixture of many colors. Pkt. 5 cts.; $1 / 4$ oz. 30 cts.; oz. $\$ 1.00$.

\section{SEMPLE'S BRANCHING ASTERS}

N28. WHITE BRANCHING. Produces large, handsome double flowers on long stems. Pkt. 5 cts.; 1/4 oz. 30 cts.; oz. $\$ 1.00$.

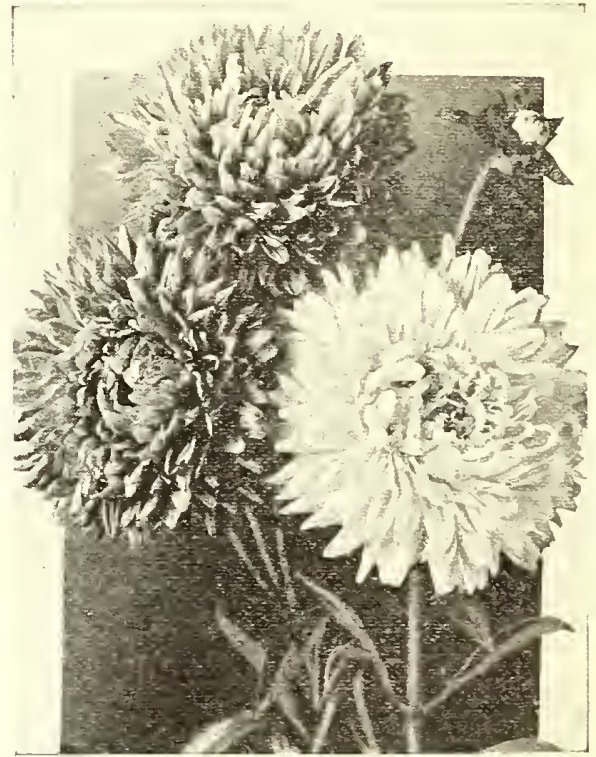

Semple's Branching Asters.

N53. PINK BRANCHING or MARY SEMPLE. Large double flower's of a beautiful shell-pink color. Pkt. 5 cts.: I/4 oz. 30 cts.; oz. $\$ 1.00$.

N6. CRIMSON BRANCHING. A bright showy crimson. Pkt. 5 cts.; $1 / 4$ oz. 30 cts.; oz. $\$ 1.00$.

N25. LAVENDER BRANCHING. Light lavender, large, double flowers. Pkt. 5 cts.; $1 / 4$ oz. 30 cts.; oz. $\$ 1.00$.

15. AZURE BLUE BRANCHING. True lavender approaching azure blue. Pkt. 5 cts.; $1 / 4$ oz. 30 cts.; oz. $\$ 1.00$.

N3. PURPLE BRANCHING. Double purple flowers. Pkt. 5 cts.; 1/4 oz. 30 cts.; oz. $\$ 1.00$.

99. BRANCHING MIXED. A mixture containing all colors; flowers produced on very long stems. Pkt. 5 cts.; 1/4 oz. 25 cts.; oz. 75 cts.

N1. QUEEN OF THE MARKET ASTERS, MIXED. The earliest aster, producing a profussion of fine blooms. Pkt. 5 cts.; 1/4 oz. 25 cts.; oz. 75 cts. 
28. AGERATUM, MEXICAN MIXED. A. Lavender-blue and pure white brush-like flowers borne in great profusion. Attains height of about two feet. Pkt. 5 cts.; $x / 4$ oz. 15 cts.; $0 \mathrm{z} .50$ cts.

30. ALYSSUM, LITTLE GEM. A. Dwarf spreading plants about four inches high and covered with a unass of white bloom. Pkt. 5 cts.; x/4 oz. 15 cts.; oz. 40 cts.

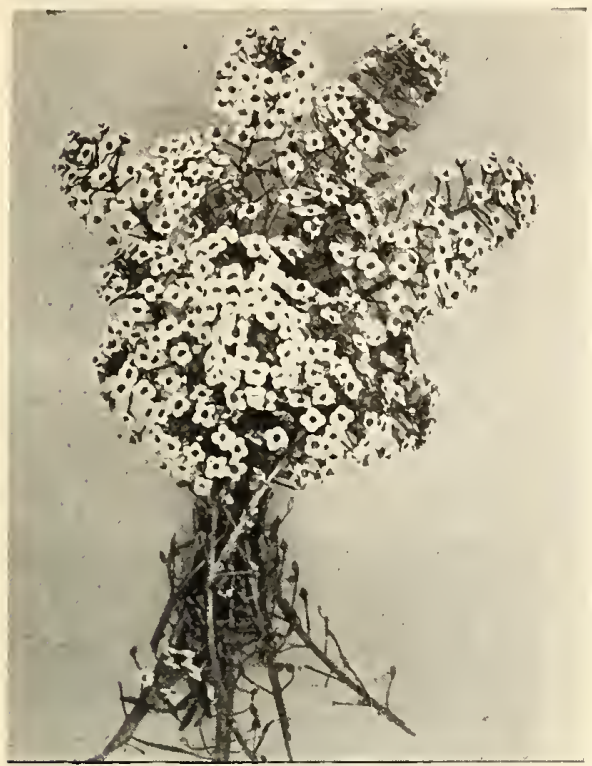

Sweet Alyssum.
19. AMARAN= THUS, TRICOLOR or JOSEPH'S COAT. A. A brilliant colored plant attaining a height of about th i t y inches. Pkt. 5 cts.; $\pi / 2$ oz. 20 cts.; oz. 30 cts.

42. ANTIRRHI= NUM, HAL F DWARF MIXED. A. Plants grow about two feet high and produce on long spikes flowers of large sizes and most attractive in coloring. Easily grown; fine for cutting. Pkt. 5 cts.; $\quad x / 4 \quad 0 z$. 25 cts.; oz. 75 cts.

N27. BACHELOR'S BUTTON (Centaurea Cyanus). A. These are also called "Blue Bottle." The flowers are of a distinct graceful beauty. All colors mixed. Pkt. 5 cts.; x/2 oz. 15 cts.; oz. 25 cts.

\section{BALLOON VINE. See page 50.}

N27. BACHELOR'S BUTTON (Centaurea Cyanus). A. A. These are the old "Lady Slipper," but vastly improved

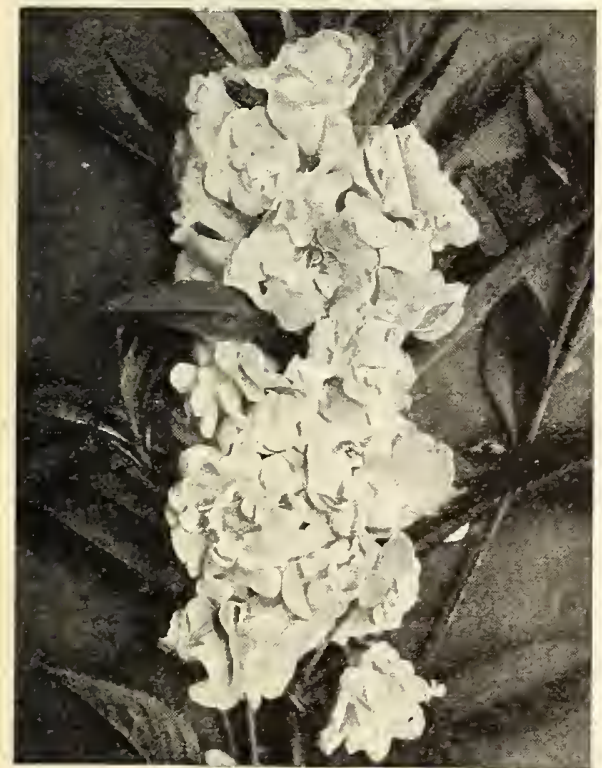

Balsam, Double Camellia-Flowered. as to doubleness of the beautiful flowel's. Pkt. 5 cts.; $\quad 1 / 4$ oz. 15 cts.; oz. 50 cts.

BALSM APPLE. See page 50 .

35. C A L E N= DULA DOUBLE MIXED. A. Does well in cool locations. Should be planted e ith e $\mathrm{r}$ $\mathrm{sing} \mathbf{\mathrm { y }}$ or in masses, Plants grow 12 inches $\mathrm{h}$ i g h , branch freely and flowe rs throughout the season. A fine mixture of $y \oplus 110 \mathrm{~W}$ a $\mathrm{nd}$ orange shades. Pkt. 5 cts.; oz. 15 cts.

N58. CALLIOPSIS MIXED. A. Most desirable for cutting. This mixture contains many varieties. Pkt. 5 cts.; t $/ 2$ oz. 20 cts.; oz. 30 cts.
45. CAMPANULA, SINGLE MIXED CANTERBURY BELLS. P. Of most atractive growth, and the second year produce abundantly the beatiful bell-flower's in many colors. Pkt. 5 cts.; $/ 4$ oz. 15 cts.

CANARY BIRD VINE. See page 50.

17. CANDYTUFF. A splendid mixture of all colors. Pkt. 5 cts.; 1/2 oz. 15 cts.; oz. 25 cts.

N5. CANDYTUFT, GIANT HYACINTH FLOWERED WHITE. A. Large, elongated head with pure florets. Desirable for cutting. Pkt. 5 cts.; $1 / 2$ oz. 20 cts.

N53. CANNA MIXED. P. A perennial plant if roots are lifted in the fall and carefully stored during the winter. Start the seed very early. Pkt. 5 cts.; oz. 25 cts.

13. CARNATION, MARGUERITE MIXED. P. Although a perennial, this should be treated as an annull, as from seed sown in the early spring the planter will have plants producing flowers toward the latter part of the summer. Pkt. 5 cts.; $1 / 4$ oz. 35 cts.; oz. $\$ 1.25$.

44. CHRYSANTHEMUM, ANNUAL VARIETIES MIXED. A. They are not to be confused with the large late flowering varieties grown by florists. Easily grown from s e e d, and the plants flower freely until killed by frost. Many colors mixed. Pkt. 5 cts.; oz. 25 cts.

N28. C I N E R A RIA, FINE MIXED. $P$. It is exclusively a hous e plant and succeeds best if the seed is sown during the summer. Pkt. 10 cts.

N8. C L A R K I A MIXED. A. Contains the choicest varieties of this easily grown annual. Pkt. 5 cts.; $x / 4$ oz. 15 cts.; oz. 50 cts. CLEMATIS. See p. 50

38. C O C K S C O M B DWARF MIXED. A. Showy dwarf growing plants bearing large velvety combs. If the combs are cut before frost they may be dried and used for winter decoration. Pkt. 5 cts.; $1 / 4$ oz. 25 cts.; oz. 90 cts.

\section{COSMOS, EARLY FLOWERING}

The longer blooming period given by their starting to bloom four to six weeks earlier is making this class of cosmos very popular. Height four to six feet.

N54. GIANT PINK. Pkt. 5 cts.; $1 / 4$ oz. 20 cts.; oz. 50 cts.

N51. GIANT RED. Pkt. 5 cts.; $1 / 4$ oz. 20 cts.; oz 50 cts.

N48. GIANT WHITE. Pkt. 5 cts.; $1 / 4$ oz. 20 cts.; oz. 50 cts.

1. GIAN'T MIXED. Pkt. 5 cts.; oz. $30 \mathrm{cts}$; $1 / 4 \mathrm{lb}$. $\$ 1.00$.

103. COSMOS, FINEST MIXED. A. If seed is sown during the spring it will produce a tall growing plants, which will flower freely from September to November. Pkt. 5 cts.; oz. 25 cts.; r/4 Ib. 75 cts.

10. COSMOS, DOUBLE MIXED. One of the finest introductions of late years. A true cosmos with a beautiful double crested center. Pkt. $10 \mathrm{cts}$; $1 / 4$ oz. 65 cts. 
7. COLUMIBINE MIXED (Aquilegia). P. If seed is sown during the summer the plants will come into bloom the following year. A fine assortment of colors. Pkt. 5 cts.; I/4 oz. 20 cts.; oz. 60 cts.

\section{COBEA SCANDENS. See page 50.}

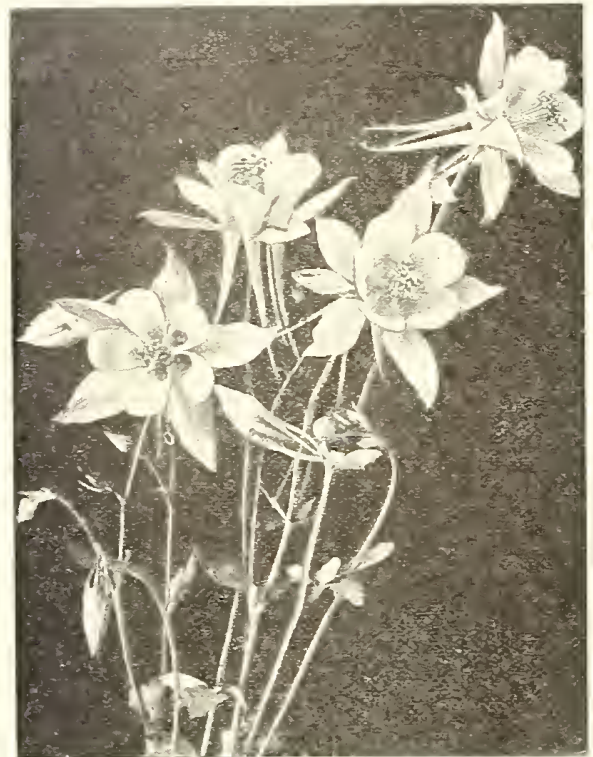

Columbine.
N10. CORE = OPSIS GRANDI= FLORA. P. During the summer be a r s profusc$1 y$ golden-sellow flowers which are rery useful for cutting. Pkt. 5 cts.; $\mathrm{t} / 2$ oz. 25 cts.; oz. 40 cts.

36. C Y C L A $=$ $M \mathrm{E} \mathrm{N}$, PERSI $=$ CUM MIXED. P. A free-flowering plant for growing in the house. seed should be sown early in the spring. The orchidl-like blooms range in color from white to crimson. Pkt. 10 cts.; $\quad \mathrm{I} / 4$ oz, 35 cts.; 0z. \$1.25.

C Y P R E S S VINES, See p. 50 .

101. DAHLIA, CHOICE DOUBLE MIXED. P. These grow very easily fiom seed, and flower freely the first season. and the roots may be kept over from year to rear. Pkt. 5 cts.; $1 / 4$ oz. 35 cts.; oz. \$1.25.

101. DAHLIA, CHOICE DOUBLE MIXED. P. These grow rery easily from seed, and flower freels the first season, and the roots may be kept over from year to year. Pkt. 5 cts.; $1 / 4$ oz. 35 cts.; 0z. \$1.25.

22. DAHLIA, CACTUS MIXED. A. A fine collection of varieties of the popular quilled dahlia rarieties. Pkt. 10 cts.; $\quad \mathrm{t} / 4$ oz. 50 cts.; oz. $\$ 1.75$.

N26. DAISY, DOUBLE MIXED (Bellis Perennis). P. The hardy plants thrive best in conl shady places: The attractive small wothle flowers appear very early in the summer. Pkt. 5 cts.; $=1 / 4$ oz. 65 cts.

100. DELPHINIUM, HARDY LARKSPUR. P. Brilliant blue with white eye, blooming in June. Pkt. 5 cts.; $\mathbf{Y} / 4 \mathbf{~ o z . ~}$ $25 \mathrm{cts}$.

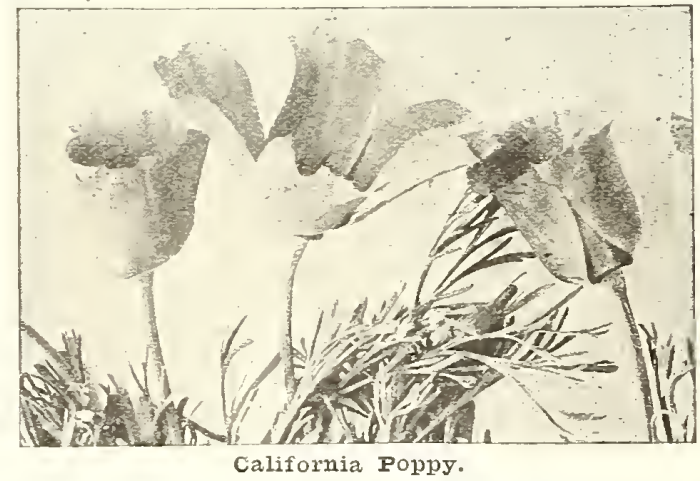

22. DIANTHUS or ANNUAL PINKS MIXED. A. The jlants grow one foot high and fower profusely during the ntire summer and fall months. The blooms are most deble for cutting. Pkt. 5 cts.; $1 / 4$ oz. 20 cts.; oz. 60 cts.
DIANTHUS PLUMARIUS. P. (Pheasant's Eye Pink). The original clore pink, of great beauty. Pkt. 5 cts.; 1/4 oz. 35 cts.; oz. \$1.25.

N22. ESCHSHCOLTZIA (California Poppy) MIXED. A. Plants of low spreading growth with cut feathery foliage and flowering during the entire summer. Pkt. 5 cts.; $1 / 4$ oz. 15 cts.; 0z. 25 cts.

44. FEVERFEW (Matricaria eximia fl. pl.). A. The plants attain a height of eight inches: dark cut leaf foliage: the pure white flowers are borne on long stems. Fine for cutting, Pkt. 5 cts.; $1 / 4$ oz. 30 cts.; oz. $\$ 1.00$.

5. FORGET=ME=NOTS (Myosotis Alpestris). P. Neat little plants with beautiful star-like blue flowers. It succeeds best in a moist, shady location. Pkt. 5 cts.; $1 / 4 \mathbf{~ o z}$. 25 cts.; oz. 85 cts.

S. FOUR O'CLOCK (Marvel of Peru) MIXED. A. The plants grow $21 \frac{1}{2}$ feet hich and are practically corered with the varied colored flowers about four $0^{\circ}$ clock in the afternoon. Pkt. 5 cts.; 0z. 25 cts.; 1/4 lb. 75 cts.

2. FOXGLOVE MIXED (Digitalis). P. Thè-alants grow three feet high and bear long spilies of thimble-shaped flowers of rarious colors. If planted in well-drained soi will thrive nicely. Pkt. 5 cts.; $1 / 4$ oz. 25 cts.; oz. 75 cts.

40. GAILLARDIA, A N N U A L VARIE= TIES $M$ I $X \quad E$. (Blanket Flowers). A. Glorius annual plants bearing gorge ous-colored flowers. Does exceed i $\mathrm{ng}$ ly well in hot, dry weather. Excellent for cutting. Pkt. 5 cts.; $\quad 1 / 4$ oz. $20 \mathrm{cts}$.; oz, 65 cts.

G A I L L A R DI A GRANDIFLORA. P. These perennial hy brids are worthy of a place in all hardy borders. The beautiful single flowers are red in the center with clear vellow markings on outer edges of petals. Pkt. 5 cts.; I $/ 4$ oz. 20 cts.; oz. $50 \mathrm{cts}$.

7. G E R N A I U $M$ ZONALE MIIXED. P. Although a peremnial, it is usually treated as annual $\mathrm{wh}$ e $\mathrm{n}$ grown from seed unless the plants are

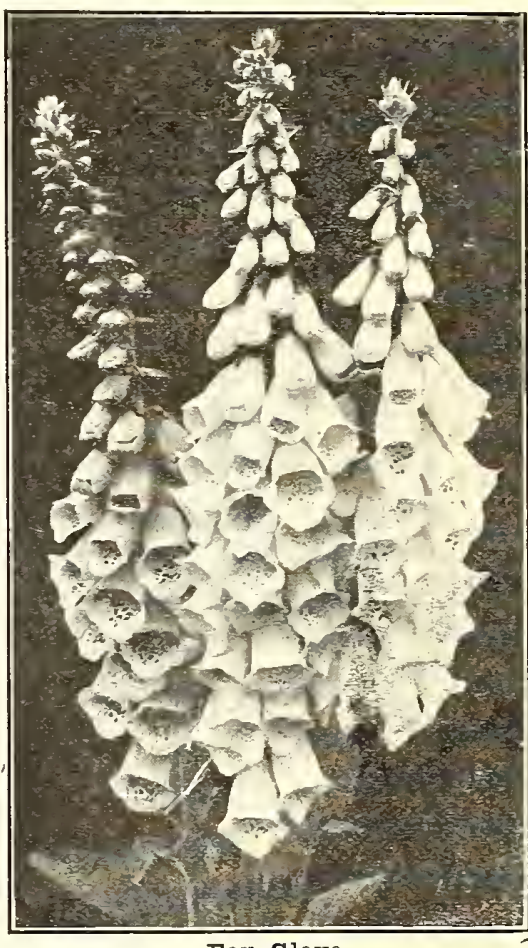

Fox Glove. taken indoors for the winter. Grows readily from seed planted indoors. Pkt. 10 cts.

N30. GILIA MIXED. A. Suitable plants for beds or rock eries. Free blooming and succeeds well in ans location. Pkt. 5 cts.; 1/4 oz. 15 cts.; oz. 35 cts.

9. GODETIA MIXED. A. Does best in cool locations. The plants bear freely attractirely shaped flowers, rich and varied in colors. Pkt. 5 cts.; $1 / 4$ oz. 20 cts.; oz. 50 cts.

GOURDS. See page 50 .

N19. HELICHRYSU M MIXED (Straw Flowers). A. This is really a double purpose flower. The plants during the late summer are most attractive with their beautiful double flowers which if picked before fully opened make fine dried blooms for winter decorations. All colors mixed. Pkt. 5 cts.; I/4 Oz. 15 cts.; oz. 50 cts. 


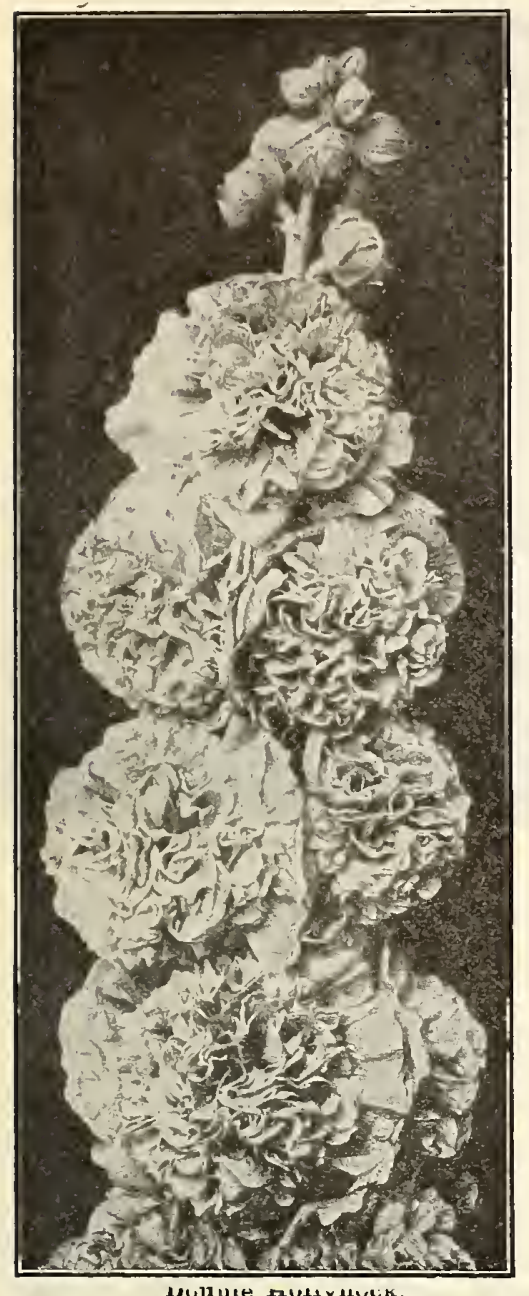

N11. HELIOTROPE, CHOICE MIXED. P. Rather tender and will not stand cold weather. Start seed indoors and do not set plants out-of-doors until all danger from frost is past. The flowers have a delightfully fragrant perfume. Pkt. 10 cts.; I $/ 4 \quad$ oz. 85 cts.; oz. $\$ 3.00$.

\section{N39. HIBRISCUS} MIXED (Mallow). P. Of late the Mallows have become very popular, and are worthy of a place in all beds of perennials. $\mathrm{T} h \mathrm{e}$ plants attain a height of from 4 to 6 feet and produce profusely the handsomest flowers from June until fall. Pkt. 5 cts.: $1 / 4$ oz. $20 \mathrm{cts}$.; oz. $75 \mathrm{cts}$.

29. HOLLYHOCK, C H O 1 C E DOUBLE MIXED. B. These are best treated as biennials. One of the most showy of all hardy garden plants. The majectic plants produce magnificent long spikes bearing beautiful d o u ble flowers which measure 3 to 4 inches across. Pkt. 10 cts.; $\mathrm{T} / 4$ oz. 35 cts.; oz. $\$ 1.15$.

N34. JOB'S TEARS. A. Curious ornamental grass with broad, cornlike leaves and lustrous slate colored seeds. Pkt. 5 cts.; $1 / 4$ oz. 10 cts.; oz. 25 cts.

N37. KOCHIA TRICHOPHYLLA. A. (Summer Cypress). A quick growing foliage or hedge plant very symmetrical in form and having innumerable tiny flowers in the fall when the bush takes on a red tinge. Pkt. 5 cts.; oz. 20 cts.

N39. LANTANA MIXED P. If to be treated as an annual start plants early indoors so as to insure a fine display of bloom during the summer. It makes a splendid house plant. Pkt. 5 cts.; $1 / 4$ oz. 15 cts.; oz. 50 cts.

41. LARKSPUR, ANNUAL VARIETIES MIXED, A. Very quick-growing and free-flowering. The varied colored flowers are produced on erect spikes. Will thrive anywhere. Pkt. 5 cts.; $1 / 4$ oz. 10 cts.; oz. 25 cts.

\section{HYACINTH BEAN. See page 50.}

N25. LOBELIA MIXED. A. Especially desirable for edging flower beds, also for planting in hanging baskets, vases, etc., and in pots for house plants during the winter. The dwarf compact plants grow six inches high and are covered with beautiful star-like flowers. Pkt. 5 cts.; 1/4 oz. 75 cts.; oz. $\$ 2.50$

NT. LUPINUS MIXED. A. Very easily grown, The plant is about 12 inches high, and from this develops a long flower spike filled with small flowers. Excellent for cutting. Pkt. 5 cts.; oz. $20 \mathrm{cts}$.
N60. MIGNONETTE MACHET. Valued most highly on account of its delightful fragrance. Thrives best during cool weather, and we reconmend that a second sowing be made in August to furnish a supply of the flower heads during the fall. Pkt. 5 cts.; oz. $20 \mathrm{cts}$; I/4 Ib. $50 \mathrm{cts}$.

MOON FLOWER. See page 50.

\section{Nasturtiums}

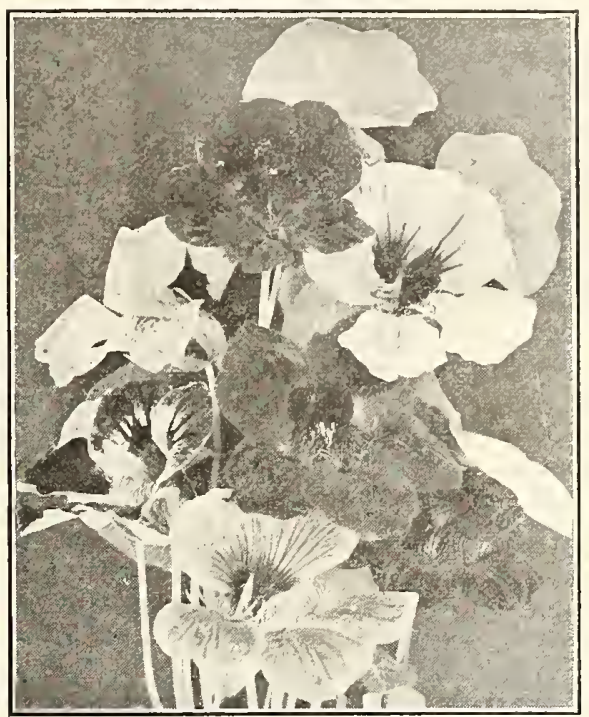

Nasturtium

\section{DWARF NASTURTIUMS}

A. There is nothing more georgeous than this easily grown annual. Allow at least 15 inches between the individual plants so as they will have anple space in which to reach perfect development.

Named Sorts: Pkt. 5 and $10 \mathrm{cts}$; $0 \mathrm{z} .20 \mathrm{cts}$; $1 / 4 \mathrm{lb}$. 60 cts.; lb. $\$ 2.00$.

Beauty. Giant Flowering Bronze.

Chameleon. Giant Flowering Variegated.

Crimson. Velvety Crimson.

Cloth of Gold. Yellow Foliage, Scarlet Flowers.

King of Tom Thumbs. Scarlet Flowers, Dark Green Foliage.

King Theodore. Crimson Maroon, Dark Foliage.

Pearl, or Moonlight. Creamy White.

Spotted King. Golden Yellow, Spotted Garner.

S40. Mixed. Pkt. 5 cts.; oz. 20 cts.; I/4 lb. 50 cts.; Ib. $\$ 1.50$ postpaid.

\section{TALL NASTURTIUMS}

A. These are at their best when planted on a steep slope and allowed to run down without any training. The plants are of strong, vigorous growth and the running shoots may be trained on ordinary fences or on wire netting. Have the plants stand 8 inches apart.

Named Sorts: Pkt. 5 and 10 cts.; 0z. 20 cts.; I/4 Ib. 60 cts.; lb. $\$ 2.00$.

Butterfly. Lemon Yellow, lower petals blotched with Terra Cotta Red.

Crimson. Velvety Crimson.

King Theodore. Crimson Maroon, Dark Foliage.

Pearl, or Moonlight. Creamy White.

Spit Fire. Brilliant Scarlet Flowers; Profuse Bloomer. Sun Light. Large Golden Yellow.

Rudolph Virchow. Handsome Rose Pink.

S51. Tall or Climbing Mixed. Pkt. 5 cts.; oz. 15 cts.; I $/ 4$ lb. 50 cts.; lb. $\$ 1.50$. 


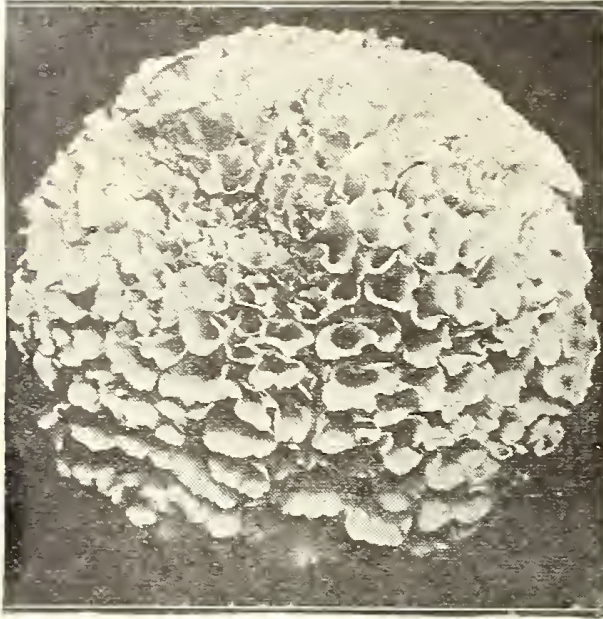

Iemon Ball Irarigold.
N46. $M$ ARI $=$ GOLD AFRI $=$ CAN LEMON B A L L. A. Yer $y$ large double flow ers of a clear canars sellow. Pkt. 10 cts.; I/4 oz. 20 cts.; oz. $60 \mathrm{cts}$.

97. $M$ ARI $=$ GOLD, AFRI= CAN ORANGE BALL. A. Tall growing bush with smooth regular orange sellow flow ers. Pkt. 10 cts.; $\quad 1 / 4 \quad$ oz. 20 cts.; oz. $60 \mathrm{cts}$.

46. MARIGOLD, TALL AFRICAN DOUBLE MIXED. A. The tall growing plants are $21 / 2$ feet high, and produce freely largely double orange and yellow flowers measuring about 3 inclies across. Pkt. 5 cts.; 1/4 oz. 15 cts.; oz. 40 cts.

N38. MARIGOLD, DWARF FRENCH DOUBLE MIXED. A. The bushes attain a height of 12 to 15 inches. The brilliant orange and yellow flowers blend nicely with the dark green, finely-cut fern-like foliage. Pkt. 5 cts.; $1 / 4$ oz. 15 cts.; oz. 45 cts.

MORNING GLORY, TALL AND JAPANESE. See p. 50. 12. MORNING GLORY, DWARF MIXED. A. (Convolu= lus Minor). Dwarf growing plants bearing profusely the brightly colorei funnel-shaped flowers. Pkt. 5 cts.; oz. $20 \mathrm{cts}$.

OXALIS MIXED. P. Small plants; foliage clorer-like; flowers small and very bright in colors. It is better to treat it as an annual. Pkt. 5 cts.

96. PANSY, GIANT=FLOWERING T R I $M$ A R D E A U MIXED. P. This is made up of a selection of the finest and largest flowering rarities, and much attention has been

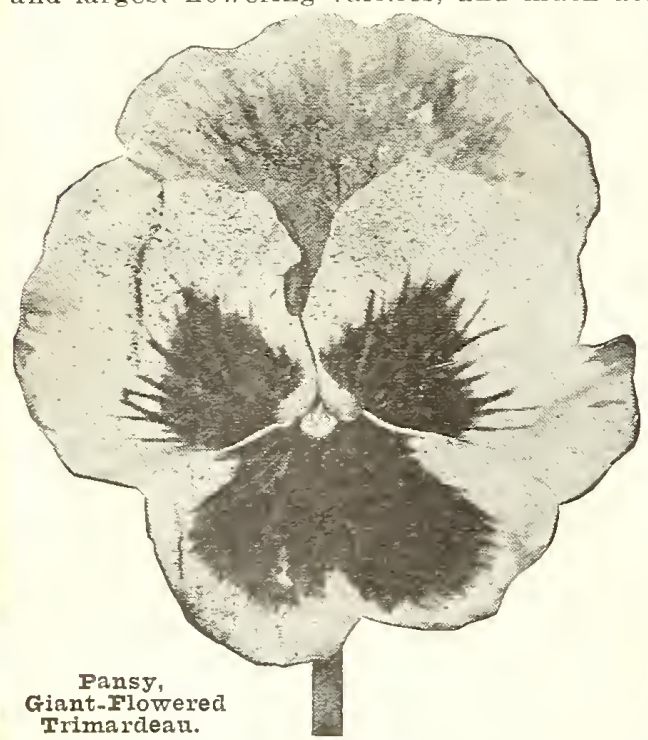
paid color com binations used. Pkt. 5 and 10 cts.; oz. $\$ 3.00$.

\section{N14.}

PETUNIA,

BEDDING

VARIETIES

MIXED. A.

As a bedding or border plant noth ing surpasses $t \mathrm{~h}$ e s e beautiful bright colored $\mathbf{P}$ e t u nias. Seed may be sown either inside in boxes or outdoors in the beds where the plants are to bloom. Pkt. 5 cts.; $1 / 2$ oz. 40c; oz, $75 \mathrm{c}$.

HATE IOL A FRIEND who would be interested in having a copy of this Catalog? If so, kindly favor us with the name and address, and a copy will be mailed at once.

31.

PETUNIA, GIANT = FLOWERED MIXED. A.

Sow seed in b o $x$ e s inside and be careful n o t to throw away the rery swall plants. as they usual $1 y$ produce the largest flow ers. This mix ture contains $\mathrm{t} \mathrm{h}$ e brightest colors. Pkt. 5 and $10 \mathrm{cts}$.

N59.

PHLOX

DRUM=

MONDII

FINEST

MIXED. A.

Vers attrac tive free-flomering plants. $S 0 \mathrm{~W}$ seed in

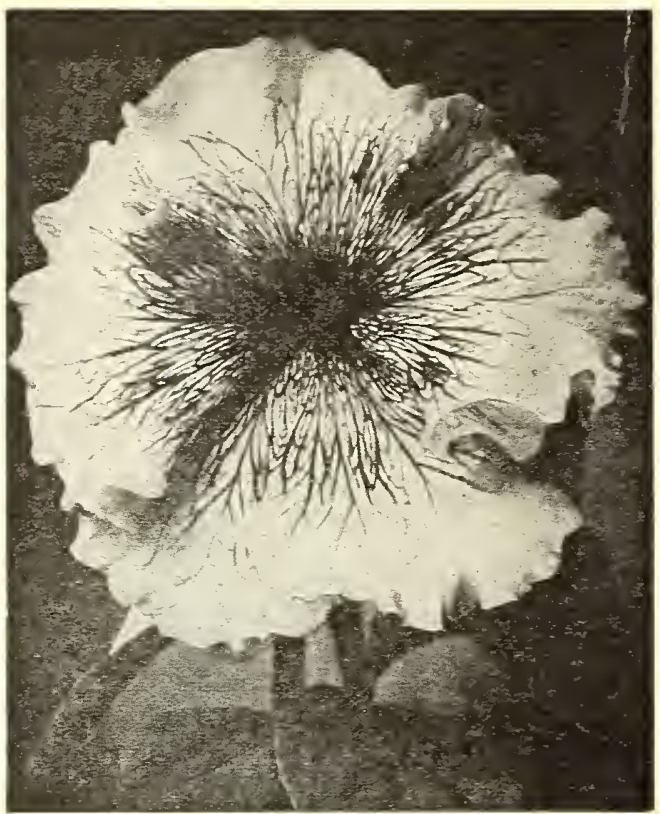

Petunia, Giant Flowered

open ground as soon as danger from frost is past. Plants bloom freely the entire season. Pkt. $5 \mathrm{cts}$.; 1/2 0z. $60 \mathrm{cts}$.; oz. $\$ 2.00$.

N13. POPPY, THE SHIRLEY MIXED. A. The large flowers are brilliantly colored and always attract much attention. Pkt. 5 cts.; $1 / 4$ oz. 10 cts.; 0z. 25 cts.

ORIENTAL POPPY. Flowers of gorgeous brilliancy. Colors from soft rose to dazzling searlet and richest maroon purple. Pkt. 5 cts.; 1/4 oz. 60 cts.; oz. $\$ 2.00$.

29. PRIMULA SINENSIS MIXED. A. (Chinese Prim= rose.) Treat as a greenhouse annual. These make splendid winter-blooming pot plants. A fine mixture of many colors. Pkt. 5 and 10 cts.

\section{PORTULAACA SINGLE MIXED. A. \\ Fine assort. ment of many brilliant $\mathrm{c}$ o l - ors. Sow seed where plants are to bloom. Pkt. 5 cts.; 1/4 oz. 20 cts.; oz. 75 cts.}

\section{N31}

PYRETHRUM GOLDEN FEATHER. $P$.

A very useful hardy perennial. Mo st desirable for edging or bordering beds filled with other plants. Pkt. 5 cts.; $1 / 4$ oz. 25 cts.; oz. 85 cts.

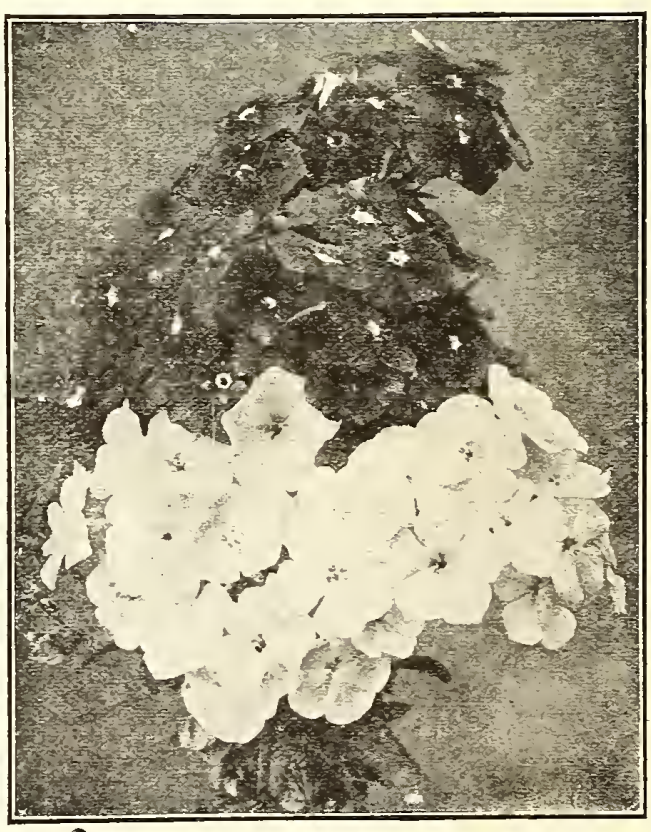

Phlox Drummondi, Finest Mixed. 


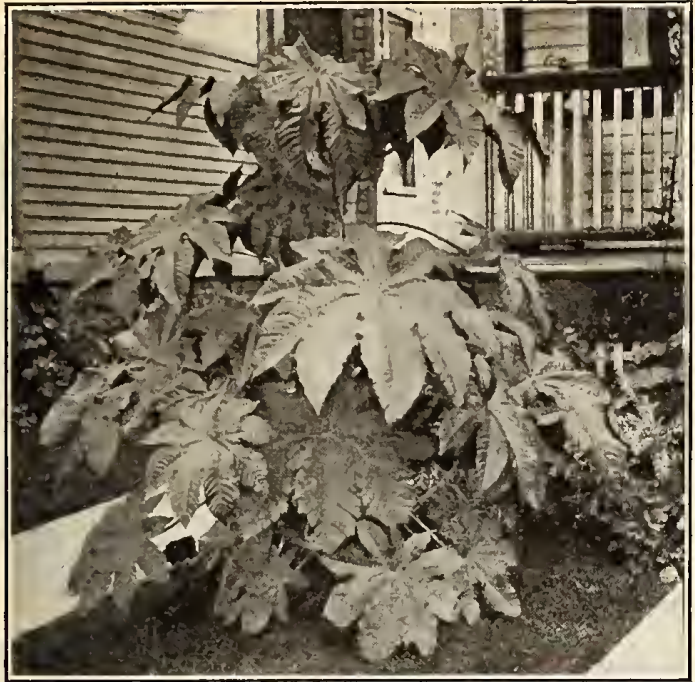

Ricinus, Castor Oil Bean.

18. RICINUS, CHOICE MIXED (The Castor Oil Bean). A. Very ornamental in growth. Recommended on lawns and for massing, or for center of beds. Pkt. 5 cts.; oz. 15 cts.; I/4 lb. 40 cts.; lb. $\$ 1.00$.

\section{SALVIA, or SCARLET SAGE}

N12. BONFIRE. A. A fine variety, $3 \mathrm{ft}$. high; forms a dense compact bush and is a heavy bloomer, having brilliant scarlet flowers. Pkt. $10 \mathrm{cts} . ; \quad \mathrm{x} / \mathbf{4}$ oz. $\$ 1.00$.

24. SPLENDENS. A. Handsome, bushy plants which produce hundreds of spikes of brilliant scarlet flowers during the early fall months. Seed should be sown early indoors; set plants in beds as soon as danger from frost is past.

Pkt. 5 and $10 \mathrm{cts}$.; T/4 oz. 60 cts.; oz. $\$ 2.00$.

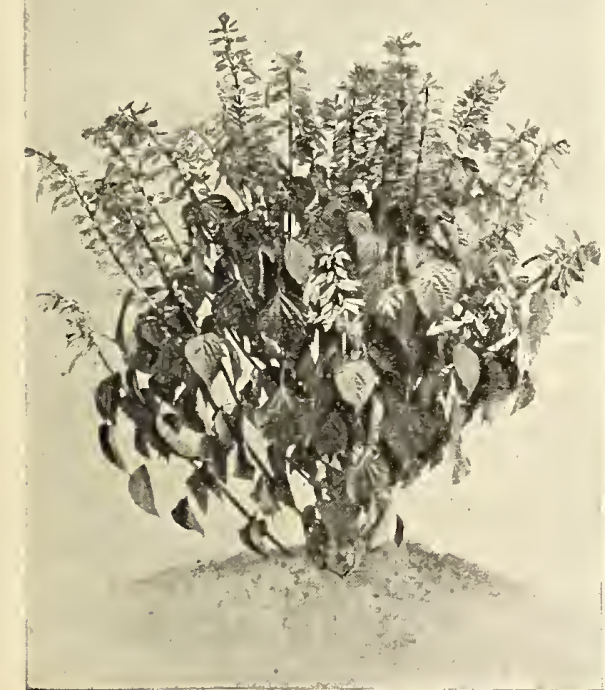

Salvia, Bonfire.
N29. SENSITIVE PLANT (Mimosa Pudica). P. In the garden this should be treated as an annual. A unique plant, the leaves of which c I o s e and droop even if only slightly to u c hed with the hand. Pkt. 5 cts.; $1 / 4$ oz. 15 cts.; oz. 50 cts.

N57. SCABIOSA M I X E D (Sweet Scabious). A. The growing plants are not o n I y highly ornamental, b u t produce freely on long stems beautifully formed flowers of many colors. Sow seed as soon as trees are starting in leaf. Pkt. 5 cts.; $1 / 4$ oz. 15 cts.; oz. 45 cts.

SCARLET RUNNER BEAN. See page 50.

100. SUNFLOWER, D O U B E CHRYSANTHEMUM= FLOWERED. A. Positively the finest sunflower in cultivation. Plants grow 7 feet high. Flowers always perfectly double and of brightest golden-yellow. Pkt. 5 cts.; oz. 30c.
N24.

SALPIGLOSIS. A. An exceedingly beautiful, showy flower, of purple, r e d, yellow, buff and blue, all delicately veined. Pkt. 5 cts.; 1/4 oz. 35 cts.; oz. $\$ 1.00$.

16. S T O C K S, D W A R F T E N WEEKS MIXED.

A. Highly recommended as a cut flower. Sow seed in hotbed or boxes and transplant into rich soil. Pkt. 5 cts.; $1 / 4$ oz. 15 cts.; oz. $\$ 1.50$.

N18. S W E E T ROCKE'T MIXED (Hesperis matron= alis). P. Plants attain a height of 2 feet and produce panicles of white and lavender flowers. Pkt. 5 cts.; r/4 oz. 15 cts.; oz. 35 cts.

20. SWEET WILLIAM, DOU= BLE AND SINGLE MIXED. P. An old-time hardy garden favorite. and so easily grown that it should have a place in all gardens. Pkt. 5 cts.; oz. 35 cts.

98. SWEET WILLIAM, BRIGH'T SCARLET. P. Pure scarlet in color, single flowers. Pkt. 5 cts.; oz. 35 cts.; $\quad 1 / 4$ lb. $\$ 1.00$.

THUNBERGIA. See page $\mathbf{5 0}$.

N32. WALL FLOWER. B. An attractive flower, very popular in Europe, having long spikes of many colors. Pkt. 5 cts.; $1 / 4$ oz. 45 cts.; oz. $\$ 1.50$.
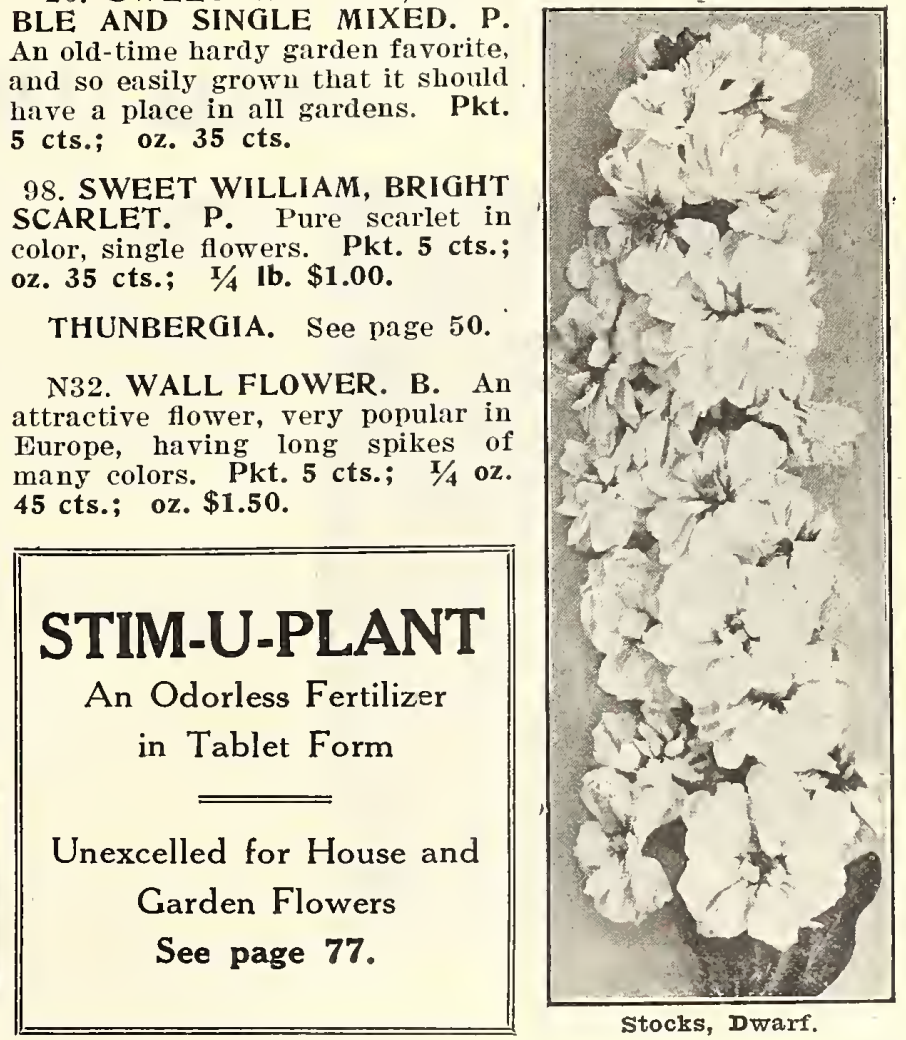

\section{For Economy's Sake}

\section{ORDER OUR SPECIAL COLLECTIONS}

FLOWERS.............Page 52

VEGETABLES .............Page 41 


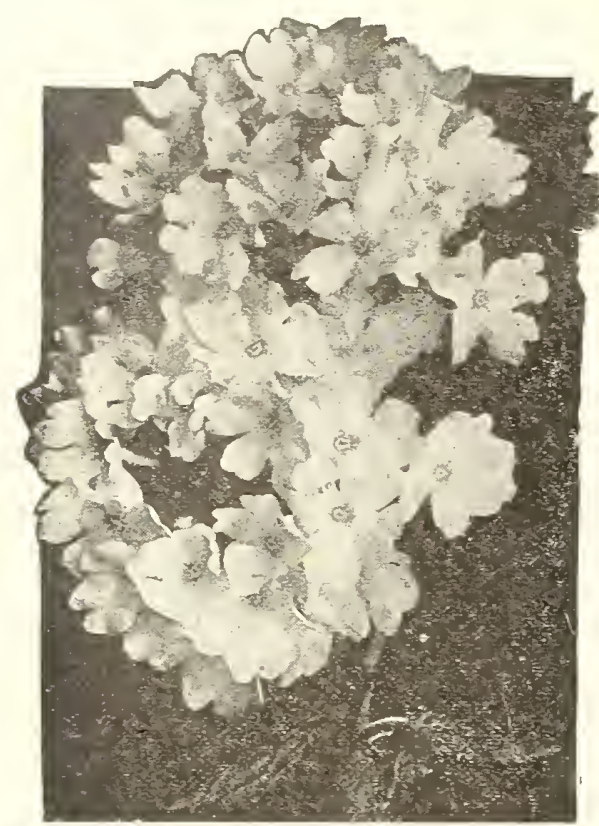

Verbena.
37. VERBENA, EXTRA FINE MIXED. P. Best treated as an annual. It grows readily from seed. The flower trusses are most attractire and the colorings are beautiful. Pkt. 5 cts.; 1/4 oz. 45 cts.; $0 z . \$ 1.50$.

\section{ZINNIA}

GIANT=FLOWERED. A. Few flowers grown from seed give the general satisfaction that Zinnias give. For brillianct and rariety of colors there is nothing that smrpasses our strain. The popularity of this flower is constantly increasing. It is frequently called "Youth and old Age," because of its constant blooming.

106. CRIMSON. Pkt. 5 and 10 cts.; oz. 75 cts.

107. FLESH PINK. Pkt. 5 and 10 cts.; oz. 75 cts.

108. SULPHUR YELLOW. Pkt. 5 and 10 cts.; oz. 75 cts.

109. WHITE. Pkt, 5 and 10 cts.; 0z. 75 cts.

110. MIXED. Pkt. 5 and $10 \mathrm{cts.}$ oz. 50 cts.; I/4 Ib. $\$ 1.75$; Ib. $\$ 5.00$.

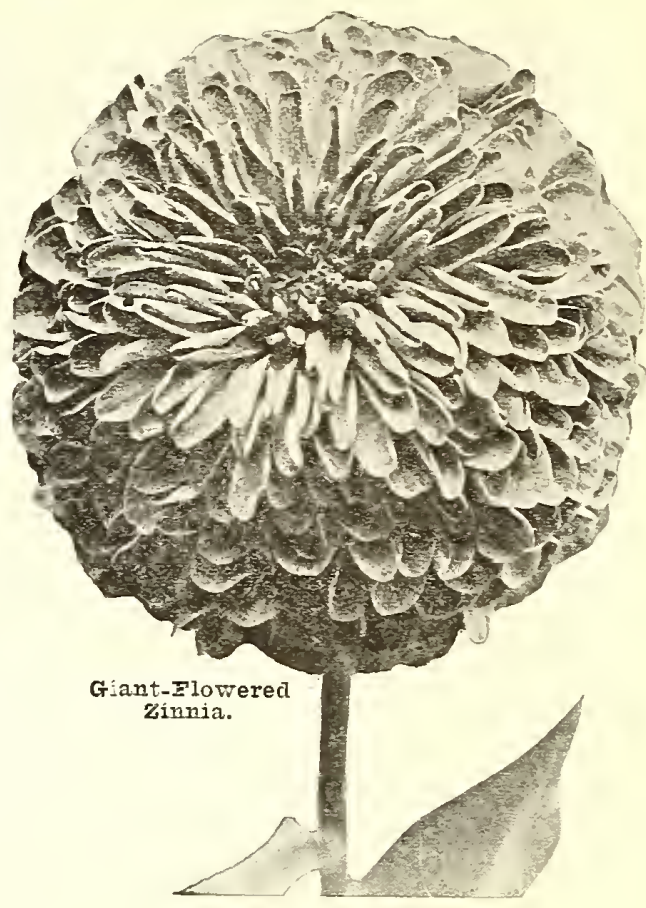

\section{ANNUAL CLIMBING VINES}

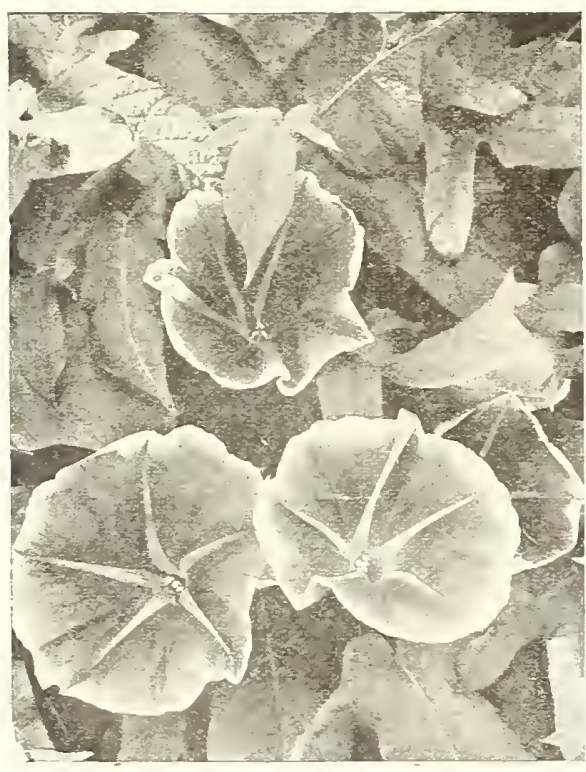

Morning Glory.
These hardy annual climbers are rery eass to grow, and it is remarkable how quickly the rines attain a great height. Any of the rarieties are suitable for covering u n s i g h t l s fences. etc.

23. B A L L O O N VINE, or "LOVE= IN=A=PUFF." A. An a t t racti $\mathrm{re}$ climber of quick growth and bears profusely inflated seed capules. Pkt. 5 cts.; $1 / 4$ oz. 10 cts.; oz. 25 cts.

43. B A L S A $M$ APPLE (Momor= dica Balsamina). A. A rapid growing vine prodncing apple-shaped fruits. Pkt. 5 cts,; 1/4 oz. 10 cts.; oz. 25 cts.

N21. CANARY BIRD VINE. A. (Tropaeolum Canariensis.) A very attractive climber, producing freels fringed sellow flowers. Pkt. 5 cts.; $1 / 4$ oz. 15 cts.; oz. 25 cts.

4. COBOEA SCANDENS. A. A rapil grower with fine foliage. Beautiful tiolet-colored bell-shaped flowers. Pkt. $5 \mathrm{cts}$.; I/4 oz. $15 \mathrm{cts}$; oz. $50 \mathrm{cts}$.

N23. CLEMATIS. P. A quickly growing rine with delicionsly fragrant flowers of pure white, blooming in sepmber. Pkt. 5 cts.; $1 / 4$ oz. 15 cts.; oz. 50 cts.
21. CYPRESS VINE MIXED. A. Finely cut fern-like foliage from which protrudes hundreds of star-like flowers. Of rerg quick growth. Pkt. 5 cts.; I/4 oz. 15 cts.; oz. 45 c.

48. GOURDS, ORNAMENTAL MIXED. A. Easily grown and the mans odd and curions fruits ale alwars a source of delight to both roung and old. Pkt. 5 cts.; 1/4 oz. 10 cts.; oz. 25 cts.

34. HYACINTH BEAN. A. A fine climber with clusters of purple or white flowers followed by ornamental seed pods. Pkt. 5 cts.; oz. 15 cts.; $1 / 4$ lb. 50 cts.

39. MOONFLOWER. A. So called because it has the characteristic of opening its flowers dnring the late afternoon and evening. The large pure white flowers contrast beatifully with the hears dense foliage. Pkt. 5 cts.; 1/4 oz. 15 cts.; oz. 50 cts.

N44. MORNING GLORY, IMIPERIAL JAPANESE MIXED. The flowers are extra large in size and of many colors. Pkt. $10 \mathrm{cts}$; 0z. $25 \mathrm{cts}$; $1 / 4$ lb. $75 \mathrm{cts}$.

26. MORNING GLORIES MIXED. A. These are easils the most popnlar of all our anmual climbers. Simply scattel the seed where sou wish the plants to grow. Pkt. 5 cts.; oz. $15 \mathrm{cts}$; $\mathrm{I} / 4$ lb. $50 \mathrm{cts}$.

NASTURTIUM, TALL VARIETIES AND MIXED. See page 47 .

N14. SCARLET RUNNER BEAN. A. A quick-growing rine bearing large sprays of bright scarlet pea-like flowers. When fully ripened the dry beans are bright scarlet, hearily blotched with purple. Pkt. 5 cts.; 1/4 Ib. 15 cts.; Ib. 40 cts.

N7. THUNBERGIA MIXED (Black=Eyed Susan). A. Neat foliage. Vines are of rapid growth and produce freely white. sellow and orange flowers, each with a black ese. Pkt. 5 cts.; $1 / 4$ oz. 25 cts.; $0 z .85$ cts. 


\section{SWEET PEAS}

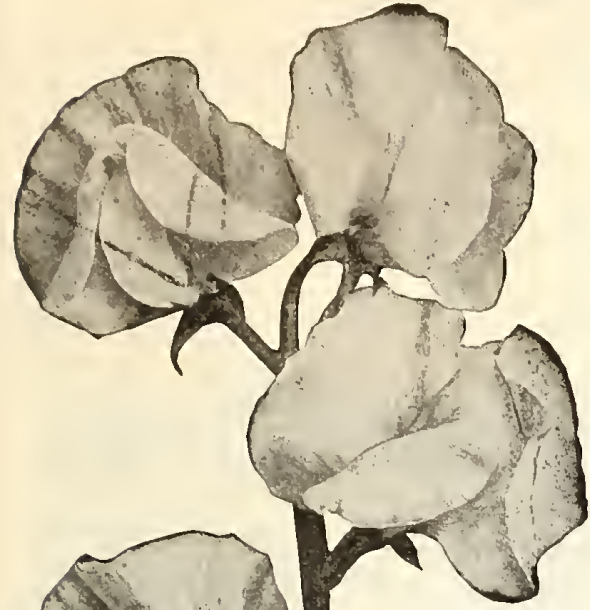

Sweet Peas have been frequently re ferred to as the poor man's Orchid solely because of the abundance of blooms, the colors which may be likened to those found in the rarest Orchids.

America for years has been looked upon as headquarters for seed of this beantiful climbing anmual, and with the result that there is now in cultivation hundreds of named varieties.

We are fortunate in having close ac quaintance with all the noted producers of Sweet I'ea seed. So we have gone over the long list of varieties repeatedly and now offer under color classification what we consider the best of their respective classes.

CULTURE. Sweet Peas should be sown in drills as early as possible in spring in rich, friable soil. Prepare the bed thoroughly, digging in a quantity of well-rotted manure, if it can be done, making a furrow 1 to 6 inches deep. In this sow the seed and cover 2 inches deep. As soon as the plants begin to show through fill in the furrow. This will secure decp planting without the bad effects of deep covering of the secd at first, and so enable the plant to bloom continuously through the heat of summer. As fast as the flowers com into full bloom they should be cut off, for if the pods ar allowed to form the plants will stop blooming. In the selection and growing of our Swcet Peas we have obtained the services of one of the leading expert Sweet Pca growers in the world, who has made the growing, propagation and developing of grand, new elegant varieties of Sweet Peas one of the highest aims of life. We, therefore, commend our extra-superior varieties to you with the assurance that if you plant them you will have, without exception, the finest collection of colors and varieties of Swcet Peas of any one in your locality.

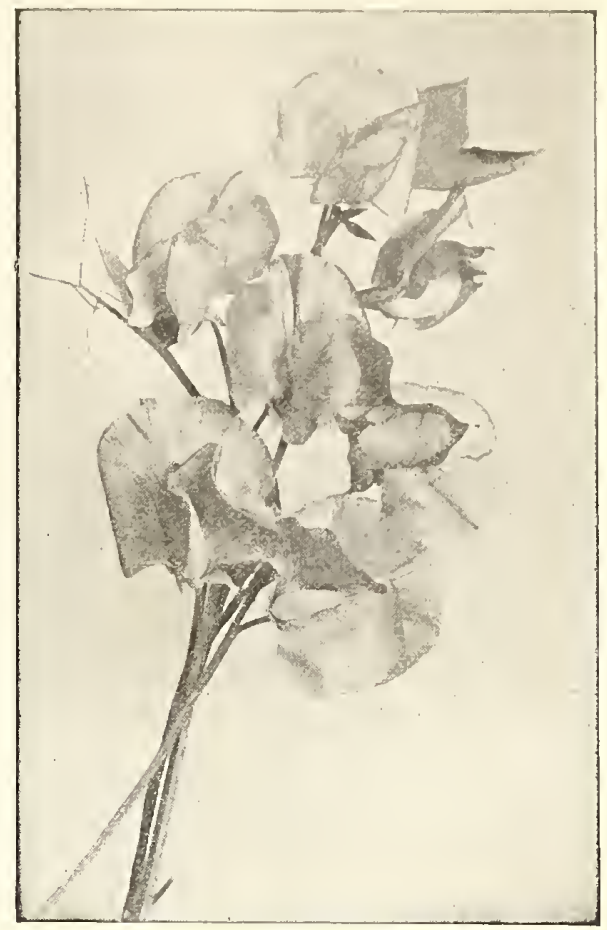

Illuminator Sweet Peas.

\section{Spencer, or Orchid-Flowering Sweet Peas}

\section{WHITE}

57. King White............10c

95. Constance Hinton.........10c

CREAM or YELLOW

39. Clara Curtis...........10c

Primrose .............10c

CREAM PINK

(Delicate Pink on Gream Ground)

53. Margaret Atlee.............10c 25c

60. Mrs. Routzahn ............10c 25c

$85 \mathrm{c} \quad 3.00$

LIGHT PINK

49. Elfreda Pearson ..........10c

$25 \mathrm{c} \quad 85 \mathrm{c}$

3.00

DEEP PINK

N55. Countess Spencer ........10c

63 . Hercules .............10c

25 c $\quad 85$ c $\quad 3.00$

SALMON PINK

91. Doris Usher ..........10c

66. Illuminator $\ldots \ldots \ldots \ldots \ldots \ldots \ldots \ldots \ldots$

25 c $\quad 85$ c $\quad 3.00$

$30 \mathrm{c} \quad 85 \mathrm{c} \quad 3.00$

ROSE

So. George Herbert ..........10c

62. Rosabelle .............10c

CRIMSON or SCARLET

s6. King Edward Spencer........10c

ORANGE

93. Fiery Cross ............ 15c

68. Helen Grosvenor ............10c

64. Thomas Stevenson ........10c
$25 \mathrm{c}$

$25 \mathrm{c}$

$25 \mathrm{c}$

$85 \mathrm{c}$

3.00

3.00

$40 \mathrm{c} \quad 1.25$

$25 \mathrm{c} \quad 85 \mathrm{c}$

$30 \mathrm{c} \quad 85 \mathrm{c}$
SALMON

Pkt, $\quad \mathrm{z}, \quad 1 / 4 \mathrm{lb}, \mathrm{Ib}$.

54. Barbara ..............10c 30c 85 c 3.00

N47. Sterling Stent...........10c 25c $85 \mathrm{c} \quad 3.00$

\section{LAVENDER}

S3. Florence Nightingale $\ldots \ldots \ldots \ldots 10 \mathrm{c} \quad 25 \mathrm{c} \quad 85 \mathrm{c} \quad 3.00$ 61. Tennant Spencer ..........10c 25c 85 c 3.00

BLUE

71. Margaret Madison ..........10c 25c $85 \mathrm{c} \quad 3.00$ 56. Wedgewood ...............10c 25c $85 \mathrm{c} \quad 3.00$ N42. Royal Purple.............10c 30c $85 \mathrm{c} 3.00$

MAROON

94. Nubian $\ldots \ldots \ldots \ldots \ldots \ldots \ldots \ldots$ 10 $25 \mathrm{c} \quad 85 \mathrm{c} \quad 3.00$ 92. King Manuel ............10c 25c $85 \mathrm{c} 3.00$

\section{$\mathrm{BI}=\mathrm{COLOR}$}

(Pink and White)

69. Blanche Ferry Spencer........10c 25c $85 \mathrm{c} 3.00$ N50. Mrs. Cuthbertson..........10c 25c 85 c 3.00

\section{PICOTTE EDGED}

N36. Dainty Spencer, white, edge pink.10c $25 \mathrm{c} \quad 85 \mathrm{c} \quad 3.00$ 88. Mrs. Townsend, white, edge pink.10c $25 \mathrm{c} \quad 85 \mathrm{c} \quad 3.00$ 87. Mrs. C. W. Breadmore, c r e a m, edged pink............10c 25c $85 \mathrm{c} \quad 3.00$

\section{STRIPED or VARIEGATED}

N41. Senator Spencer..........10c $25 \mathrm{c} \quad 85 \mathrm{c} \quad 3.00$

\section{SUPERB MIXED SPENCERS.}

This mixture not only contains all the above, but also a host of other varieties, all blended together in just the right proportion. Pkt. 10 cts.; oz. 25 cts.; 1/4 lb. 75 cts.; lb. $\$ 2.50$. 


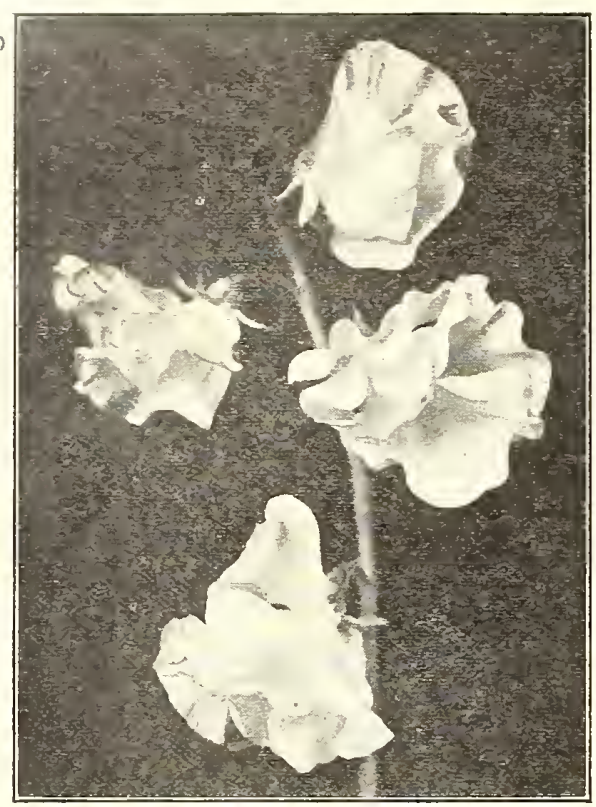

Early Snowflake Sweet Peas.

\section{Superb Early or Christmas Flowering Spencer Sweet Peas}

These varieties are a welcome addition to our lists, for they flower sereral weeks earlier than the regular Spencers, and if planted with them you will hare a much longer season of bloom.

\section{WHITE}

Pkt. Oz. $1 / 4 \mathrm{lb}$.

75. Early Snowflake

\section{PINK}

76. Early Yarrawa ........................10c 50 c 1.50

79. Early Hercules .......................10c 50c 1.50

73. Early Pink and White.....................10c 50c 1.50

S5. Early Peace ................................ 50 c 1.50

ORANGE SCARLET

77. Early Morning Star.......................10c 50c 1.50

CRIMSON

78. Early Liberty ...............

70. Early Songster .......................10c $50 c \quad 1.50$

52. Early Warbler .......................10c 50c 1.50

\section{The Best Grandiflora Sweet Peas}

In spite of the rast superiority of the Spencer or Orchid-Flowering Sweet Peas, we find there are some planters who still prefer the older or Grandiflora types.

Our list includes all the best varieties in the different color classifications.
WHITE Pkt. Oz. 1/4 lb. Lb.
BLUE Pkt. Oz. 1/4 lb. Lb.

N43. Dorothy Eckford...........5c $15 \mathrm{c} \quad \mathbf{4 5} \mathrm{c} \quad \mathbf{1 . 5 0}$

YELLOW

N33. Hon. Mrs. E. Kenyon........5c 15c 45c 1.50

5s. Prima Donna ..............5 15 c $45 c \quad 1.50$

DARK PINK

89. Janet $S$ cott ...............5c $15 \mathrm{c} \quad 45 \mathrm{c} \quad \mathbf{1 . 5 0}$

ROSE

51. Prince of Wales............5c 15c $45 c \quad 1.50$

CRIMSON or SCARLET

59. King Edward VII............

ORANGE

74. Miss Willmott ............5

\section{LAVENDER}

82. Lady Grisel Hamilton.........5

N40. Mrs. Geo. H. Higginson, $\mathrm{jr} \ldots \ldots . . .5 \mathrm{c}$ 15c $45 \mathrm{c} \quad 1.50$
81. Navy Blue $\ldots \ldots \ldots .5 \mathrm{c} \quad 15 \mathrm{c} \quad 45 \mathrm{c} \quad 1.50$

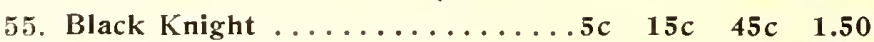

67. Othello ................

\section{$B I=C O L O R$}

(Pink and White)

S55. Blanche Ferry ...........5c 15 c $45 c \quad 1.50$

\section{STRIPED or VARIEGATED} 65. Helen Pierce..............5 15 c 45c 1.50

\section{S38. BEST LARGE FLOWERING MIXED.}

A carefully prepared mixture containing all the best American and Eckford Grandiflora rarieties. Pkt, 5 cts.; oz. $10 \mathrm{cts}$.; I/4 lb. $30 \mathrm{cts}$.; lb. $\$ 1.00$.

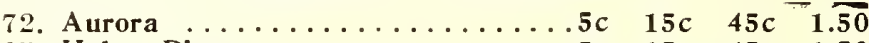

\section{Eight Charming Spencer Sweet Peas for 25 Cts.}

Sweet Peas are each season becoming more and more popular. Sow seed as early in the spring as the soil can be made ready, and bear in mind the fact that the more blooms you cut the more the vines will produce. In this collection we include the best in the different color classifications.

George Herbert. Bright carmine.

King Edward Spencer. Fine scarlet.

Dainty Spencer. White with pink edge.

Illuminator. Beautiful salmon pink.
Florence Nightingale. Soft larender.

Constance Hinton. Best white.

Margaret Atlee. Attractive cream pink.

Superb Mixed Spencers. Many colors.

\section{EIGHT SPENCER SWEET PEAS FOR 25 C'TS.}

\section{Eight Beautiful Flowers for 25 Cts.}

Nothing adds more charm to the home surroundings and. although we all realize the necessity of increasing the supply of food, yet no one should begrudge giving a small space in the garden to these brightly-colored annual flowers. All the following rarieties are easily grown and are constant bloomers.

Alyssum, Little Gem.

Antirrhinum, Half=Dwarf Mixed (Snapdragons).

Aster, Bolgiano's Special Mixture.

Eschscholtzia, Mixed (California Poppy).
Four o'Clock (Marvel of Peru).

Marigold, African Double Mixed.

Larkspur, Mixed.

Petunia, Bedding Varieties Mixed. 


\section{SUMMER FLOWERING BULBS}

These summer-flowering bulbs are very easily grown, and during the summer furnish for the house and table beatiful blooms for decorating purposes. They are not parteiular as to soil so long as it is fairly rich.

\section{Cannas}

These wonderful bedling plants give uniformly good results in all sections of the country. They succeed in any sunny position, in any kind of soil, but will repay liberal treatment. For best results spade the beds 2 feet deep, and incorporate in the soil a liberal amount of well-decayed manure of any kind. Water well at all times. The best effect

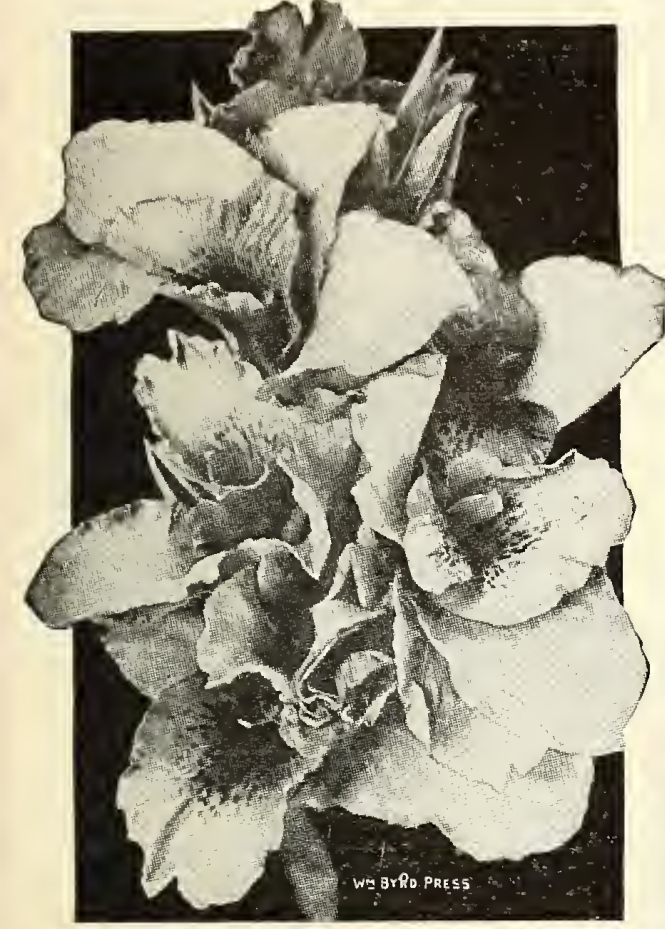

Yellow King Humbert Canna. is $\mathrm{g} i \mathrm{v}$ e $\mathrm{n}$ by planting large masses of one color, setting the plants 18 inches apart.

ROBIN HOOD In this splendid new canna w e introduce to our friends the finest pure scarlet canna that has ever been developed. Its blooms a $r$ e immense size and more $b$ e a utiful in form than any we have seen. The foliage is bright green. very heavy and remarkably strong in growth. 4 to 5 feet high. 35c each; $\$ \mathbf{3 . 5 0}$ per doz., post= paid.

THE PRESIDENT. This is described best when said to combine all the good qualities of Fire Bird with none of its faults, Blooms are pure crimson and foliage deep green Height, 4 to 5 feet. 20 cts. each; $\$ 2.00$ per doz., postpaid.

KING HUMBERT. The most popular of cannas. Gigantic orange scarlet trusses with red markings. Foliage deep coppery bronze. 5 feet tall. 10 cts. each; $\$ 1.00$ per doz., postpaid

YELLOW KING HUMBERT, or QUEEN HELEN. A yellow counterpart of the popular King IIumbert. Flowers brilliant vellow dotted with red. Foliage green. 5 to 6 feet tall. 10 cts. each; $\$ 1.00$ per doz., postpaid.

ROSEA GIGANTEA. Large trusses of soft rose to carmine-pink flowers. Blue-green foliage. Height $3 \frac{1}{2}$ feet 10 cts. each; $\$ 1.00$ per doz., postpaid.

EUREKA. Largest of pure white cannas. A free bloomer. 4 to 5 feet tall. $10 \mathrm{cts}$. each; $\$ 1.00$ per doz., postpaid.

LOUISIANA. Strong, vigorous; vivid scarlet flowers, the largest and finest of their color. 7 feet tall. 8 cts. each; 2 for 15 cts.; 75 cts. per doz., postpaid.

ALLEMANIA. Enormous flowers; broad golden border, scarlet and dark red. 5 to 6 feet tall. $8 \mathrm{cts}$. each; 2 for 15 cts.; 75 cts. per doz., postpaid.

WYOMING. Orange flowers with lighter colored border. Foliage purplish bronze. 10 cts. each; 2 for 15 cts.; 75 cts. per doz., postpaid.

\section{Gladioli}

AMERICA. The beatiful laven der-pink flowers are borne on lon stems and are firmly placed on the spike. $10 \mathrm{cts}$. each; 12 for $\$ 1.00$, postpaid.

AUGUSTA. Spikes of attractive blooms, in color white with blue anthers. $10 \mathrm{cts}$. each; 12 for $\$ 1$, postpaid.

HALLEY. Extra early bloomer with well formed flowers of an at tractive delicate rose, with white blotch. $10 \mathrm{cts}$. each; 12 for $\$ 1.00$ postpaid.

MRS. FRANCIS KING. Large spikes of beautiful light scarle flowers. $10 \mathrm{cts}$. each; 12 for $\$ 1$, postpaid.

MRS. F R A N K PENDLETON. Large flowers of a lovely flushed salmon pink with deep blood red blotches at the throat. 15 cts. each: 12 for $\$ 1.50$, postpaid.

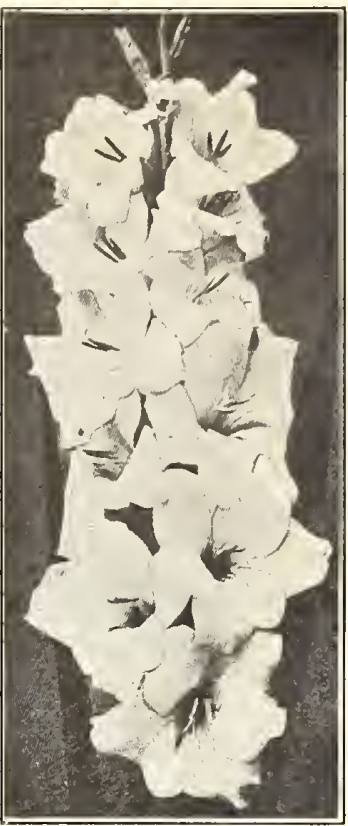

CAPITOL CITY MIXTURE. This is a special mixture comprising all the most desirable colors. The tall stalks carry long spikes of beautiful flowers. Is very easily grown. 6 for 35 cts.; 12 for 60 cts.; 50 for $\$ 1.50$, or 100 for $\$ 3.00$.

\section{Miscellaneous Bulbs}

LILLY OF THE VALLEY. Strong roots of this old garden favorite. 15 cts. each; $\$ 1.50$ per doz., postpaid.

CALADIUM ESCULENTUM (Elephant's Ear). The large leaves attain an enormous size and the single plants are most effective as individual specimens on the lawn.

Mammoth Bulbs, 11 to 13 inches, $25 \mathrm{cts}$, each.

Large Bulbs, 9 to 11 inches, $10 \mathrm{cts}$. each.

By mail, add $10 \mathrm{cts}$. each for postage.

CINNAMON VINE. A hardy climber, which grows very rapidly. The foliage is bright green in color and the white flowers are cinnamon-scented. $8 \mathrm{cts}$. each; 6 for $40 \mathrm{cts}$.; 12 for 75 cts., postpaid.

MADEIRA VINE. A very quick growing vine, bearing fragrant white flowers. 5 cts. each; 12 for 40 cts., postpaid.

EXCELSIOR PEARL TUBEROSE, Mammoth Size Bulbs. Deliciously fragrant white flowers. Plant in the garden as soon as all danger from frost is past. 5 cts. each; 6 for 25 cts.; 12 for 45 cts.; 25 for 75 cts., or 100 for $\$ 2.75$, post paid.

\section{Peonies}

ACCHILE. Rose to white. $50 \mathrm{cts}$.

COURNNE DE OR. Yellowish white. $50 \mathrm{cts}$.

ENDULUS SUPERBA. Violet rose. $60 \mathrm{cts}$.

FELIX CROUSE. Brilliant red. 75 cts.

FLORAL. TREASURE. Blush white. $75 \mathrm{cts}$.

LOUISE VAN HOUTTE. Rich rose red. $50 \mathrm{cts}$

MONS JULES ELIE. Large light pink; fragrant. $80 \mathrm{cts}$.

MONSIEUR KRELAGE. Cerese pink; extra fine and fragrant. 90 cts.

NE PLUS ULTRA. Violet rose; fragrant; very fine. \$1. QUEEN VICTORIA. White flecked with red. $50 \mathrm{cts}$.

VENUS. Shell pink, extra large ball-shaped blooms. \$1. ZOE CALLOT. Rose fragrant. $70 \mathrm{cts}$.

UNNAMED VARIETIES. Very fine strains are included among these roots, but are sold at the cheaper price because they are mixed. $40 \mathrm{cts}$. each. 


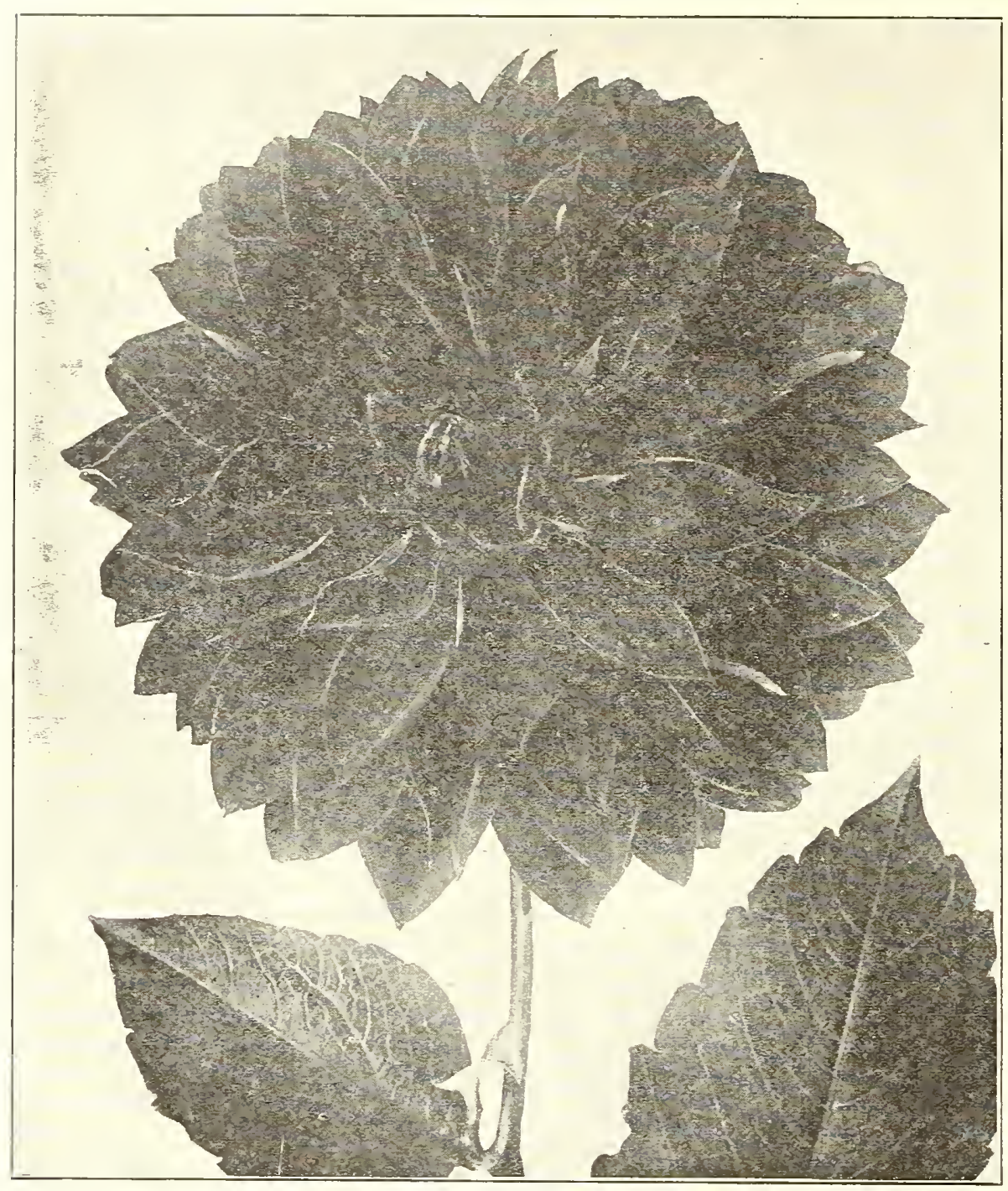

Mina Burgle Dahlia.

\section{DAHLIAS}

We wish to call particular attention to the number of splendid new rarieties we are offering to our customer's this year. It is always our dosire to furnish the best, and we feel that we are justly proud of what we are listing below.

The Dahlia is of the easiest possible culture. Plant in good soil in the full sunlight, and keep the ground well worked or mulched. and sou will be repaid by showers of bloom.

One Each of All Dahlias Lisred, $\$ 7.50$, Postpaid.

\section{FOUR NEW GIANT DAHLIAS}

For size, coloring, form and rigor of growth. these varieties are in a class by themselres.

The four for $\$ 1.50$.

L. KRAMER PEACOCK. The ideal white decorative, for garden or cutting. The flowers are large, of perfect form, pure white and of great substance, keeping a long time after being cut. The plant is a strong vigorous gromer, of dwarf branching habit, and a profuse bloomer. 40 cts. each; 6 for $\$ 2.25$.

MRS. ROOSEVELT. A most beautiful flomer. It is of immense size, fine color. sraceful form and has excellent stems for cutting. Flowers are 6 to 5 inches in diameter. Delicate pink, shading to soft pink, $40 \mathrm{c}$ each; 6 for $\$ \mathbf{2 . 7 5}$.
MINA BURGLE. This new introduction is one of the finest rarieties to date a champion rariety, producing flowers of gigantic size and remarkable beauty; the best in existence. Color, a glowing and most brilliant scarlet. The flowers are of perfect Decoratice trpe. and are borne upon long. wiry stems well abore the foliage. Attracts unirersal attention. $50 \mathrm{cts}$. each; 6 for $\$ 2.75$.

BREAK 0' DAY. A new giant dahlia that should be in erery collection. Of immense size and irregular formation. A delicate clear sulphur yellow, tinting to sulphur white at the tips. The petals are of great substance illuminated by a satiny sheen, giving the flowers a max appearance. A strong rigorous grower and free bloomer with long erect steins. $50 \mathrm{cts}$. each; 6 for $\$ 2.75$.

\section{NEW PEONY-FLOWERED}

HORTULANUS BUDDE. Gorgeous Holland Peonf-flow. ered Dahlia. A bright deep red: of splendid habit. One of the most reliable. 25 cts. each; 6 for $\$ 1.35$.

JOHN GREEN. Fellow, tipped red, irregularly formed petals: early and extremely profuse bloomer. 30 cts. each; 6 for $\$ 1.65$.

NATALIE. Yery large. lilac edged larender. Fine form and profuse bloomer on long stems. 30c each; 6 for $\$ \mathbf{1 . 6 5}$.

\section{DAHLIAS - The Four for $\$ 1.00$.}

QUEEN WILHELMINA, Giant Holland Peony=Flowered Dahlia. Largest and finest of the pure white sorts; excellent for decoratire Tork and unsurpassed as a cut flower. Blossoms produced upon long, graceful stems. Tell abore the foliage. An immense, fluffy flower of pure glistening white, showing its beautiful golden-yellow center very prominently, which lends an additional charm to this most beautiful flower. 25 cts. each; 6 for $\$ 1.35$. 


\section{PLANT SECTION}

Some firms are sending out mailing size roses that are hardy more than rooted cuttings: we do not handle that kind; our plants are grown in 3-inch pots, are strong and rigorous and ready to bloom at once. These are sent to "rou postpaid at the prices quoted. It will be better, how"ever", for you to hate them come by express, as all the soil can then be left on the roots, which is a great adrantage.

Our two-year Roses were all in bloom last summer, and are winteled outdoors where they have an entire rest; these are not like the exhausted hothouse plants sold by some; they go by express at rour expense at the price giren.

PRICES ON ALL ROSES

$1=y$ ear Mailing Size, 35 cts., postpaid.

Strong 2=year Plants, $\$ 1.00$.

Weight, per plant, about 1 pound.

\section{Hardy Hybrid Tea Roses}

BESSIE BROWN. White, sometimes flushed pink.

COLUMBIA. Peach Blow pink.

GRUSS AN TEPLITZ. Richest scarlet, shading to relretr crimson.

HOOSIER BEAUTY, Rich crimson, scarlet.

JONKHEER J. L. MOCK. Bright pink, faced carmine.

KAISERINE AUGUSTA VICTORIA. Soft pearly white, tinted lemon.

LADY ALICE STANLEY. Deep coral rose, inside delicate pink.

MADAM CAROLINE TESTOU'T. Brilliant sating rose.

MADAM CONSTANT SOUPERT. Deep yellow, edged with deep feathered pink.

MRS. AARON WARD. Indian rellow, shading lighter to ward the edge.

OPHELIA. Salmon flesh, shaded with rose.

RADIANCE. Rich silvery pink.

RED RADIANCE, Clear cerise red,

RHEA REID. Vivid scarlet crimson.

RICHMOND. Brilliant scarlet crimson.

SUNBURST. Orange copper blended with golden orange and rellow.

W. R. SMITH. White orerlaid with clear, bright pink.

\section{Tea Roses}

MADAM FRANCISCA KRUGER. A deep coppery yellow. PINK MAMAN COCHET. Rich pink, changing to silrerr rose.

WHITE MAMAN COCHET. Pure white.

\section{China Roses}

CLOTHILDE SOUPERT. Soft shell pink.

FRAU KARL DRUSCHKI. The best pure white.

QUEEN'S SCARLET. Bright, fiery scarlet.

\section{Everblooming Climbing Roses}

CLIMBING CLOTHILDE SOUPERT. Irory white. CLIMBING KILLARNEY. Deep shell pink.

CLIMBING JULES GRAVERAUX. White tinted with blush pink, with rellow base.

CLIMBING PAUL NEYRON. A fine pink color.

EMPRESS OF CHINA. Soft red, becoming a brighter shade as the flower ages.

MARECHAL NEIL. Superb bright golden yellow.

MARY WASHINGTON. Medium sized flowers of pure white.

MRS. ROBERT PEARY. Large pure white flowers.

PAUL'S SCARLE'T CLIMBER. VividIy brilliant scarlet.

\section{Rambler Roses}

AMERICAN BEAUTY. Fine dark pink to red.

CRIMSON RAMBLER. Brilliant crimson.

DOROTHY PERKINS. Lorely shell pink.

WHITE DOROTHY PERKINS. Pure white.

RED DOROTHY PERKINS. Fine pure red.

TAUSENDSCHOEN. Soft pink, changing to carmine.

\section{FRUIT DEPARTMENT}

APPLE TREES. 4 to 5 feet. $\$ 1.00$ each; $\$ 8.00$ per 10 . Winter Varieties: Delicious, Stayman, Jonathan, Winesap, York Imperial, Mammoth Black Twig.

Autumn Varieties: Grimes Golden, Maiden Blush.

Summer Varieties: Yellow Transparent, Early Harvest. PEAR TREES. 4 to 5 feet. \$1.50 each; $\$ 12.50$ per 10. Varieties: Barlett, Seckel, and Kiefer.

CHERRY TREES. 4 to 5 feet. \$1.50 each.

Sour Varieties: Montmorency, Early Richmond.

Sweet Varieties: Tartarian and Yellow Spanish.

QUINCE TREES. 4 to 5 feet. $\$ 1.50$ each.

PEACH TREES. Assorted ralieties early to late. 65 cts. each; $\$ 4.00$ per 10 .

RASPBERRIES (BLACK CAPS). $20 \mathrm{cts}$. each; $\$ 1.00$ per 10.

Varieties: Cumberland, Kansas, and Gregg.

RASPBERRIES, RED. 20 cts, each; $\$ 1.00$ per 10.

GRAPE VINES. $35 \mathrm{cts}$, each.

Varieties: Concord, Niagara, Worden, Moores, Early, and Delaware.

HORSE RADISH. 20 cts. each; $\$ 1.50$ per 10. STRAWBERRIES. $\$ 1.50$ per $100 ; \$ 8.00$ per 1,000 .

Varieties: Aroma, Gauds, Early Ozark, Klondrke:

EVERBEARING STRAWBERRIES. \$3 per 100; \$12.50 per 1,000

Varieties: Progressive, Superb.

\section{SHADE TREES}

NORWAY MAPLE. 10 to 12 feet. \$2.50 each.

SILVER MAPLE. \& to 10 feet, \$1.00 each; 10 to 12 feet, $\$ 1.50$ each.

ENGLISH WALNUT. 2 to 6 feet. \$1.00 each. CATALPA BUNGEI, GRAFTED. \$3.00 each.

LOMBARDY POPLAR. 12 to 14 feet. \$2.00 each; \$10 per 10.

ORIENTAL PLANE. 12 to 14 feet, $\$ 3.00$ each; 8 to 10 feet, $\$ 1.50$ each.

HORSE CHESTNUT. \& to 10 feet. \$3.00 each.

AMERICAN LINDEN, 10 to 12 feet. \$3.00 each.

AMERICAN ELM. 10 to 14 feet. \$3.00 each.

\section{EVERGREENS}

ARBORVITAE, American. Tall rapid grower. 2 to 3 feet, $\$ 1.50 ; 31 /$ to 4 feet, $\$ 3.50 ; 41 / 2$ to 5 feet, $\$ \mathbf{5 . 0 0}$.

Pyramidal. Dense dark green foliage. 2 feet, \$2.00;

3 feet, \$3.00; 4 feet, \$4.25.

Globe. Dwarf low growing. 12 to 15 inches, $\$ 1.50$.

GOLDEN ARBORVITAE. Foilage light yellow. 1S to 24 inches, \$2.50; 2 to 3 feet, $\$ 3.50$.

BIOTA ORIENTALIS. 15 to 18 inches, $\$ 1.50 ; 2$ to 3 feet, \$2.00.

CEDARS, Communis Prostrata. Low spreading types. $11 / 2$ to 2 feet, $\$ 2.00 ; 21 / 2$ to 3 feet, $\$ 3.50$.

Red. Nursery grown. 3 to 4 feet, $\$ 2.00 ; 4$ to 5 feet, $\$ 4$.

Tufted. Dark green fluffy foliage. 2 to 3 feet, $\$ 4.00$.

RETINISPORAS, Pisifera. 15 to 18 inches, $\mathbf{\$ 1 . 5 0 ; ~} 2$ to

$21 / 2$ feet, $\$ 3.00 ; 4$ to 5 feet, $\$ \mathbf{5 . 0 0}$.

Plumosa. 18 inches, $\$ 1.50 ; 21 / 2$ to 3 feet, $\$ 3.50$.

Squarrosa, Silver Retinispora. 15 to 18 inches, \$2.00; 2 to $21 / 2$ feet, $\$ 3.00$.

SPRUCE, Norway. Rapid grower; fine specimen. 18 to 24 inches, $\$ 1.50 ; 3$ to 4 feet, $\$ 3.50$.

Engleman. Dull blue foliage. 2 to 3 feet, $\$ 3.50$.

Colorado Blue. $11 / 2$ to 2 feet, $\$ 2.50 ; 2$ to $2 \frac{1}{2}$ feet, $\$ 4$; $21 / 2$ to 3 feet, $\$ 6.00 ; 3$ to $31 / 2$ feet, $\$ 7.00$. 


\section{HARDY FLOWERING SHRUBS}

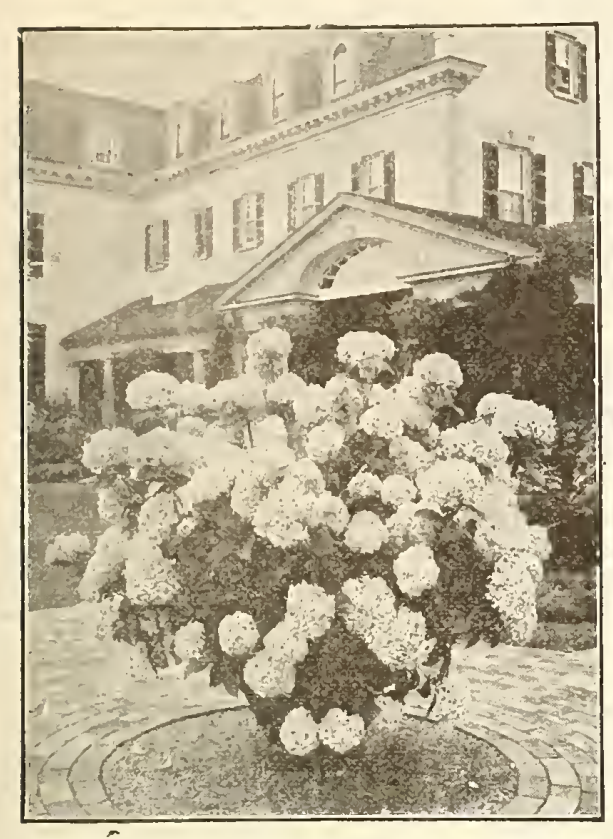

IIyclrangea.
To bring out the full effect of the beauty of Annual and Perennial flowers, there is nothing equal to a $\mathrm{h}$ a $\mathrm{r}$ -
monious background of hardy flowering shrubs. Our seleetion is designed for the average home, and will enable the owner to have a beautiful flowers for the spring, summer and autumn, in addition to the added color of berries, fruit, leaves and bark, all of which more enjoyable at all seasons. Our shrubs are of tested varieties and sold at prices which will enable you to beautify your grounds at en eost. Experionly grow and ship our stocks, which will succeed with a reasonable amount reasonable amount of care and atten-
tion, and give a lasting pleasure.

Prices are for stock at our store, or packed ready for shipment at the Nurseries near Washington, D. C.

AITHEA. Rose of Sharon. Bloom in August and September, large, bright, single and double flowers. Fine specimen border or hedge plants; stand clipping wet, $75 \mathrm{cts}$, each; $\$ 5.00$ per 10 .

ARONA. Small white tinted flowers followed by bright blackberry-like fruits, valuable to attract birds. 2 to 3 feet, $75 \mathrm{c}$ each.

CAIYCANTHUS. Old-time sweet shrub; queer, strong-scented flowers, sometimes called Carolina Allspice. 2 to 3 feet, $90 \mathrm{cts}$.

CEANOTzUS. New Jersey Tea; dwarf shrub; white flowers in dense clusters all summer. 2 to 3 feet, $75 \mathrm{c}$ each. Improved variety, light blue flowers, 2 to 3 feet, $\$ 1.00$ each.

CORNUS SIBERICA. Siberian Dog Wood. Valuable for its white berries and scarlet red twigs in winter. Yellow twigged variety for contrast will grow in damp and shady places. 2 to 3 feet, $60 \mathrm{cts}$; 3 to 4 feet, $75 \mathrm{cts}$., 10 for $\$ 5.00$.

CYDONIA. Flowering Quince. A grand old-time shrub covered in spring with dazzling scarlet flowers. Good foliage and thorns will protect your lawn from people who like to make short cuts. 2 to 3 feet, $75 \mathrm{cts}$. each.

DUTzIA. Several varieties ranging in height from 2 to 16 feet. Crenata. Tall, with double pure white flowers; a very handsome free-flowering plant.

Pricle of Rochester. 'The largest white flowering variety.

Crenata Rosea. Fine clusters of single pink flowers.

The above varieties of Dutzia, 2 to 3 feet, $60 \mathrm{cts}$. each, $\$ 5.00$ per ten: 3 to 4 feet, $70 \mathrm{cts}$. each.

Gracillis. Dwarf growing, very bushy, covered with pure white lowers in May; a splendid edging or low hedge plant. 18 to 24 inches, $75 \mathrm{cts}$.

IIIACS. The most charming of flowering shrubs.

Vulgaris. The old-fashioned lilac, light purple flowers.

vulgaris Alba. The old-fashioned white lilac. 3 to 4 feet, 80 cts. each, $\$ 6.00$ per 10.

Charles $\mathbf{X}$. Loose trusses of single flowers of reddish purple, fast grower with large glossy leaves.

Pres. Grevy. Huge panicles of beautiful shape of light blue.

Souv. de Indwig Spaieth. The most beautiful of the dark blue

French.

Frail Bertha Damon. Extra large trusses of pure white flowers.

Mad, Iemoine. Double pure white, very fine.

The abore five varieties -3 to 4 feet, $\$ 1.00$ each; 2 to 3 feet, $80 \mathrm{cts}$. each, $\$ 7.50$ per 10 .

FORSYTHIA. Golden Bell. One of the first shrubs to bloom in the spring: masses of bright golden yellow flowers before the leaves appear.

suspensa. Graceful shrub with long slender branches; dark green foliage; can be trained on trellises or arches.

Intermedia. The first to bloom, more upright grower than Suspensa.

Viridissima. Tall grower with golden flowers. 3 to 4 feet; $75 \mathrm{cts}$. each, $\$ 5.00$ for 10 .
HYDRANGEA. Arborescens Grandiflora. Banks of Snow, All summer flowering shrub; large, pure white llowers. Heads 75 cts. each, 10 for $\$ 5.00$.

Paniculta Grandiflora. This grand old shrub is one of the most showy shruls during August and September. Massive white blooms, pure white, turning to pink and then to bronze Can be grown in tree form for specimen or kept low for mass plantings. 2 to 3 feet, $90 \mathrm{cts}$. each.

IONICERAS. High Bush Honeysuckles. Bright, pretty, fragrant flowers in spring followed by showy berries through the fall and early winter. A wonderful plant to altract birds. very good hedge plant.

Fragrantissima. Pink and white flowers early in spring, fragrant.

Morrowii. 4 to 6 feet: pure white flowers early in spring, followed by bright red berries.

Rubra. Deep rose pink; flowers in June.

The above five sorts- 2 to 3 feet, $50 \mathrm{cts}$ each; 3 to 4 feet, $80 \mathrm{cts}$. each.

\section{PHILADELPHUS. Mock Orange.}

Avelanche. Very large fragrant flowers on slender branches which arch gracefully to the ground.

Grandiforius. Very large white flowers in June.

Isemoines Erectus. Tall shrub, fine foliage, creamy white flowers in June.

The a

SYMPHORICARPUS, RACEMOSUS. SnOW Berry. Small shrub, small pink and white flowers in July and August. Clus-
ters of waxy white berries in the autumn. 3 to 4 feet, 80 cts.
each, $\$ 7.00$ for 10. each, $\$ 7.00$ for 10.

Vulgarius. Coral berry. Small shrub, dark green foliage, dark red fruits cluster's around graceful branches, Valuable plant for dry shady positions. 2 to 3 feet, $75 \mathrm{cts}$. each, $\$ 4.00$ per' ten.

SPIREAS. Argueta IMultiflora. Snow Garland. Drooping branches. A snowy mass of clear white flowers in May. 2 to 3 feet, $70 \mathrm{cts}$. each.

Opuifolia, Nine Bark. Tall grower, 8 to 10 feet: white flowers in June, turning to a dark red. 3 to 4 feet, $75 \mathrm{cts}$. each.

Pruniflora, Briclal Wreath. Very effective shrub covered with mall double white flowers. 3 to 4 feet, 75 cts. each.

Anthony Waterer. Blooms all summer with panicles of crimson flowers. 18 to 24 inches, 75 cts.

Van Fouteii. The grandest of all the spireas, and one of the best flowering shrubs. Wonderful show of bloom in late May and early June. 2 to 3 feet, $75 \mathrm{cts}$. each; 3 to 4 feet, $85 \mathrm{cts}$. each, $\$ 6.00$ per 10 .

Callosa Alba. Large flat clusters of white flowers nearly all

Thunbergii. Fine shrub, 3 to 4 feet, having graceful arching branches with long sprays of white flowers in early spring three last varieties of dwarf Spireas, 2 to 3 feet, $75 \mathrm{cts}$. each, $\$ 5.00$ per 10.

VIBURNUM. Opulus sterilis. The old-time snowball. White balls of pure white flowers. As a rule in full bloom Decoration Day. $75 \mathrm{cts}$.

Plicatum. Japanese Snowball. Of erect, compact growth. A solid mass of pure white in June. 3 to 4 feet, $\$ 1.00$ each.

WEIGELIA. Beautiful, free blooming shrubs, nluch used in borders and as specimcn plants for the lawn.

Candida. 4 to 6 feet. Pure white blooms in great profusion June.

Fva. Rathka. One of the most valuable. Flowers deep earmine red. June and July, 2 to 3 feet; $60 \mathrm{cts}$.

WISTrEIA. Pale blue flowers. 2 to 3 feet, $90 \mathrm{cts}$.

\section{HEDGE PLANTS}

Japanese Barberry. The best and most practical low hedge plant. It also makes a good footing or base planting near the house or as a border plant in front of tall growing shrubs. 'They' can be allowed to grow naturally or pruned into any hedge form desired.

12 to 18 inches.

Per $10 . \quad 100$.

18 to 24 inches.

$\begin{array}{rr}\$ 3.00 & \$ 20.00 \\ 4.50 & 35.00\end{array}$

California Privet. The best known hedge plant'. Dark green foliage which hangs to the plant until midwinter.

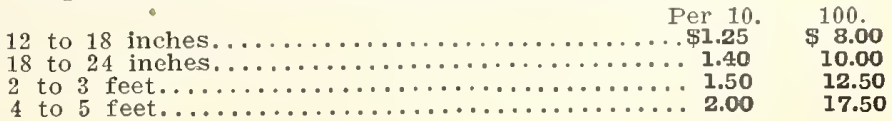




\section{BABY CHICKS BY MAIL}

The elimination of doubt in incubating eggs has been such a boon to poultr: $r$ a is ers that the baby chick business. at first a subject of ridicule, has become one of the largest departments of the poultry business.

Our trade in babs chicks has increased with such rapidity that it is almost impossible to tell with

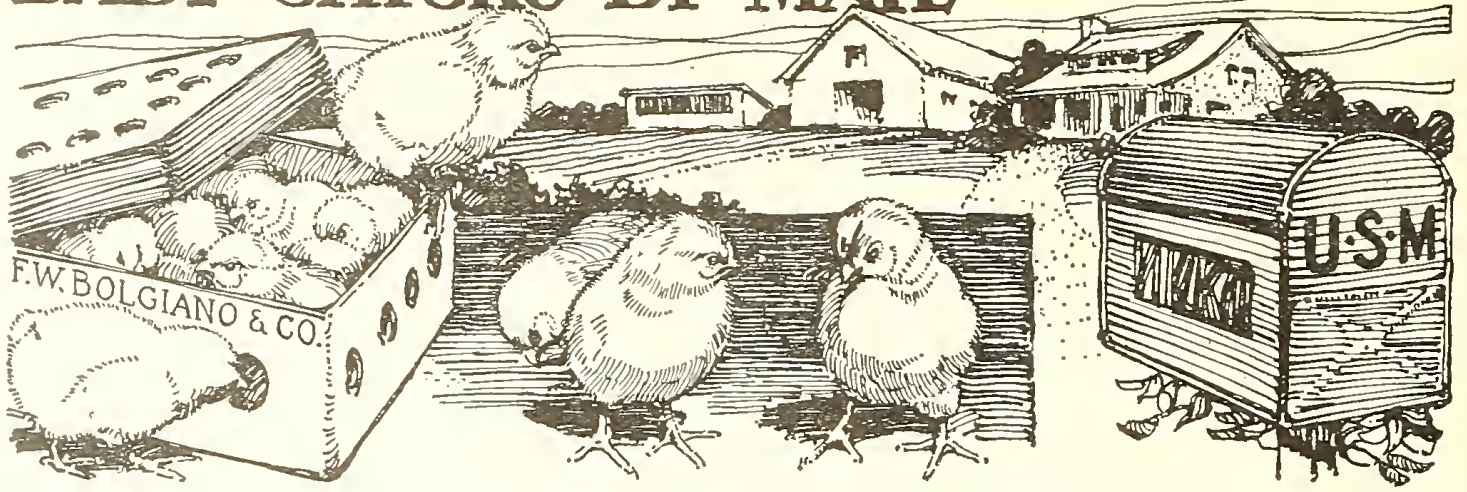

absolute certainty That proportions our sales will be the coming season. Nerertheless, we know that the safest plan for our friends to follow is not to wait until late in the season or until a fex days before you wish the chicks, but to order early and be sure of getting your order in good time.

Be sure when mriting us that rour full name and postoffice is rery plainls giren. State plainly the number and rariety of chicks you want, when wanted, and we will acknowledge receipt of your order at once, and tell you about when the chicks will be shipped.

Cash must be sent with rour order, for tre cannot ship C. O. D.. by express or parcel post.

We guarantee to delirer 97 per cent of the Babs Chicks to rou in good condition.

\section{Examine the Shipments}

on arriral open box. if any chicks are dead have postman mark number on the back of the receipt and return the receipt to us, and we will refund your moner for them or replace them free of charge. In this way you hare no loss and get full number you pay for. We hare successfully shipped baby chicks 1.000 miles and can guarantee safe arriral.

All claims must be made within trenty-four hours, together with a statement from your postmaster, showing the chicks wele receired in poor condition.

Hare the brooder warmed up and readr to receive and care for the chicks properly.

Don't gire baby chicks cold water to drink. Don't orerfeed chicks. Either of the abore will start bowel tronbles. Feed liberally, so Iong as ther keep active. Keep their backs warm.

\section{Single Comb White Leghorns}

The erer-increasing demand for Leghorn eges in the New York market has led obserring poultrymen and farmers to look to the Leghorn hen for highly profitable results.
"America"s Business Hen" has proren a winner, and todas there are hundreds of large and small commercial Leghorn farms successfull 5 operated in New York, New Jerses, Marsland and right through to the South and far Western coast.

\section{Single Comb Brown Leghorns}

That the modern Single Comb Brown Leghorn is the most beautiful rariety in color and markings of the Leghorn family is generally admitted.

Many breeders of Bromn Leghorns consider their eggproducing quality of very great importance. They lay a well-shaped white egg, weighing from 24 to 26 ounces to the dozen.

\section{Barred Plymouth Rocks}

The Barred Plrmouth Rock is most widely known as a general purpose fowl, a breed which has proven its ralue as a market fowl and an egg producer. They are extremely and well adapted as a profitable and popular farm flock.

Tie breed for constitutional rigor, thereby maintaining the greatest ritality of the flock to attain as high an egg production as is consistent with retained vitality.

\section{Rhode Island Reds}

As a "business hen" for eggs and meat they are hard to beat. They lay a well-shaped, good-sized brown egg, and mostly uniform in shape, size and color.

The matured feathering of the Rhode Island Red is not as yet uniform in coloring. This is being improred each year, to the great credit of hundreds of our best breeders of America.

We can also supply other varieties you may wish, and will gladly answer your inquiries with lists and prices.

\section{BABY CHICKS AND EGGS}

\section{Variety.}

S. C. White Leghorns

S. C. Brown Leghorns

Barred Plymouth Rocks.

S. C. Rhode Island Reds. .

R. C. Rhode Island Reds.

S. C. Black Minorcas

White Plymouth Rocks.

White Wyandottes

25
Chicks
.$\$ 6.00$
.6 .00
.6 .50
.$\quad 6.50$
6.50
.7 .00
.9 .00
7.00

\section{0}

Chicks.

$\$ 11.00$

11.00

12.00

12.00

12.00

13.00

16.00

13.00

\section{0}

Chicks.

$\$ 20.00$

20.00

22.00

22.00

22.00

25.00

30.00

25.00

500
Chicks.
$\$ 95.00$
95.00
105.00
105.00
105.00
120.00
120.00
120.00

\begin{tabular}{c}
15 \\
Eggs. \\
$\$ 3.00$ \\
\hline 3.00 \\
3.00 \\
3.00 \\
3.00 \\
3.00 \\
3.00
\end{tabular}

50

Eggs.

$\$ 7.00$

7.00

7.00

7.00

7.00

7.00

7.00
100

Eggs.

$\$ 12.00$

12.00

12.00

12.00

12.00

12.00

12.00

If prices are reduced at the time of shipment the purchaser will be proportionately credited with the amount due or enough additional Chicks shipped to make up the difference, or money will be refunded.

If Chicks ordered are not wanted for a month or more 25 per cent of payment is all that is required at the time of placing order. Balazce must be paid ten clays before date given for slipment. All orders are acknowledged same das received, with approximate late of shipment given. 


\section{"Everything for the Poultryman"}

CONSUL'T 'THE MANAGER OF OUR POULTRY SUPPLY DEPARTMENT'

When we started our Poultry Department our aim was to be the largest and best known in this city, and we are rapidly reaching our goal. This is an indication that we hare pleased our customers.

Look over this section of our catalogue, no matter how few chickens you keep; you will bind something that will be a labor-saver and a profit-niaker.

If you caunot find what you want in this catalogue, we have it at the store, or can get it for you without a minute's mnecessary delay. Be sure to get a bottle of FEL-SUL, see page 62.

\section{PRAIRIE STATE INCUBATORS AND BROODERS}

\section{YEARS AT IT BRINGS SUCCESS}

The development of Prairie State equipment to its present high degree of perfection was not due to chance, but to years of hard, diligent study and experiment along scientific as well as practical lines. A great many people have entered into the manufacture of incubators and brooder's with the crude idea that it did not require any special knowledge or experience to produce successful equipment. This accounts for so many impractical machines being foisted upon an unsuspecting public, and also for the prejudice which many people still hare against incubator and brooder.

We all know it is no easy task to imitate nature, and especially is this true in the process of changing the outwardly inanimate nature of an egg into a living chick. Even the hen has her troubles, sometimes complete failure. Then, is it not reasonable to assume that to build a machine to do the work of nature it must be made on scientific principles and in a thorough workmanlike manner?

This accounts for the fact that Prairie State machines, representing as they do the highest development in mechanical devices for artificial incubation, built by skilled mechanics, cannot be sold on a par with the numerous cheal low-priced affairs. And, if the prospective buyer could set the Prairie State product side by side with the low-priced machine, no question would remain as to which is the better value.

\section{Prairie State Incubators Are Built to "Hatch Chicks That Live"}

Real merit always stands out, and it is this quality which las given to Prairie State incubators and brooders the reputation they hare long enjoyed of being the best in the world. Ask any poultry expert-any poultryman who makes poultry-raising his life work-the man who knows, and he will tell you that the Prairie State heads them all.

No. 0 S'TANDARD SERIES SAND 'TRAY INCUBATOR. Price, $\$ 30.00$ f. o. b. Washington. Capacity, 100 hen eggs. Dimensions-Top, 25 by $30 \frac{1}{2}$ inches. Total height, 38 ins. Weight, crated-about 135 pounds. Weight, net-about S7 pounds. Equipment-1 galvanized hardware cloth egg tray, 1 thermometer, tested and mounted; 1 egg tester, 2 non-roll slats, 1 removable burlap mat, extra wicks, onepiece seamless lamp, galvanized sand tray, operating directions-ererything complete, ready to run, except the eggs and oil.

No. I STANDARD SERIES SAND TRAY INCUBATOR. Price, \$37.50. Capacity, $\mathbf{1 5 0}$ hen eggs, 115 duck eggs. Dimensions-Top, 29 by 34 inches, 17 inches deep. Total height, $39 \frac{1}{2}$ inches. Weight, crated-about 160 pounds. Weight, net-about $10 \mathrm{~s}$ pounds. Equipment-1 galvanized hardware cloth egg tray, 1 thermometer, tested and mounted; 1 egg tester, 2 non-roll slats, 1 removable burlap mat, extra wicks, one-piece seamless lamp, galvanized sand tray, operating directions-everything complete, ready to run, except eggs and oil.

No. 2 STANDARD SERIES SAND TRAY INCUBATOR. Price, crated, \$52.50. Capacity, 240 hen eggs, 200 duck eggs. Dimensious-Top, 38 by $40 \mathrm{t} / 2$ inches; $20 \mathrm{1} / 2$ inches deep. Total height, 42 inches. Weight. clated-about $2 \pm 0$ jounds. WVeight, net-about 175 pounds. Equijment-2 salvanized hardware cloth egg trays, 2 thelmometers. mounted and tested; 1 egg tester, 4 nom-roll slats, 2 lemovable burlap mats, extra wicks, one-piece seamless lamp, 2 galvanized sand trays, operating directions-ererything complete, rearly to run, except eggs and oil.

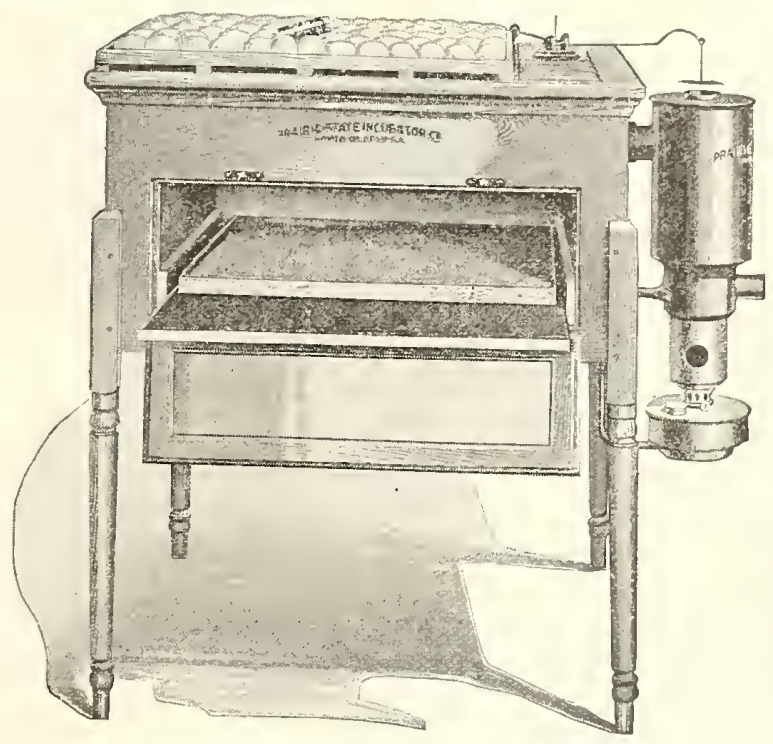

No. 3 STANDARD SERIES SAND TRAY INCUBATOR. Price, crated, $\$ 67.50$. Capacity, 390 hen eggs, 300 duck eggs. Dimensions-Top, 48 by $45 \frac{1}{2}$ inches; $201 / 2$ inches deep. Total height, 42 inches. Weight, crated-about 275 pounds. Weight, net-about 220 pounds. Equipment2 galvanized hardware cloth egg trays, 2 thelmometers. mounted and tested; 1 egg tester, 4 non-roll slats, 2 removable burlap mats, extra wicks, one-piece seamless lamp, 2 galvanized sand trays, operating directions-everything complete, ready to run, except eggs and oil.

Cypress Case. The outer case is of cypress, known as the wood everlasting. The particular wood employed in constructing an incubator case has no bearing upon the hatching qualities of the machine. We have selected cypress at a considerahle cost to ourselves over other woods because it is the most durable under all possible atmospheric or climatic conditions, and because it takes so well the beatiful natural-wood finish characteristic of Praire State incubators.

The inner case, or egg-chamber, is constructed of thoroughly seasoned soft wood, such as pine or poplar, all joints being tongued and grooved.

No sleet steel enters into the Prairie State case. A satis factory sheet-steel case might be made, but if properly constructed would necessitate a much higher price.

Nor do we resort to inferior substitutes. such as pasteboard, burlap, oil cloth or combination board. Such materials cannot last under the varying conditions of incubator use. 


\section{Home Hover}

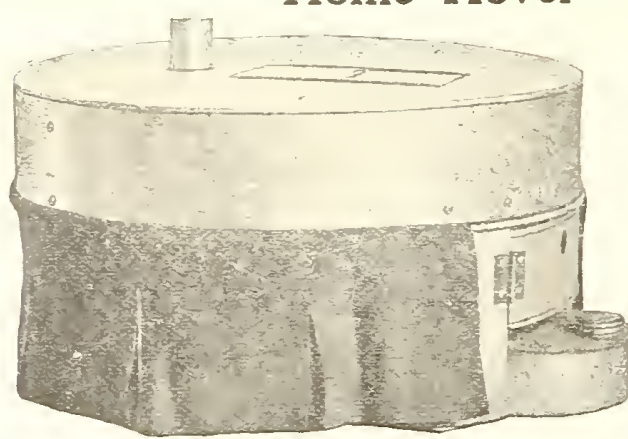

Families har. ing hatches of 40 to 50 chicks need a Ifoorer that will care for their chicks. $\mathrm{k}$ e e p them in good condition: it must be light easils attended in operation. We recommend this Hoover because we have sold it for years with satisfaction, and because it is made by the best incubator people in this countrs. We beliere: lom in price, easily handled to clean, and positive in action.

If youl are going to raise chicks, get one of these.

$50=$ chick size .

$\$ 5.50$

\section{Reliable Standard Incubator}

BOTH HOT AIR AND HOT WATER

Double wall, double heating srstem, nurs ert beneath egg tras genuine copper tanks in hot water styles. Terr best grade of lumbel, finished in natural color with three coats of filler and rarnish. Prices include all fixtures to complete machine.

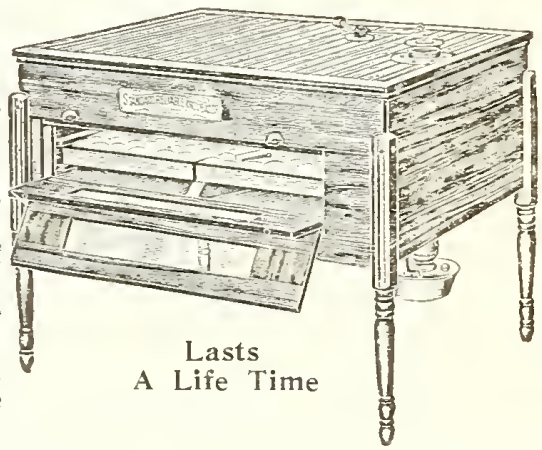

No. 49A-100 Egg, Hot Air ............\$22.50

No, 50 A-100 Egg, Hot Water ............. 28.00

No.51- 140 Egg, Hot Air .............. 31.00

Vo. 52- 140 Egg. Hot Water ............ 37.00

No. 33- 240 Egg, Hot Air ............. 43.00

No. 54- 240 Egg, Hot Water ............ 51.50

No. 55 - 350 Egg, Hot Air .............. 51.00

No. 56- 350 Eror, Hot Water ........... 63.00

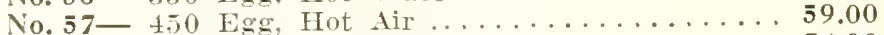

No. 58- 450 Egr, Hot Water ............. 74.00

No. 77-6.80 Erg, Hot Air.......... 98.00

No. 78-6s0 Egs, Hot Water ........... 122.00

No. 79-1100 Egg, Hot Air ..............155.00

No. $80-1100$ Egg, Hot Tater .............. 195.00

\section{Reliable Junior Incubator}

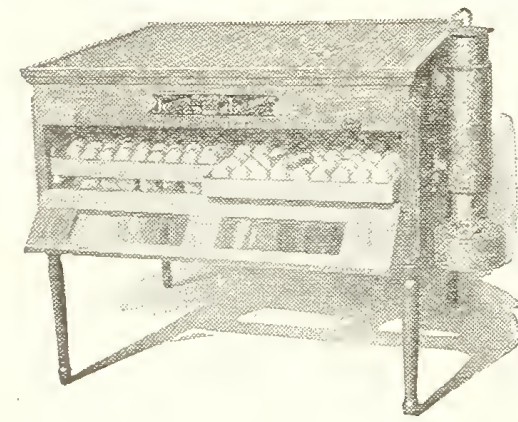

\section{BOTH HOT AIR AND HOT WATER}

Single wall, double heating system with heater outsicle. Genuine copper tanks in hot water styles. Finished same as Stand= ard Machines. A good hatcher at a relp reasonable price. Prices include all fixtures to make machine complete.

No. 81 - 70 Egg. Hot Air ...... $\$ \mathbf{1 5 . 5 0}$

No. 82- 60 Egg, Hot Water ............. 17.00

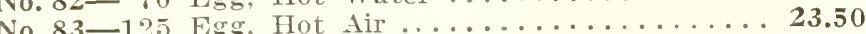

No. 84-125 Erg, Hot Water .............. 28.00

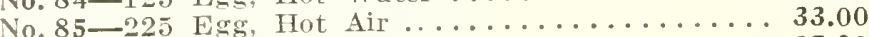

No. 86 -225 Egg, Hot Water ............. 37.00

\section{Reliable Blue Flame Wickless, Oil Heated Colony Hover}

\section{POSITIVE OIL LEVEL \\ SOME OF THE PRINCIPAL FEATURES: \\ Valveless- No \\ Clogging or \\ Stopping of \\ Oil Flow.}

Burns Kerosene

Steady Blue Flame

Comfortable and Easy to Operate

Economy of Operation

Simple in Construction No Overflowing of Burner

No Oil Fumes

Works On an Oil Level

No Wick to Trin

Abundance of Heat

Convenient and Safe

No Coal, Smoke or Gas

There is nothing to wear out or break in this hover. You can fill the hover to full capacity or you can brood as fem as you like, with equal success, and with less work and trouble. case rith the coal store.

We furnish a one-gallon self-feeder glass oil container with our 30, 42 and 52 -inch Horers and a $1 / 2$-gallon galvanized stee oil can with our 22-inch Hovers, so that you need have no fear of light going out, for it is simple and requires very little attention. Burns lierosene or coal oil. Fou can almays get either of these, but it is difficult to get hard coal and then only at an exorbitant price. There is no dirt from coal. no ashes to remove, no noise pouring coal in stove to disturb or scare the chicks.

These Hovers are shipped crated compact with everything complete ready to operate and with full instructions without extra cost. The carry a large stock of all sizes, and will give your order our prompt attention.

$\begin{array}{rcrrr} & \text { Size } & \text { Heater } & \text { Canops } & \text { Complete } \\ \text { No. } & \text { Horel. } & \text { Onls. } & \text { Onls. } & \text { Horer. } \\ 00 & \mathbf{2 2} \text { inch } & \$ \mathbf{7 . 2 5} & \$ \mathbf{3 . 1 5} & \$ \mathbf{1 0 . 0 0} \\ 0 & \mathbf{3 0} \text { inch } & \mathbf{1 0 . 5 0} & 8.45 & \mathbf{1 7 . 5 0} \\ \mathbf{1} & \mathbf{4 2} \text { inch } & \mathbf{1 1 . 8 0} & \mathbf{1 0 . 4 0} & \mathbf{1 8 . 5 0} \\ \mathbf{2} & \mathbf{5 2} \text { inch } & \mathbf{1 3 . 3 5} & \mathbf{1 4 . 3 5} & \mathbf{2 1 . 5 0}\end{array}$

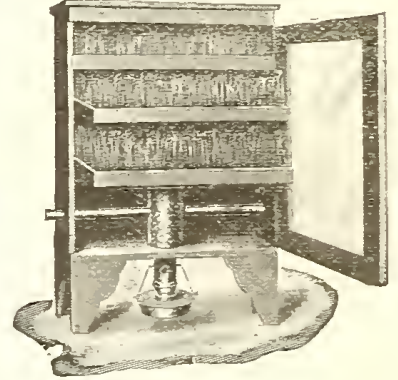

\section{Collins Oat Sprouter}

Sprouted oats are positicely the best and cheapest green food.

This Oat Sprouter will supply green food for 150 hens.

It is no longer necessary for the manufacturer of an Oat Sprouter to urge the feeding of sprouted oats, hecause sprouted oats are recognized as the only practical, sensible and effectire was of furnishing poultry the green feed the must have if they are to lay prolifically during the winter.

Made of galranized iron and will last for years.

Nests in Corrugated Boxes 4 Inches High

8 Pans-11x15, the Popular Size. Weight 14 lbs....\$4.00 5 Pans-11x15, small back jard size. Wgt. 9 lbs... 3.00 8 Pans-11x32, for BIG Business. Wgt. 2S lbs...... 8.00 


\section{BUCKEYE INCUBATORS}

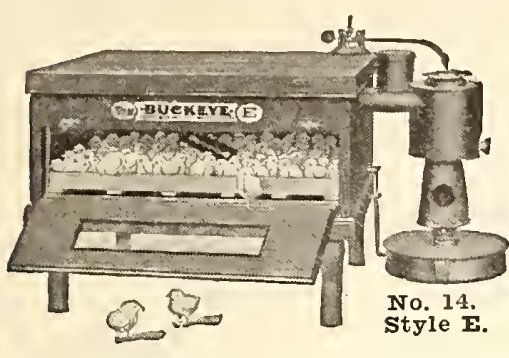

Weight, c r a t e d for shipment, $55 \mathrm{lbs}$.

Capacity, 60 eggs.

Price, $\$ 16.50$.

No. 14 is especially atapted for use by the small raiscr. It has all the important features of the larger machines, such as the visible thermometer, and the Buckeye heating and ventilating system. The temperature is easily regulated and the consumption of oil is low.

No. 16, Style E. Capacity 110 eggs. Weight, crated for shipment, 85 lbs. Price, $\mathbf{\$ 2 7 . 5 0}$. This machine is the same as No. 14, except that it has a greater egg capacity and long

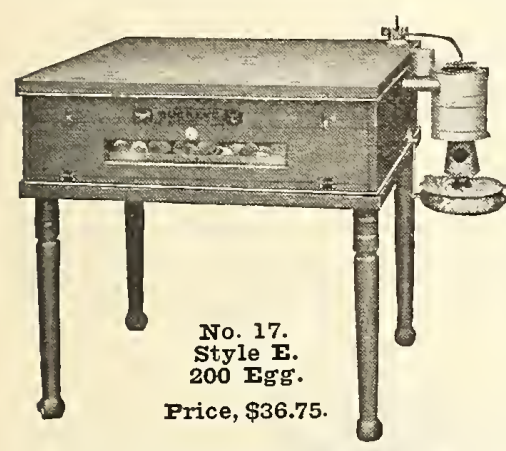
legs instead of $\mathrm{s} \mathrm{hort}$ ones.

No. 17, Style E. Capacity 200 cggs. Weight. crated for shipment, 125 lbs. Price, \$36.75. Same as No. 16, except that it has greater egg capacity.

All Style E incubators have single walls and are equipped with galvanized rust-resisting heaters.
No. 1 Standard has a capacity of 100 hen eggs or 80 duck eggs. Equipped with oil or gas heater, is complete in evcry detail and ready for immediate use. The weight, crated for shipment, is 100 lbs. ' $\mathrm{l}$ his incubator is insurable and bears the Underwriters' label, An improved feature of all Standard incubators is the enclosed lamp.

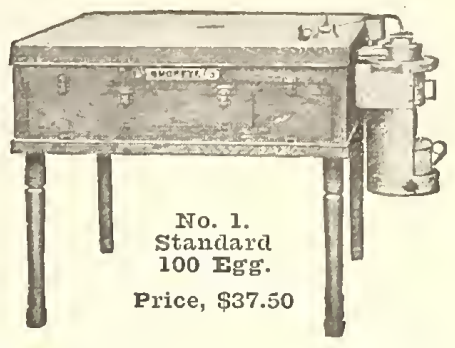
Equipped with oil or gas heater.

No. 2 Standard has a capacity of 175 hen eggs or 140 duck eggs, is equipped with oil or gas heater, and is complete and ready for use. Weight, crated for shipment, 135 pounds. This machine is insurable and bears the Underwriters' label. Price, $\$ 44.50$.

No. 3 Standard has a capacity of 250 hen eggs or 200 duck eggs, is equipped with oil or gas heater and is complete and ready for use. Weight, crated for shipment, 200 pounds. This machine is insurable and bears the Underwriters' iabel. Price, \$57.75.

No. 4 Standard has a capacity of 350 hen eggs or 280 duck eggs. Equipped with oil or gas heater and is ready for use. Weight, crated for shipment, $230 \mathrm{lbs}$. Insurable and bears Undcrwiters' label. This machine is very convenient for the commercial raiser. Price, $\$ 68.00$.

No. 5 Standard (Mammoth Standard). Capacity 600 hen eggs or 480 duck eggs. Outside dimensions-54 ins. square, 36 ins. high. Equipped with four egg trays, holding 150 eggs each. Double doors on front and back; oil or gas heater. Complete and ready for use. Bears Underwriters' label. Weight, crated for shipment, $325 \mathrm{lbs}$. Price, $\$ \mathbf{1 0 7 . 0 0}$.

\section{The Standard Colony Brooder}

The Staudard Colony Brooder will successfully brood $10 \mathrm{U}$ chicks or 1,000. It is the simplest, safest and most economical brooder on the market. It cuts the cost of labor in

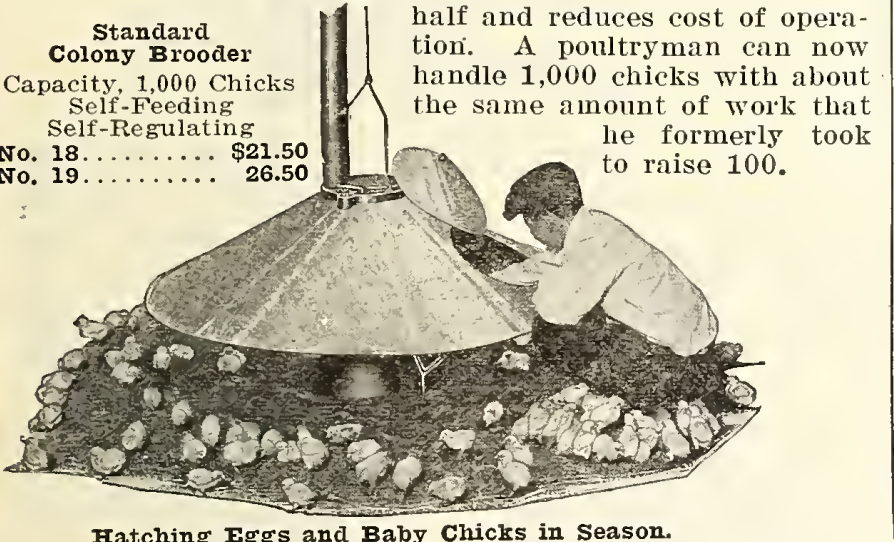

Burns Any Kind of Fuel. The Standard Colony will buru any kind of fuel-hard or soft coal, coke, charcoal, briquettes, or gas. It is self-regulating. You simply have to adjust the regulator at the beginning of the brooding season, and then forget about it. It is self-feeding. You fill the stove once a day and then no further attention is required, as the fuel automatically feeds the fire until it is entirely burned out. It is guaranteed to burn more than 24 hours in any kind of weather.

Can Be Operated Anywhere. No room is too large or too small for a Standard Colony Brooder.

Absolutely Fire=Proof. It is guaranteed to be fire-proof, and will not increase the cost of insurance.

\section{Newton Colony Brooder}

The Newton is the original Coal-burning, Self-feeding, Self-regulating Colony Brooder-the machine which actually levolutionized poultry raising-which has been imitated but never equalled.
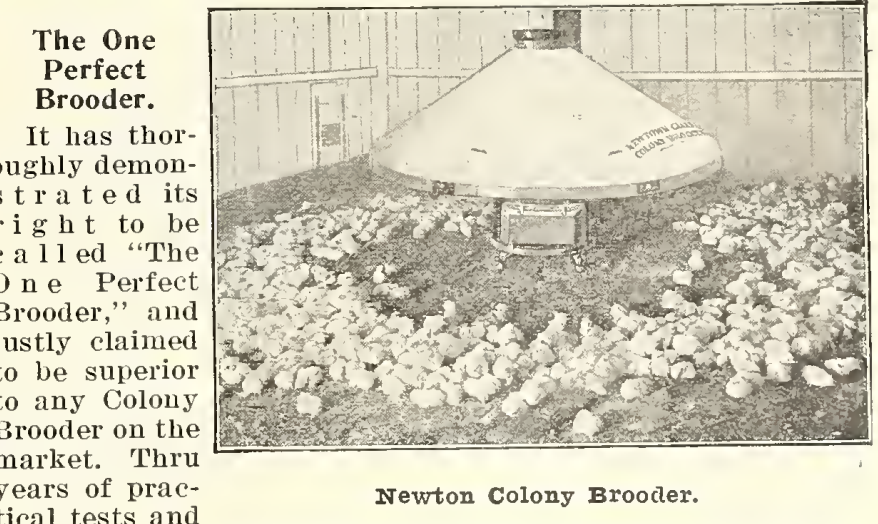
tical tests and

use under all conditions it has been brought to a point of perfection in the details of construction. The Newton is not an experiment-it has made good. The purchaser of this time-tested Brooder runs no risk; he knows it will give satisfaction. More Newtowns are in successful operation than all other makes of coal-burning Colony Brooders combined. Made in three sizes.

No. 6...\$22.50 No. 7...\$25.00 No. 11 .

$\$ 32.50$

The Newtown Giant Incubator is recognized by all leading chicken growers as the best for big work. They are so much in demand that orders have to be taken at least 40 days ahead of delivery time. Capacity, 1,200 to 2,400 eggs.

Prices on application. 


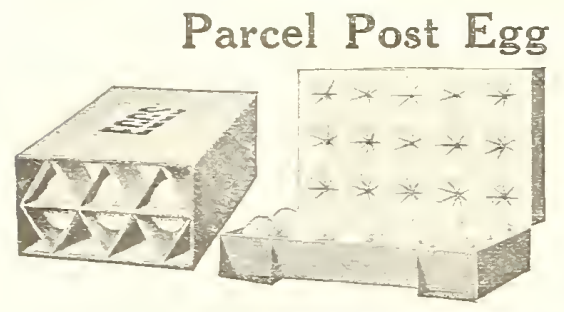

Boxes

of Heavy Cardboard Most practical way of shipping eggs.

Boxes holding 1 dozen.....25 cts. 2 dozen.....40 cts. 3 dozen....50 cts. 4 dozen....60 cts.

\section{Wire Nests}

These nests are made of heary coppered wire, fully braced and will hold their shape longer than other nests on the market. Price, 35 cts.

\section{Chalk Nest Eggs}

Per dozen

\section{Feed and Water Cups}

Made of galranized iron to be hung on coops. 1 =pint, $25 \mathrm{cts}$.; 1 =quart, $30 \mathrm{cts}$.

\section{Dry Mash Hopper}

Will not waste the feed. Cannot clog. being wider at bottom than top. Curred bottom throws last bit of feed to front. Four sizes:

No. 1- 9 inches.

$\$ 1.75$

No. 3-24 inches....\$2.50

No. 2-15 inches.

2.25

No. $4-36$ inches.

3.75

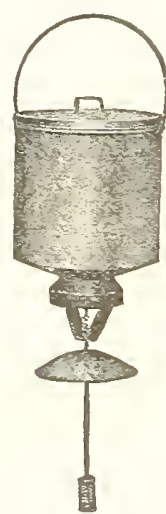

\section{O. K. Exerciser Feeder}

The O. K. Exerciser Feeder is one of our leaders, as it is exceptional ralue for the price. The hopper (holding 12 quarts) is made of No. 28 galranized steel, and is reinforced with a double thickness around the top. The ball is hears galranized rod so that the weight of the grain does not spring it out of shape.

The pendulum rod and grain distribntors have the accurate adjustment with two brass nnts, and the convenient separable construction, which are patented features of our Economy Exerciser.

The O. K. Exerciser is perfectly weatherproof: and will compare farorabls with ans exerciser erer sold at less than two dollars.

Capacity, 12 qnarts. Price, $\$ \mathbf{1 . 5 0 .}$

\section{The Peerless Fountain}

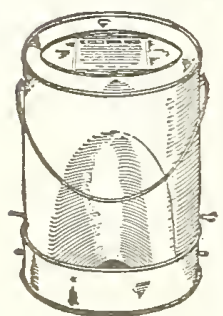

The Peerless is the all-right fount. The water is alwars pure: it is protected from dirt and filth. The fowls cannot injnre their combs while drinking: eass to fill and easy to clean.

$1=$ quart

10 =quart .............. 1.25

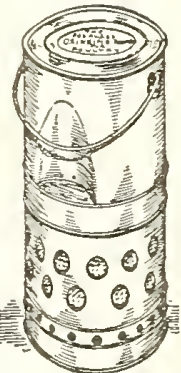

PEERLESS FOUNTAIN HEATERS

\section{(6)}

Incubator and Brooder Thermometers

Incubator Thermometers ............... .75

Wire Stand for same...................15

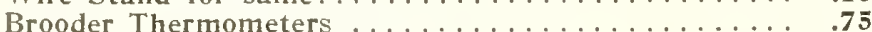

Moisture Gage for Incubators............... 3.00

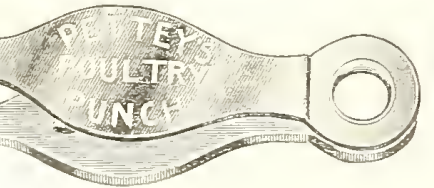

It is perfectly safe to mark chicks with this Pnnch soon as hatched. Mark them all and know their age.

Price

\section{Aluminized Metal Egg Crates}

Solve the problem of shipping eggs, bntter and other farm prodncts by Parcel Post. They are made for continned nse. being strongly constructed, but light in weight.

All crates are providied with built-in shock absorbers to gire a cnshion for the eggs. Fillers to hold the eggs are made for a long life.

Metal Egg Crates do not regnire any outside wrapping for mailing. A short string only is needed for tying "pin" which holds lid securely closed.

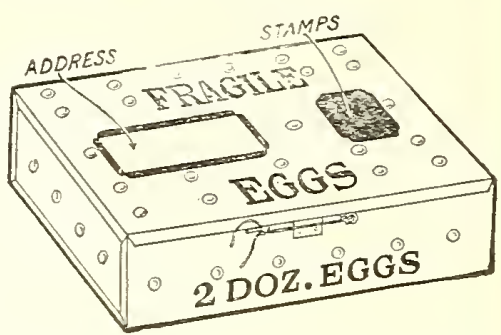

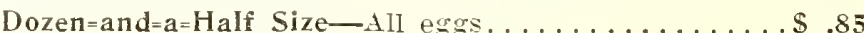
Two=Dozen Size-All eggs................ 1.00 Three=Dozen Size — All eggs.............. 1.25 Four=Dozen Size-All eggs................ 1.50

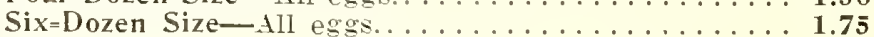

\section{Combination Crates}

\section{WITH CONTAINERS}

No. $1-7$ Ibs, and 2 doz. eggs.............\$1.75

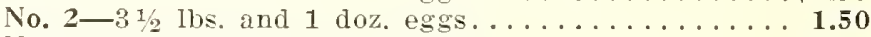
No. 3-31\% Ibs. and 2 doz. eges.............. $\mathbf{1 . 6 5}$ No. $4-3$ 1/2 Ibs. and 3 doz. eg. $. \ldots \ldots \ldots \ldots \ldots \ldots \ldots . \ldots \ldots$ No. $4 x / 2-1$ Ib. and 1 doz. eggs.................. Add postage for 2 lbs. to destination.

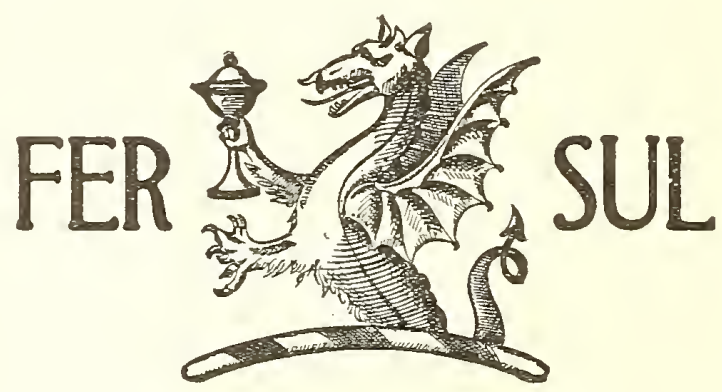

A commercial disinfectant and antiseptic that is non-poisonous, odorless and at the same time a tonic is a noreltr. For these reasons, if for no others, FER-SUL merits yon inrestigation. FER-SUL kills most bacteria and germs when bronght in contact with them and nentralizes most pntrescent odors; it also destrors certain weaker forms of rermin.

As FER-SUL bas no odor it cannot injure dairy products with its smell.

For a genelal cleaning up of unsanitars conditions or the remoring of ordinars barnyard odors, a liberal sprasing of a $5 \%$ solution (1 pint of "FER-SUL" to 20 pints of water) will effect the desired result. If the conditions are offensive or if disease has broken ont among horses. cattle or swine. use, at first, a $10 \%$ solntion ( 1 pint of "FER-SUL" to 10 pints of water), and repeat daily with $5 \%$ solution.

FER-SUL, being a liquid, is adapted, naturally, for spraying or sprinkling. It should be used regularly and liberally in the dairy and on poultry farms, and in all barns, stables. pigstrs, coops, cesspools, priries, or, in fact, wherever contagion is liliely to lurk. When used as directed, no fear need be felt from the after-effects.

FER-SUL has two rers marked properties: One, that of a germicide, and the other a tonic. One actire in killing disease, the other in restoring health. Detailed instructions for its use in the specific troubles or maladies we hare investigated, can be obtained by postal request. 12 ozs., 78 cts.; quart, $\$ 1.30 ;$ gallon, $\$ 3.12$. 


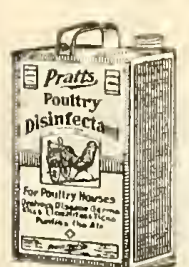

\section{Pratt's Horse and Cattle Remedies}

Animal Regulator...........26c and 52c Horse and Cattle Condition Powder.26c and 52c Healing Ointment, box............26c Healing Powder, box............26c

\section{Pratt's Food and Remedies}

Poultry Regulator .........26c and 52c Poultry Regulator........12=lb. bag, $\$ 1.35$ Powdered Lice Killer. .......26c and 52c Head Lice Ointment . . . . . . . . . . .32c Liquid Lice Killer......qt. 50c; 1/2 gal. 85c; gallon, $\$ 1.50$ Red Mite Special............... $65 \mathrm{c}$

\section{Whiting's Roupene}

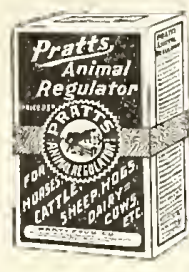

A positive preventive and cure for roup, canker, diphtheria, chicken pox, gapes, colds and all diseases of the respiratory organs in fowl and pigeons.

When roupy symptoms are first discovered a dose or two of Roupene will kill all trace of the disease. Per bottle, 52 cts.

\section{Whiting's W. D. Remedy}

Will absolutely destroy the White Diarrhoca germ. It will cure the trouble and stop spread of disease. Per bottle, 52 cts.

\section{Germozone}

A little Germozone in the drinking water will positively cure and prevent bowel trouble of any kind, except that which is caused by lice, improper food, etc. The cause must be removed if a permanent cure is to be expected. Price, per box, $78 \mathrm{cts}$.

\section{Weak-Nee Well}
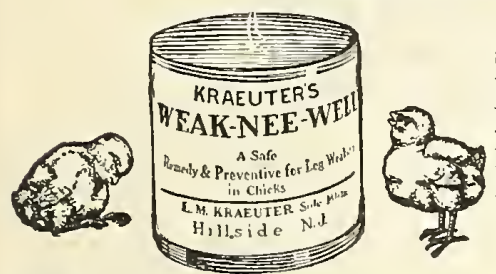

Weak-Nee Well is a life saver for little chicks, as it will positively $\mathrm{cur}$ e lcg weakness. Has never been known to fail. Is used in the feed, so there is no trouble to give it.

Boxes, 32 cts.
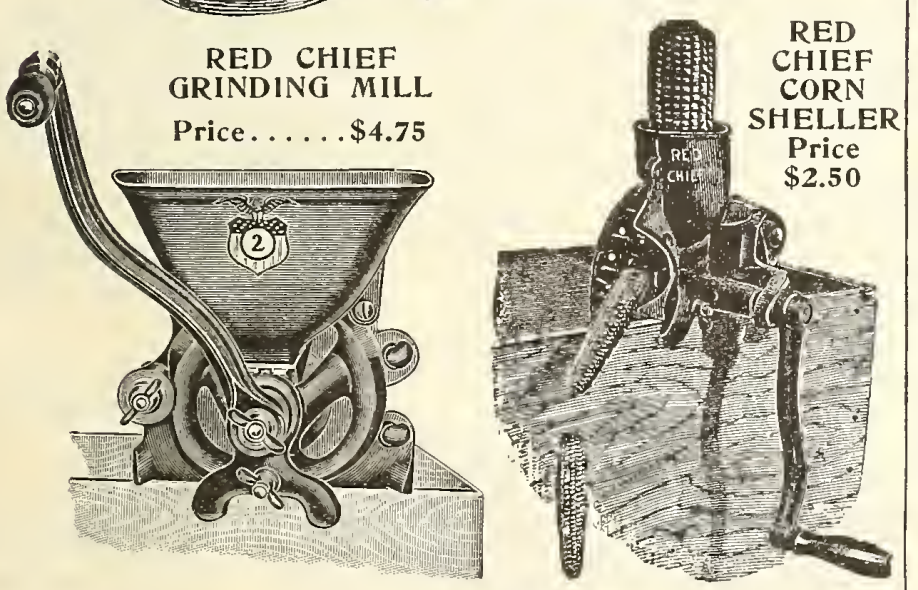

\section{Leg Bands \\ ADJUSTABLE}

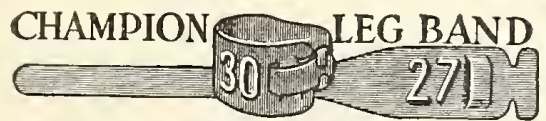

12 for. . . . . . 20 cts.

25 for............

\section{Celluloid Leg Bands}

Made in sizes to fit all brecds, even chicks and pigcons. Eight colors - black, white, blue, dark blue, cherry, red, amber, and green. When ordering state breck aud color wanted.

12 for..........20 cts. 50 for 25 for............ 100 for

$50 \mathrm{cts}$. 85 cts.

\section{Moe's Round Baby Chick Feeder}

The Most

Convenient and

Commodious

Feeder On the Market for the Price.

A great feed s a v e r, as the little $\mathrm{chicks}$ cannot get into it and contaminate $t h$ e fecd. It can also be used for water. This is a practical, well-made feeding de vice that will last for years. Made of the best grade of galvanized iron. Small size, 15 cts.; Large size, 25 cts.

\section{Moe's Star Jar Fountain and Feeder}

No parts to come unsoldered. Leaking impossible. Will fit pint, quart ol half-gallon Mason jar. Convenient, cheap and sanitary. One size only. Price, $10 \mathrm{cts}$.

\section{Dry Bone and"臀 Shell Mills}

Made for grinding dry bones, shells, grain and many other substances for poultry. Can also be
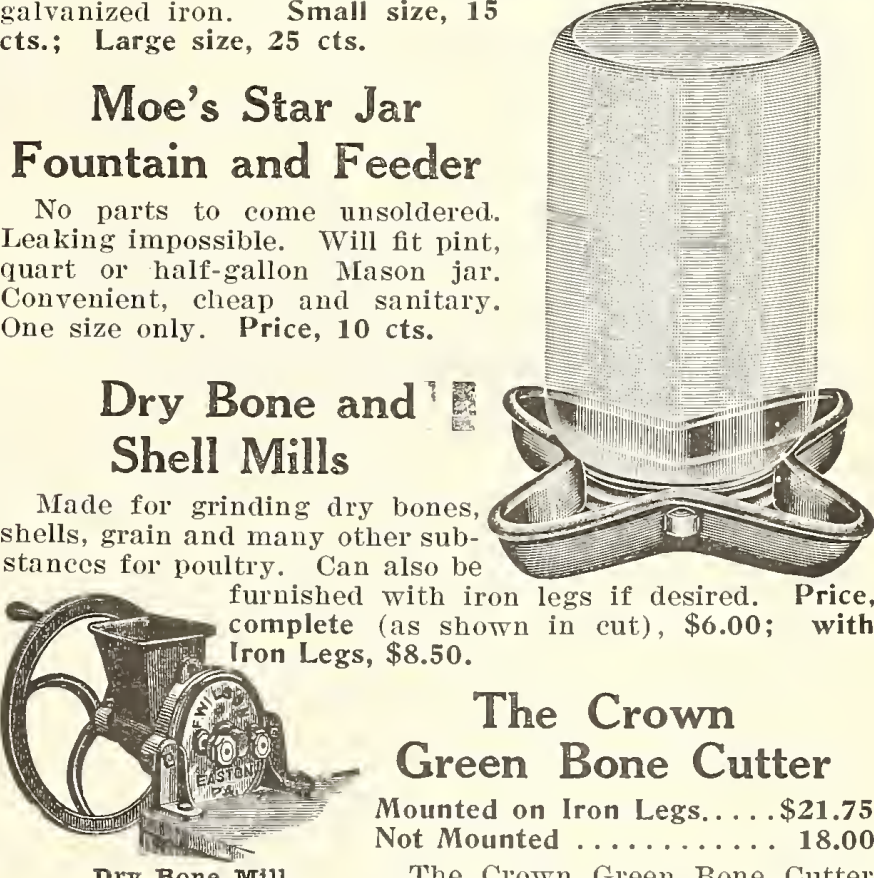

(1)
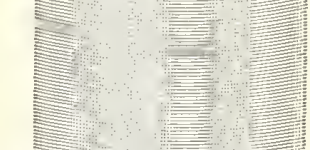

\section{The Crown Green Bone Cutter}

Mounted on Iron Legs.....\$21.75 Not Mounted ......... 18.00

The Crown Green Bone Cutter surpasses all others in easy and rapid cutting. They feed automatically and leave both hands free to operate; the feed regulates the power requiled so that it cannot run hard. The feed screw is large and has a coarse thread that will not wear out nor crush down nor break. The gears are guarded so that they cannot clog. The cylinder has been enlarged so they can take in a good size bone. They have adjustable steel knives; they are strongly built, and will not break or wear out.

\section{Egg=O-Latum}

Egg-O-Latum is a soft, white, preservative wax. First applied to the palms of your hands to warm and soften the Egg-OLatum-then rubbed on the eggs. A dozen per minute can be handled in this way. Green Bone Mrill. Do not wash the eggs. Egg-O-Latum keeps indefinitely. Two sizes, For 50 doz, eggs, 50 cts.; for 200 doz. eggs, \$1. 


\section{The Star Poultry and Live Stock Remedies and Poultry Foods}

\section{FOR POULTRY}

STAR=CHIC $=A$ is a complete food for the chick from the time of hatching until it is readr to take care of itself. Water, grit and charcoal is all that are needed when STAPCHIC-A is used as a food. $1=1 \mathrm{~b}$. pkg. $10 \mathrm{cts}$. (by mail 15 cts.); 5 =lb. pkg. 40 cts. (by mai! $60 \mathrm{cts}$.). In bags, $12 \mathrm{r} / 2$ lbs. $90 \mathrm{cts}$.; $25 \mathrm{lbs}$. $\$ 1.60 ; 50$ lbs. $\$ 3.00 ; 100$ lbs. $\$ 5.75$. Post $=$ age extra.

STAR=CALF $=A$ is a body builder for the Baby Calf, and it cannot be too highly recommended to breeders as a whole or partial foori for their calres. The profit comes from feed ing STAR-CALF-A with skimmed milk and there is no wisdom when feeding calves whol milk containing 30 per cent butter fat. When you can raise just as good or better calves with STAR-CALF-A and skinmed milk. 25=lb. bag, $\$ 1.50 ; \quad 50=1 \mathrm{~b}, \mathrm{bag}, \$ 2.75 ; \quad 100=1 \mathrm{~b}$. bag, $\$ 5.00$. Express or freight extra.

Star Roup Powder

Star Blue Powder for Fowl Cholera.

Star Gape Powder

Star White Diarrhoea Tablet.

Star Blackhead Powder Turkey Raiser.

Star Scaly Leg Ointment.

Star Lice Powder

Star Lice Ointment

Star Chicken Pox Treatment.

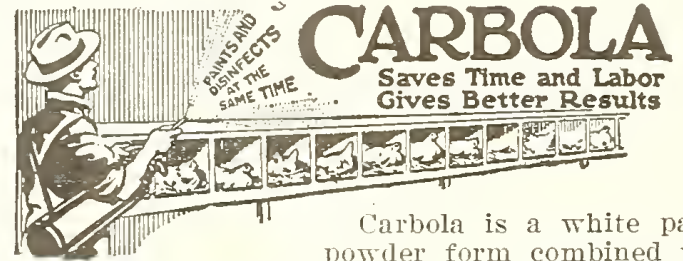

powder form combined with a disinfectant many times stronger than pure carbolic acid. It is non-poisonous and non-caustic. It kills lice, mites, fly eggs, etc., and helps prerent the start and spread of contagious diseases that affect man, beast and fowl. Carbola is two things in one-a paint that disinfects or a disinfect ant that paints. It dries a clear snow white. It saves labor, time and moner. It paints and disinfects at one operation in the same time and with the same labor required to paint or disinfect only.

Carbola is recommended for use instead of whitewash in erery place where whitewash ordinarily is used, and it is recommended for use instead of whitewash and disinfectants in stables. Kennels, poultrs houses. rabbit hutches, barnes, creameries, hog pens. dairs buildings.

It is recommended for use as a disinfectant whererer one is needed and where the added light that comes from a whitened wall- which walls increase the light from 25 per cent to 50 per cent-is an adrantage. Trial pkg. 30 cts.; 10 lbs. $\$ 1.25 ; 50$ lbs. $\$ 5.00$.

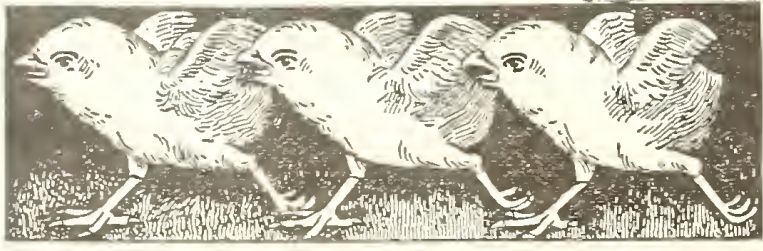

Baby Chicks by Mail THROUGHOUT THE SPRING SEASON

\section{Conkey's Chicken Remedies}

Conkey's Healing Salve .............26c Conkey's Lice Powder ......26c and 52c Conkey's Limber Neck Remedy.........52c Conkey's Roup Remedy ......26c and 52c Conkey's Gape Cure ........26 and $52 c$ Conkey's Lice Killer ..........1 qt., $52 \mathrm{c}$ Conkey's Lice Killer ............. qts., 85 c Conkey's Lice Liquid ...........gal., $\$ 1.25$ Conkey's Poultry Tonic .....26c and 52c Conkey's Laying Tonic .............26c Conkey's Cholera Cure .......26c and 52c Conkey's Chicken Pox Remedy.........52c Conkey's Scaley Leg Remedy.........52c

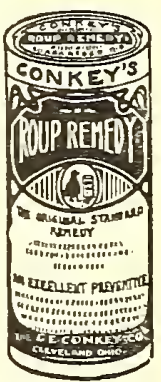

\section{Pratts.}

\section{Buttermilk Baby Chick Food}

The first three weeks is the critical time of a chick's life. They are tender babies and need PRATTS, the original "baby food for baby chicks." It is the right food because it contains only the sweetest and best of wholesome growing food elements that will meet every need of a baby chick.

Dried Buttermilk, cooked wheat, bone-building phosphates - these and a host of other splendid ingredients go to make up PRATTS BUTTERMILK BABY CHICK FOOD. Best because it gives results; cheapest because it raises more and better chicks. Always uniform, sweet, appetizing and satisfying. Used for years by thousands of the most successful poultrymen the world over. Packages 25 and 50 cts. 14 lbs..........\$1.00 50 lbs.........\$3.00 25 Ibs. . 1.60 $100 \mathrm{lbs}$.

5.75

\section{PRATT'S REMEDIES}

ANIMAL REGULATOR............26c and 52c $12=$ lb. pail, $\$ 2.20 ; 25$ lbs. $\$ 3.54$.

HEALING OINTMENT, per box.......... HEALING POIVDER, per box..........32c

POULTRY REGULATOR.......... POULTRY REGULATOR, $12=1 \mathrm{~b}$. bag......\$1.40

POWDERED LICE KILLER.........25c and $50 \mathrm{c}$

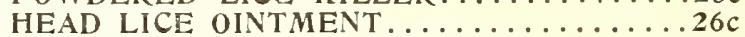

LIQUID LICE KILLER... . Qt. 55c; $\mathrm{r} / 2 \mathrm{gal} .95 \mathrm{c} ;$ gal. $\$ 1.60$ DISINFECTANT.......Qt. 55c; 2 qts. 95c; gal. $\$ 1.60$ ROUP TABLETS................26 and 52c WHITE DIARRHOEA TABLTS..........26 and $52 \mathrm{c}$ GAPE COMPOUND (Internal and ExternaI)..32c and $63 \mathrm{c}$ 


\section{Planet Jr. Farm and Garden Tools}

You cannot afford to till the ground without PLANET JR. TOOLS. They not only save hard labor, but enable you to cultivate double the acreage in the same time, and thus add over 100 per cent to your crop yield. Invented by a practical farmer and manufacturer-the result of fifty years' experience. Strong, lasting construction. Fully guaranteed.

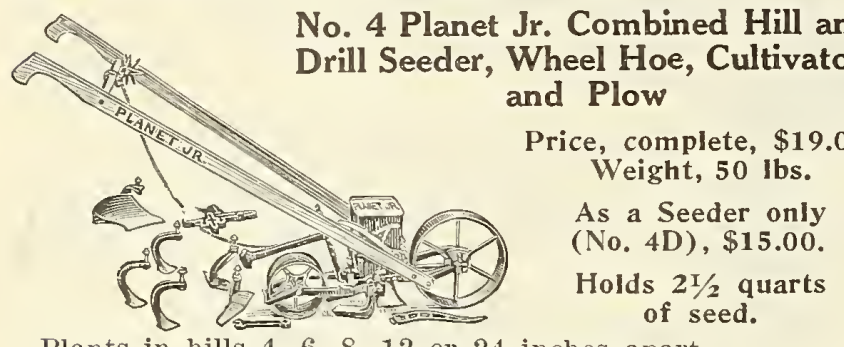

Plants in hills $4,6,8,12$ or 24 inches apart.

Soon pays for itself in the family garden as well as in the larger acreage. Sows all garden seeds (in drills or in hills), plows, opens furrows and cover's them, hoes and cultivates quickly and easily

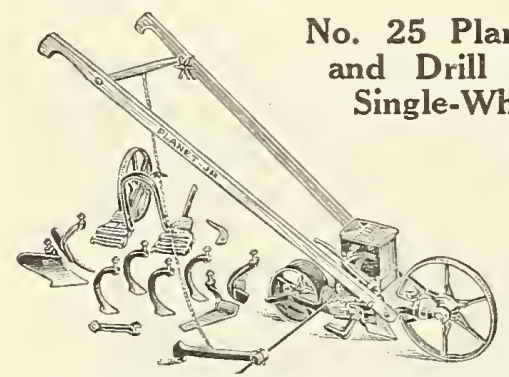

No. 25 Planet Jr. Combined Hill and Drill Seeder, Double and eel Hoe, Cultivator and Plow

Price, \$22.50.

Weight, packed, 61 lbs. Holds $2 \frac{1}{2}$ quarts of seed.

As a Seeder it is practically the same as the Planet Jl. No, 4, and as a Wheel Hoe it has the same steel frames and cultivating attachments as the Planet Jr. No. 12 Double-Wheel Hoe.

Two acres a day can easily be worked, and when it is done it will be a better job than sereral men could have done in the same time with hand hoes.

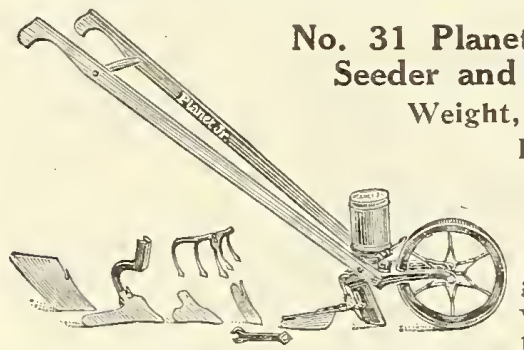

No. 31 Planet Jr. Combined Drill Weight, packed, 30 lbs.

Price, complete, $\$ 13.50$

No. $31 \mathrm{D}$, as a Drill

Seeder only, $\$ 10.00$.

This new tool is of great value to gardeners who have never felt able to own either a s e e d Drill or a Wheel Hoe. It will sow even a small packet of garden seed with great precision. Quickly changed to a splendid Wheel Hoe. A special machine for the small gardener.

No. 33 Single-Wheel Hoe (No. 31 without Seeder) Price, $\$ 6.50$.

No. 3 Planet Jr. Hill and Drill Seeder

Price, $\$ 18.00$.

Holds three quarts of seed. A farorite among onion-growers, ma r k e t gardeners, and seedsmen. Sows accurately in a row making wheel-hoe cultivation easy.

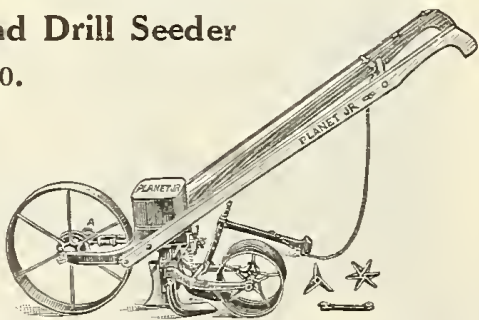

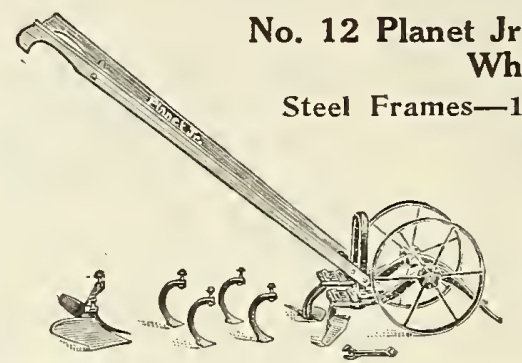
Wheel Hoe f $\mathrm{r}$ a $\mathrm{m}$ es and 14-inch steel wheels. The greatest hand-cultivating tool in the world. The attachments sold with No. 12 are what gardeners use most, and the other's can be added as wanted.

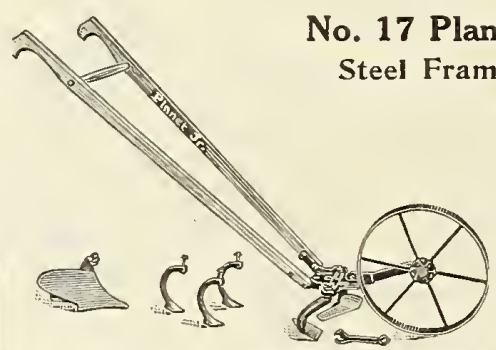

No. 17 Planet Jr. Single-Wheel Hoe

A Single- and DoubleWheel Hoe in one. It straddles crops till 20 ins. high, then works between. Has steel -15-inch Steel Wheel. Price, \$8.25.

The highest type of the Single-Wheel Hoe made. Light but strong, and can be used by man, woman, or boy. Will do all the cultivating in your garden in the easiest, quickest, and best way. These wheel=hoe tools are of a special pattern, carefully tested by practical men; no others ever offered compare with them. All the steel parts are high carbon steel, oil-tempered, finely formed, finished and polished, and work to a charm.

\section{No. 8 Planet Jr. Combined \\ Horse Hoe and Cultivator Price, $\$ 19.00$.}

No other cultivating machine is so widely known as the Planet Jr. Combined Horse $\mathrm{H}$ o e and Cultivator. for this machine is in use throughout the civilized world. It is so strougly built as to withstand incredible strain, yet it is light and easy to handle.

\section{Planet Jr. Twelve-Tooth Harrow Cultivator and Pulverizer}

No. 90 -Price, $\$ 19.50$.

W it h the TwelveTooth Harrow you go as deep or shallow as you like, come up close to row without injuring plants, cut out all weeds, stir the soil and fine it as with a garden rake. You widen and narrow as you please between 12 and 32 inches. A favorite with strawberry-growers, market-gardeners, etc.

No. 90B (less Pulverizer) ..............\$16.25

No. 90D (without Pulverizer or Wheel) ....... 12.50 
The South Bend Chilled Plow STANDARD THROUGH THE WORLD

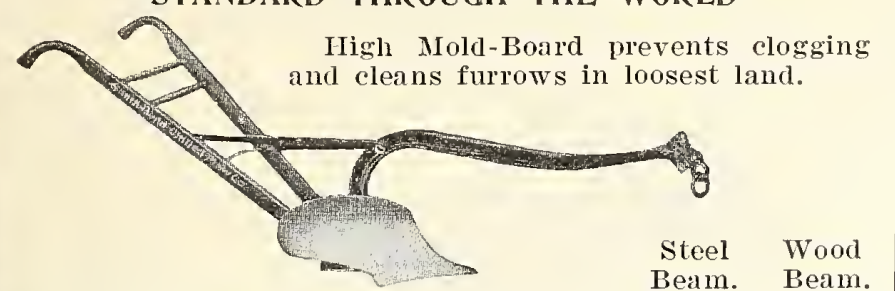

No. 63. One IIorse Plow............\$ 7.00 \$6.50

No. B1. One Horse Plow. . . . . . . . . . . $\mathbf{8 . 0 0} \quad \mathbf{7 . 5 0}$

No. 2. Light Two Horse............. $9.75 \quad 9.25$

No. 21/2. Light Two Horse............. $11.50 \quad 11.00$

No. 3. Medium Two IIorse............ $12.50 \quad 12.25$

No. 4. Regular Two Horse............ $14.25 \quad 14.00$

No. 10. Large Two Horse. . . . . . . . . . $15.50 \quad 15.25$

No. 151. 'Three Horse Cast Iron ........ 15.00

\section{Syracuse Contractors' Plow}

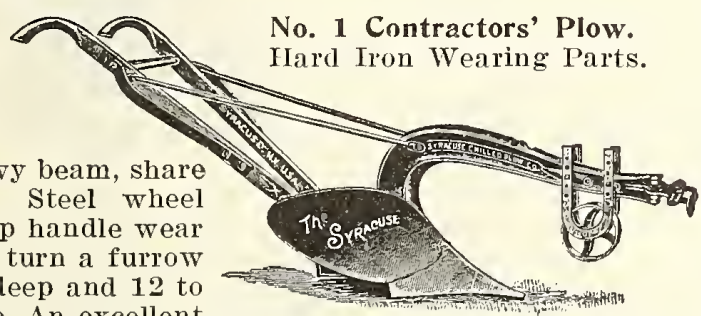

Extra heary beam, share and strip. Steel wheel frame. Loop handle wear irons. Will turn a furrow 5 to 9 ins. deep and 12 to 15 ins. wide. An excellent

Plow for general grading purposes. No. 1 Contractors' 'Two or Four Horse, weight, with wheel, 205 1bs. Price, \$29.00.

No. 99 Syracuse Four to Eight Horse Contractors' Plow. Weight, with sloee, $310 \mathrm{lbs}$. This plow is equipped with a steel truss beam, steel moldboard and landslide, separate shin piece. Heavy overlaid wrought steel share, adjustable shoe in place of wheel. Loop handle wear irons; very slightly built. Price, $\$ 30.00$.

No. 10=1878 Three Horse. Furrow, 6 to $9 \frac{1}{2}$ ins. deep, 14 to 16 ins. wide. Price, $\$ 18.75$.

No. 30=78 Three Horse. Left hand. Price, \$18.75.

No. 1=1878 Large Two Horse Plow. Furrow, 5 to 8 ins. deep, 12 to 15 ins. wide. Price, $\$ 16.50$.

No. 2=1878 Medium Two=Horse Plow. Furrows, 5 to $7 \mathrm{1} / 2$ ins. deep, 10 to $13 \mathrm{ins}$. wide. Price, \$15.00.

No. 3=1878 Light Two Horse Plow. Furrows, 4 to 6 ins. deep, 9 to 12 ins. wide. Price, \$14.00.

No. 7 Medium Two Horse. Furrow, 5 to 7 ins. deep, 10 to 13 ins. wide. Price, $\$ 16.00$.

\section{The New Deere Balance Tongue Walking Cultivator}

No. D. D. 161.

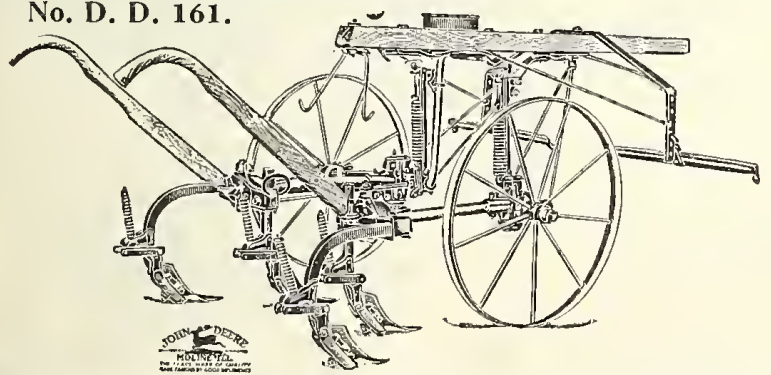

Pipe beam, parallel, 4 shovels, spring trip, and spring lifting device. The tongue is perfectly balanced on the wheels with no support at front or rear. The lifting-spring device is the simplest and the most satisfactory spring that has ever been attached to a walking cultivator. Price, \$42.00.

\section{Wiard Road or Contractors' Plows}

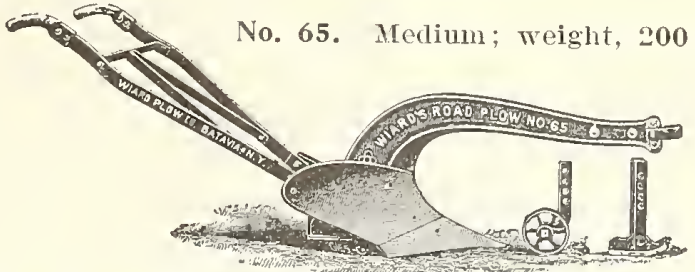

The cut iliustrates the No. 65 Plow, which is very substantial, and is heavy enough for ordinary road or contractors' work when used with 2 or 4 horses.

A Cast Iron Point, made from the best quality of char. coal iron, very strong and heavy.

Price, with Wheel or Shoe.

Price, without Wheel or Shoe............. 24.50

Extra for Forged Steel Point................ 6.50

\section{Wiard Pavement or Rooter Plow}

No. 67. Four or Six Horse; weight, with clevis, 250 lbs. This Plow has great strength and is adapted to contractors work and for tearing up cobblestone or McAdam pavements.

The Beam is made of charcoal cast iron, very strong and heavy. The tendency to wear off the lower front end of the Bean in this class of Plows is entirely overcome by a separate shoe casting attached to the beams at this point, which can be replaced at slight expense when worn.

'The handles are made of steel, strongly braced, being a new departure, as heretofore handles for this style of Plow have been made of wood and were easily broken.

Price, $\$ 40.00$.

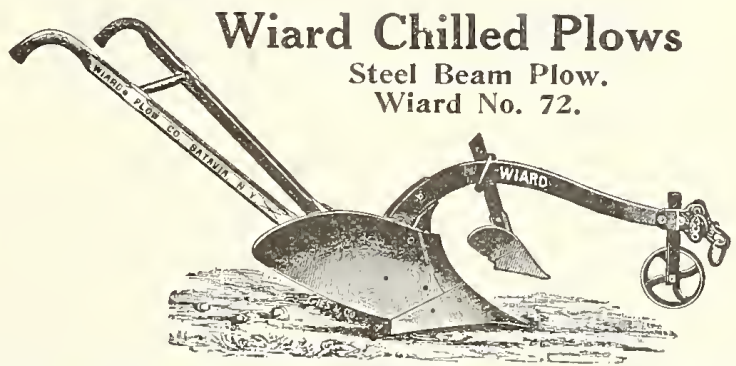

The Wiard Plow has been made without lapse since 1804 , and hence the Wiard Plow Works have the prestige of being the oldest continuous manufactory of Plows in America, and, so far as known, the oldest on the globe.

No. 62. One Horse Wood Beam.............\$ 6.50

No. 13. One Horse Wood Beam............ 8.75

No. 10. One Horse Wood Beam.............. 11.00

No. 19. Light Two Horse Wood Beam.......... 14.50

No. 16. Medium Two Horse Wood Bean.......... 15.50

No. 73. Light 'Two Horse Steel Beam........... $\mathbf{1 3 . 5 0}$

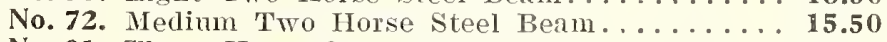

No. 91. Three IIorse Steel Beam............ 16.50

\section{Oliver Pattern Plow \\ RIGHT AND LEFT HAND}

Full Line of One, Two and Three Horse Plows

Steel Wood

Beam. Beam.

No. A. One IIorse Oliver Pattern....... - \$ 7.25

No. B. One Horse Oliver Pattern...... $\quad 8.00$

No. 10. One Horse Oliver Pattern........ - 9.75

No. 13. One Horse Óliver Pattern....... 11.00

No. 19. Two Horse Oliver Pattern.......\$13.50 12.50

No. 20. Two Horse Oliver Pattern........ $14.50 \quad \mathbf{1 3 . 7 5}$

No. 40. Three Horse Oliver Pattern....... 16.50 15.75

ALL PRICES SUBJECT TO CHANGE WITHOUT NOTICE 


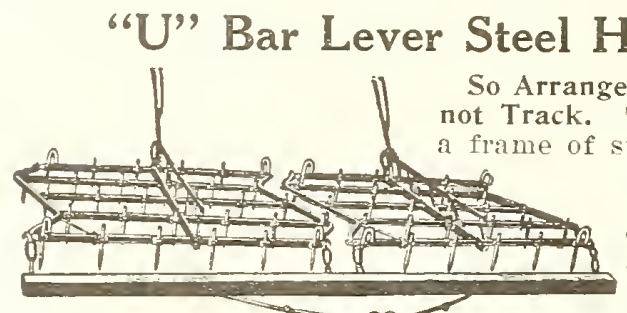

Harrow

gires the Harrom a double adrantage. strength and rigidity, and is a suaro against catching into trees and stumps. The teeth can be set to any pitch or cut desired.

Price: $25=$ Tooth, $\$ 8.50 ; \quad 50=$ Tooth, $\$ 17.00$.

\section{Wood Frame Scotch Harrows}

These Harrows Are Made in Three Sizes

24=Tooth, one horse. \$9.25 40=Tooth, two horse. $\$ 16.75$

The one horse sizes are in one section and equipped with steel runners. Which enable one to transport the Harrow from one field to the other without tearing up the grass. The 40-inch is made in two sections, and can be folded.

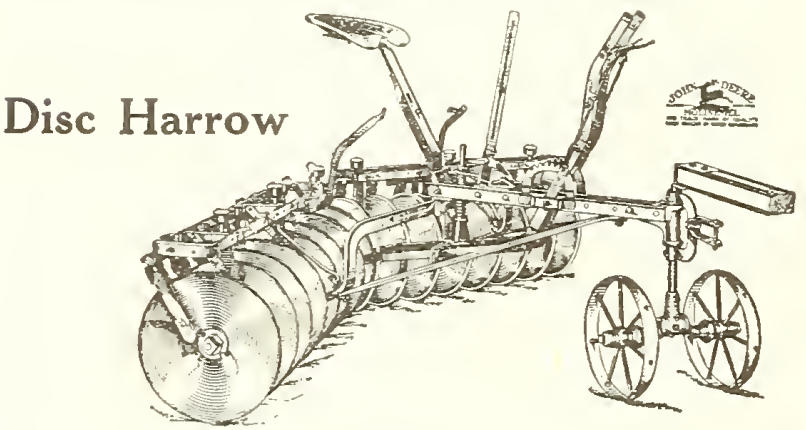

The time is long past when a farmer or market gardener can do without a Disc Harrow. When rour ground is weedr and lumpy, then is the time when you need and want a Disc Hariow. Our Disc Harrows are strong, set not too hears; eas 5 on horse and man; sares labor-that means, sares monev: does the Work better than it is possible to do it with a plow or any other harrow. Eight 16-inch discs, \$45.00; Ten 16-inch discs, $\$ 50.00$; Twelve 16 =inch discs, $\$ 54.00$.

The above prices include Truck, but withont Tongue. If Tongue is wanted instead of Truck, deduct $\$ 6.50$.

\section{Syracuse Spring Tooth Harrows}

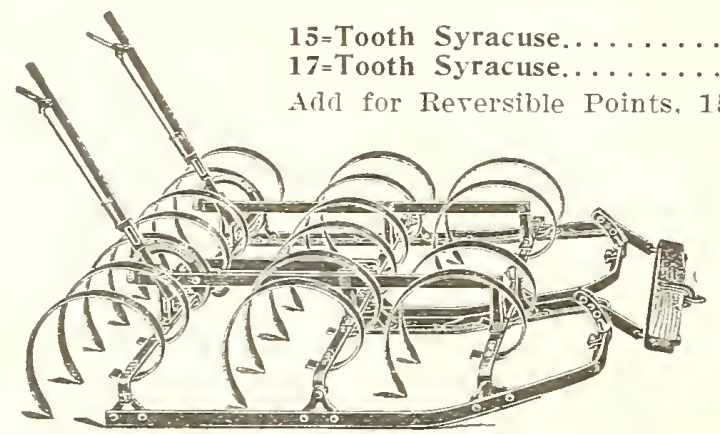

\section{Wheel Barrows}

No. 1. Buch's Large Size. $\$ 8.50$

No. 3. Medium Size..... 7.00

No. 8. Wooden Tray, with

Steel Wheel..... 5.00

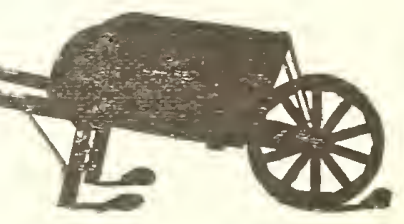

\section{John Deere Double Row Corn Planter}

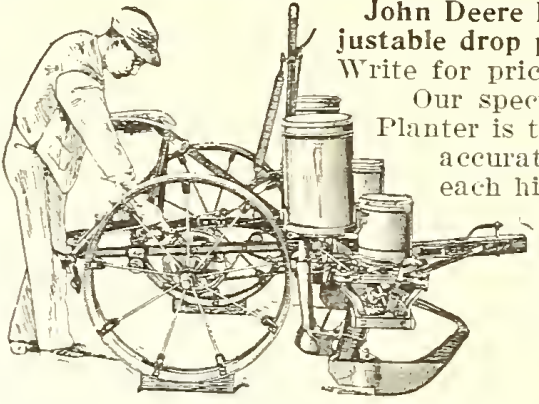

lanters fitted with ad= iustable drop plates when so ordered. e for prices.

Our special new feature in this cecurate number of kernels in ach hill, but we get the num. ber of kermels in each hill which the quality of the soil is able to bring to perfect ma. turity.

Price, \$83.00, Complete.

\section{Improved Robbins Potato Planter}

Price, with Fertilizer Attachment, $\$ 100.00$, complete.

The onls $100 \%$ Potato Planter.

Four stples of furrow opening fomar.

plows are made - - ou in each case the soil is left loose on each side of the furrow-no packing. The four strles are: $\mathrm{Sh}$ i e I d Opening Plow, Single Dise Open-

ing Plow, Double Disc Opening

Plow, and Wing shield Opening Plow.

Large Size Fertilizer Distributor. It will hold a $16 \bar{\imath}$-pound sack of fertilizer-you don't hare to stop and fill so often, and in most cases you can finish your long rows and not hare to fill up in middle of the row.

\section{Hoover Planter With Fertilizer Drill}

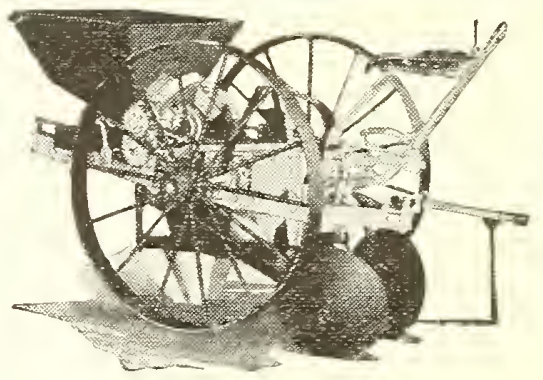

This is a one-man planter of exceptional merit. It will plant $\mathbf{1 0 0}$ per cent correct a $\mathrm{n} d$ sare the extra man. It has been and is being used in Maine by the largest growers.

Price, $\$ 100.00$.

\section{Hoover Elevator Potato Digger}

Few farm implements sare as much time and labor as a satisfactory Potato Digger. In the HoOVER we hare the best and lightest draft.

With Separator, $\$ 110.00$.

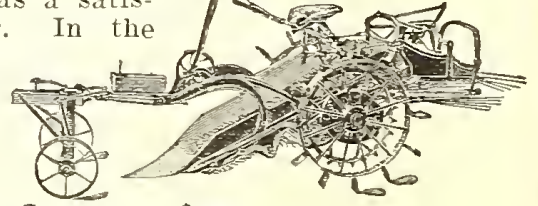
Without Separator, $\$ 100.00$.

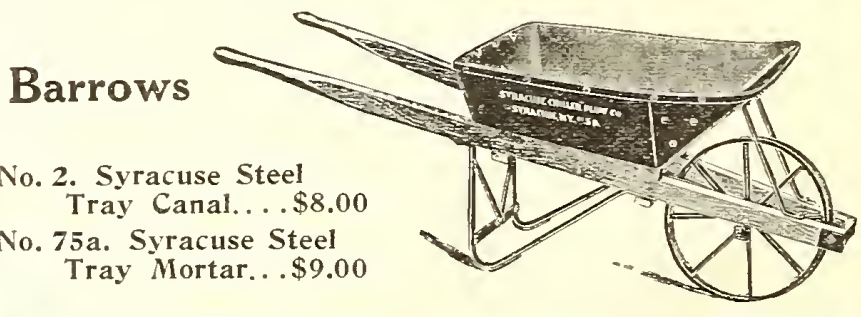




\section{LAWN MOWERS}

\section{Coldwell's Regal Mower}

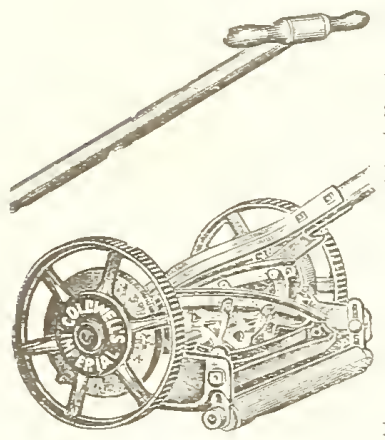

There has been a demand for a five-kuife Lawn Mower, one that will leare the 1 a $\pi$ n perfectly smooth and eren. In this machine Te hare one.

14 -inch. .\$20.00 16-inch. .\$21.50 18 -inch. .\$22.50

\section{Coldwell's Suburban} Lawn Mower

BALL BEARING

This latn motrer is made to meet the demand for a first-class ball-bearing machine which can be purchased at a price within the reach of all. It is made throughout of best srade material, and the workmanship is unsurpassed. The driping wheels are $s$ inches in diameter and the revolring cutter has four blades. Which insmes fineness and erenness of cut. 12 -inch...\$9.75 1t-inch...\$10.00 16-inch...\$10.75

\section{Coldwell's Improved Horse Mowers}

Fitted up thronghout with the best of steel shafting, composition bushings or bearings. and polished oak foot boards: Loring Coe's knires, etc., and the workmanship is acknowledged bi the trade in general to be the best lawn mower made in America.

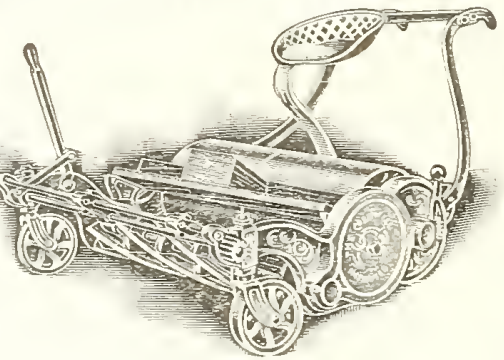

$30=$ Inch. Complete, seat and shafts $(t$ hlades $) \ldots \$ 125.00$ 35=Inch. Complete, seat and shafts (t hlades)... 140.00 $40=$ Inch. Complete, Seat and Shafts $( \pm$ blades $) \ldots .155 .00$ HORSE BOOTS. Per set of four.....\$20.00 and \$25.00

\section{Land Roller}

This is the most popular Land Roller on the market. This implement was th o r oughly tested, a n d its construction was so perfect that it was a success f rom the start.

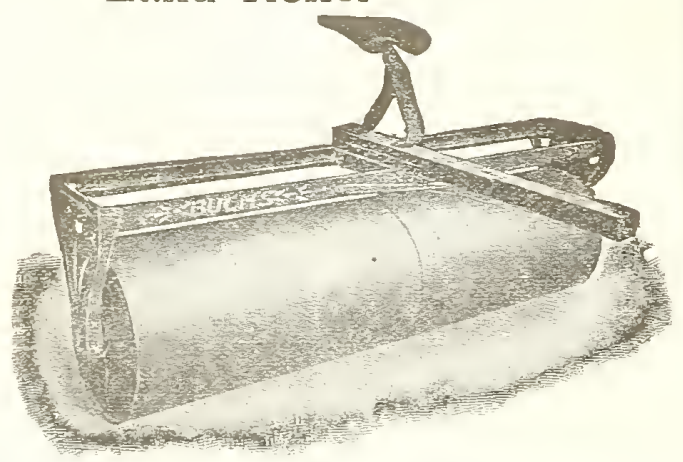

Frames and Hangers. Heary, stiff angles ire used on the sides and ends. to which the steel hangers are securely bolted. and the frame is so arranged that it will carry sufficient weight to suit the requirements. Price, $\$ \mathbf{4 5 . 0 0}$.

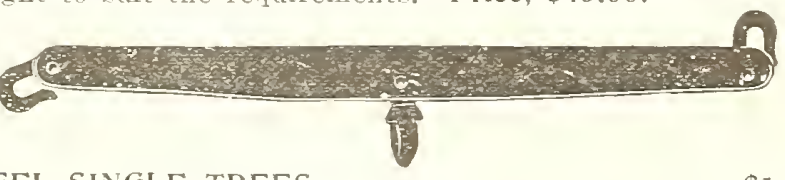

STEEL SINGLE TREES.

$\$ 1.25$

STEEL WAGON DOUBLE TREES........... 2.00

Wooden PIow Set, Complete................. 4.00

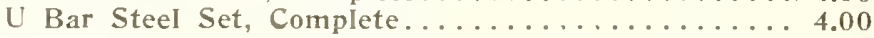

\section{Coldwell's Imperial}

\section{EASIEST RUNNING LAWN MOWER MADE}

THE IMPERIAL is one of our best Mowers, the principal feature being that the knife is securely bolted to the sides, thus insuring a perfectly rigid frame. The knives are adjusted bs means of our patent hanger, and a locking screw holds them securely in place. This hanger is so constructed that all wear can be taken up in the bearings. The triple pawl ratchet is the simplest and most durable on the market. Prices-High WheeI, 4=BIade.

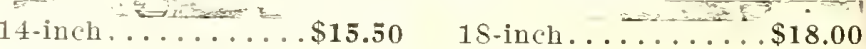
16 -inch........ 16.75 20-inch....... 19.00

\section{The Cadet Lawn Mower}

This is a good Lawn MIower to sell at a medium low price, and give the purchaser full value for his moner. The gears
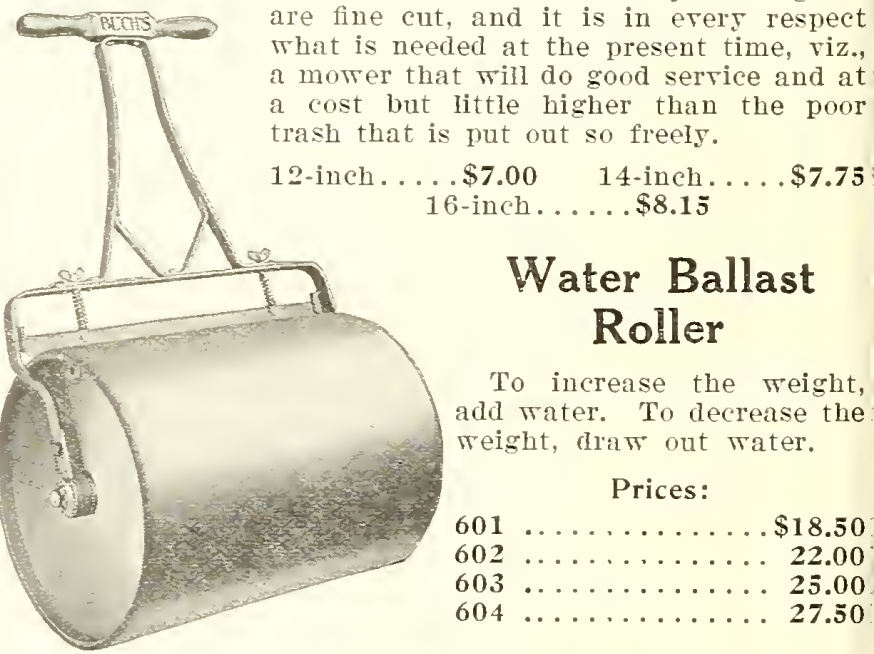

To increase the weight, add water. To decrease the weight, draw out water.

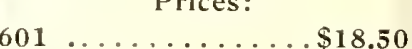

$602 \ldots \ldots \ldots \ldots 22.00$

$603 \ldots \ldots \ldots \ldots 25.00$

$604 \ldots \ldots \ldots \ldots 27.50$

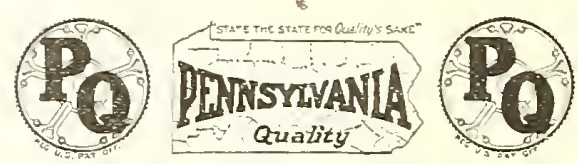

\section{Lawn Mowers}

STANDARD-High WheeI:

15 Inch . . . . . . . . . . . \$25.50

17 Inch . . . . . . . . . . . . . . 28.50

19 Inch .................... 32.50

21 Inch . . . . . . . . . . . . 36.50

STANDARD-Low WheeI:

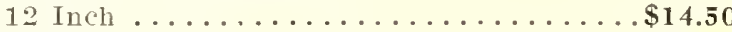

$1+$ Inch . . . . . . . . . . . . 17.50

16 Inch . . . . . . . . . . . . . 20.00

18 Inch . . . . . . . . . . . . . 23.00

PENNSYLVANIA GOLF MOWER-High WheeI:

17 Inch . . . . . . . . . . . . \$34.00

19 Inch . . . . . . . . . . . . . 38.00

21 Inch ................... 42.00 


\section{Horse Collars}

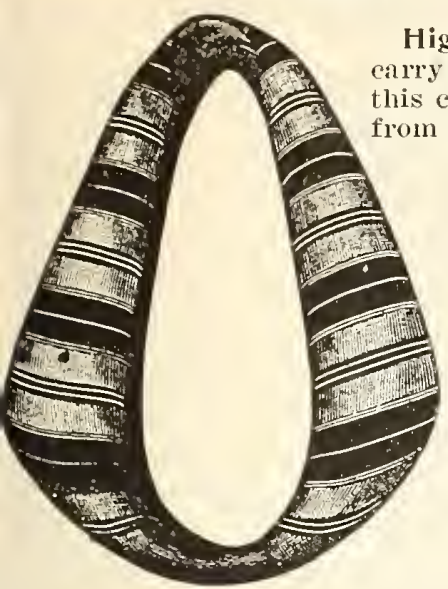

High=Grade Scotch Collars. IVe arry the largest line of Collars in this city, and can furnisli any size rom 16 to 24 inches.

\section{Thick Lined Collars $\$ 3.00$ to $\$ 5.50$ \\ Sweeney Collars \\ $\$ 3.50$ to $\$ 6.25$}

Red Edge Collar Pads 50 cts.

All Brown Collar Pads 75 cts.

Ask for price by the dozen.

\section{Stewart No. 1 Enclosed Type Clipping Machine}

The Only Ball=Bearing Clipping Machine

It is without exception the most perfect clipping machine ever made. It runs practically without friction or wear. The price puts it within reach of every farmer and horse owner. The gearing is all enclosed in a dust-and dirt-proof case, and runs in oil constantly.

Price, complete for horses, $\$ 12.00$.

\section{Plow Harness}

Plow Harness, complete, per set (less Collar) .........\$7.50

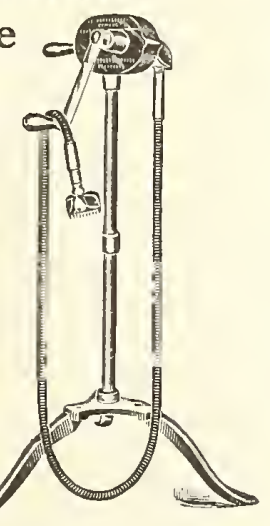

Trace Chains, per set............\$1.15 to $\$ 1.25$ Breast Chains, per set.............75 to 1.60

Butt Chains, per set.............. to 1.35

\section{Fly Nets}

Yellow cord, extra heavy, 5 bars and 50 lashes. Price, $\$ 1.50$.

WE CARRY

A FULL LINE OF

\section{Cart Harness}

Extra Heavy Cart Breeching.............\$10.50

Extra Heavy Cart Saddle................ 8.00

Cart Bridles, extra heavy ................ 3.25

One=Inch Cart Reins, riveted............. 2.60

Heavy Cart Hames, per pair............... 1.75

\section{Halters}

Leather, $11 / 1$ in., Russet..........\$1.75

Leather, $11 / 1$ in., machine made. $\$ 1.80$ to 2.00

Web Cotton .................. . . . . . .

Leather Cow Halter.........\$1.25 to 2.00

Leather Ties ............... 1.00

\section{Back Bands}

Folded Duck, Elbel's patent hook, 46 to $4 \mathrm{~S}$ inches long, 5 inches wide.

Price, 85 cts.

Single Web Back band, Plow Boy, 45 cts.

A FULL LINE OF WHIPS AND A GENERAL LINE OF HARNESS ACCESSORIES ALWAYS ON HAND

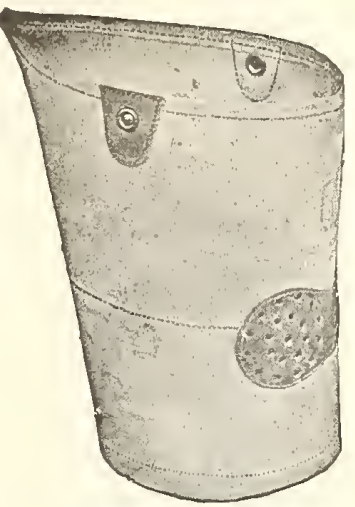

\section{Feed Bags}

Star Wood Bottom. A good, reliable bag for the money. Price, 50 cts.

No. $10 \mathrm{Bag}$, made of 12-oz. duck, metal eyelets; very durable. Price, $\$ 1.25$.

No. 8 Special. This bag is especially well made of $12-0 z$. duck has reinforced sides; leather ventilators and sole leather bottom.

Price, \$1.15.

Special prices in dozen lots.

HORSE WEIGH'TS, from 15 to 30 lbs., 6 cts. per lb.

WEIGHT STRAPS, \$1.25.

WEIGHT CHAINS, $45 \mathrm{cts}$.

MILLER'S HARNESS DRESSING. Pt. 55 cts.; qt. 80c. MILLER'S I. X. L. HARNESS OIL. Pt. 40 cts.; qt. 60 cts.; $\quad \mathrm{t} / 2$ gall. $\$ 1.10$; gallon, $\$ 1.80$.

MILLER'S HARNESS SOAP. $1 \mathrm{lb} .40 \mathrm{c}$; 5=Ib. can, $\$ 1.35$.

NEATSFOOT OIL. Gallon, \$1.35.

HAME STRAPS. I inch, machine made. $35 \mathrm{cts}$. each; $\$ 3.50$ per dozen.

HAME STRAPS. Hand made, 1 inch. 40 cts. each; $\$ 3.75$ per dozen.

\section{Hames}

No. 280 Concord Hames, very heavily ironed, with hook or elip; brass ball top. Price, per pair, $\$ 2.50$.

No. 61 Virginia Cart Hames, rock elm or ash wood, $1 / 8$-ineh stiff-bottom loops, $3 / 4 \times 1 / 4$ inch steel backs. Three mortise top loops. Heavy wrought steel hooks. Varnished. Polished irons. Sizes, 19 to 22 inches, $\$ 2.65$ per pair; 22 to $24, \$ 2.00$ per pair.

No. 15 Brass Ball=Top Hame.

$\$ 2.50$

\section{Blankets}

We recommend $\mathbf{5 A}$ Horse Blankets because of their strength, warmth, horse protection, and their long wear. They are leaders. Prices from $\$ 1.25$ to $\$ 6.00$.

STORM COVERS FOR HORSES.

.$\$ 5.75$

STORM APRONS FOR WAGONS ..........

STABLE BLANKETS ............... 3.00

CURRY COMBS ................... 25

HORSE BRUSHES ............ .50 to 2.75

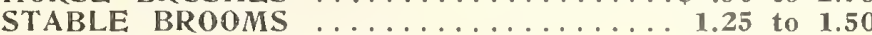

MANURE STABLE FORKS .......... 1.00 to 2.00 


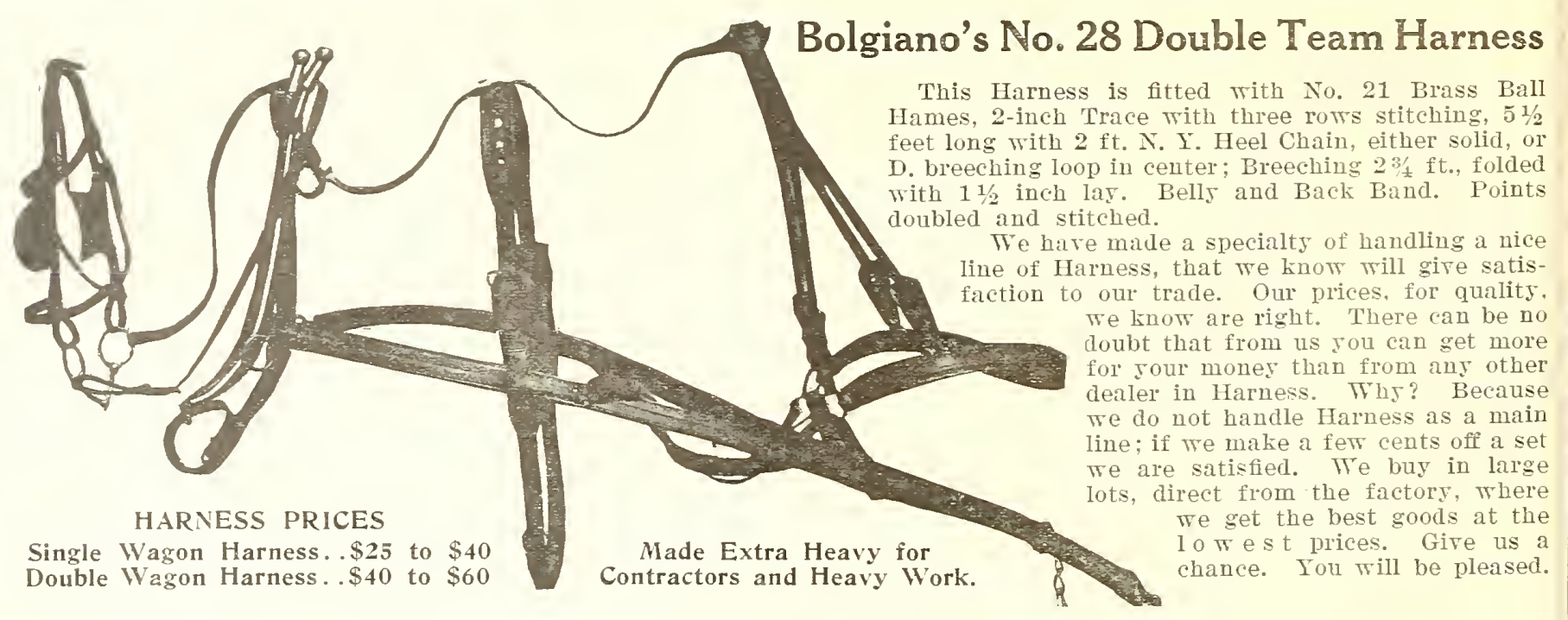

\section{Hand and Power Corn Shellers}

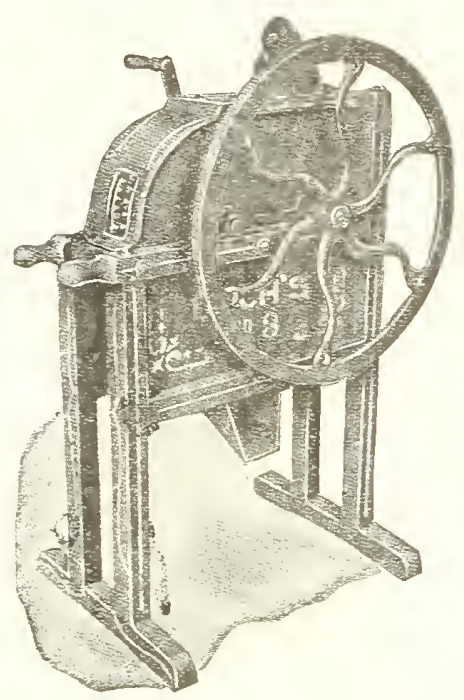

No. 3 Single Hole Sheller $\$ 14.50$

No. 4 Single Hole Sheller $\$ 14.50$

No. 7 Double Hole Sheller For lland or Power $\$ 30.00$

\section{Cider Mills}

SENIOR. This is our largest-sized Mill, adapted for hand or power, with a detachable handle on either side. The top set of rolls first mash the fruit fine, and the bottom set grinds it up thoroughly, breaking all the cells., so that the cider is entirely extracted.

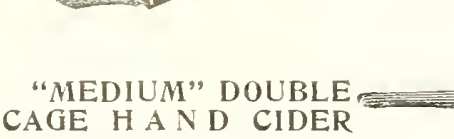
CAGE H A N D CIDER

MILL. Similar to the Senior described above.

"JUNIOR" DOUBLE C A GE HAND CIDER MILL. Built on the same principles as Senior and Medium. Has one handle. This is the smallest Double Cage Mill we handle, A first-class mill for family use.

Write for prices.

These machines are built by leading manufacturers, and are guaranteed to give satisfaction.

\section{Pumps}

W 00 D P U M S. We sell the Buckeye, which is conceded to be the best on the market. Made of cucumber wood, and not poplar. as many ot the so-called cucumber-wood pumps are made. All Pumps porcelain lined.

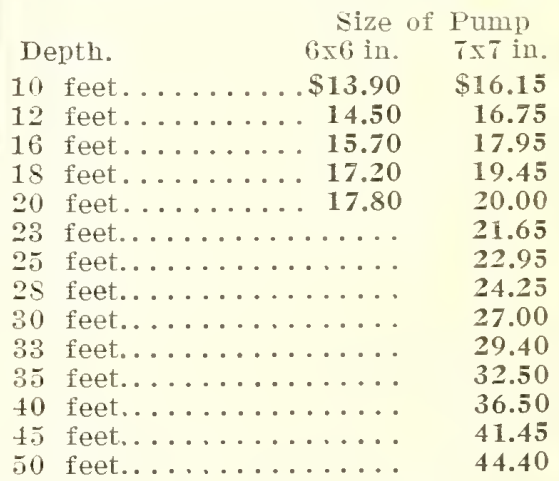

\section{Tubing and Miscellaneous Pump Parts}

$4 \times 4$ Inches, 12 feet long and under. per foot, $30 \mathrm{cts}$.

4x4 Inches, 12 feet long or orer, per foot, $32 \mathrm{cts}$.

$6 \times 6$ Inches, extension tubing, per foot, $80 \mathrm{cts}$.

$6 \times 6$ Inches, coupling and bands for $4 \times 4$-inch tubing, $90 \mathrm{cts}$.

Buckets, 4-inch, each \$1.50.

Buckets, $31 / 2$-inch, each $\$ 1.25$.

Handles, any size, $40 \mathrm{cts}$.

Handle Links, each 50 cts.

Check Valves, each $25 \mathrm{cts}$.

Iron Spouts, each 60 cts.

Splice Straps, per pair 50 cts.

Sucker Rod, per foot $8 \mathrm{cts}$.

Handle Brackets, per set $50 \mathrm{cts}$.

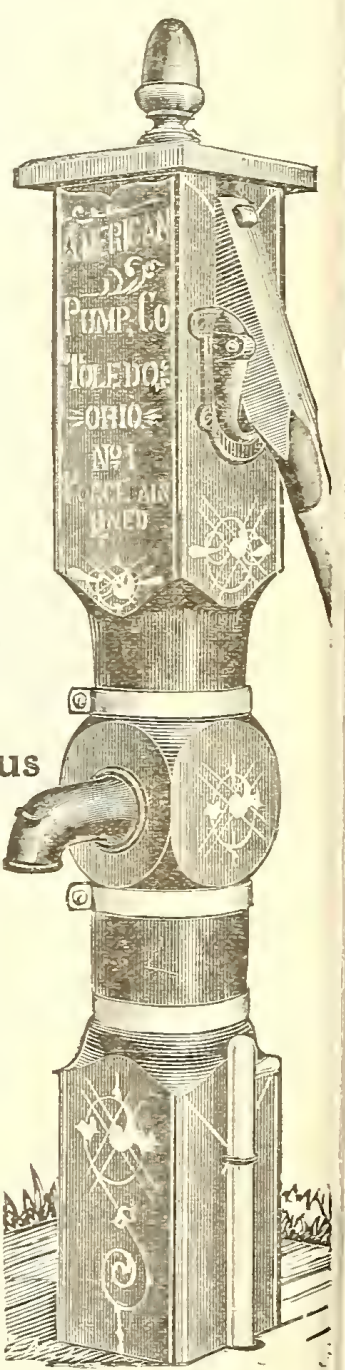




\section{Boiler and Feed Cooker}

II e a $\nabla \boldsymbol{y}$ coldrolled steel furnace; extra large feed loor, with wrought - i $1^{\circ} \mathrm{n}$ handles, firmly riveted on Iiettles, s m o o t h, heavy cast iron. Door, frame and flue collar cas t iron. It does n o t buckle or warp from the heat; designed to set on ground or brick foundation ; is espe. cially adapted to cooking feed

rendering lard, making soap, scalding hogs, poultry, etc. Cast-iron flues are constructed inside this, retaining heat and economizing fuel.

30 gal. capacity ...\$16.00 40 gal. capacity...\$18.50 33 gal. capacity ... $17.00 \quad 48$ gal. capacity... 19.00 53 gal. capacity....21.00

\section{"Ohio" Hand Feed Cutter}

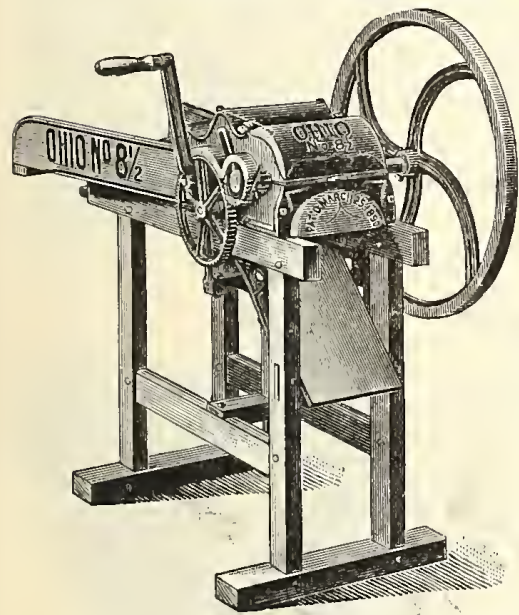

Capacities: One man can easily cut a bushel of hay with No. $8 \frac{1}{2}$ in 40 seconds, and with No. $10 \frac{1}{2}$ in 30 seconds, and a boy 12 years old can use them successfully.

Sizes and Prices:

No. 81/2 K1 — "Ohio" Hand Feed Cutter, with one $8 \frac{1}{2}-$ inch knife; for hand use only; weight. 165 lbs. Price, $\$ 34.00$.

No. $81 / 2 \quad \mathrm{~K} 2-\mathrm{S}$ a $\mathrm{me}$ machine, equipped with two knives. Price, \$37.

Pulley for Power on above cutters, $\$ \mathbf{2 . 0 0}$.

\section{Nobby Feed Cutter}

Simple, durable, handsome, cheap. It has an 11-inch tempered curved knife, which can be adjusted to take up the wear, thus giving a perfect shear cut at all times. Price, $\$ 6.25$.

\section{“Ohio" Light Draft Suction Blowers}

\section{No. 60. No. 90 .}

$\$ 225.00 \$ 250.00$

Capacity, tons per hour...... 5 to $7 \quad 7$ to 10 H. P. required, gasoline...... 6 to 8 s to 10 Length of knives (two)......11-inch 13-inch Weight, pounds, unmounted.... 835 Weight, pounds, mounted..... 1,210

Speed recommended, 600 to 800 R.P.M.

Four lengths of eut, $7-16,9-16,1$ and $11 / 2$ ins.

Pulley, covered, regular, 10-inch diameter by 6-inch face.

No. 805. T R U C K for mounting machines; weight, 360 pounds. Price, $\$ 67.00$.

\section{Bolster Springs for Bed Wagons}

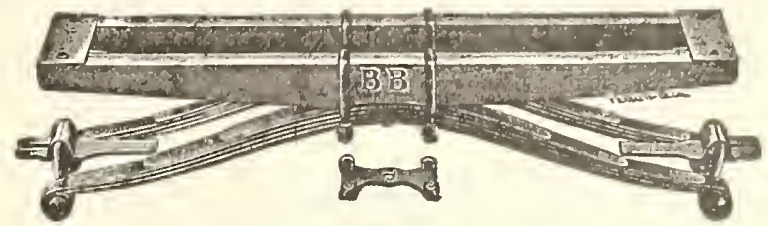

1000 lbs. capacity . .\$7.50

1500 lbs. capacity... 8.25

$2000 \mathrm{ll}$ s. calucity . . 11.00

$3000 \mathrm{lbs}$. capacity

$\$ 13.50$

3500 lbs. capacity

14.00

4000 lbs. capacity

14.50

2500 lbs. capacity ... 12.00

5000 lbs. capacity

17.00

\section{Farm and Contractors' Cart}

With 5 and 6 inch tires; also extra heavy Contractors Carts made specially to order when wanted. These carts are very strong, heavily ironed, nicely painted, striped and varnished.

$\begin{array}{cccc}\text { Size of Axle. } & \text { Size of Tire. } & \text { Diameter of Wheel, } & \text { Price. } \\ 11 / 2 \mathrm{ins} . & 3 \mathrm{ins} . & 4 \mathrm{ft} .10 \mathrm{in} . & \$ 85.00 \\ 2 \text { ins. } & 3 \mathrm{ins} . & 4 \mathrm{ft} .10 \mathrm{in.} & 95.00\end{array}$

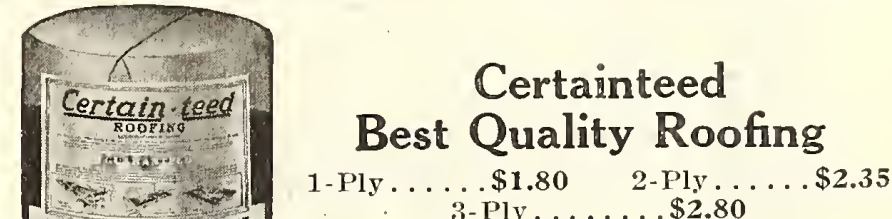

$$
3 \text {-Ply . . . } \$ 2.80
$$

We have in stock the finest prepared roofing offered by anyone. We are willing to guarantee that for length of service it cannot be surpassed by any roofing of its kind. With a couple of coats of prepared paint it will last a lifetime and will give perfect service during the whole period.

\section{TAR PAPER}

Two squares.............\$3.00

RED AND GREEN SLATE TOP ROOFING, Price, $\$ 2.50$. 


\section{Hog and Cattle Steel Wire Fencing}

726-26 in. High Hog Fence, 7 bars.......46 cts. per rod 832 -32 in. High Hog Fence, 8 bars.......56 cts. per rod $845-45$ in. High Cattle Fence, 8 bars......46 cts. per rod 1047-Extra Heary ..............70 cts. per rod Special prices on quantity.

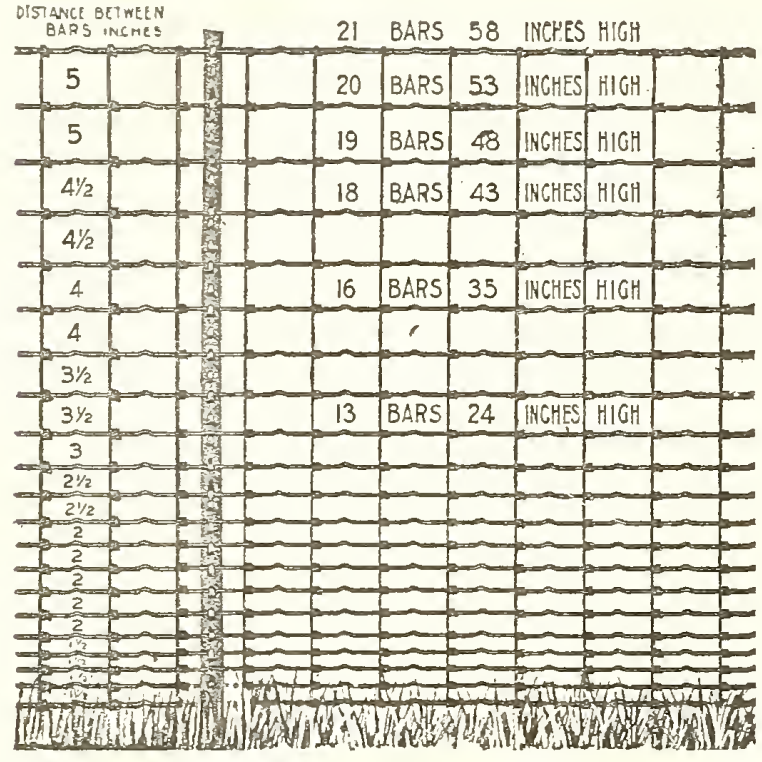

\section{American Steel Poultry Fence}

1948-48 inches high............58 cts. per rod 2053 -53 inches high..............63 cts. per rod 2158-58 inches wide............65 cts. per rod

\section{Diamond Mesh Poultry Fence}

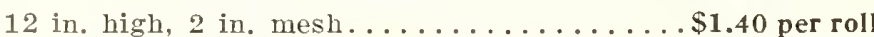
18 in. high, 2 in. mesh............. 2.00 per roll 24 in. high, 2 in. mesh............. 2.55 per roll 36 in. high, 2 in. mesh............. 3.50 per roll 48 in. high, 2 in. mesh.............. 4.55 per roll 60 in. high, 2 in. mesh.............. 5.60 per roll 72 in. high, 2 in. mesh............. 7.35 per roll

Hog and Cattle Barb Wire at Lowest Market Prices.

\section{Specification $\mathrm{L}$}

No. 10 Top and Bottom, No. $12 \mathrm{x} / 2$ Stay

726-26 in. High Hog Fence, 7 bars......37 cts. per rod 1047 - 6 in. stays, Cattle and Hog.........55 cts. per rod 1047-12 in. stass, Cattle............40 cts. per rod

\section{Fuller \& Johnson Model "N" Gasoline Engines}

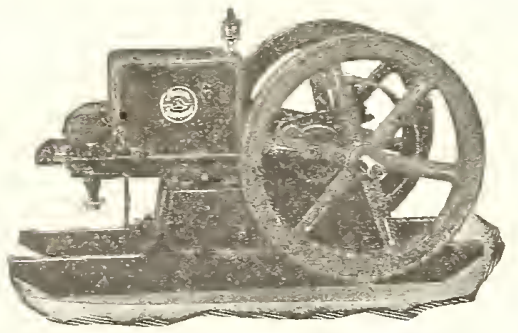

Special Price on Model "K" Kerosene Engine Upon Application.

1. The simplest a $n d$ most perfect System of Hopper Cooling.

2. Frost Proof.

3. Large straight-sided Hopper. Cylinder completely immersed in water as in our Double Efficiency line. No narrow water jacket spaces to clog up or freeze or break.

Horsepower and Prices:
H. P.......\$ 70.00
5 H. P.......\$175.00
H. P........ 120.00
7 H. P........ $\mathbf{2 5 5 . 0 0}$

\section{Fancy Lawn Fence}

The fabric illustrated herewith is superior to any Lawn Fence on the market. The upright wires are corrugated their entire length instead of at intervals. Close enough at bottom to turn the smallest chicks.

The uprights are of No. 9 heary galfanized wire, spaced $2 \%$ inches apart, with an extra upright of No. 9 interwoven at the bottom, giving a spacing of $1 \frac{3}{8}$ inches. The cables are of hearily galranized wire spaced 6 inches apart, except the two top cables, which are spaced $1 / 2$ inch apart.

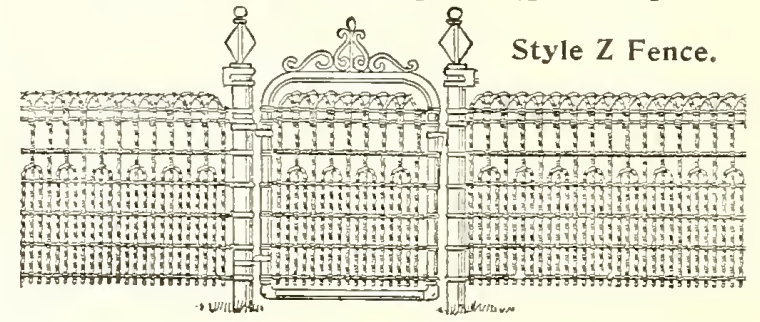

Style $\mathrm{X}$.

Style Z.

16 in. high.......... 8 cts. per ft.

22 in. high..........10 cts. per ft.

36 in. high........... $12 \mathrm{cts}$. per ft. $16 \mathrm{~d} / 2 \mathrm{cts}$. per ft. 42 in. high........... $14 \mathrm{cts}$. per ft. $18 \mathrm{l} / 2 \mathrm{cts}$. per ft.

\section{LAWN GATES}

Plain. FancJ.

$3 \mathrm{ft}$. by 36 in..............\$3.00 \$4.00

$3 \mathrm{ft}$. by 42 in................ 3.25

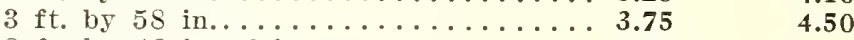

$12 \mathrm{ft}$ by 42 in., drice gate........ 8.50

$12 \mathrm{ft}$. by 50 in., drive gate........ 9.00

$12 \mathrm{ft}$. by 58 in., drive gate......... 9.50

\section{De Laval Cream Separators}

OFer 1,600,000 De Laval Separators now in use. See and try a De Iaval before busing a Separator.

Any Separator that wastes c rea $\mathrm{m}$ is expensire. A De Laral will not.

\section{Capacity and Price:}

Pounds

No. per hour.

$5 \quad 225$

10350

12500

$15 \quad 750$

$17 \quad 1000$

$19 \quad 750$

201000

221350

$25 \quad 1350$

Turbine
Turbine
Turbine

Price.

$\$ 65$

80

90
110

$12:$

16

200

260

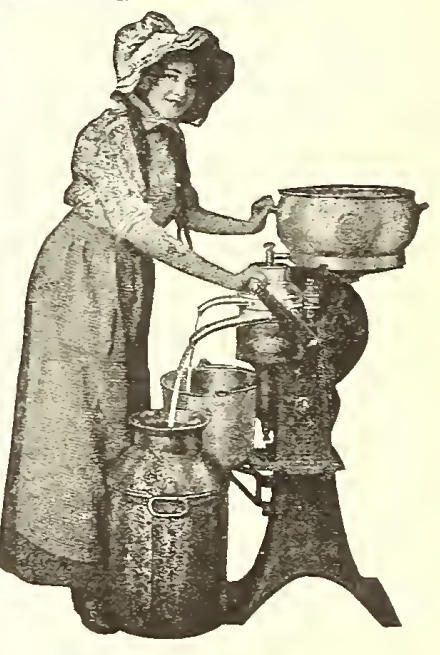

\section{Push Carts}

No. 0 Lansing.......\$21.00

No. 1 Lansing........ 18.00

No. 2 Lansing........ 16.50

No. 132 Merrimac..... 10.00

No. 232 Merrimac..... 10.75

No. 12 Monitor........ 13.00

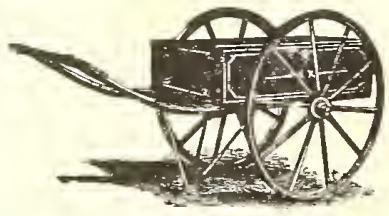

AUTOMOBILE OIL..........70 cts, per gallon GAS ENGINE OIL.........70 cts, per gallon 


\section{Fuller \& Johnson Pumping Engine}

No Well Too Deep For This Farm Pump Engine. Cannot Freeze or Overheat.

No Hours Too Long For It to Work.

At last we have found a pump engine that serves all the needs of the farmer and does it in the best possible manner. We investigated a score or more different makes and designs of portable engines to find the one best suited for our customers. TVe selected Fuller \& Johnson Farm Pump Engines. It is the most wonderful portable engine made.

400 to 1500 Gallons per Hour.

Think of it! All the fresh water you want at any time or any place. Works in any well, regardless of depth. This farm pump engine completely solves the perplexing problem of Water Supply for the farm in winter as well as summer. Pumps all the water needed for the house, dairy, barn, feed lot and pasture in a few hours. Costs less to operate than a tank heater and eliminates all bother and trouble.

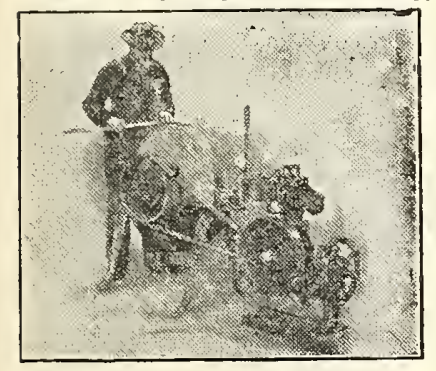

Driving a Grindstone.

\section{Handiest Little Worker On the Farm.}

Ensuring a reliable water supply for the farm is but one of the ways the Farm Pump Engine proves its superiority. It has pulley for running any kind of hand or foot power machinery. It helps the womell folks in the dairy and the laundry. Runs the grindstone, feed mill, fanning mill, etc., for the men. Does the work of two extra hired men.

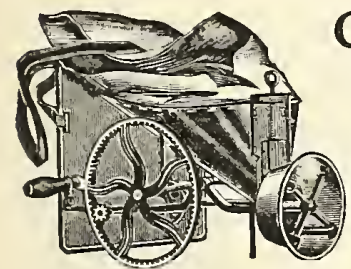

\section{Cahoon Seed Sower}

For sowing Clover, Timothy, Millet, Oats, Wheat, Rye, Buckwheat, etc. Standard seeder of the world. A model for accuracy and durability. Malleable iron frame. Steel hopper and gate. Brass discharger. Price, \$5.50.

\section{Manila, Sisal and Cotton Rope}

Always on hand, the best Manila, Sisal and Cotton Rope, in coils or by the piece, at prices consistent with the

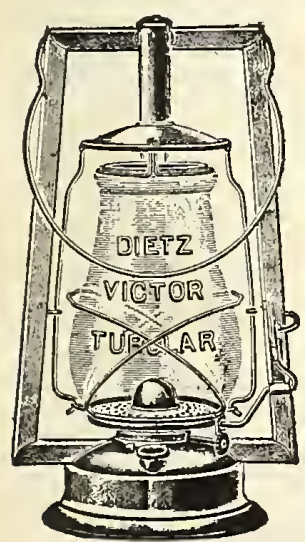
quality. Prices on application.

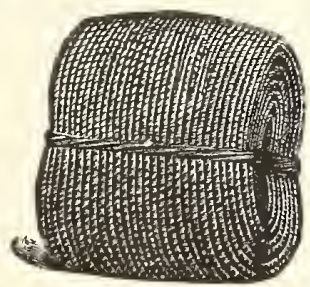

\section{Dietz Lanterns}

Dietz Victor Lantern.......\$.90

Dietz Victor Red Lantern..... 1.25

Dietz Dash Lantern ........ 1.40

Dietz Regulation Lantern for Wagons.............. 1.60

Dietz Storm King Lantern (can't blow out) ............. 1.50

Dietz Little Wizard (can't blow out)................

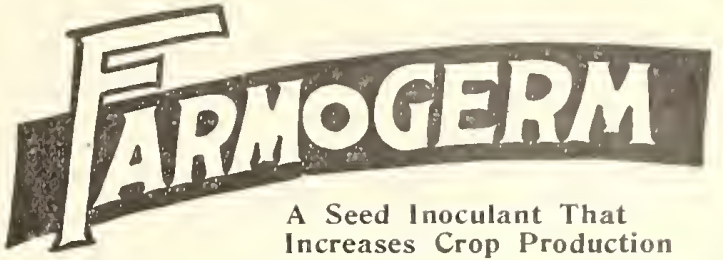

Seeds of all legumes-beans, peas, clover, alfalfa, and re lated crops-will yield far better if inoculated with FARMO GERM, and in addition leave in the soil a heavy deposit of nitrogen which benefits all succeeding crops. Gardeners and farmers who have used Farmogerm would not be without it.

\section{Farmogerm Stays Good Indefinitely.}

FARMOGERM keeps for years. Because of the method of sealing the bottle - a patented stopper which admits filtered air and keeps out all impurities. Just add water and shake the bottle and sprinkle over the seeds as directed. Your crop will benefit beyond your expectation.

\section{Farmogerm Is Economical.}

The one-acre size bottle of FARMOGERM is sufficient for 15 pounds of clover, 20 pounds of alfalfa, 100 pounds of Canada Field Peas, 60 pounds of Vetch, etc. A different bacteria is required for each crop. When ordering, be sure to state what crops you wish to inoculate.

\section{Farmogerm Prices Reduced.}

New scientific methods of manufacture have given lower prices. Yon cannot now afford to do without FARMOGERM.

A special composite culture is prepared for peas, beans and sweet peas-1/4-acre size only. You'll get more peas and beans, and larger sweet peas by using this. Ask for No. 5-Price, 50 cts.

FARMOGERM prices are: $1=$ acre size, $\$ 1.00 ; \quad 3=$ acre size, $\$ 2.50 ; \quad 12=$ acre size, $\$ 9.00$. Full directions accompany each bottle.

\section{Norcross Weeder}

This Tool, introduced about four years ago, has more than made good in every respect. It can so easily be changed from a 5 -tooth to a 3 -tooth weeder or cultivator for hand use.

Price, 95 cts. and \$1.25.

MIDGETT NORCROSS Price, 50 cts.

\section{Binder Twine}

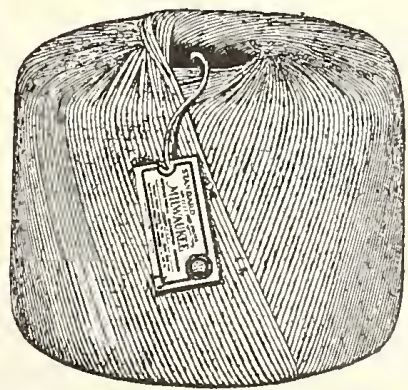

It is well understood that good binder trine is essential to successful binding. The harvest season lasts only a few days and delays nearly always result in more or less loss. Binder twine that kinks and breaks is not worth hauling home, because it is not only a source of annoyance while harvesting the grain, but it also delays the work of shocking. Uniform size and strength are the characteristic features of our binder twine. It will not kink and clog the knotter or pull thin and break. The different brands of twine are Sisal, Standard, Manila and Pure Manila. Price, $15 \mathrm{cts}$. per lb. 

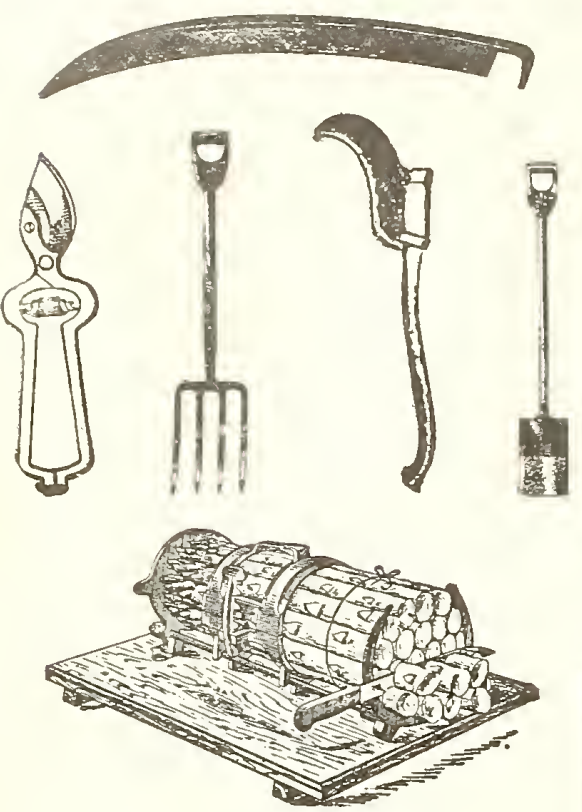

ASPARAGUS BUNCHER

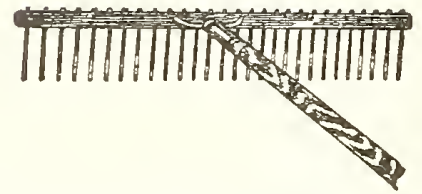

IRON AND STEEL GARDEN RAKES 12-tooth, Malleable Iron Ben t

Tooth.............. \$.45 12-tooth, Steel Rake........ $\mathbf{. 8 5}$ 14-tooth, Steel Rake ........ .95 14-tooth, steel Bow .......... 1.20 16-tooth, Steel Bow .......... 1.25

\section{SNEATHS}

Patent....\$1.45

Rings.....\$1.50 Beatty Price, $\$ 3.00$.
SCYTHE STONES

Darby Creek ............\$ .20

English Round ............... .25

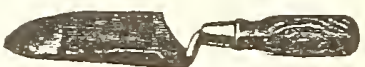

GARDENER'S

TRANSPLANTING TROWELS

Strong. Ladies'............\$.20

Forged Steel .............. . .50

Heary Forged ...............75

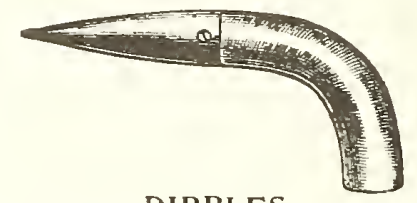

DIBBLES

Bent Wood Handles, Steel Points.\$ .50 Sarred Tood Handles, Steel Points .40 All Iron Handles, Steel Points.... .60

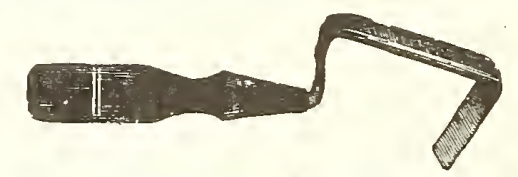

HAZELTINE WVEEDER

Price, 50 cts.

SPADES

Marvel, "D" Handle.........\$1.75

Ames, " $D$ " Handle.......... 2.10

SPADES, LONG HANDLE

Ames .............\$2.10

\section{SPADING FORKS}

Wood. "D" Handle..........\$1.60 Malleable, "D" Handle......... 1.50

All Guaranteed.
Malleable Shank ............ 25

\section{BRUSH AXES}

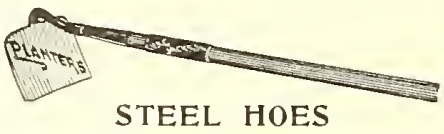

Sizes $6,61 / 2,7,71 / 2,8$.

Solid Shank ............\$.75

Solid Socket .............. $\quad .80$

Malleable Iron Socket, steel blade. $\quad .80$

Planters' Hoe, heavy handle, suit-

able for stiff ground........ .90

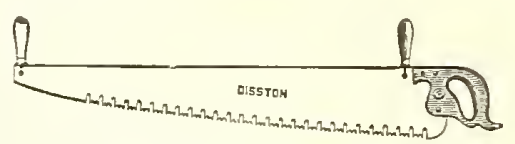

\section{CROSS=CUT SAIVS}

$31 / 2$ ft. 1-Man X-Cut Saw ......\$3.75

4 ft. 1-Man X-Cut Saw...... 4.25

$41 / 2$ ft. 2-Man X-Cut Saw..... 3.00

5 ft. 2-Man X-Cut Saw...... 3.25

$51 / 2$ ft. 2-Man X-Cut Saw...... 3.50

ft. 2-Man X-Cut Saw..... 4.00

\section{SCYTHES}

Waldron, 36 and 38 in.. \$2.75 to $\$ \mathbf{2 . 8 5}$

Kelly's Grass ............. 2.00

Kelly's Bush, Assorted....... 2.00

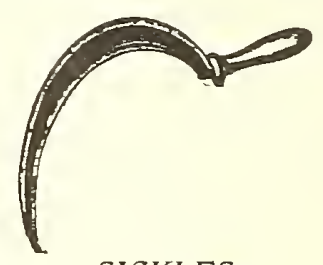

SICKLES

Solid Back No. 3..........\$ .60

\section{PRUNING SHEARS}

Trood Handle, Steel Plate......\$1.75

Ialleable Handle, Steel Plate.... $\mathbf{1 . 0 0}$

8 ft. Water's Tree Pruners...... $\mathbf{2 . 0 0}$

10 ft. Water's Tree Pruners...... $\mathbf{2 . 2 5}$

12 ft. Water's Tree Pruners....... 2.50 Grass Shears ............ .50

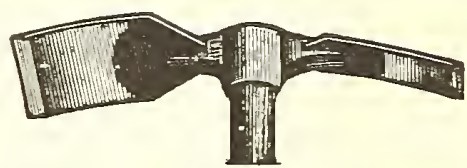

MATTOCKS, HEAVY STEEL

Steel 4 in. Long Cutter........\$1.00 Steel 3 in. Contractors......... 1.25 Handles. extra ............ .50

Garden Mattock ............ .75

Potato Drags. Light.......... 1.00

Potato Drags, Heavg......... 1.35 them by the hundred to pleased customers. Weight, a b o u $\mathrm{t} 20$ pounds.

Price, No. 1 :

Weight, about 20 lbs.

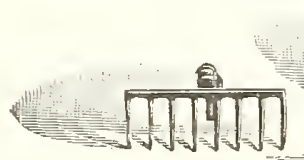
sprin : it has a cultivator and a hoe; also, a pulverizing rake. It is complete in evers decomplete in evers de-

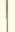

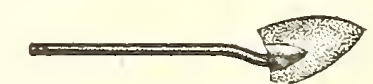

SHOVELS, LONG HANDLES

Jackson, Round Point.........\$1.65 Ames, Round Point.....\$2.00 to 2.10 Ames, Square Point..... 2.00 to 2.10

Have you ordered all the seed required? Perhaps if you take another look through the Catalog you may find some= thing you have overlooked. Time is money as applied to all garden and farm operations. 


\section{Fertilizers for the Farm, Lawn and Garden}

During the entire history of the world there never was a time that food production was as essential as it is today. 'The world is on the rerge of starvation. It is said that more than 1,000,000 people will die of starvation during the next twelre months-because there is not food enough to supply them. Now, increased production is necessary, and increased production can be accomplished only by planting and fertilizing. You must do you best, GOOD FER'ILI\%ERS AIE ABSOLUTELI ESSENTIAL.

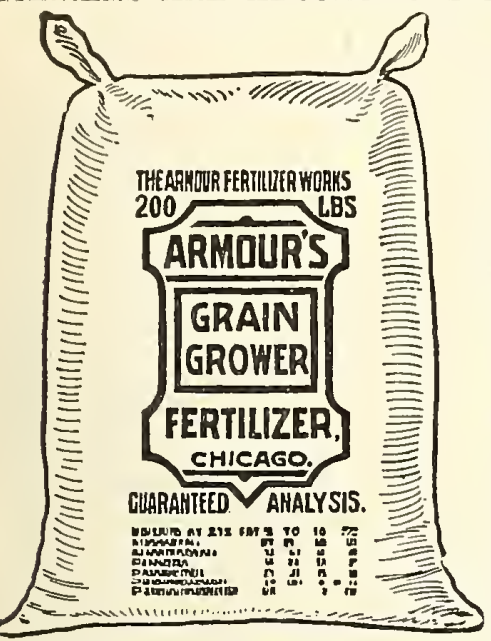

TEN PER C E N T TRUCKER has given our trade the greatest satisfaction. It is principally used for very early crops, and has more than paid for itself in the advancer prices received for early vegetables. As a tobacco bed fertilizer it is excellent. Analysis: 10 per cent Ammonia, 5 per cent Phosphoric Acid, 2 per cent Potash.

SE VEN PER CENT TRUCKER is all right, because every user says so, and one of the best evidences aside from this is that our sales show inrecommend this Fertilizer to all who look forward to early and good crops. Analysis 7 per cent Ammonia, 6 per cent Phosphoric Acid, 2 per cent Potash.

AMMONIATED BONE. This is used largely by the best Truckers for general crops. Analysis: 2 per cent Ammonia, 9 per cent Phosphoric Acid, 2 per cent Potash.

\section{Fertilizing}

A great many first-class Gardeners and Farmers have come to see the advantage of the use of chemicals on their grounds and in building up their soils. We have for a number of years made this a special feature of our business, and are prepared to furnish any of the leading sorts in any quantity.
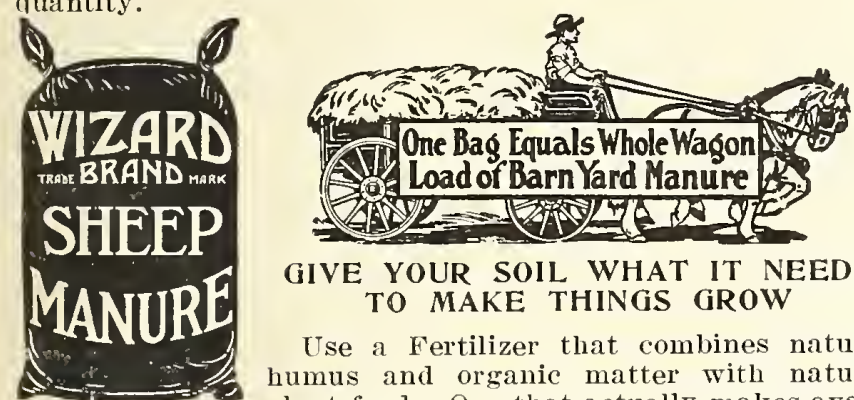

GIVE YOUR SOIL WHAT IT NEEDS TO MAKE THINGS GROW

Use a Fertilizer that combines natural humus and organic matter with natural plant food. One that actually makes available and useful a great amount of fertility lying dormant and inactive in the soil.

W I Z A R D BRAND PULVERIZED SHEEP MANURE AND SHREDDED CATTLE MANURE is a particularly efficient material for making up the compost supply. It is used in this way by many florists who have limited space and who cannot mix their compost in the old way. It acts quickly, has a better effect on the soil, and is much more easily handled. WIZARD BRAND is jnst this kind of a fertilizer. It's all natural plant food and humus that makes better soil and better crops. No matter what you growfruit, vegetables and grains, or just flowers and grass about the home-WIZARD BRAND SHEEP MANURE "Makes Nature Hustle," and builds up your soil at the same time. Price: 15 lbs. 50 c; 30 lbs. $\$ 1 ; 100$ lbs. $\$ 2.35 ; 1$ ton, $\$ 40$.
GENERAL $2=8=2$. A Fertilizel for reneral uses-that's what its name implies. The demand has been large for just such a Fertilizer. We recommend this grade for most crops. Analysis: 2 per cent Ammonia, 8 per cent Phosphoric Acid. 2 per cent Potash.

PURE RAW BONE MEAL. At the outset we say the bone you should buy and use is Armour's, because it is pure, finely ground and of first quality. There is no bone on the market today that will compare with it; and if you will give it a trial on your land, we confidently believe you will agree in what we say. Analysis: 4 to 5 per cent Ammonia. 24 per cent I'hosphoric Acid, 48 per cent Bone Phosphate.

FISH AND BONE. Last year we sold great quantities of these goods. They gave much satisfaction to our trade. Analysis: 2 per cent Ammonia, 10 per cent 1'nos. Acid.

FINE GROUND DRIED FISH. This Fertilizing material is largely used in mixing Fertilizers. It contains a large percentage of Ammonia, and is quick in action.

FINE GROUND DRIED TANKAGE. Is nsed largely as a base in all Animal Fertilizers, and gives quick and fine results. Contains large percentage of Ammonia and Phosphoric Acid.

\section{Prices on application.}

BLOOD MEAL-FOR ROSES. It is well to remember that all plants require the proper amount of food if they are to do their best. We can recommend Blood Meal to be the rery best for roses.

A tablespoonful to be sprinkled around the Rose Bush, about one inch away from the bush, every two weeks. It is also very valuable as a top dressing in the vegetable garden, flower garden, around house plants, trees and in hot houses. 1 lb. 15 cts.; 3 lbs. 40 cts.; 5 Ibs. 60 cts.

\section{Chemicals}

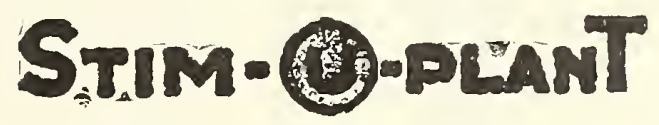

An A11 = the $=$ Vear Fertilizer for Garden and House Plants Growers of fine flowers, shrubs and vegetables for the best markets and for exhibition, fertilize and stimulate them frequently, a little at a time. An excellent fertilizer for the purpose is STIM-U-PLANT, an odorless, highly concentrated plant-food, in tablet form, with guaranteed chemical analysis of 11 per cent Nitrogen, 12 per cent Phosphoric Acid, 15 per cent Potash. The proportions are accurate, there is no unnecessary filler, and in this form you are able to apply plant-food exactly when and where aua as needed.

\section{Make Your Garden a Wonder Garden}

These tablets increase production, heighten color and improve quality. Many professional and amatemr growers nse them extensively all the year round-from early spring until late fall outdoors, during the winter for pot plants, hothonse benches, etc. They are equally good for evergreens and other trees as for a small fern, petunia or other potted plant.

STIM=U=PLANT TABLETS can be used in tablet form, or dissolved in water at the rate of one tablet to the quart. Complete directions with every package.

Order Stim-u-plan'T tablets with your seed and plant order. Price: 10 tablets for $15 \mathrm{cts}$; 30 for $25 \mathrm{cts} . ; 1 \mathrm{no}$ for 75 cts.; 1,000 for $\$ 3.50$.

NITRATE OF SODA. For very early vegetables, and giv ing an early start to grass or grain, there is nothing to equal it.

SOUTH CAROLINA ROCK is used for Phosphoric Acid that it contains, and is valuable in mixing with other goods. 


\section{Insect Destroyers and Insecticides}

Prices On All Insecticides Change Without Notice.

Poison Cannot Be Sent by Mail.

PARIS GREEN. I/4 lb. 20 cts.; I $/ 2$ lb. 35 cts.; lb. 60 cts.; 2 lbs. $\$ 1.20$.

TUBER TON1C. Unexcelled for potatoes. Lb. 40 cts.; 5 lbs. $\$ 2.00$.

LIME AND SULPHUR (B. T. S. Dry Powder). This preparation is scientifically prepared and is widely recommended, and known as the best preparation for San Jose Scale, Oyster Shell Scale, etc. Lb. 35 cts.; POISEA MPS A. BLANGHARD. MEL 5 lbs. $\$ 1.20 ; 10$ lbs. $\$ 2.15 ; 25$ lbs. $\$ 4.25 ; 50$ lbs. $\$ 8.00 ;$
100 lbs. $\$ 14.00 ; \quad 300$ lbs. $\$ 35.00$ Get price on larger 100 lbs.

ATOMIC SULPHUR. This is pure sulphur treated by a special process to convert it into a rery finely divided state in the form of paste, so it can be readily diluted with water and applied as a spray to coat fruit and foliage with a thin film of sulphur to prevent germination of fungous spores. It is recommended for the control of scab on peaches, brown rot on peaches, plums and cherries and cedar rust on apples. Directions: 5 to 7 lbs. to 50 gallons of water. $\mathbf{1}=\mathbf{l b}$. pkg. 30 cts.; 5=lb. pkg. \$1.15; 10=lb. pkg. \$2.00; 25=lb. pkg. $\$ 4.00 ; \quad 50=\mathrm{lb}$. pkg. $\$ 7.25 ; \quad 100=\mathrm{lb}$. pkg. $\$ 13.00$.

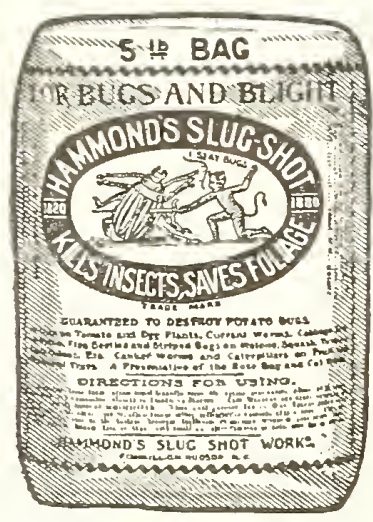

HAMMOND'S S L U G SHOT. Well known remedy for Tobacco Bugs. 5 lbs. 55 cts.

TOBACCO DUST. Fatal to green and black fly and similar garden pests, by simply dusting over the plants. If dug around the roots will keep away all pests below ground and insure health to the plants. 10 cts. per lb.; $\$ 4.00$ per 100 lbs.

ARSENATE OF LEAD (Dry Powdered). Is produced under a new process. Contains at least 33 per cent arsenic. Superior to paste arsenate, stands suspension longer, and has more corering capacity. Lb. 50 cts.; 5 lbs. $\$ 2.00 ; \quad 10$ lbs. $\$ 3.60 ; 25$ lbs. $\$ 8.00 ; 50$ lbs. $\$ 15.50$; 100 lbs. $\$ 30.00$.

BORDEAUX MIXTURE (Dry Powdered). The best fungicide for curing and preventing black rot, mildew, blight, leaf curl. scab or other fungoid diseases on fruits and plants. Lb. 50 cts.; 5 lbs. $\$ 1.85 ; 10$ lbs. $\$ 3.40 ; 25$ lbs. $\$ 7.65$; 50 lbs. $\$ 14.50 ; 100$ lbs. $\$ 27.00$.

BORDEAUX-ARSENATE OF LEAD MIXTURE (Dry Powdered). A combined Fungicide and Insecticide. For Apple and Pear Trees, Potatoes, Melons and Cucumbers: also splendid for roses, keeping them free of mildew. black spot and insects of all sorts. Lb. 50 cts.; 5 lbs. \$2.25; 10 lbs. $\$ 4.00 ; 25$ lbs. $\$ 9.00 ; 50$ lbs. $\$ 17.00 ; 100$ lbs. $\$ 33$.

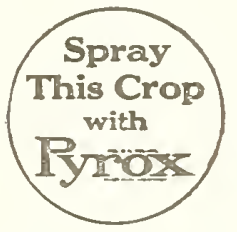

PYROX. An Insecticide and Fungicide. Apple growers swear by this; potato growers make larger crops by its use. It does not wash off as do other poisons. It guards against all chewing insects and prerents rots and blights. Lb. 40 cts.; 5 lbs. $\$ 1.50$; 10 lbs. $\$ 2.50 ; 25$ lbs. $\$ 6.00 ; 50$ lbs. $\$ 10.50 ; 100$ lbs. $\$ 20.00$.

WHALE OIL SOAP. Dissolved in water makes an excellent spray for scale on palms, etc. $1 / 4$ lb. $10 \mathrm{cts}$.; $1 / 2=1 \mathbf{b}$. pkg. 15 cts.; 1=lb. pkg. 35 cts.; 5 lbs. $\$ 1.50 ; 10$ lbs. $\$ 2.40$.
GRAFTING WAX. Used for grafting trees and other plants. $1 / 4$ lb. 15 cts.; I/2 lb. 20 cts.; lb. 30 cts.

FLOUR AND FLOWERS OF SULPHUR. Per lb. $10 \mathrm{cts}$.; 10 lbs. 60 cts.; 25 lbs. $\$ 1.25 ; 100$ lbs. $\$ 4.00$.

\section{"Black Leaf 40"}

\section{Nicotine Sulphur-40 per cent Nicotine.}

This is the insecticide that is so highly recommended by Experiment Stations. It destroys Aphis (plant lice), Thrips, Leaf-hoppers on all tree, bush and vine fruits, vegetables, field crops, flowers and shrubs; also Apple Red Bug, Pear Psylla and similar soft-bodied sucking insectsall without injury to foliage.

It mas be combined with other sprays. Highly concentrated. Soluble in watereasy to mix--does not clog nozzles.

You cannot go wrong by ordering "Black Leaf $40^{\prime}$ for sucking insects.

\section{Prices:}

1 oz........\$ .25-5 gallons spray.

$1 / 2$ lb............. 1.25 - 40 to 120 gals.

10 lbs........ 15.50-800 to 1250 gals.

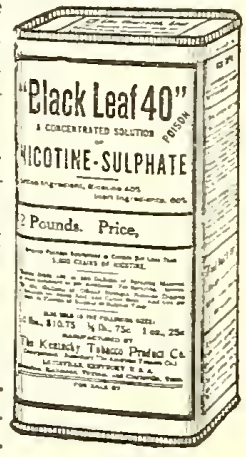

WEED KILLER is especially adapted for destroying weeds in walks, dirt tennis courts, golf links, etc., or any other place where the killing of all regetation is desired. It is successful against all kinds of weeds and grass, incliding milkweed, witchgrass, wild morning glory, dandelions, poison iry, sumach, etc. One application will kill roots and foliage in 48 hours and no more weeds will grow until more seed is sown. $\mathbf{1}=\mathrm{lb}$. pkg. 50 cts., mailing weight, 2 lbs.; $\mathbf{5}=\mathrm{lb}$. pkg. $\$ 2.00$, mailing weight 6 lbs. Special prices on bulk lots to large estates, cemeteries, etc.

CUT WORM KILLER. One of the necessities of the market and home gardener. Cut Worms do so much damage each rear that it amounts to more than a million dollars. $1=l b$. Sprinkler Top boxes, $30 \mathrm{cts}$; $\mathbf{5}=1 \mathrm{~b}$. Tin Cans, contain= ing Sprinkler Top box, $\$ 1.25$ each; 25=1b. Drums, contain= ing Sprinkler Top box, $\$ 5.00$.

RAT KILLER. If we could but realize the destruction caused by rats and mice in each vear, it mould amount to such an enormous amount that we wonld at once begin to kill these pests. Millions of dollars wonld not cover it. Now with the paste we offer sou can rid sour place of both of these vermin. Box, 25 cts.

SHEEP DIP. For Ticks, Lice and Scab. This is a coal tar creosote dip. It is a concentrated fluid for preparing an effectire and economical dip for ridding sheep of ticks, lice and scab: also kills certain fleas, lice and gnats on horses, cattle and hogs. One gallon makes 56 gallons of strong dip by mixing with water. 1=qt. can, 75 cts., mailing weight 4 lbs.: $1 / 2=$ gal. can, $\$ 1.25$, mailing weight 7 lbs.; 1 =gal. can, $\$ 2.00$, mailing $\pi$ eight 11 lbs.; $\mathbf{5}=$ gal. jacket cans, $\$ 9.00$.

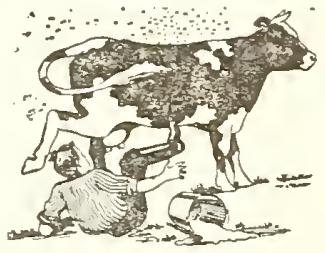

SO=BOS=SO. Use it and milk in comfort-the stuff that lieeps off the fly and mosquito. Few things thele a $r$ e that do as much to reliere the farm animals as this. It sares feed, helps cows

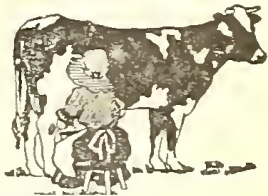
to produce more milk and at the same time saves the nerves of the milkers. We recommend this preparation highly. Price: 1 qt. 50 cts.; $1 / 2$ gal. 75 cts.; gallon, $\$ 1.50$. 


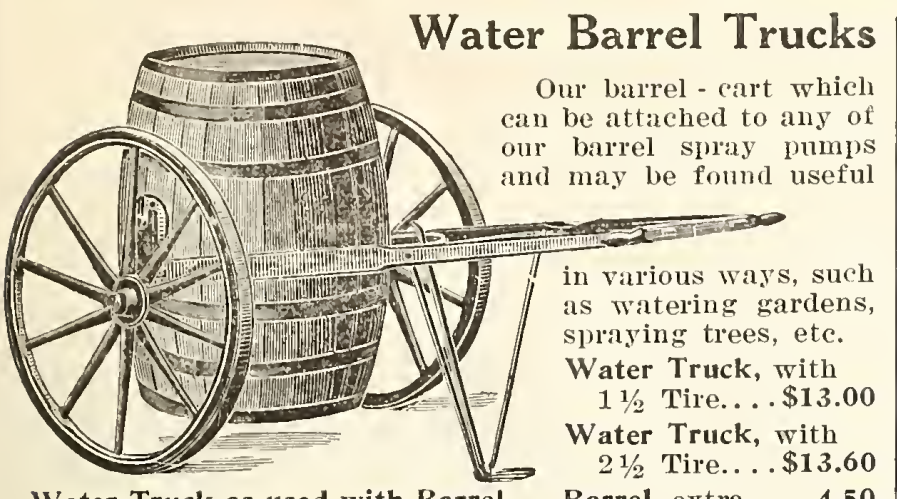

Water Truck as used with Barrel.

Barrel, extra. .

4.50

\section{Spray Pumps}

BRASS BUCKET PU M P ATTACHMENT, ETC., with $\delta$ feet of $3 / \mathrm{s}$-inch Discharge Hose and Seneca Spray Nozzle. Price, \$5.50.

“P O MO NA" SPRAY PUMP with Agitator. All working parts bronze. No leather packing. All valves are bras s; is easily accessible; wing guided on leveled seats ground to fit. Air charmbel steel. Lever $10 \mathrm{n} \mathrm{g}$ and powerful, with adjustable stroke, 3,4 or 5 -inch. Solid brass plunger, machine-turned, fitting gland accurately. Pump is held securely by adjustable clamp plate, made to fit either end or side of barrel, and by a small anchor located at bottom

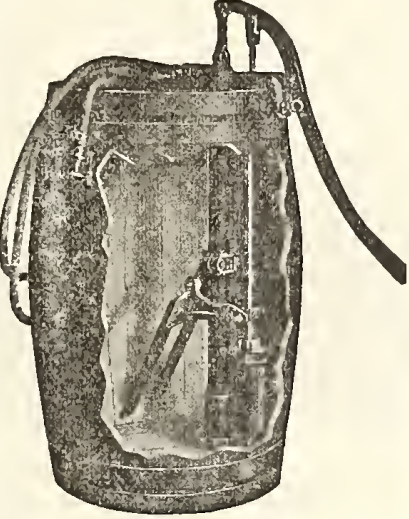

"Pomona" Spray Pump. of barrel. The mechanical agitator is operated by stroke of the handle. Directions sent with each pump.

"FRUITALL" SPRAY PUMP. With Agitator. All working parts bronze. "Fruitall" Spray Pump is made on the same general lines as our famous "Pomona." It is, however, lighter and of smaller capacity. All working parts, including plunger, gland, valves, valve seats and strainer, are of bronze. Regularly fitted with wing agitator, similar to one used on the "Pomona," and which has proven to be the best type. Pump is held in barrel by anchor at bottom and adjustable clamp at top, fitting over end of stave. Not made for side of barrel.

Pomona Spray Pumps, complete with hose, barrel and nozzles.......\$30.00

Fruitall Spray Pumps, complete with

hose, barrel and nozzles........22.00

If wanted without barrel, take from

above prices............. $\mathbf{5 . 0 0}$

THE AUTO SPRAY. Eight to ten strokes of the plunger in air chamber will compress enough air to discharge the entire contents and make a continuous spray for nine minutes. The "Auto Pop" is an automatic valve which is closed by the air pressure used to operate the "Auto Spray.' In operation a lever is moved by simply closing the hand, thus opening the valve and allowing an instantaneous discharge of spray. Price, Gal-

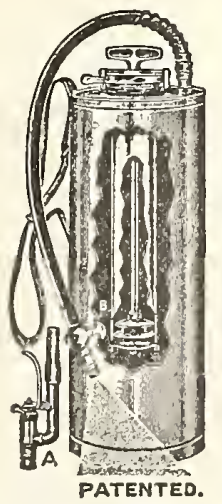
vanized Iron Reservoir, \$6.00; with Auto Pop, \$6.50; Solid Brass Reservoir, \$9.00; with Auto Pop, \$9.50. Extension Rods, 2 -foot lengths, 50 cts.

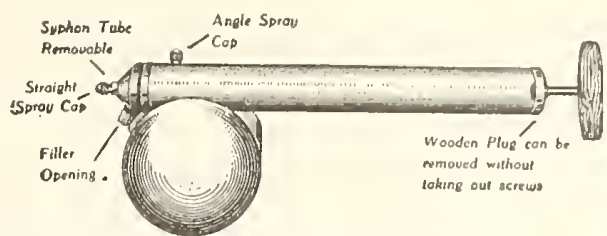

TIN SPRAYERS. IEvery one who raises chicken, knows how important it is to keep out vermin. Use
a spray and the work is done. The illustration is of a spray that will do the work well and cheap. Price, 50 cts.

BRASS AUTOMATIC SPRAYERS. $1=q \mathrm{t}$. , gal= vanized iron, $\$ 1.00 ; 1=q$ t., brass, $\$ 1.35 ; 2$ qts. brass, $\$ 1.75$.

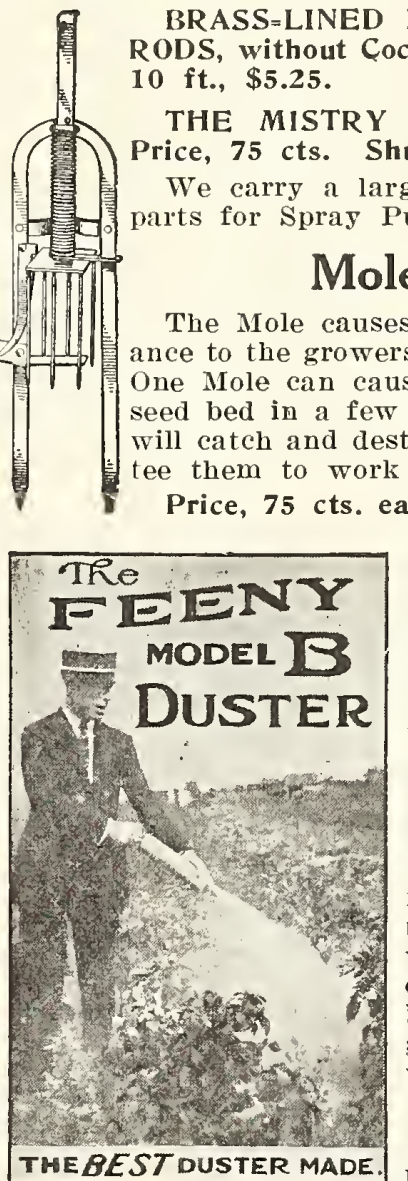

BRASS=LINED BAMBOO EXTENSION ODS, without Cocks. Price, $8 \mathrm{ft}$., $\$ 4.25$;

JR. SPRAY NOZZLE. hut=0ff Cock, $\$ 1.50$. y Pumps and Attachments.

\section{Mole Traps}

great loss and annoywers and market gardeners. cause the loss of an entire them satisfactorily.

FEENEY'S MODEL B DUSTER. Every garden should be provided with either a bellows or a duster for dusting dry powders to destroy Bugs and Fungus growths. In the Feeney's Dust Powder Duster we have found one that is far superior to the bellows in that it makes a much finer dust and spreads the same more evenly and does the work with less effort on the part of the operator. We endorse this Duster believing that in doing it we are giving our trade something that will give them satisfaction.

Price, 90 cts.

T R E E TANGLEFOOT. For protecting trees against climbing insect pests in a simple economi-

cal and effective way. Tree Tanglefoot, sticky substance applied directly to the bark of the tree. One application remains sticky on the trees for 3 months fully exposed to $\mathrm{th} \mathrm{h}$ weather. It is easily applied with a nll wooden paddle. $r a \mathrm{e}$ pound will spread $S$ feet long by 5 inches wide, 1-16 inch thick. Prices: $1=1 b$. can, 50 cts.; 5=lb. can, \$2.25; $10=$ lb. can, $\$ 4.25 ; 20$ lbs. $\$ 8.50 ; 25$ lbs. $\$ 10.00$.

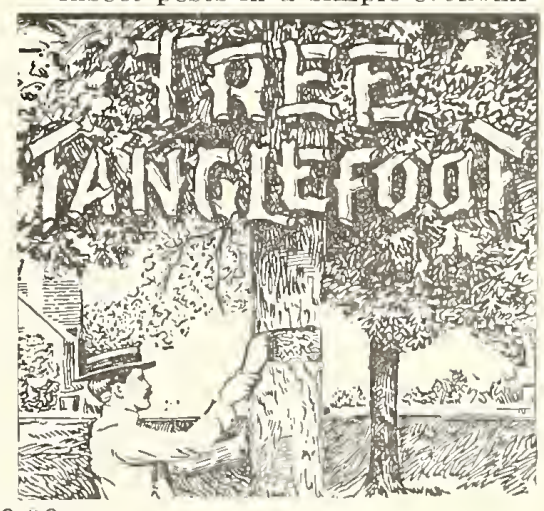

ALL PRICES SUBJECT TO CHANGE WITHOUT NO'TICE 


\section{Capitol Park Lawn Grass Seed}

IT NEVER FAILS TO GIVE SATISFACTION

A lawn may be made in two ways, by sodding or by sowing seed. Sodding is not only ver $y$ expensire but unsatisfactors as well. s o d s are ordinaril taken from the pastur or along the roadside and almost invariably contain weed seeds and coarse tufty grasses which make their appearance after the lawn is made. Seeding is not only cheaper but is attended with better results. The most im portant thing to consider in selecting seed for lawn grass is to obtain a proper mixture of several valieties. Each rariety is at its best during a certain part of the season. By properly choosing earls, medium and late grasses, a smooth, eren, g r e e n lawn is assured from early spring to late autumn.

With these facts i mind, our Capitol Parli Lawn Grass Seed is scientifically combined. Our experience of mans years has given us an intimate knowledge of grasses, their habits and lequirements. In our Capitol Park Green Lawn Grass Seed are included only the rers best rarieties-pure. clean and free from foul seeds.

This grass seed has helped make Washington the beau-

\section{Shady Nook Lawn Grass}

\section{THE GRASS THAT WILL GROW IN SHADY PLACES}

Usuall 5 it is quite difficult to obtain a satisfactory growth of grass under trees and in shady places. For sowing in such places we recommend the use of this special mixture. It will quickly produce an abundant and eren growth of beautiful green grass. The grasses used in making this special mixture are only those that are well adapted for growing in shade.

The fame of this splendid mixture is second only to that of the Capitol Park Mixture.

A trial of this wonderful seed never fails to make a fast friend. By sowing it in the shads spots and our CAPITOL PARK GRASS SEED in the sunns lawns your dreams of a fair relrets green will be quickly realized.

Pkt. 10 cts.; lb. 35 cts.; 25 lbs. $\$ 8.00$.

Parcel Post Rate, page 2. Prices not postpaid.

\section{The "Ideal" Power Lawn Mower}

Shown above at work in the Botanical Gardens at Washington.

\section{For Public and Private Grounds}

Ideal Mowers insure relrety lawns the clean, sure, easy war. Lamns are liept in perfect condition-the work is done quickly and easily by one man and at a minimum expense.

The mower can be guided closels around flower beds, trees and walks. The roller lerels all unsightly bumps, and does not mar the lawn with hoof-prints or mutilate the shrubbery, as is the case with horse-drawn mowers.

Ideal Mowers are a mones-saring investment. Thes do way with several men and horses, and consume gas and oil only while working.

\section{For Golf Grounds}

Maximum enjogment of golf calls for smooth, closecropped putting greens and a neat. trim fairway.

For keeping golf courses in prime condition, the Ideal Power Lawn Mower has no equal-the fairway is cut with the regular 30 -inch cutting blade- $-\pi$ hile the putting greens are kept in trim with a 22 -inch cutting unit designed especially for this purpose.

One man and an "Ideal" can in one day mow all the putting greens of an 18-hole course-and do it better than by any other method.

Price: IdeaI, 30=inch Cut ..........\$325.00 Ideal Jr., 22=inch Cut. . . . . . . . 210.00 


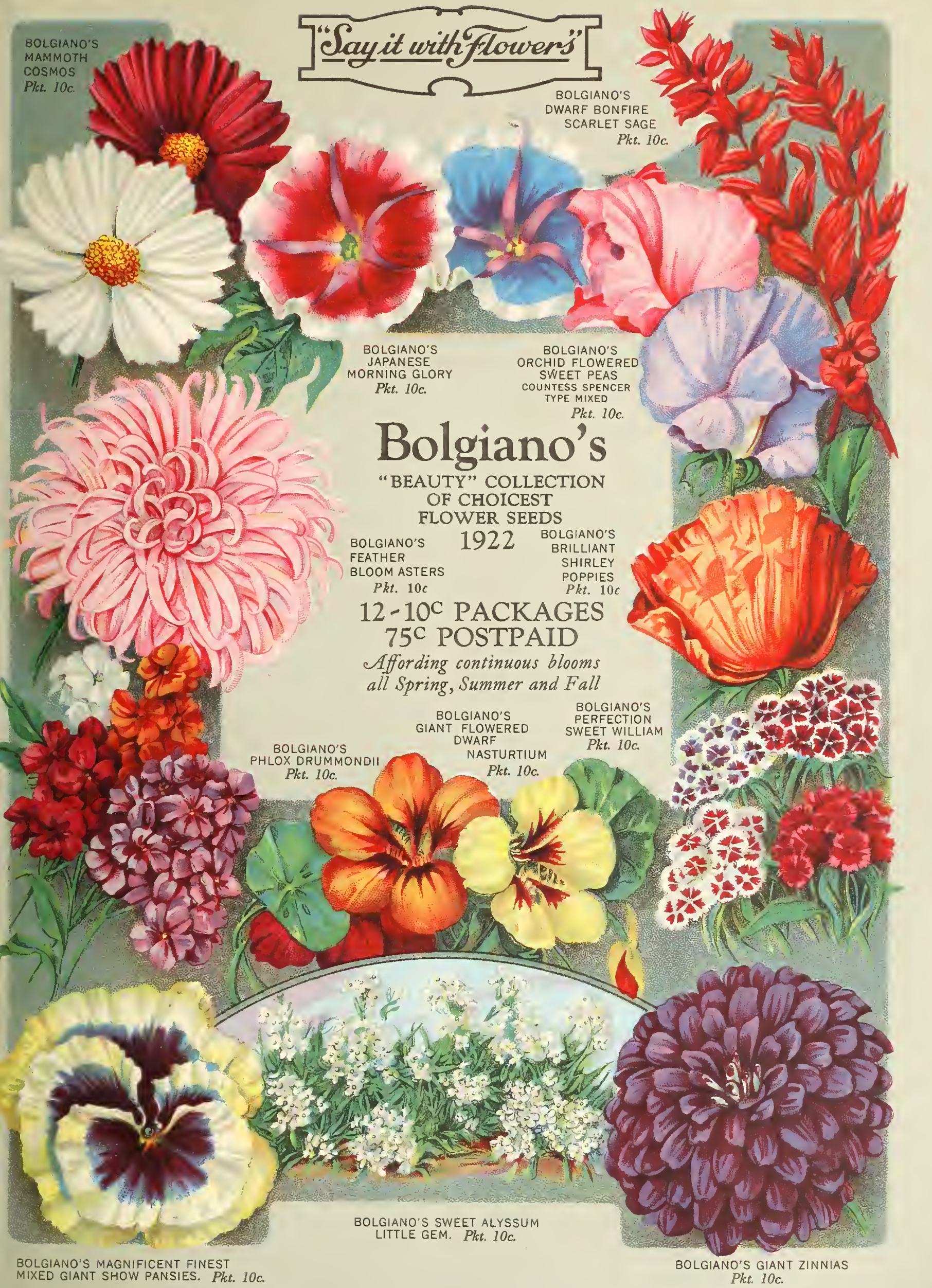


